


\section{DE BIOLOGISCHE KWALITEIT VAN WATERLOPEN, KANAAL EN VIJVERS IN HET BRUSSELS HOOFDSTEDELIJK GEWEST IN 2016}

FYTOPLANKTON, FYTOBENTHOS, MACROFYTEN, MACRO-INVERTEBRATEN \& VISSEN

STIJN VAN ONSEM, JAN BREINE \& LUDWIG TRIEST

FEB. 2017

Onderzoek uitgevoerd door Vrije Universiteit Brussel en Instituut voor Natuur- en Bosonderzoek in opdracht van Leefmilieu Brussel - Brussels Instituut voor Milieubeheer.

INBO.R.2017.12625035

D/2017/3241/006 - DOI 10.21436/inbor.12625035

Dankwoord:

VUB: Onze dank gaat uit naar Luk Van Onsem en Iris Stiers voor essentiële hulp bij het veldwerk. INBO: Het visbestand in de waterlopen van het Brussels Hoofdstedelijk Gewest bemonsteren is zwaar en intensief werk. Maar dat weerhield onze enthousiaste arbeiders en technici niet om de campagnes met succes uit te voeren. Dank je wel Danny Bombaerts, Adinda De Bruyn, Jean-Pierre Croonen, Franky Dens, Nico De Maerteleire, Marc Dewit, Emelie Gelaude, Linde Galle, Isabel Lambeens, Yves Maes en Karen Robberechts. 



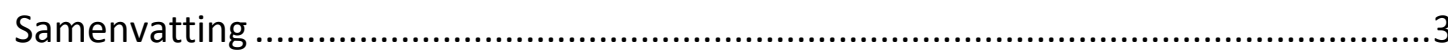

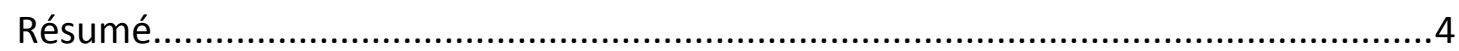

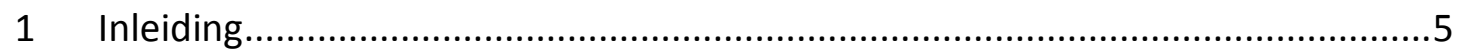

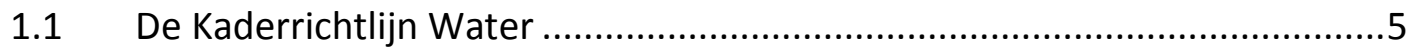

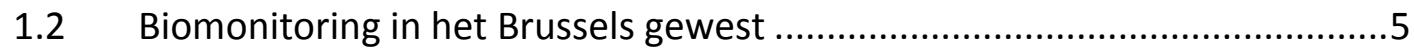

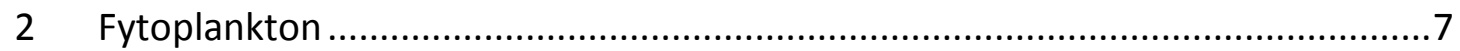

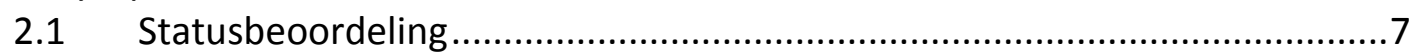

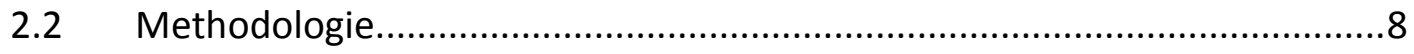

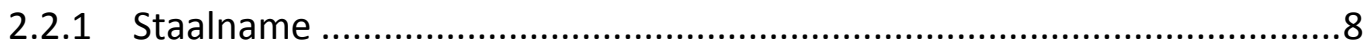

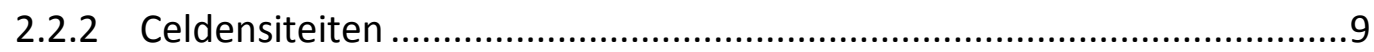

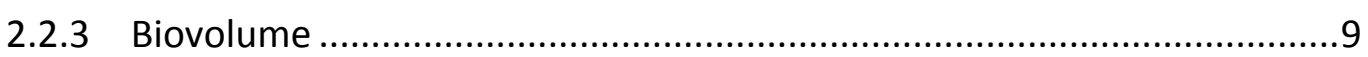

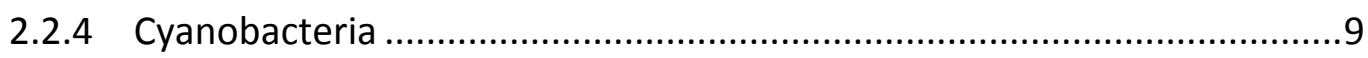

2.2.5 Trofische status van vijvers en kanaal ...............................................10

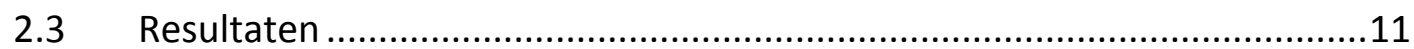

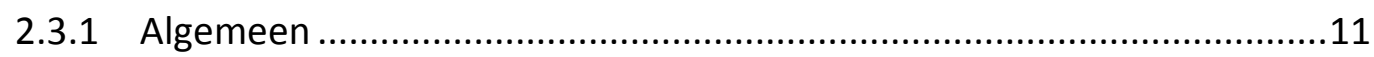

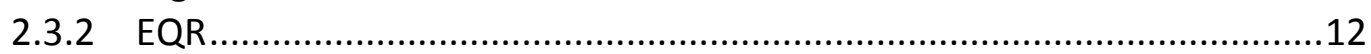

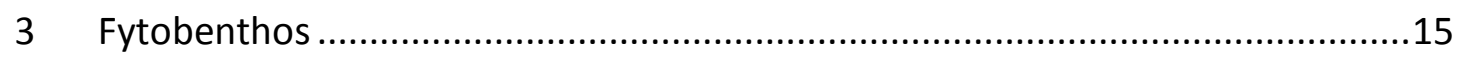

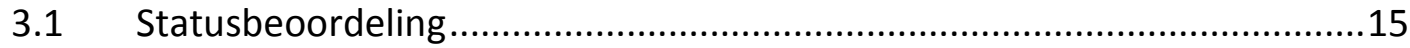

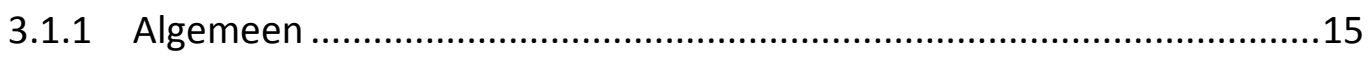

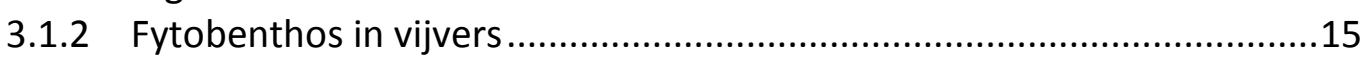

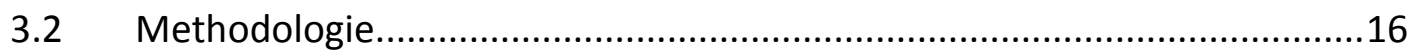

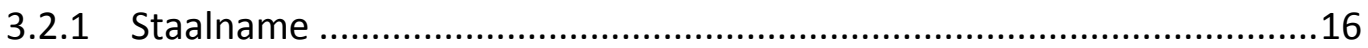

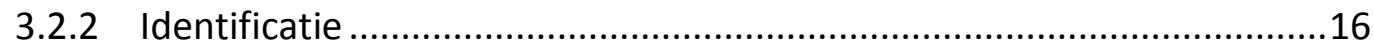

3.2.3 Gemeenschapsanalyse...............................................................16

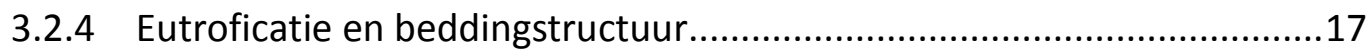

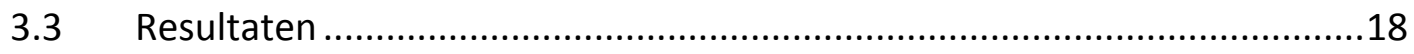

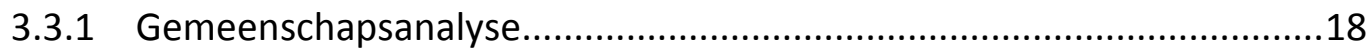

3.3.2 Eutroficatie en beddingstructuur....................................................19

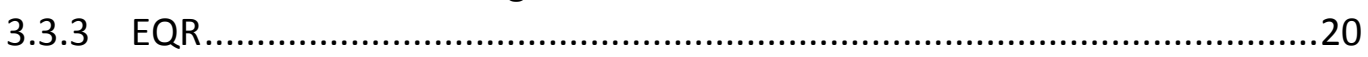

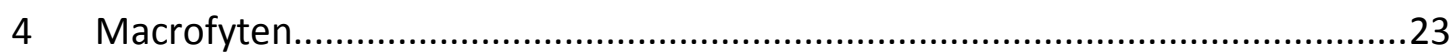

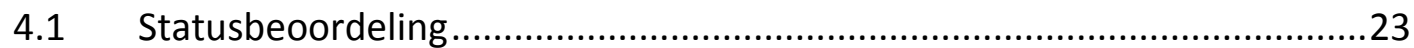

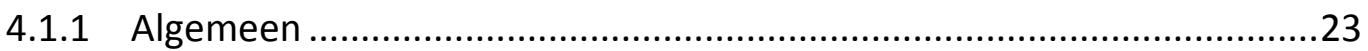

4.1.2 Wijzigingen in beoordeling vijvers ...................................................23

4.1.3 Habitattypes en de Habitatrichtlijn .................................................26

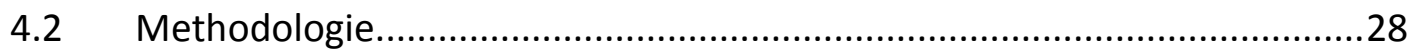

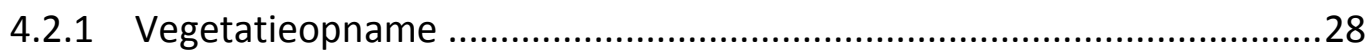

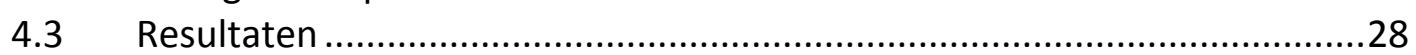

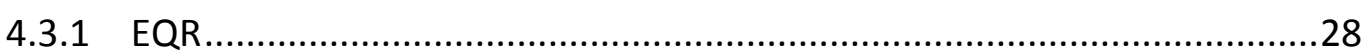

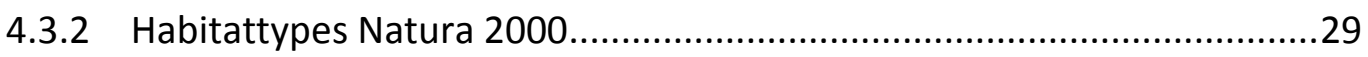

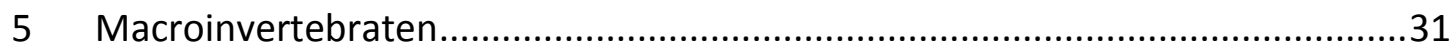

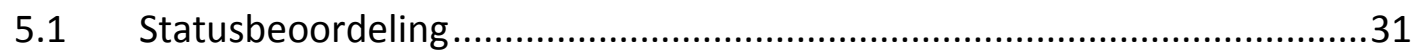

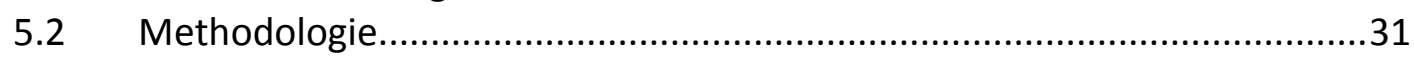

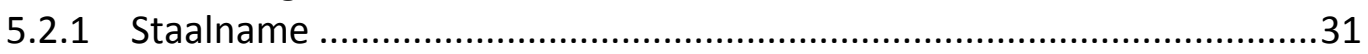

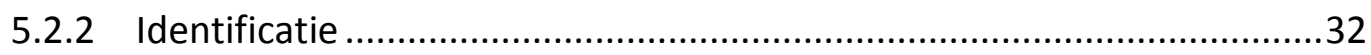

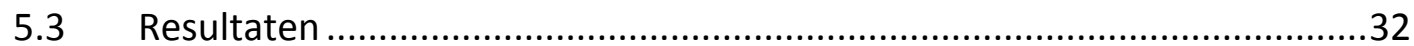

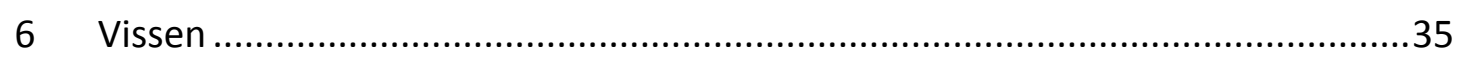

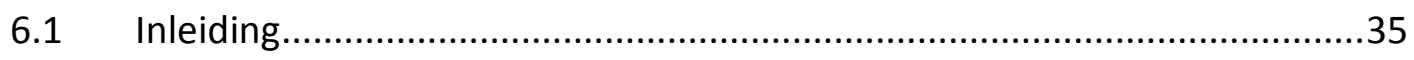




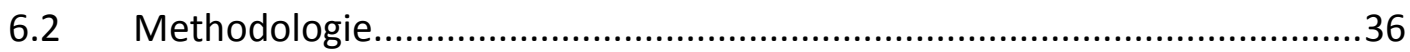

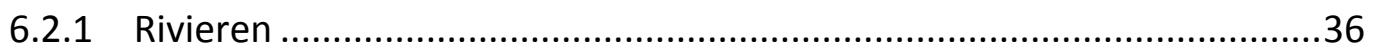

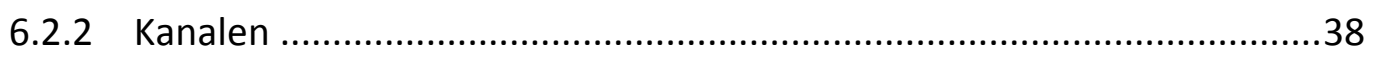

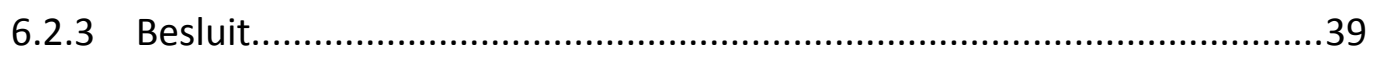

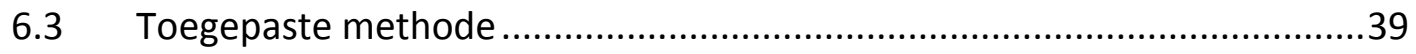

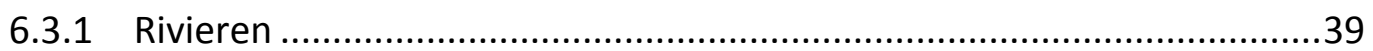

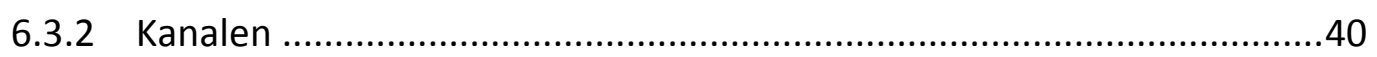

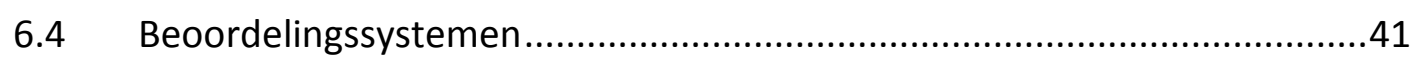

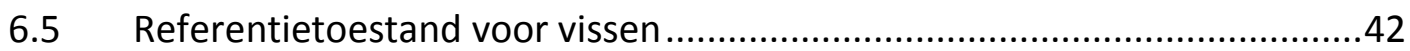

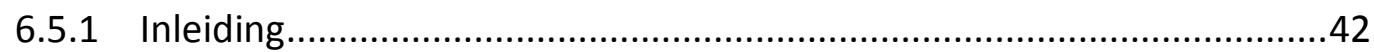

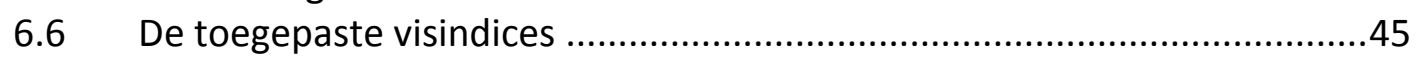

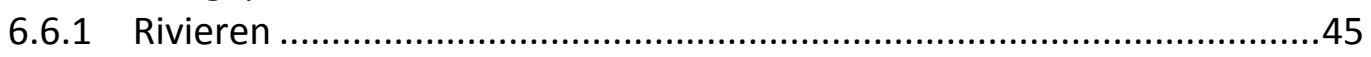

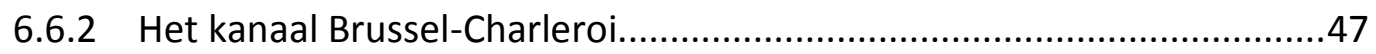

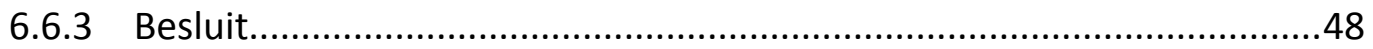

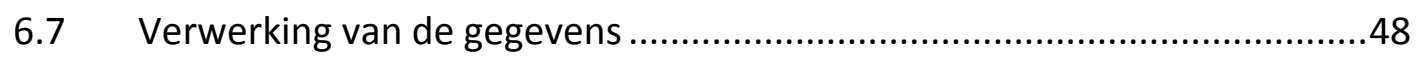

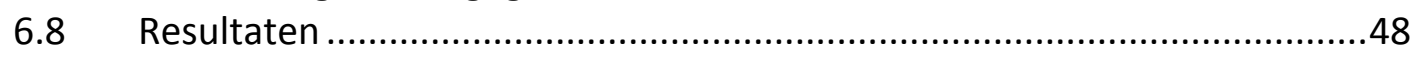

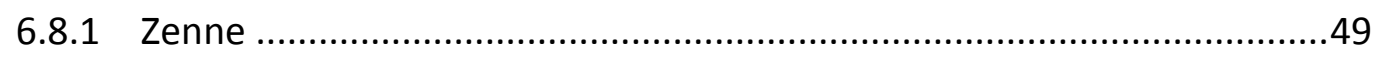

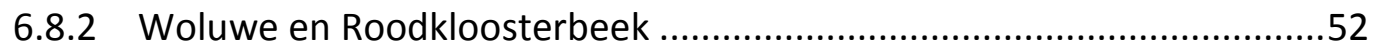

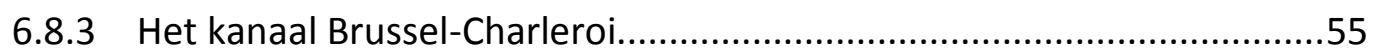

6.9 Overzicht van de beoordeling op basis van de type-specifieke visindices..63

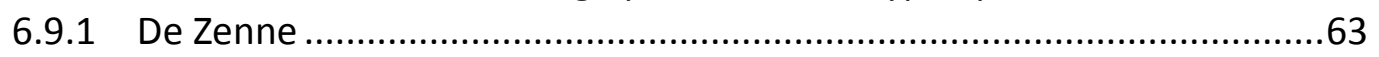

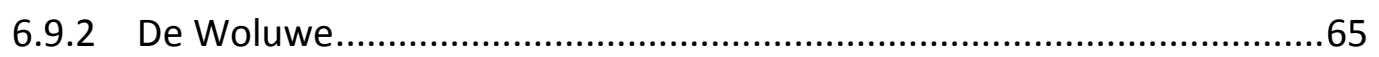

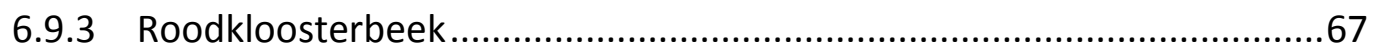

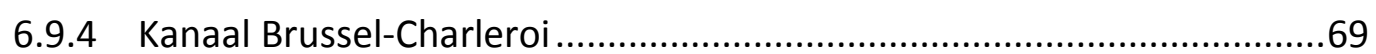

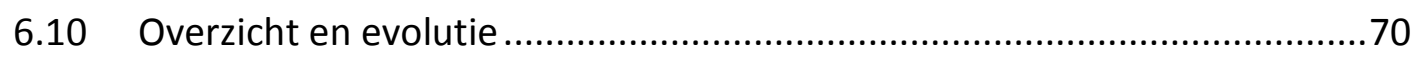

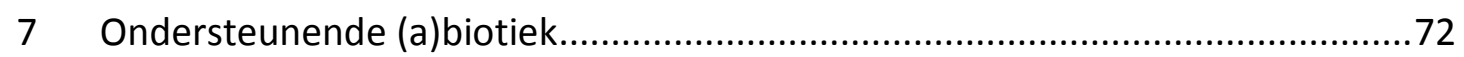

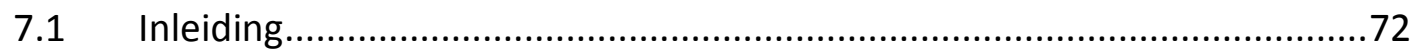

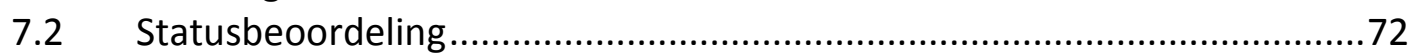

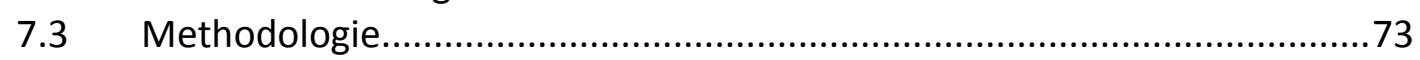

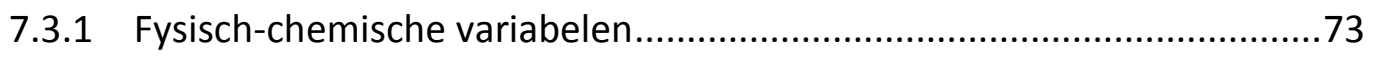

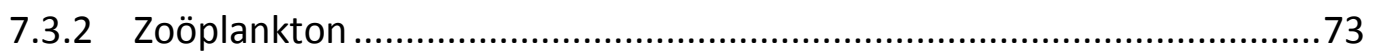

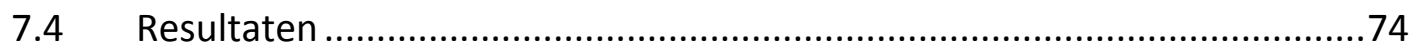

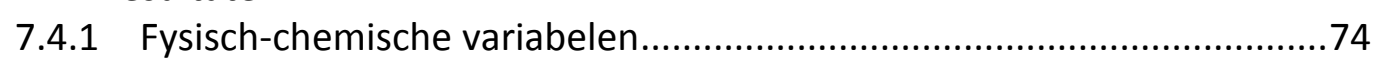

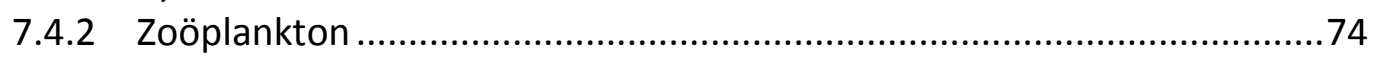

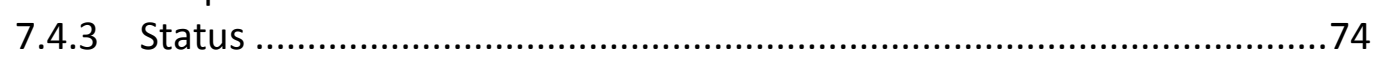

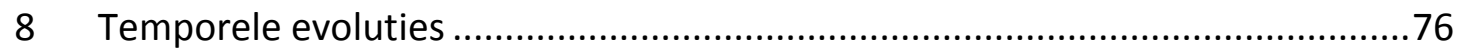

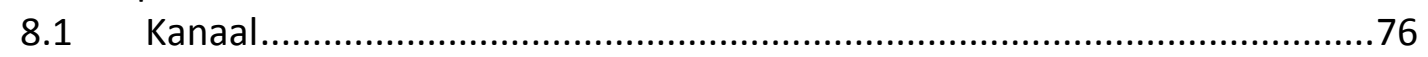

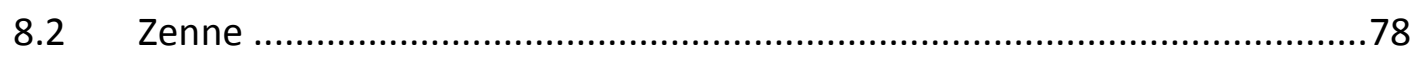

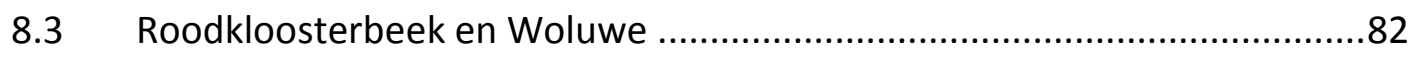

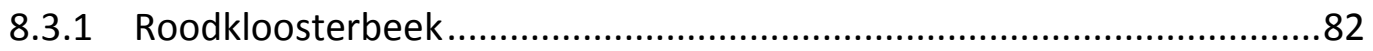

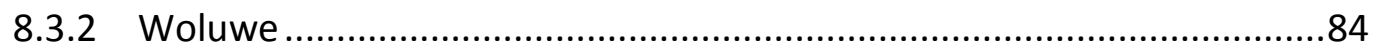

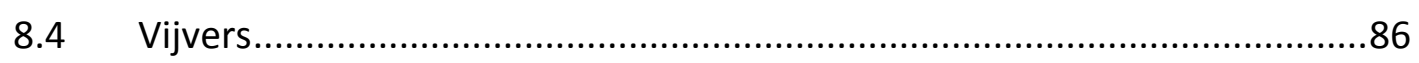

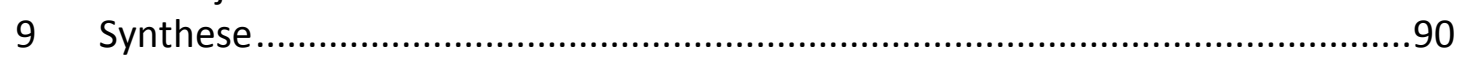

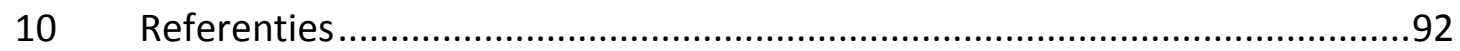

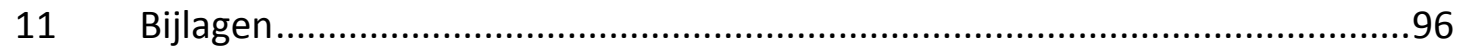




\section{Samenvatting}

De Kaderrichtlijn Water betekende een sterke en noodzakelijke impuls om op schaal van de Europese Unie de oppervlaktewaterstatus te verbeteren en te behoeden voor verdere achteruitgang. Dit rapport beschrijft de resultaten van de biologische monitoring van vijf aquatische organismegroepen in het Brussels Hoofdstedelijk Gewest in 2016, in de oppervlaktewaterlichamen Zenne, kanaal en Woluwe. Aanvullend werden net als in voorgaande campagnes ook de Roodkloosterbeek en drie vijvers gemonitord.

De opvolging van fytobenthos, fytoplankton, macrofyten, macro-invertebraten en vis vormt een verplicht onderdeel van de ecologische statusbeoordeling opgelegd door de Kaderrichtlijn Water, en vult de ecologische evaluatie op basis van fysischchemische en hydromorfologische kenmerken en concentraties van specifieke verontreinigende stoffen aan.

Net als in 2013 werd in 2016 op geen enkele locatie het Goed Ecologisch Potentieel (GEP) bereikt, omdat steeds voor één of meerdere biologische kwaliteitselementen een minder dan goede toestand werd vastgesteld.

- In de Zenne verbeterde de kwaliteit voor fytobenthos, en zijn er signalen van een voorzichtig maar opmerkelijk herstel van de visgemeenschap. De positieve trend voor de Zenne sinds 2004 is statistisch significant, maar blijft onvoldoende om op korte termijn de Europese doelstellingen te behalen.

- Het kanaal Charleroi-Brussel-Schelde bevindt zich in het Brussels gewest globaal gezien in matige toestand, ondanks een goede toestand voor fytoplankton. Het kanaal bevat een groot aantal invasieve exoten, maar hun impact op het GEP is nog onvoldoende duidelijk.

- In de Woluwe bleef de globale kwaliteit ontoereikend door het ontbreken van een aantal typespecifieke vissoorten. Ten opzichte van voorgaande campagnes werd een daling van de kwaliteit op het vlak van fytobenthos en macro-invertebraten waargenomen. De gedeeltelijke ecologische terugval zou het gevolg kunnen zijn van slechte weersomstandigheden, hoewel er ook elementen zijn die zouden kunnen wijzen op een meer structurele, en dus zorgwekkende, oorzaak. Dit moet verder onderzocht worden.

- De hydromorfologische kwaliteit van de Roodkloosterbeek blijft ongunstig voor de groei van macrofyten en ontwikkeling van een diverse visgemeenschap. Hermeandering of heraanleg van de oevers is hier zeker aangewezen.

- Het contrast tussen de drie opgevolgde vijvers is groot. De visvijver Ter Bronnen blijft vrij troebel en ongeschikt voor macrofyten. In de lange vijver van het Woluwepark is de situatie veel beter (H3150 volgens de Habitatrichtlijn), dankzij een helderwatertoestand met dominantie van submerse macrofyten. De grote Watermaalvijver werd recent gebiomanipuleerd en vertoont signalen van herstel, hoewel het water in 2016 vrij troebel bleef en submerse aquatische vegetatie nog onvoldoende abundant voorkwam. 
La Directive-cadre sur l'Eau signifiait un stimulant fort et essentiel afin d'améliorer, à l'échelle de l'Union européenne, l'état des eaux de surface, et de les protéger contre la dégradation. Ce rapport décrit les résultats de la surveillance biologique de cinq groupes d'organismes aquatiques dans la Région de Bruxelles-Capitale en 2016, dans les masses d'eau de surface de la Senne, le canal et la Woluwe. En complément, comme dans les campagnes précédentes, le Ruisseau du Rouge Cloître ainsi que trois étangs ont été surveillés.

Le suivi du phytobenthos, du phytoplancton, des macrophytes, des macroinvertébrés et des poissons est une obligation imposée par la Directive-cadre sur l'Eau, et complète la surveillance écologique sur base des caractéristiques physicochimiques, hydromorphologiques et des concentrations de polluants spécifiques.

Comme en 2013, aucun des sites de contrôle n'atteignait le Bon Potentiel Ecologique (GEP) en 2016, car un ou plusieurs éléments de qualité biologique n'atteignent pas le bon potentiel.

- Dans la Senne, la qualité pour l'élément phytobenthos a augmenté, et il y a des signes d'une légère amélioration très remarquée des poissons. La tendance positive dans la Senne depuis 2004 est également statistiquement significative, mais reste toutefois insuffisante en vue de l'atteinte des objectifs européens à court terme.

- La partie du canal Charleroi-Bruxelles-Escaut située dans la région bruxelloise se trouve globalement dans un état médiocre, malgré une bonne situation pour le phytoplancton. Le canal contient un grand nombre d'espèces exotiques invasives, mais leur impact sur le GEP n'est pas encore bien connu.

- Dans la Woluwe, la qualité globale reste insuffisante à cause de l'absence de certains poissons typiques. Par rapport aux campagnes précédentes, une diminution de la qualité des phytobenthos et des macroinvertébrés a également été observée. Le déclin écologique partiel pourrait être dû à des conditions climatologiques non favorables, bien qu'il pourrait également être provoqué par une dégradation plus structurelle et donc, inquiétante. Ceci est à investiguer.

- La situation hydromorphologique du Ruisseau du Rouge Cloître reste défavorable pour les macrophytes et au développement d'une communauté de poissons diversifiée. La reconstruction des méandres ou de la structure des berges serait très intéressante à réaliser.

- Le contraste entre les trois étangs suivis est important. L'étang de pêche dans le Parc des Sources reste assez trouble et non favorable aux macrophytes. Dans le long étang du Parc de Woluwe, la situation est bien meilleure (H3150 selon la Directive Habitats), grâce à l'eau claire et une dominance des macrophytes submergés. Le grand étang Watermael a récemment été biomanipulé et montre des signes d'amélioration écologique, bien que l'eau reste assez trouble en 2016 et la végétation aquatique submergée n'était pas encore suffisamment abondante. 


\section{$1 \quad$ Inleiding}

\section{De Kaderrichtlijn Water}

De Europese Kaderrichtlijn Water (KRW; EC 2000) is ongetwijfeld een van de meest ambitieuze en verstrekkende regelgevingen op gebied van het herstel en behoud van natuurlijk patrimonium in de Europese Unie. Samen met doelstellingen van de Habitatrichtlijn (HRL; EEC 1992) die betrekking hebben op het aquatische milieu, betekende de Kaderrichtlijn een sterke en noodzakelijke impuls om de status van oppervlaktewateren te verbeteren of ze te behoeden voor degradatie.

De KRW werd opgenomen in de legislatie van het Brussels Hoofdstedelijk Gewest via de Ordonnantie Water (2006). Concrete objectieven en maatregelenprogramma's werden hernieuwd in het tweede Waterbeheerplan (cyclus 2016-2021; BIM 2015). Aangezien de doelstelling om in Zenne, kanaal en Woluwe een Goed Ecologisch Potentieel (GEP) te halen onmogelijk konden bereikt worden in de aanloop naar 2015, wordt voor de verschillende waterlichamen gefaseerd toegewerkt naar meer realistische eindtermijnen. Biologische monitoring of biomonitoring van het aquatische leven blijft daarbij de ruggengraat van de ecologische statusbeoordeling.

\subsection{Biomonitoring in het Brussels gewest}

De organismegroepen die opgevolgd worden in functie van de KRW worden aangegeven in Tabel 1.

Tabel 1: Biologische kwaliteitselementen onderzocht in de verschillende types waterlichamen. Nvt: niet van toepassing.

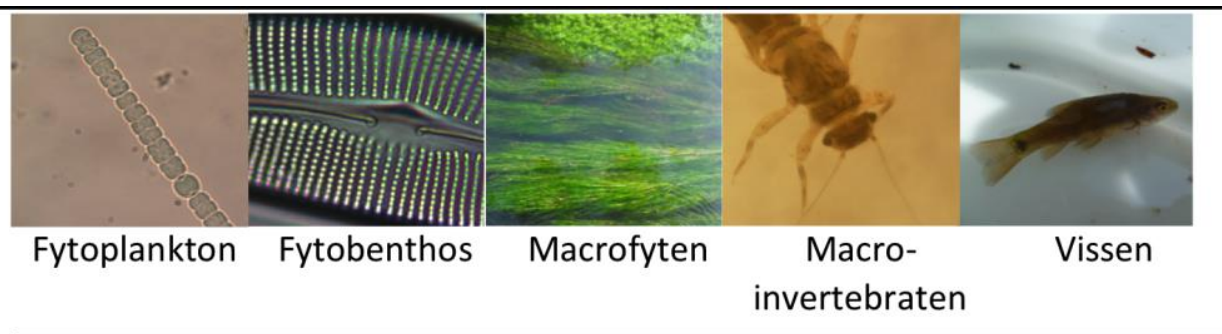

$\begin{array}{lllll}\text { Waterlopen } & \text { nvt } & \text { x } & \text { x } & \text { x } \\ \text { Kanaal } & \mathrm{x} & \mathrm{x} & \mathrm{nvt} & \mathrm{x} \\ \text { Vijvers } & \mathrm{x} & \mathrm{x} & \mathrm{x} & \mathrm{x} \\ \end{array}$

De voor een beperkte oppervlakte grote diversiteit aan types waterlichamen die opgevolgd worden in het Brussels Hoofdstedelijk Gewest (Tabel 2), zorgt ervoor dat de bemonstering en beoordeling sterk uiteenlopend gebeuren. Op locaties die moeilijk toegankelijk zijn en waar de bedding slecht bereikbaar is, wordt voor de 
opname van benthische organismen (fytobenthos en macroinvertebraten) bijvoorbeeld met artificiële, uitgehangen substraten gewerkt. Ook voor vis wordt niet op elke plaats op dezelfde manier bemonsterd.

Tabel 2: Staalnamelocaties in Zenne, kanaal en Woluwebekken, en hun codering.

\begin{tabular}{|c|c|c|c|c|}
\hline Categorie & Code VUB & Code BIM & Naam & Gemeente - Straat \\
\hline Waterloop & RK & ROO001 & Roodkloosterbeek (Bergojepark) & Oudergem - Jacques Bassemstraat \\
\hline Waterloop & S1 & ZEN025 & Zenne voor RWZI Zuid & Anderlecht - Internationalelaan \\
\hline Waterloop & S2 & ZEN025 (vis) & Zenne na RWZI Zuid & Anderlecht - Bollinkxstraat \\
\hline Waterloop & S4 & ZEN070 & Zenne na RWZI Noord & Brussel - Budasesteenweg \\
\hline Waterloop & W2 & WOL025 & Woluwe (Hof ter Musschen) & Sint-Lambrechts-Woluwe - Woluwelaan \\
\hline Kanaal & $\mathrm{C} 1$ & KAN005 & Kanaal IN & Anderlecht - Aakaai \\
\hline Kanaal & $\mathrm{C} 2$ & KAN050 & Kanaal UIT & Brussel - Vilvoordsesteenweg \\
\hline Vijver & $\mathrm{TrBr}$ & ETA223 & Ter Bronnen & Sint-Lambrechts-Woluwe - Woluwelaan \\
\hline Vijver & WPk1 & ETA013 & Woluwepark 1 (lange vijver) & Sint-Pieters-Woluwe - Tervurenlaan \\
\hline Vijver & Wtml & ETA051 & Watermaal & Watermaal-Bosvoorde - Vuursteenweg \\
\hline
\end{tabular}

Het is een uitdaging om voor verschillende types waterlichamen en op basis van alle biologische kwaliteitselementen en variabele meet- en inzamelmethodes een correct en consistent overzicht te genereren van de ecologische kwaliteit van aquatische milieus in het gewest. Om die reden werd in het verleden veel aandacht besteed aan het verfijnen, kalibreren en afstemmen van de operationele methodologie, en wordt steeds ruimte gelaten voor aanpassingen die de kwaliteitsbeoordeling kunnen verbeteren.

Tabel 3 geeft een overzicht van de monitoringsdata en toegepaste methoden voor inzameling en veldopnames.

Tabel 3: Overzicht van staalnamemomenten en methoden. Biologische kwaliteitselementen: FP fytoplankton, FB - fytobenthos, MF - macrofyten, MI - macro-invertebraten, VIS - vissen. Inzamelingstechnieken: AS - artificieel substraat, B - boot, E - elektrische afvissing, F - fuiken, K kicksampling, NS - natuurlijk substraat, $\mathrm{O}$ - oevertransect, $\mathrm{W}$ - transect met waadpak. Nvt - niet van toepassing.

\begin{tabular}{|c|c|c|c|c|c|c|c|c|c|c|c|}
\hline \multicolumn{2}{|l|}{ Locatie } & \multicolumn{2}{|l|}{ FP } & \multicolumn{2}{|l|}{ FB } & \multicolumn{2}{|l|}{ MF } & \multicolumn{2}{|l|}{$\mathrm{MI}$} & \multicolumn{2}{|l|}{ VIS } \\
\hline RK & ROO001 & nvt & & $11 / 05 / 16$ & NS & 05/08/16 & w & $28 / 06 / 16$ & $\mathrm{~K}$ & $09 / 05 / 16+07 / 10 / 16$ & $\mathrm{E}$ \\
\hline S1 & ZEN025 & nvt & & 29/06/16 & AS & 05/08/16 & 0 & $29 / 06 / 16$ & AS & nvt & \\
\hline S2 & ZENO25 (vis) & nvt & & nvt & & nvt & & nvt & & $13 / 06 / 16+25 / 10 / 16$ & $\mathrm{E}$ \\
\hline S4 & ZEN070 & nvt & & $29 / 06 / 16$ & AS & $05 / 08 / 16$ & 0 & $29 / 06 / 16$ & AS & $12 / 05 / 16+13-14 / 06 / 16+25 / 10 / 16$ & $E+F$ \\
\hline W2 & WOL025 & nvt & & $11 / 05 / 16$ & NS & $05 / 08 / 16$ & w & $28 / 06 / 16$ & K & $09 / 05 / 16+07 / 10 / 16$ & $\mathrm{E}$ \\
\hline C1 & KANO05 & $16 / 06 / 16$ & 0 & $29 / 06 / 16$ & AS & nvt & & $29 / 06 / 16$ & AS & $25 / 05 / 16+18-20 / 10 / 16$ & $E+F$ \\
\hline $\mathrm{C} 2$ & KAN050 & $16 / 06 / 16$ & 0 & $29 / 06 / 16$ & AS & nvt & & $29 / 06 / 16$ & AS & $25 / 05 / 16+18-20 / 10 / 16$ & $E+F$ \\
\hline $\mathrm{TrBr}$ & ETA223 & $16 / 06 / 16+05 / 08 / 16$ & 0 & 05/08/16 & AS & $16 / 06 / 16+05 / 08 / 16$ & 0 & $28 / 06 / 16$ & $\mathrm{k}$ & nvt & \\
\hline WPk1 & ETA013 & $16 / 06 / 16+04 / 08 / 16$ & $B$ & $04 / 08 / 16$ & AS & $16 / 06 / 16+04 / 08 / 16$ & $O+B$ & $28 / 06 / 16$ & K & nvt & \\
\hline Wtml & ETA051 & $16 / 06 / 16+04 / 08 / 16$ & B & $04 / 08 / 16$ & AS & $16 / 06 / 16+04 / 08 / 16$ & $O+B$ & $28 / 06 / 16$ & $\mathrm{~K}$ & nvt & \\
\hline
\end{tabular}




\section{Fytoplankton}

\section{Statusbeoordeling}

De beoordelingsmethode voor fytoplankton zoals gebruikt in Van Onsem et al. (2014) werd aangepast zoals voorgesteld voor het bepalen van de EQR voor fytoplankton in vijvers (Tabel 4; Van Onsem \& Triest 2015). Vergeleken met de voorgaande berekeningswijze, werden volgende wijzigingen uitgevoerd:

1. Wegname van de variabele conductiviteit (elektrische geleidbaarheid) omwille van het beperkte verband met fytoplankton. Conductiviteit werd overgebracht naar de set van supplementaire (a)biotische variabelen met een ondersteunende of relevante rol in de algemene ecologische toestand van de stilstaande waterlichamen (zie Hoofdstuk 7).

2. Verfijning van de klassengrenzen voor TP (totaal fosfaat). Het verband tussen TP en abundantie van fytoplankton rechtvaardigt het behoud van deze parameter, zij het na aanpassing van de grenzen in functie van het biomanipulatiesucces (afgemeten op basis van fytoplanktonabundantie) van vijvers in het Brussels Hoofdstedelijk Gewest (De Backer et al. 2014; Van Onsem \& Triest 2015).

3. Verdubbeling van de klassegrenzen voor celdensiteit, als gevolg van een potentieel te strenge evaluatie in het geval van hoge abundanties van picoplankton. De resulterende klassen zorgen voor een correctere differentiatie van de positie van (peri-)urbane vijvers langsheen een turbiditeitsgradiënt, op voorwaarde dat het picoplankton nauwkeurig wordt gekwantificeerd.

4. Aanpassing van de klassengrenzen voor pigmentconcentraties. De grenswaarden voor concentraties van $\mathrm{Chl} a$ en het degradatieproduct feofytine werden gekalibreerd op basis van de Vlaamse methode voor (ondiepe) matig ionenrijke, alkalische meren (VMM 2009) en het ECOFRAMEprotocol voor ondiepe meren (Moss et al. 2003). De initiële indeling (Van Tendeloo et al. 2004) werd verfijnd, maar houdt nog steeds rekening met ecologische beperkingen van recreationele visvijvers of het kanaal.

Hoewel de aangebrachte wijzigingen in hoofdzaak zijn gebaseerd op het functioneren van vijvers in het Brussels Hoofdstedelijk Gewest, werden ze in de huidige studie eveneens voor de beoordeling van fytoplankton in het kanaal toegepast (te valideren). De EQR wordt berekend op basis van de vier weerhouden variabelen. Deelscores worden opgeteld en gedeeld door 20. De klassenindeling volgens Van Onsem et al. (2014) blijft behouden. 
Tabel 4: Beoordelingsmethode voor fytoplankton.

Parameter

1. Totaal fosfaat (TP)

Piekwaarden $>0.74 \mathrm{mg} \mathrm{P} / \mathrm{L}$

Gemiddelde 0.30-0.74 mg P/L

Gemiddelde $<0.30 \mathrm{mg} \mathrm{P} / \mathrm{L}$, maar met piekwaarden $>0.30 \mathrm{mg} \mathrm{P} / \mathrm{L}$

Steeds $<0.30 \mathrm{mg} \mathrm{P} / \mathrm{L}$

2. Fytoplanktonabundantie (incl. picoplankton) (cellen/mL)

Gemiddelde $>40000$ cellen $/ \mathrm{mL}$

Gemiddelde 10000 - 40000 cellen $/ \mathrm{mL}$

Gemiddelde 2000 - 10000 cellen $/ \mathrm{mL}$

Gemiddelde $<2000$ cellen/mL

3. Fytoplanktonabundantie (pigmentconcentratie) vijvers excl. visvijvers of kanaal

$\mathrm{Chl}$ a + feofytine $\geq 120 \mu \mathrm{g} / \mathrm{L}$

$\mathrm{Chl}$ a + feofytine $50-120 \mu \mathrm{g} / \mathrm{L}$

$\mathrm{Chl} \mathrm{a}+$ feofytine $25-50 \mu \mathrm{g} / \mathrm{L}$

$\mathrm{Chl} \mathrm{a}+$ feofytine $10-25 \mu \mathrm{g} / \mathrm{L}$

$\mathrm{Chl}$ a + feofytine $<10 \mu \mathrm{g} / \mathrm{L}$

Kanaal en visvijvers

Chl a + feofytine $\geq 120 \mu \mathrm{g} / \mathrm{L}$

$\mathrm{Chl} \mathrm{a}+$ feofytine $50-120 \mu \mathrm{g} / \mathrm{L}$

Chl a + feofytine 25-50 $\mathrm{\mu g} / \mathrm{L}$

Chl a + feofytine 10-25 $\mathrm{gg} / \mathrm{L}$

$\mathrm{Chl}$ a + feofytine $<10 \mu \mathrm{g} / \mathrm{L}$

4. Cyanobacteriële bloei

Meerdere perioden met cyanobacteriebloei per groeiseizoen (zichtbare pel of $\geq 20000 \mathrm{cellen} / \mathrm{mL}$ ) 0

Eén enkele bloei in groeiseizoen (zichtbare pel of $\geq 20000$ cellen $/ \mathrm{mL}$ ) 1

Geen perioden van bloei, gemiddelde 2000 - 20000 cellen $/ \mathrm{mL} \quad 3$

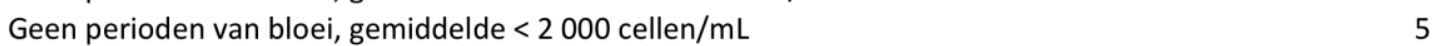

\subsection{Methodologie}

\subsubsection{Staalname}

Waterstalen voor identificatie en kwantificatie van fytoplankton werden ingezameld met behulp van een transparante plastic buis met volume van $1 \mathrm{~L}$ op vijf haltes vanaf de oever (kanaal en $\mathrm{TrBr}$ ) of een boot (WPk1 en Wtml). In totaal werd $10 \mathrm{~L}$ kanaal- of vijverwater verzameld. Substalen van $500 \mathrm{~mL}$ voor telling en identificatie werden gefixeerd met Lugol, natriumthiosulfaat en gebufferde formaline. Voor de bepaling van concentraties $\mathrm{Chl} a$ en feofytine werd een substaal van $1 \mathrm{~L}$ overgebracht naar het laboratorium en onmiddellijk gefiltreerd voor latere pigmentextractie. Ongefilterde waterstalen werden verzameld voor spectrofoto-metrische analyse van TP. 


\subsubsection{Celdensiteiten}

Gefixeerde stalen werden geanalyseerd met de Utermöhl-sedimentatietechniek en een inverse microscoop bij een vergroting van 1000x. Fytoplanktoncellen werden geteld tot het bereiken van minstens 200 teleenheden (individuele cellen, coenobia of kolonies). Er werd een onderscheid gemaakt tussen eukaryote taxa, Cyanobacteria en niet-koloniale picoplanktoncellen (een moeilijk te determineren functionele groep met diameter $<2 \mu \mathrm{m}$, die zowel eukaryote als cyanobacteriële soorten bevat; Reynolds 2006). Voor de complexe koloniale groenalg Volvox wordt een telmethode gehanteerd beschreven in Van Onsem \& Triest (2015), hoewel dit taxon in 2016 niet werd aangetroffen. Celdichtheden werden uitgedrukt als aantal cellen per $\mathrm{mL}$.

\subsubsection{Biovolume}

Hoewel de celdensiteit van fytoplankton relatief efficiënt kan bepaald worden en het een waardevolle parameter betreft, kan de vergelijking met andere sites of historische data vertekend worden in het geval van een grote variatie aan samenstelling binnen de fytoplanktongemeenschap. Een theoretisch meer accurate - hoewel tijdrovende - benadering van de abundantie van fytoplankton is het bepalen van het totale biovolume van cellen en kolonies, zodat aanwezigheid van taxa met grote afmetingen en een sterke impact op de transparantie van het water correct doorweegt in het kwaliteitsoordeel. In Van Onsem \& Triest (2015) werd de relatie tussen celdensiteit en biovolume van fytoplankton in vijvers in het Brussels gewest berekend (spearman $r=0.92 ; p<0.00001 ; n=33$ ). De sterke correlatie is een argument voor het behoud van celdensiteit als deelmaatlat in het protocol voor fytoplankton. In de huidige studie werd biovolume niettemin opnieuw bepaald, onder meer ter controle van het verband tussen beide parameters in het kanaal.

Voor de analyse van het biovolume werden voor elke teleenheid de doorsnede of verschillende dimensies van individuele cellen, kolonies of coenobia gemeten. Voor taxa die geïdentificeerd konden worden tot op genusniveau werden cel- of coenobiadensiteiten geconverteerd naar biovolume met behulp van universele geometrische vormen (Hillebrand et al. 1999; EPA 2010; Vadrucci et al. 2013). Bij een deel van de ongekende taxa konden vormen vereenvoudigd worden tot hetzij sferisch, cilindrisch of overeenstemmend met de geometrie van een prolate spheroïde. Voor Volvox wordt het biovolume van de individuele cellen bepaald na schatting van het aantal cellen in de kolonies (Van Onsem \& Triest 2015). Celdensiteiten werden omgezet naar totaal biovolume en uitgedrukt in $\mathrm{mm}^{3} / \mathrm{L}$.

\subsubsection{Cyanobacteria}

Een complicatie bij het kwantificeren van Cyanobacteria is de aanwezigheid van aerotopen bij veel potentieel bloeivormende soorten. Aerotopen zijn in de cyanobacteriële cellen ingesloten gasvacuoles verantwoordelijk voor het drijfvermogen van filamenten in stilstaand en turbulent water. Na bemonstering en fixatie van vijver- of kanaalwater kunnen aerotopen het bezinken van filamenten of kolonies verhinderen, zodat kwantificatie wordt bemoeilijkt en cyanobacteriële abundantie onderschat wordt. 
Verscheidene technieken kunnen toegepast worden om de gasvesikels te vernietigen en zo het drijfvermogen van Cyanobacteria te verminderen, maar hun efficiëntie is eerder beperkt. Om die reden lijkt het nuttiger de drijvende fractie in een fytoplanktonstaal te analyseren met behulp van een Sedgewick-Rafter-slide, of gebruik makend van een aangepaste opstelling van een klassieke sedimentatiekamer met gekende inhoud (Figuur 1). Daarbij wordt de telkamer gevuld met een gefixeerd of ongefixeerd substaal, afgesloten met een rond dekglas, en na enkele minuten gecontroleerd op drijvende filamenten of kolonies met een normale, niet-inverse microscoop. Celdensiteit of biovolume wordt berekend op basis van gescande oppervlakte, verdunning van de staal en het volume van de telkamer (bvb. 2.973 $\mathrm{mL})$.

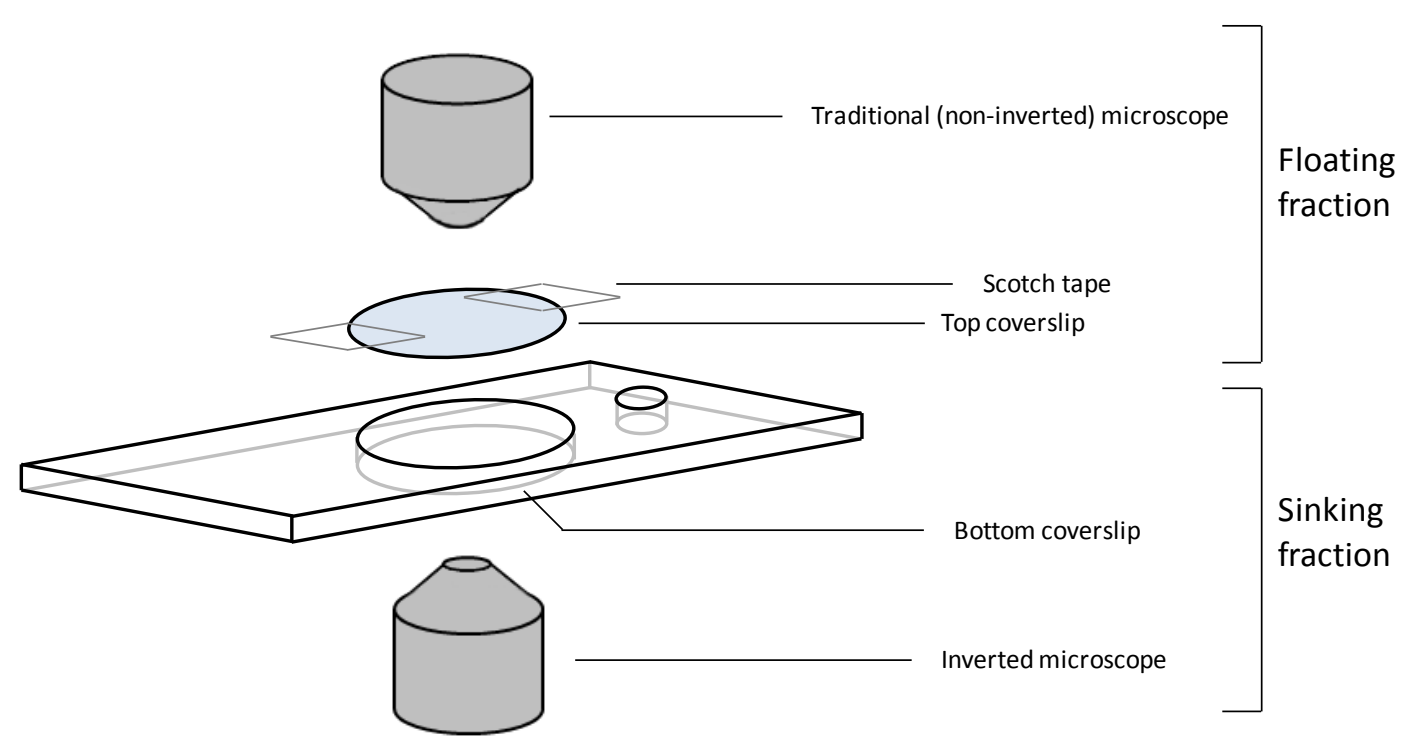

Figuur 1: Gewijzigde telkamermethode voor kwantificatie van drijvende Cyanobacteria (uit Van Onsem \& Triest 2015).

\subsubsection{Trofische status van vijvers en kanaal}

Om de trofiegraad van stilstaande of traagstromende waterlichamen te bepalen, werd een clusteranalyse uitgevoerd op basis van de indicatoren TP, fytoplanktonbiovolume, pigmentconcentratie (Chl $a+$ feofytine) en Secchidiepte per locatie en per staalnamemoment (Euclidische afstand; Statistica 8). Variabelen werden gestandaardiseerd ter correctie van de sterk verschillende schaal. Locaties werden gecategoriseerd als helder, intermediair of troebel (respectievelijke biovolumes van $<1,1-20$ en $>20 \mathrm{~mm}^{3} / \mathrm{L}$; Peretyatko et al. 2007). 


\subsubsection{Algemeen}

Een grafisch overzicht van densiteiten en biovolume van de functionele groepen van fytoplankton wordt gegeven in Figuur 2 en Figuur 3. Door het kleine celvolume van het picoplankton en de aanwezige cyanobacteriële taxa wordt het biovolume hoofdzakelijk bepaald door grotere eukaryote soorten. WPk1 bevond zich in een heldere toestand en bevatte de laagste concentratie cellen en het laagste biovolume. $\mathrm{TrBr}$ en $\mathrm{Wtml}$ bevonden zich continu of tijdelijk in een toestand met hoge fytoplankton abundanties. Het biovolume op de twee locaties in het kanaal is vergelijkbaar en ligt intermediair.

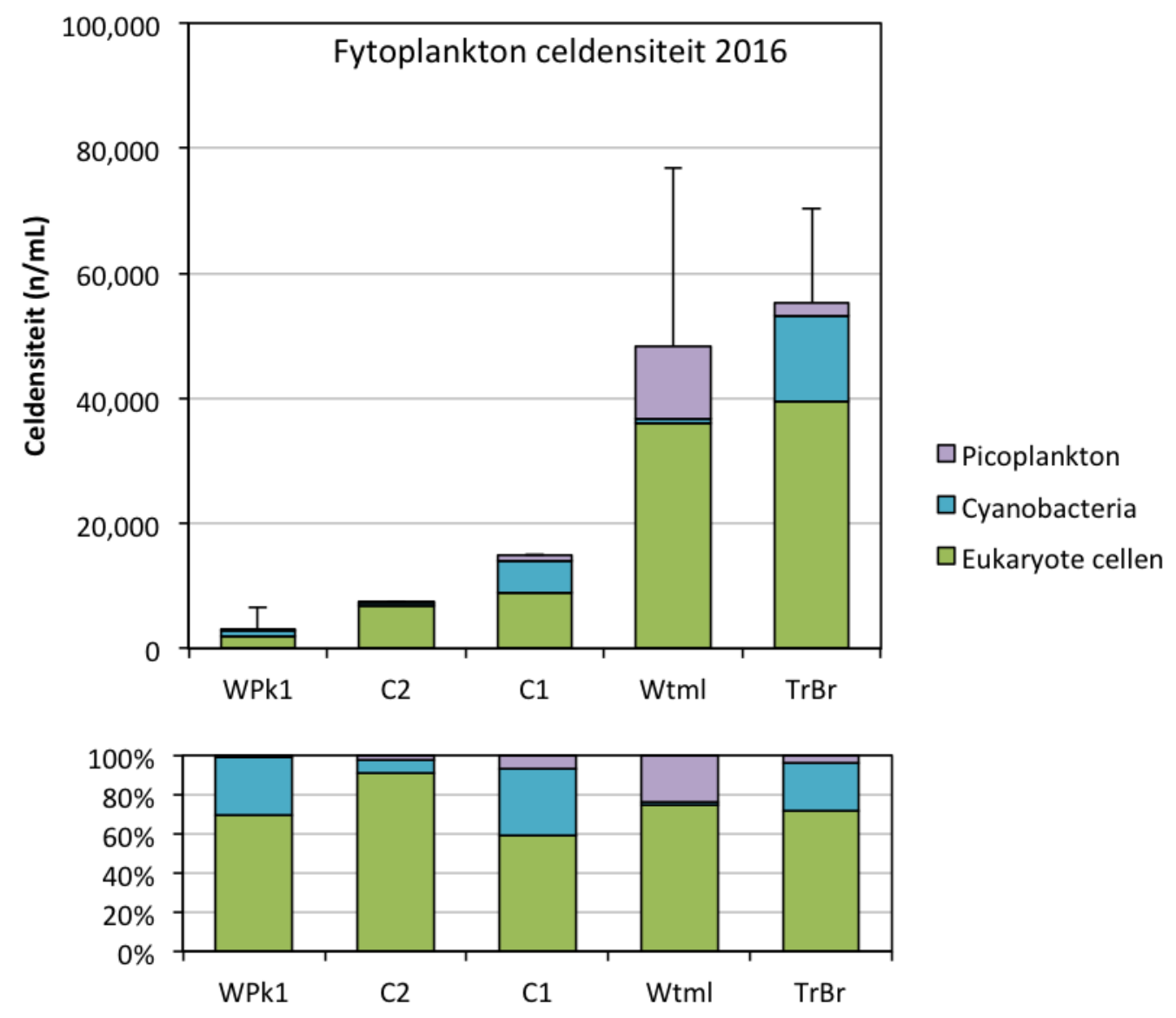

Figuur 2: gemiddelde celdensiteit (+ standaarddeviatie op totaal) van de functionele groepen fytoplankton. 

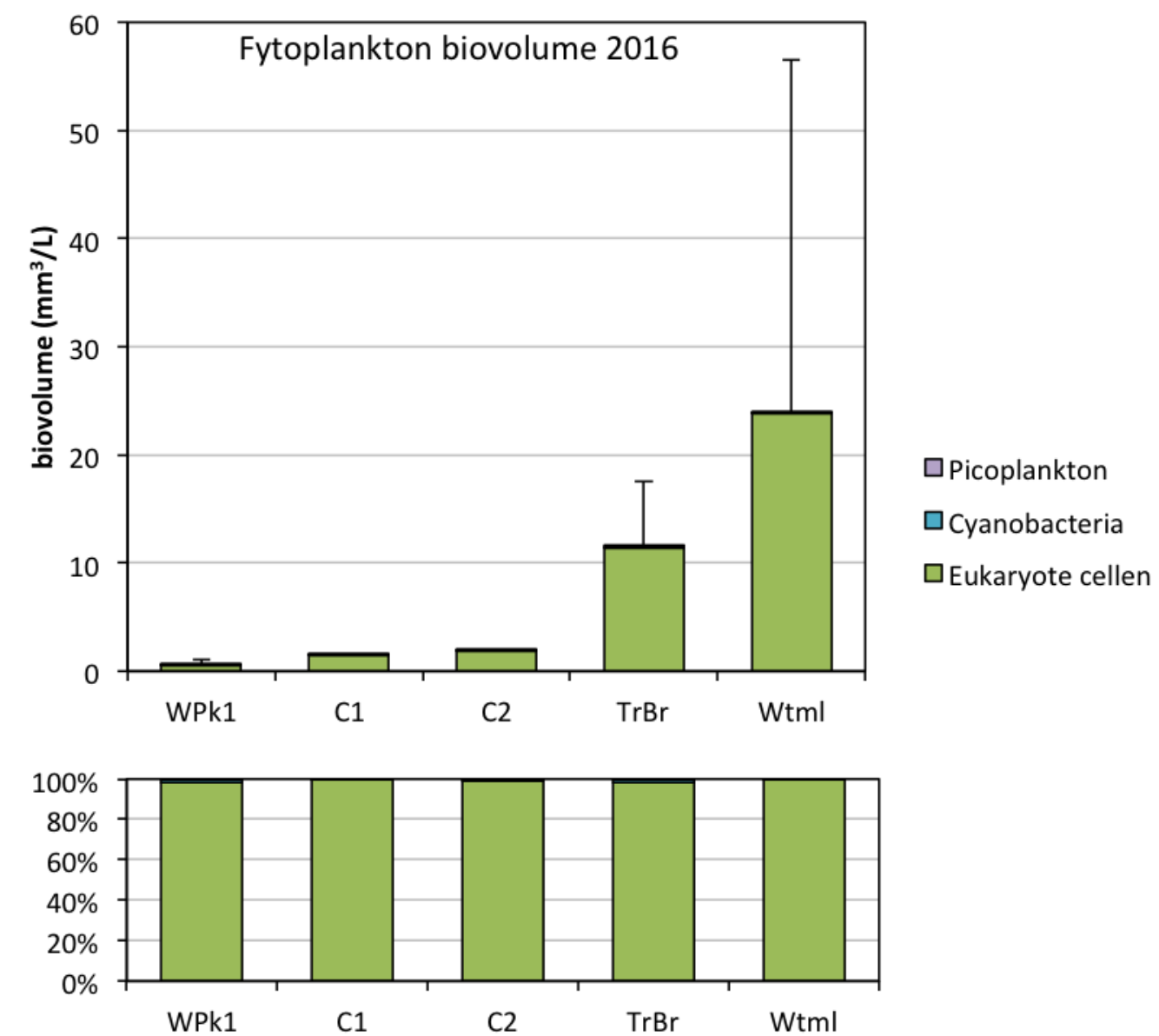

Figuur 3: gemiddeld biovolume (+ standaarddeviatie op totaal) van de functionele groepen fytoplankton.

De meest heldere locaties clusteren samen (Figuur 4). Wtml kende een omslag van een troebele toestand in juni naar een heldere situatie in augustus.

\subsubsection{EQR}

Resultaten van de monitoring van fytoplankton worden gegeven in Tabel 5. Beide staalnamelocaties in het kanaal behaalden een goede toestand ( $E Q R=0.70$ en 0.90 voor C1 en C2, respectievelijk). In de vijvers bleek de situatie variabel. De visvijver $\mathrm{TrBr}$ bevond zich in een ongunstige toestand gedurende het volledige groeiseizoen en scoort ontoereikend (EQR=0.25), terwijl Wtml na een bloei van Synura $\mathrm{sp}$. in juni vrij helder was in augustus (Figuur 4), resulterend in een matige EQR (EQR=0.55). WPk1 bleef tijdens het groeiseizoen relatief helder (goede toestand; EQR=0.90). In geen van de onderzochte sites werden alarmerende concentraties Cyanobacteria vastgesteld. 


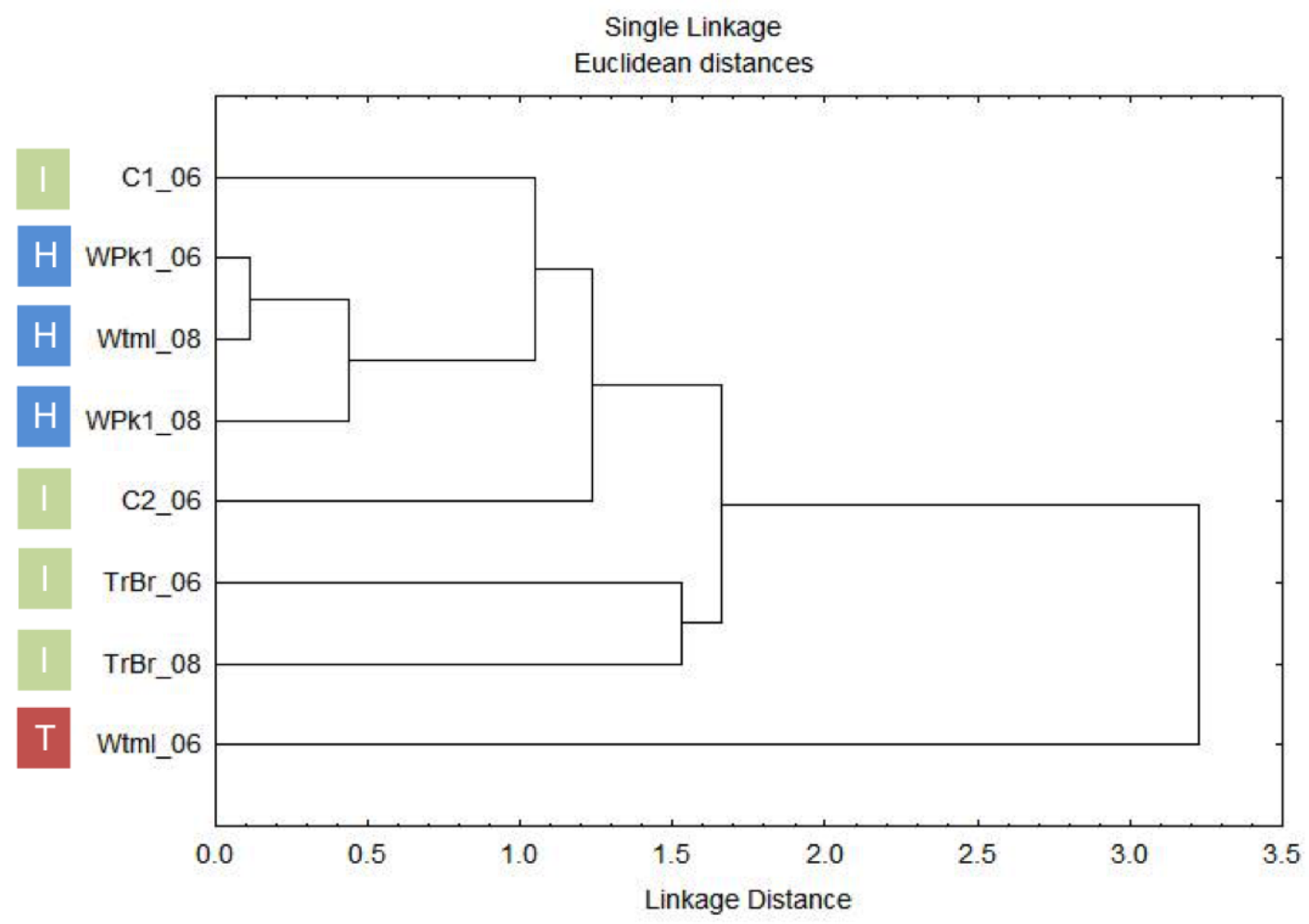

Figuur 4: Clusterdiagram op basis van TP, Secchidiepte, Chl a+feofytine en biovolume. 06: juni 2016; 08: augustus 2016. H: heldere toestand; I: intermediare toestand; T: troebele toestand.

Tabel 5: Gemeten waarden van de variabelen (scores tussen haakjes) en EQR voor fytoplankton.

\begin{tabular}{|c|c|c|c|c|c|c|c|c|}
\hline Jaar & Waterlichaam & Locatie & $\begin{array}{c}1 \\
\mathrm{TP}(\mathrm{mg} \mathrm{P} / \mathrm{L})\end{array}$ & $\begin{array}{c}2 \\
\text { Celdensiteit }(\mathrm{n} / \\
\mathrm{mL})\end{array}$ & $\begin{array}{c}3 \\
\text { Chl } a+ \\
\text { feofytine } \\
(\mu \mathrm{g} / \mathrm{L})\end{array}$ & $\begin{array}{c}4 \\
\text { Cyanobacteriële } \\
\text { celdensiteit(n/ } \\
\mathrm{mL})\end{array}$ & $\begin{array}{l}\text { Totale } \\
\text { score }\end{array}$ & EQR \\
\hline 2016 & $\mathrm{C} 1$ & Oever & $0.201(5)$ & $15029(1)$ & $10.5(5)$ & $5187(3)$ & 14 & 0.70 \\
\hline 2016 & $\mathrm{C} 2$ & Oever & $0.227(5)$ & $7521(3)$ & $8.7(5)$ & $492(5)$ & 18 & 0.90 \\
\hline 2016 & $\mathrm{TrBr}$ & Oever & $0.490(1)$ & $55208(0)$ & $132.7(1)$ & $13651(3)$ & 5 & 0.25 \\
\hline 2016 & WPk1 & Boot & $0.043(5)$ & $2941(3)$ & $6.6(5)$ & $867(5)$ & 18 & 0.90 \\
\hline 2016 & Wtml & Boot & 0.077 ( 5 ) & $48260(0)$ & $56.5(1)$ & $661(5)$ & 11 & 0.55 \\
\hline
\end{tabular}




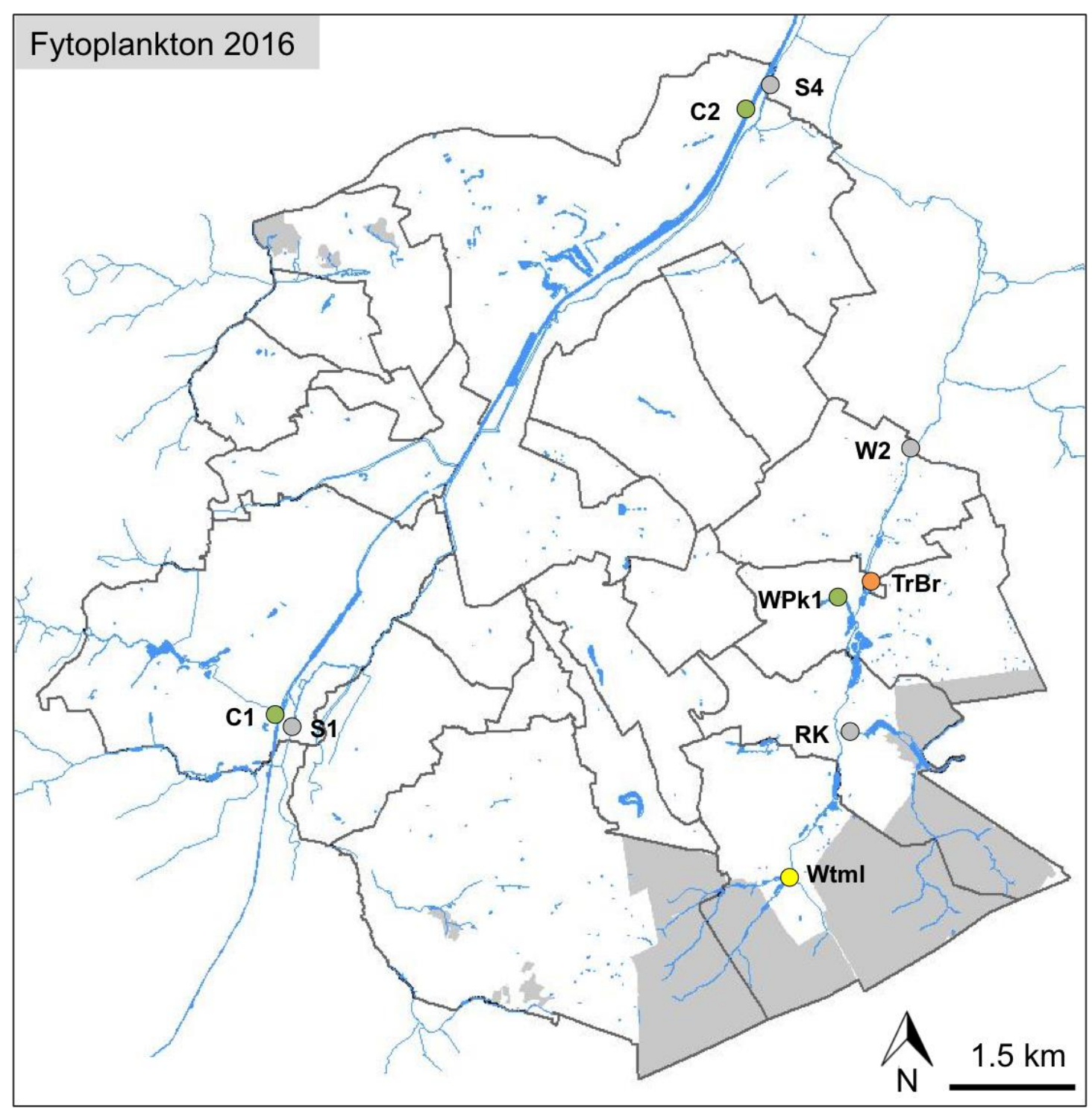

Figuur 5: Ruimtelijk overzicht van de kwaliteit voor het onderdeel fytoplankton. 


\section{Fytobenthos}

\section{Statusbeoordeling}

\subsubsection{Algemeen}

De bepaling van de ecologische waterkwaliteit steunt op de Indice de Polluosensibilité Spécifique (IPS; Prygiel et al., 1996), een op diatomeeën gebaseerde index die de algemene vervuilingsgraad van het milieu weergeeft. De IPS wordt frequent gebruikt in Europees waterkwaliteitsonderzoek omdat ze berekend wordt op basis van een uitgebreide lijst van diatomeeëntaxa waarvoor gevoeligheid en indicatorwaarde zijn gekend. De IPS-index wordt omwille van haar capaciteit tot het integreren van de effecten van verschillende typen stressoren in verschillende Europese lidstaten, Wallonië en het Brussels Hoofdstedelijk Gewest gebruikt in de beoordeling van de ecologische waterkwaliteit in functie van de Kaderrichtlijn Water (EC 2008; Triest et al. 2008).

De EQR wordt berekend door deling van de IPS-score door 20 (Van Tendeloo et al. 2004).

\subsubsection{Fytobenthos in vijvers}

Als onderdeel van de huidige monitoringscampagne werd voor de eerste keer fytobenthos bemonsterd in de opgevolgde vijvers. De KRW laat ruimte voor interpretatie wat betreft inclusie van diatomeeën in de evaluatie van meren aangezien macrofyten en fytobenthos in principe als een gecombineerd biologisch kwaliteitsonderdeel worden beschouwd (onder de noemer 'other aquatic flora' - als tegenhanger van fytoplankton). Tot hiertoe werd in het evaluatieprotocol voor vijvers in het Brussels Hoofdstedelijk Gewest geen rekening gehouden met benthische diatomeeën (Van Tendeloo et al. 2004; Triest et al. 2008; Van Onsem et al. 2014).

De indicatieve kracht van diatomeeën in meren ligt mogelijk voornamelijk in het inschatten van de trofische status (i.e. nutriëntenconcentraties; JRC 2014; Kelly et al. 2014), en de monitoring van fytobenthos zou dan waarschijnlijk de resultaten bekrachtigen van andere biotische of abiotische componenten die gerelateerd zijn aan nutriëntenconcentraties. Interkalibratie van de fytobenthosmethodologie tussen lidstaten toonde een sterke relatie aan met nutriëntenstatus, en minder met saprobiegraad (organisch materiaal; Kelly et al. 2014).

In de Brusselse vijvers heeft de combinatie van fytoplankton, macrofyten en verschillende fysisch-chemische kenmerken op zich veel potentie voor wat betreft het evalueren van nutriëntenstatus. Niettemin wordt in navolging van de procedures gevolgd door andere lidstaten in deze studie fytobenthos geanalyseerd in de vijvers. In situaties gekarakteriseerd door ingrijpende hydromorfologische wijzigingen of intense scheepvaart bieden macrofyten sowieso onvoldoende informatie omtrent de trofische situatie, en in die gevallen wordt het gebruik van diatomeeën aangeraden (JRC 2014). Het gebruik van diatomeeën als bioindicatoren kan tevens belangrijk zijn in waterlichamen die van nature abundante aquatische vegetatie ontberen, zoals het 
geval is in kleine, sterk beschaduwde bosvijvers. Het relatieve belang en de meerwaarde van fytobenthos tegenover macrofyten bij de evaluatie van vijvers in het gewest dient nader onderzocht te worden.

\subsection{Methodologie}

\subsubsection{Staalname}

In kanaal en Zenne werden artificiële substraten uitgehangen en opgehaald samen met de substraten die dienden voor opname van macro-invertebraten (Figuur 6). Elk substraat bestond uit een plastic strip (oppervlakte $15 \times 5 \mathrm{~cm}$ ) bevestigd aan een nylon touw en verzwaard met een betonnen tegel. Het substraat werd neergelaten tot op een diepte van maximum $40 \mathrm{~cm}$, afhankelijk van het doorzicht van het water. Per site werden drie replica's uitgehangen, waar mogelijk verspreid langs beide oevers. Het gebruikte plastic materiaal is commercieel beschikbaar, wetenschappelijk gevalideerd en wordt toegepast als artificieel substraat in het Duitse monitoringsprogramma (Sabine Hilt, pers. comm.). In de vijvers werd een betonnen tegel met daaraan een touw en het ondergedoken vlottende substraat op de bodem geplaatst. De kolonisatietijd bedroeg vijf à zeven weken.

In Roodkloosterbeek en Woluwe werd een traject van een vijftigtal meter afgestapt in stroomopwaartse richting, waarbij willekeurig steentjes van de bedding werden opgepikt. Waar weinig stenig materiaal te vinden was, werd de staal aangevuld met organisch substraat.

\subsubsection{Identificatie}

De biofilm op de plastic substraten werd losgeschud in een falcontube en gedigesteerd met kokende sterke zuren. De diatomeeën in de overblijvende fractie werden microscopisch tot op soortniveau geïdentificeerd. Per staal werden 500 valven geteld.

\subsubsection{Gemeenschapsanalyse}

Er werd een ordinatie uitgevoerd op de soortgegevens om gelijkenissen tussen de diatomeegemeenschappen op de staalnamelocaties te exploreren en om de affiniteit van bepaalde taxa met de verschillende types waterlichamen te visualiseren (PCA na squareroot-transformatie van tellingen; Canoco 4.5).

Het ecologische profiel van de diatomeegemeenschappen op de verschillende staalnameplaatsen werd geëxtraheerd op basis van taxonspecifieke habitatvoorkeuren bepaald door van Dam et al. (1994; OMNIDIA 5.2). 


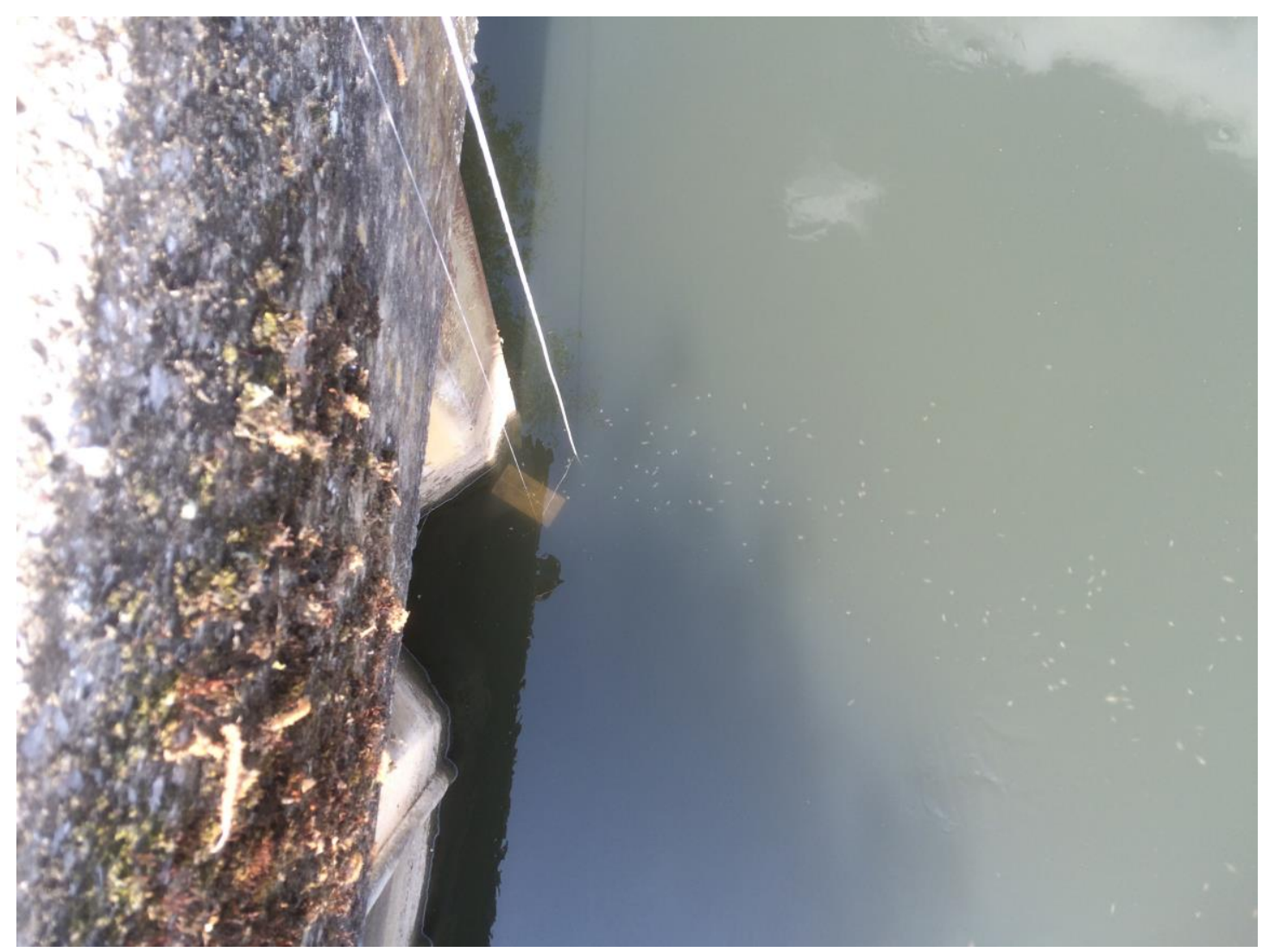

Figuur 6: Artificieel substraat uitgehangen aan S1, binnen de eufotische zone.

\subsubsection{Eutroficatie en beddingstructuur}

Om een indicatie te krijgen van de afzonderlijke rol van eutroficatie (nutriëntenvervuiling) in de afwijking t.o.v. de referentietoestand kan de Trophic Diatom Index (TDI) gebruikt worden (Kelly et al. 2001). TDI wordt uitgedrukt op een schaal gaande van 0 (zeer lage nutriëntenconcentraties) tot 100 (zeer hoge nutriëntenconcentraties).

Er moet wel rekening gehouden worden met het feit dat de interpretatie van TDI moeilijk is wanneer andere vormen van verstoring aanwezig zijn. Veel verstoringstolerante taxa kunnen bvb. zowel een hoge nutriëntenaanrijking als een andere vorm van vervuiling of fysische verstoring (zoals aanvoer van slib) aanduiden (Kelly et al. 2001). Dit geldt vooral voor beweeglijke, niet-vastgehechte soorten, die vaak voorkomen op trajecten of zones die fijn beddingmateriaal bevatten, zoals vaak het geval is stroomafwaarts bronnen van organische vervuiling. Dominantie van mobiele diatomeeën is nog geen bewijs van organische vervuiling, maar het verstoort de correcte interpretatie van TDI.

Het effect van nutriëntenaanrijking is enkel onderscheidbaar van dat van andere verstoring indien het $\%$ mobiele schaaltjes (valven) laag ligt $(<20 \%)$. Bij hogere $\%$ mobiele valven kunnen niet echt solide conclusies getrokken worden omtrent eutroficatie. Bij aanvoer van fijn sediment en slib (bvb. bij organische vervuiling of in waterlopen van hogere stroomorde) verstoort het grote aandeel beweeglijke diatomeeën het patroon dat kan afgeleid worden uit de TDI-waarden (Kelly et al. 2001). 


\subsubsection{Gemeenschapsanalyse}

Het PCA-diagram (Figuur 7) toont een clustering van kanaal-, Zenne- en vijverstalen, overeenstemmend met het typologische en kwaliteitsverschil tussen de waterlichamen. De monsterpunten in het kanaal en in de Zenne worden gekarakteriseerd door een uitgebreide, specifieke set van (vaak mobiele) soorten. Het aandeel van planktonische soorten in het kanaal blijft beperkt, hetgeen de bruikbaarheid van plastic strips in dit type waterlichaam bevestigt. Van Onsem \& Triest (2012) toonden aan dat de retentie van planktonische, mogelijk allochtone, valven door het substraat acrylwol in het kanaal hoog is en niet aanbevolen wordt.

De diatomeegemeenschappen in RK, TrBr, WPk1 en Wtml vertonen gelijkenissen, dankzij een sterke affiniteit met onder andere Achnanthidium minutissimum (AMIN) en Amphora pediculus (APED). W2 neemt een centrale positie in op het ordinatievlak en wordt gekenmerkt door een typologisch eerder indifferente soortgemeenschap.

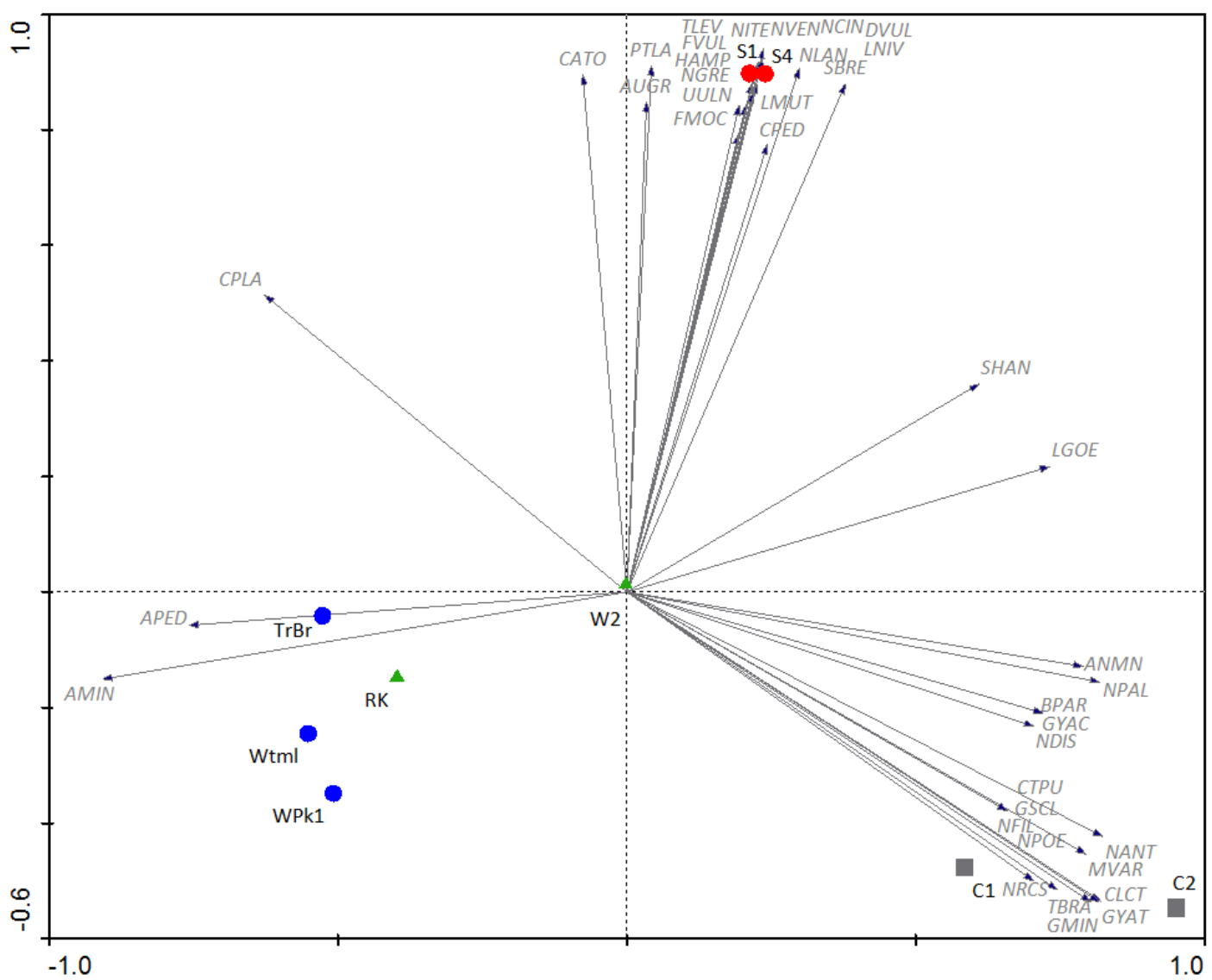

Figuur 7: PCA-diagram met diatomeesoorten (pijlen; OMNIDIA-codes) en staalnamepunten (grijze vierkanten: kanaal; rode cirkels: Zenne; groene driehoeken: Roodkloosterbeek en Woluwe; blauwe cirkels: vijvers). Enkel soorten waarvan meer dan 50\% variatie verklaard wordt door de eerste twee assen zijn weergegeven.

Figuur 8 geeft de ecologische profielen weer van de staalnamelocaties. De meeste sites lijken zwak alkalisch, met uitzondering van WPk1 en Wtml, die een meer 
neutraal karakter hebben. De noordelijk gelegen monsterpunten in Zenne en kanaal neigen qua saliniteit naar een licht brakke toestand. De Zenne huisvest weinig taxa die gevoelig zijn voor lage zuurstofconcentraties en wordt gekenmerkt door een relatief hoge saprobiegraad (een maat voor de organische belasting).

Verrassend genoeg lijken Woluwe en twee vijvers (Wtml en WPk1) eveneens te kampen met sporadisch zuurstoftekort, hoewel de methode mogelijk te indirect is om op dit vlak uitsluitsel te bieden. Een extra aanwijzing voor potentieel zuurstoftekort in WPk1 is de indicatie van hoge organische belasting in deze vijver. Alle locaties zijn sterk aangerijkt met nutriënten (trofische graad). Tenslotte kunnen veel gevonden diatomeesoorten in natte omstandigheden uit water overleven, zoals blijkt uit het aerofiele karakter van veel soorten.

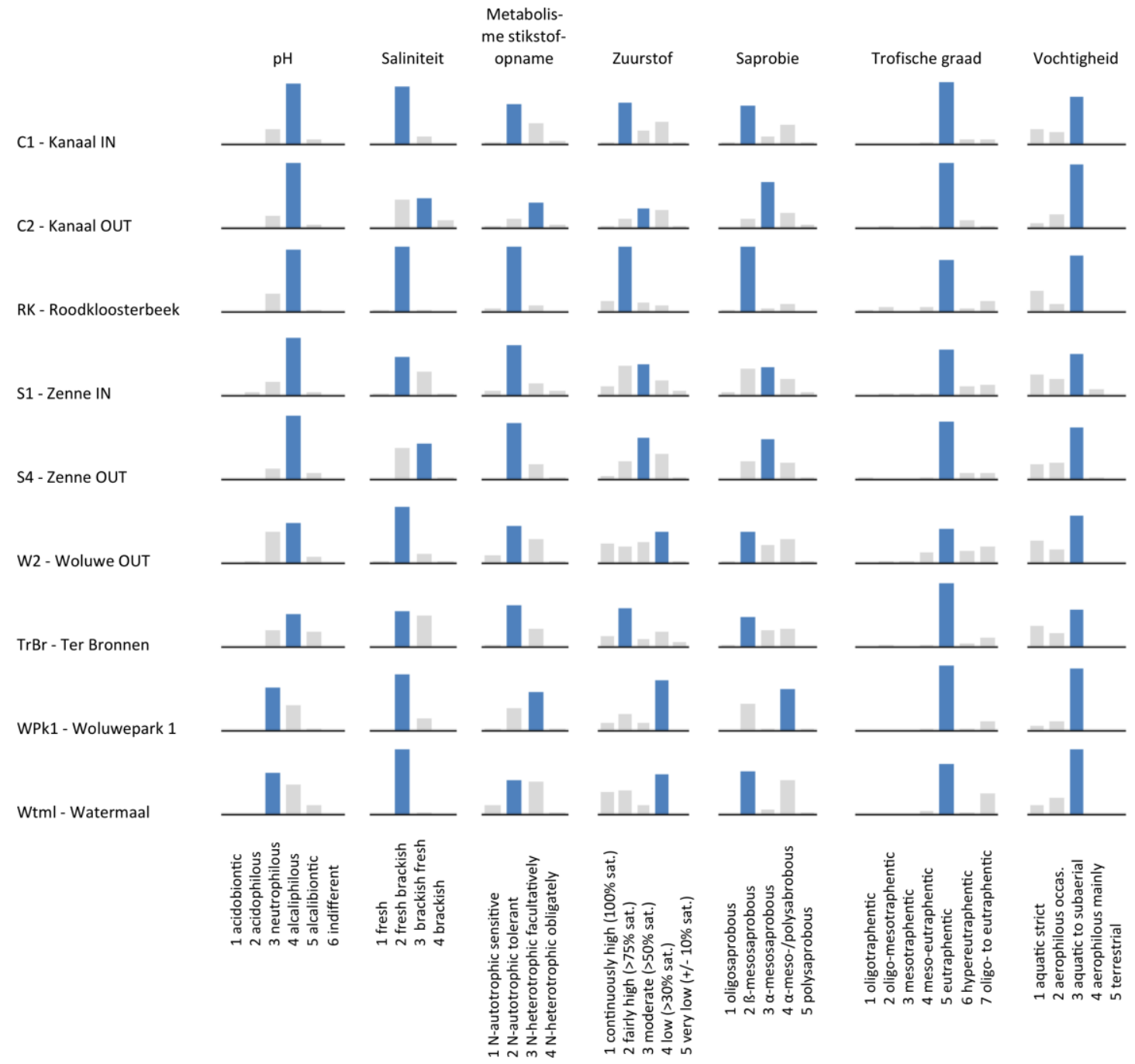

Figuur 8: Ecologische profielen van de locaties gebaseerd op diatomeepreferenties volgens van Dam et al. (1994). Zwaartepunt van de distributies in blauw.

\subsubsection{Eutroficatie en beddingstructuur}

In Figuur 9 worden resultaten voor TDI grafisch weergegeven in relatie tot het aandeel mobiele valven. Enkel voor RK (potentieel slechte kwaliteit op vlak van 
nutriënten) en Wtml (matige kwaliteit) geeft TDI een indicatie van de graad van eutroficatie. Nochtans werd in RK een relatief lage TP-concentratie gemeten (0.046 $\mathrm{mg} \mathrm{P} / \mathrm{L})$, al gaat het om een puntmeting.

In de deelstroomgebieden vindt veelal een verschuiving plaats naar een groter aandeel mobiele diatomeeën gaande van bovenstroomse locaties naar stroomafwaarts gelegen punten. In Zenne en kanaal lijkt de aanvoer van fijn materiaal plaats te vinden op een beduidend intensere schaal dan wat van nature kan verwacht worden. In combinatie met vaststellingen op het terrein kan gesteld worden dat de vuilvracht van sediment in deze waterlichamen - zeker aan de noordgrens van het gewest - significant is. De gevolgen zijn niet enkel voor rekening van de autotrofe organismen op de bodem, maar ook voor de sterk van het type beddingmateriaal afhankelijke macrofauna.

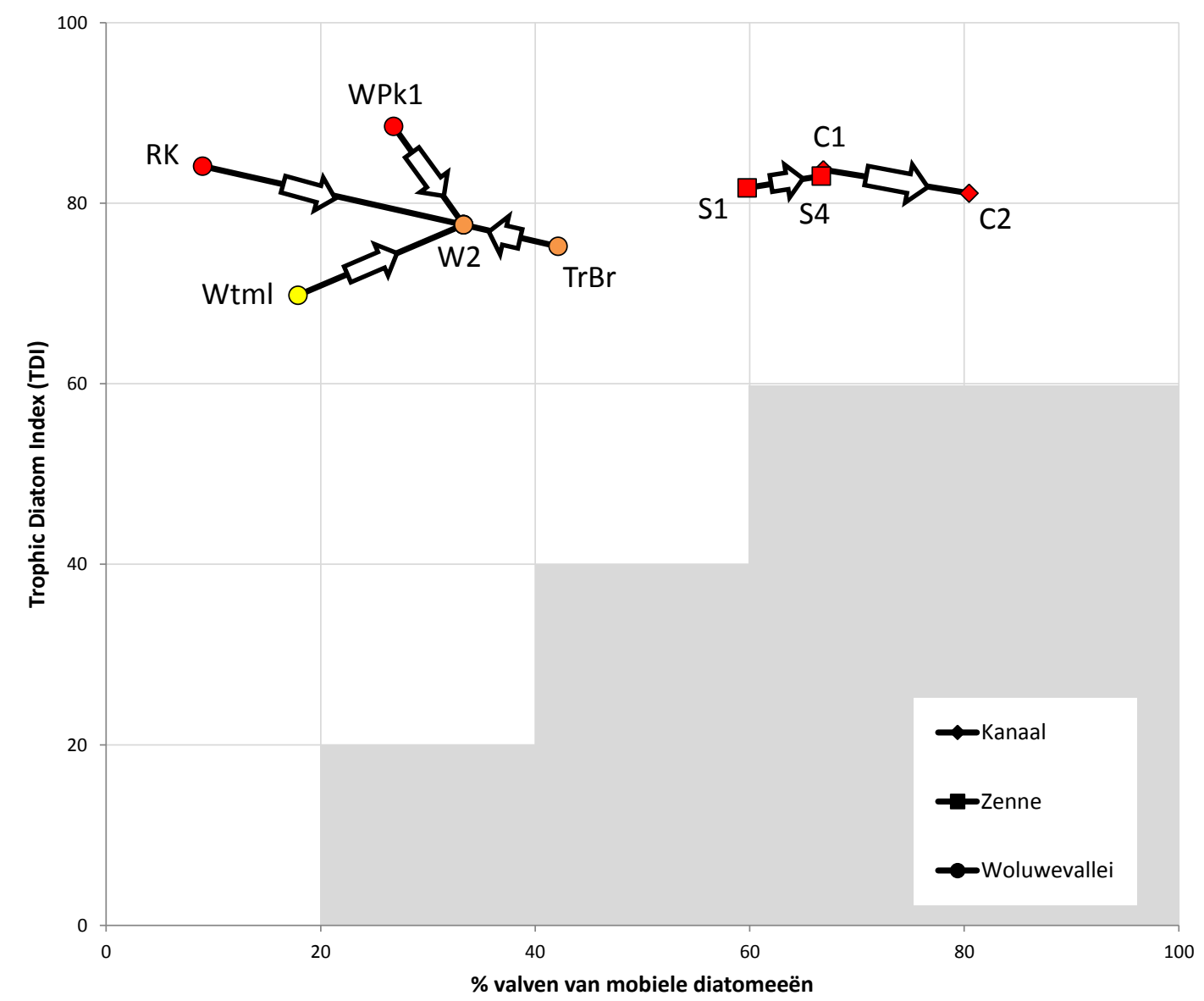

Figuur 9: Verband tussen het aandeel beweeglijke benthische diatomeeën en TDI-waarden (met kleurcode o.b.v. TDI-klasse (cf. Tabel 6)) per waterlichaam (Zenne en kanaal) of stroomgebied (Woluwebekken). Locaties rechtsboven worden gekenmerkt door een hoge slibdepositie en onduidelijke nutriëntenstatus, terwijl voor locaties aan de linkerzijde van de grafiek TDI een indicatie geeft van de nutriëntenstatus. Grijze zone: onwaarschijnlijk. Pijlen geven de hydrologische relatie (stroomrichting) weer.

\subsubsection{EQR}

De op basis van IPS berekende EQR geeft voor alle staalnamelocaties exclusief RK een matige kwaliteit aan (Tabel 6; Figuur 10). Enkel RK haalt het goed ecologisch 
potentieel met een EQR van 0.78. Vergeleken met vorige monitoringscampagne (2013) blijft de kwaliteit voor fytobenthos in het kanaal stabiel. Voor de Zenne betekent de matige kwaliteit een verbetering ten opzichte van vorige jaren. De Woluwe kent een markante achteruitgang, mogelijk als gevolg van geïntensifieerde slibdepositie en/of overstort door hevige regenval (zie 8.3.2). Wat de vijvers betreft, bestaat geen temporele dataset.

Tabel 6: Diatomee-indices en EQR (IPS/20) voor 2016. IPS: Indice de Polluosensibilité Spécifique; IBD: Indice Biologique Diatomées; TDI: Trophic Diatom Index; \%PT: \% pollution tolerant valves.

\begin{tabular}{lccccc}
\hline Locatie & IPS & IBD & TDI & \%PT & EQR 2016 \\
\hline C1 & 12.70 & 12.40 & 83.70 & 16.8 & 0.64 \\
C2 & 9.70 & 9.60 & 81.10 & 22.8 & 0.49 \\
RK & 15.50 & 14.90 & 84.10 & 2.7 & 0.78 \\
S1 & 10.80 & 10.60 & 81.70 & 28.8 & 0.54 \\
S4 & 10.60 & 11.30 & 83.00 & 39.8 & 0.53 \\
W2 & 11.60 & 12.30 & 77.60 & 30.9 & 0.58 \\
TrBr & 10.90 & 11.50 & 75.20 & 30.3 & 0.55 \\
WPk1 & 9.80 & 10.20 & 88.50 & 59 & 0.49 \\
Wtml & 12.60 & 12.80 & 69.80 & 29.1 & 0.63 \\
& & & & & \\
\hline
\end{tabular}




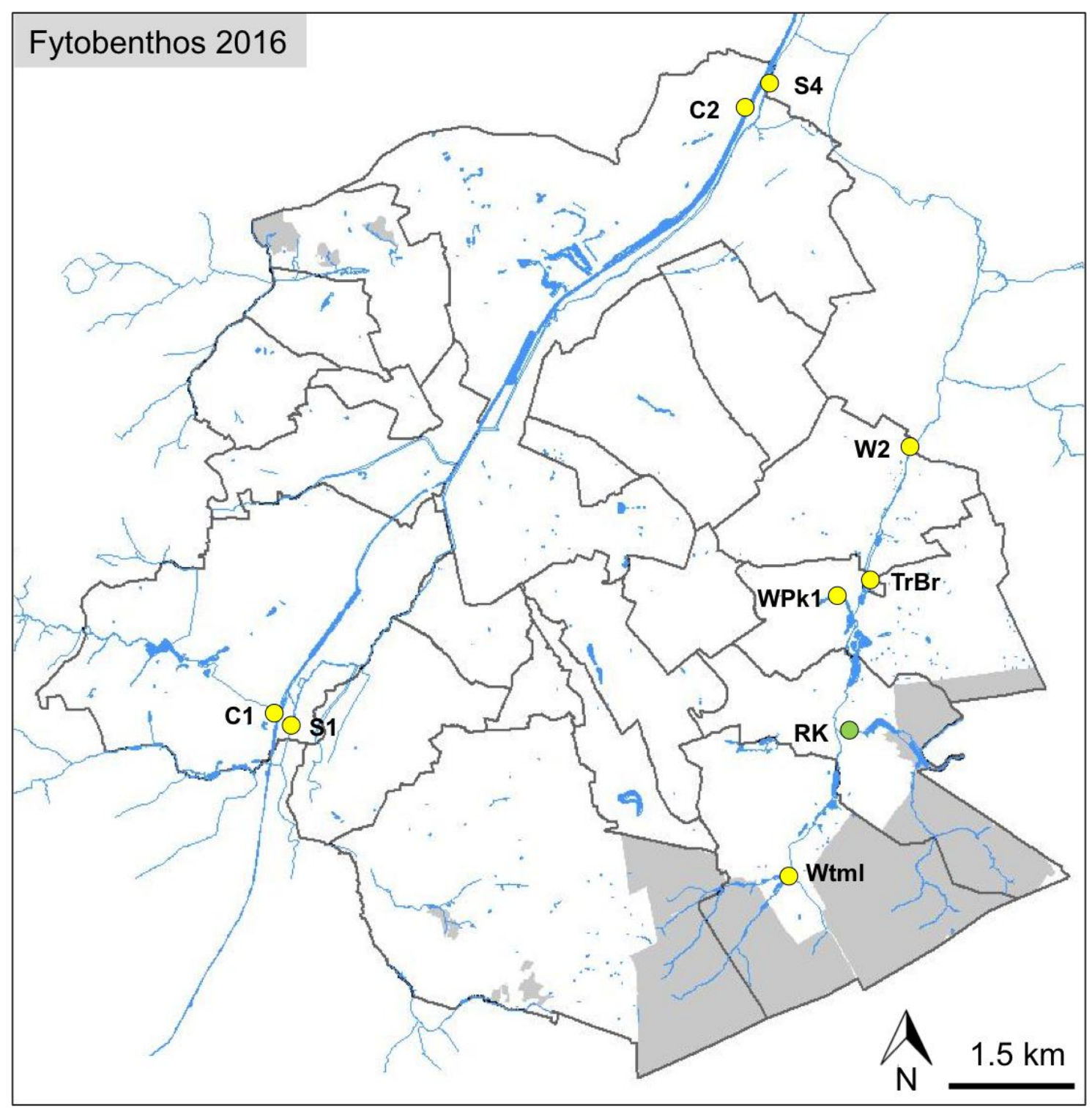

Figuur 10: Ruimtelijk overzicht van de kwaliteit voor het onderdeel fytobenthos. 


\section{Macrofyten}

\section{Statusbeoordeling}

\subsubsection{Algemeen}

Tabel 7 geeft een overzicht van de metrieken die gebruikt worden bij de berekening van de EQR voor macrofyten. Voor kleinere waterlopen, Zenne en vijvers worden aparte beoordelingsmethodes toegepast.

\subsubsection{Wijzigingen in beoordeling vijvers}

Bij de analyse van de EQR voor macrofyten werd de oorspronkelijke methodologie voor vijvers aangepast door toevoeging van drie parameters die de nadruk vergroten van samenstelling, fitness en soortenrijkdom in de gemeenschap van submerse macrofyten (Tabel 7; Van Onsem \& Triest 2015). De originele zes variabelen gebruikt in het protocol houden voldoende rekening met vegetatiestructuur en aanwezigheid of abundantie van verschillende groeivormen, maar zijn niet gedetailleerd genoeg om harmonisatie toe te laten met elders gevolgde procedures (bvb. Vlaanderen), noch met monitoring in het kader van de habitatrichtlijn.

Soortenarme gemeenschappen of de aanwezigheid van tolerante macrofyten werden oorspronkelijk niet negatief geëvalueerd. Omwille van het belang en de indicatieve waarde van submerse macrofyten in ondiepe meren en vijvers, wordt de opname van een aantal extra elementen relevant geacht.

De rationale achter de insluiting van extra variabelen wordt hieronder toegelicht. De EQR voor macrofyten wordt berekend door het opsommen van de deelscores en de totale waarde te delen door de referentiescore van 90.

\section{Seizoenale evolutie}

Sommige vijvers in het Brussels Hoofdstedelijk Gewest vertonen een trend naar verhoogde totale of relatieve abundantie van een of meerdere eutroficatie- en beschaduwingstolerante submerse macrofyten (Potamogeton pectinatus en Ceratophyllum demersum) in de loop van het groeiseizoen (Figuur 11; Van Onsem \& Triest 2015). Beide soorten zijn in staat om te gaan met verhoogde turbiditeit aangezien ze biomassa kunnen concentreren dichtbij het wateroppervlak. De hoge fenotypische plasticiteit van $P$. pectinatus laat een snelle verticale groei toe gevolgd door uitwaaieren van een horizontaal bladerdek, onder specifieke omgevingscondities. C. demersum is daarentegen capabel om stijgende turbiditeit het hoofd te bieden omdat ze niet afhankelijk is van een wortelstelsel en dus minder beïnvloed wordt door veroudering en afsterven van lagere delen. Andere soorten, zoals kranswieren (Characeae), Potamogeton pusillus of Elodea nuttallii, lijken minder tolerant (hoewel kranswieren soms marginaal aanwezig blijven). 
Tabel 7: Deelmetrieken en beoordeling voor macrofyten. *: waterlopen excl. Zenne. **: score voor Zenne staat tussen haakjes.

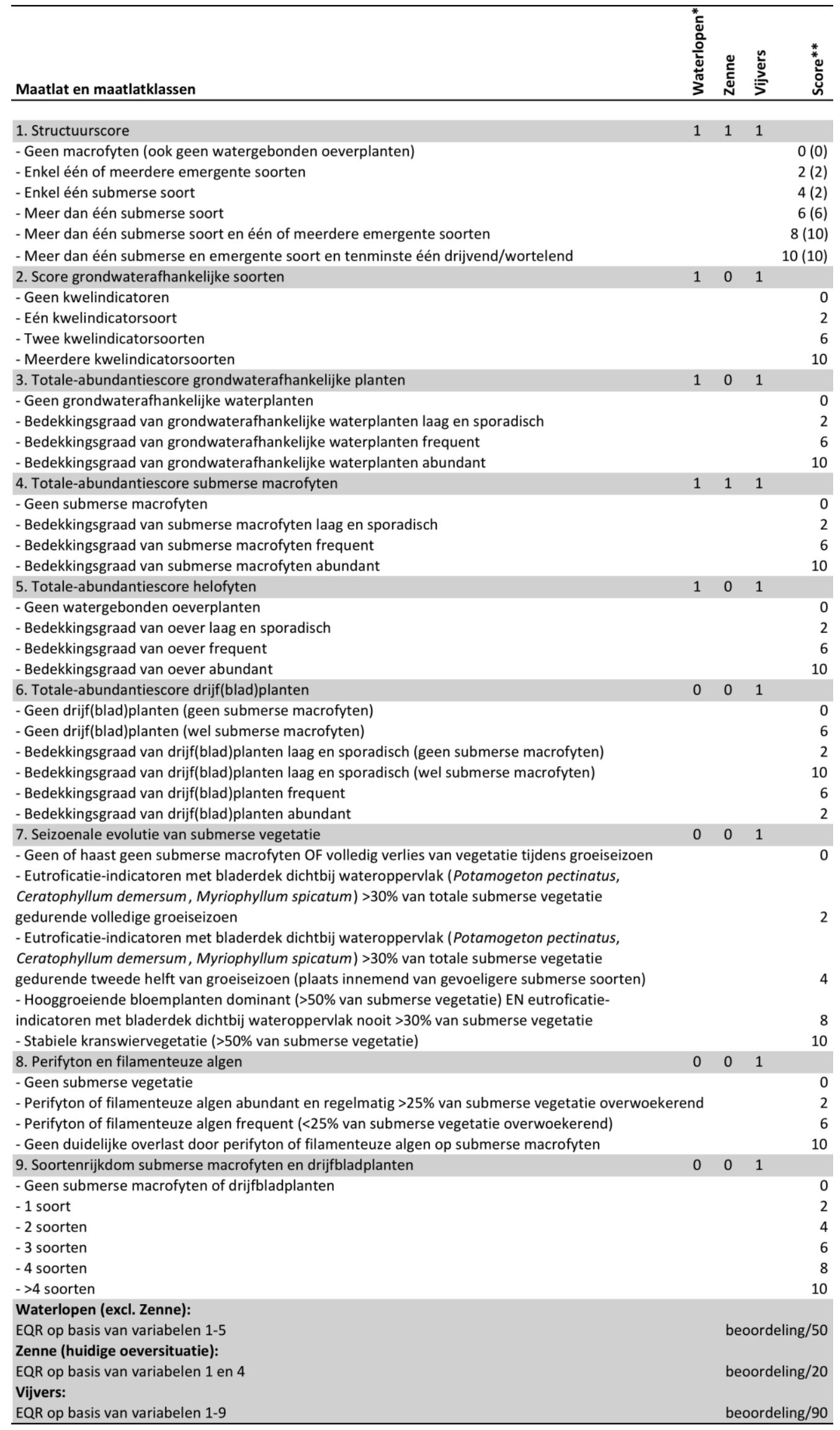




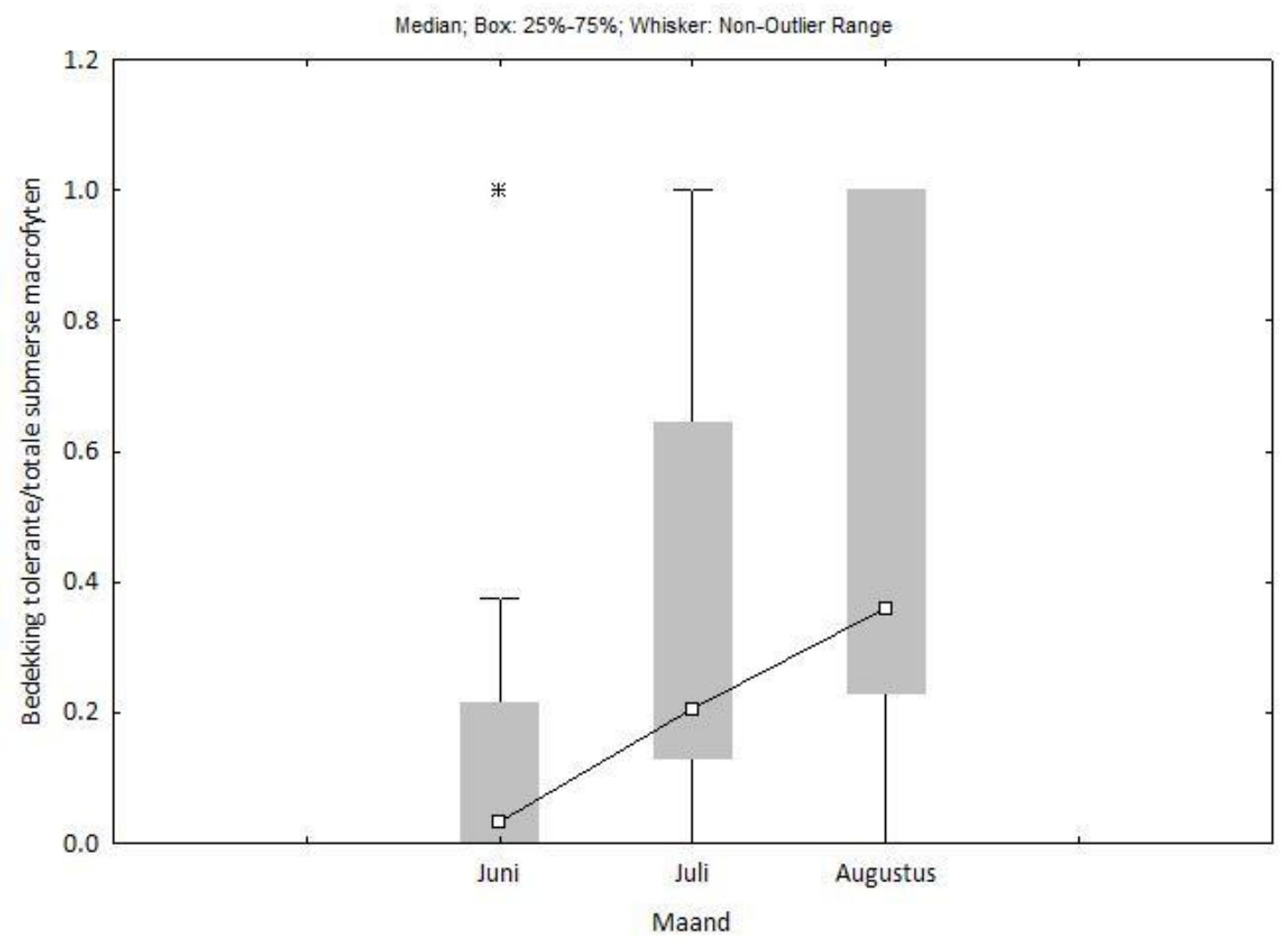

Figuur 11: Temporele evolutie van de ratio tussen bedekking van tolerante en volledige gemeenschap van submerse macrofyten doorheen het groeiseizoen in vijvers in 2013-2014 ( $n=9)$; Friedman ANOVA ( $p<0.01)$. Overgenomen uit Van Onsem \& Triest (2015).

In de Brusselse vijvers vormen de vaak monospecifieke standplaatsen van hoogtolerante soorten frequent een vergevorderd stadium in de omschakeling van een helderwatertoestand naar een troebele, vegetatieloze conditie. De evolutie naar dominantie van tolerante macrofyten kan gebeuren binnen een seizoen of gedurende meerdere jaren, en zou in gebiomanipuleerde vijvers een symptoom kunnen zijn van graduele achteruitgang.

Het valt niet geheel uit te sluiten dat de regelmatig waargenomen stijging van deze soorten slechts een effect is van seizoenale successie, maar de autecologische karakteristieken van $P$. pectinatus en $C$. demersum alsook de ogenschijnlijke achteruitgang van omgevingscondities (stijgende fytoplanktonabundantie) vóór de intrede van ongunstige weersomstandigheden in de late zomer tonen aan dat de verhoogde prominentie van tolerante soorten binnen de gemeenschap van submerse vegetatie vermoedelijk het gevolg is van een toename van de turbiditeit. Van Onsem \& Triest (2015) vonden een significante correlatie van de verhouding tussen tolerante versus totale macrofytengemeenschap met enerzijds $\mathrm{Chl} a$ en de Secchidiepte anderzijds.

De variabele die dient voor de evaluatie van (seizoenale) trends in de submersemacrofytengemeenschap houdt rekening met verschillende situaties (Tabel 7). Dominantie van stabiele, uitgestrekte kranswiermatten wordt hoog gewaardeerd (in navolging van evaluatie van het habitattype H3140 voor de Habitatrichtlijn), terwijl een verder onderscheid wordt gemaakt tussen gevoelige of weinig tolerante submerse macrofyten en tolerante, bladerdekvormende soorten ( $P$. pectinatus en $C$. 
demersum, mogelijk ook Myriophyllum spicatum; T'Jollyn et al. 2009). Een grenswaarde van 30\% wordt gehanteerd boven dewelke de verhouding negatief wordt geïnterpreteerd (analoog aan T'Jollyn et al. 2009).

\section{Filamenteuze algen en perifyton}

Eutrofiëring en vispredatie op slakken kunnen de groei van perifyton (autotrofe organismen die ondergedoken macrofyten als substraat gebruiken) en filamenteuze algen (draadwieren) stimuleren (Jones \& Sayer 2003). Om nutriëntenaanrijking en het schadelijke effect van hoge abundantie van perifyton of overwoekerende filamenteuze algen te beoordelen, werd een extra variabele toegevoegd ter beoordeling van de resulterende overlast (Tabel 7).

De inschatting van deze variabele focust op duidelijk zichtbare aanwezigheid van grote hoeveelheden perifyton (zowel microscopische algen of Cyanobacteria als macroscopische soorten zoals waternetje Hydrodictyon reticulatum, of - wanneer macrofyten duidelijk worden overwoekerd - darmwier Enteromorpha intestinalis) en filamenteuze algen die submerse macrofyten als substraat gebruiken. In principe worden losgeslagen of drijvende, vrijgroeiende matten van filamenteuze algen (cf. Hillebrand 1983) apart geëvalueerd met de parameter voor abundantie van drijf(blad)planten, hoewel het onderscheid soms vaag kan zijn.

Hoge concentraties perifyton kunnen visueel gecontroleerd worden door eenvoudig schudden van biomassa onder water of in een met water gevulde plastic zak, of door het afschrapen van het oppervlak van macrofyten om de dikte van de biofilm te beoordelen. Microscopische analyse of bepaling van pigmentconcentraties van perifyton zijn niet nodig.

\section{Soortenrijkdom van submerse macrofyten en drijfbladplanten}

De oorspronkelijke methodologie voor berekening van EQR voor macrofyten in vijvers houdt beperkt rekening met soortenrijkdom, met focus op de algemene vegetatiestructuur van de vijver, oever en eventuele aangrenzende moerassige zones. Zowel ECOFRAME (Moss et al. 2003; aangepast voor de Brusselse situatie door De backer 2011) als de Vlaamse methodologie voor beoordeling van het habitatrichtlijntype H3150 (T'Jollyn 2009) benadrukken het belang van soortenrijkdom in waardevolle aquatische vegetaties. Om die reden werd het protocol voor vijvers uitgebreid met de insluiting van een afzonderlijke variabele gebaseerd op soortenrijkdom van submerse macrofyten en gewortelde drijfbladplanten (Tabel 7).

De evaluatie van deze deelmaatlat volgt in grote lijnen de door De Backer (2011) aangepaste ECOFRAME-grenswaarden, om rekening te houden met het sterk gewijzigde karakter en de relatief kleine oppervlakte van vijvers.

\subsubsection{Habitattypes en de Habitatrichtlijn}

Op basis van de macrofytenmonitoring kan voor de vijvers het potentieel nagegaan worden voor kwetsbare habitattypes die opgenomen zijn in de Habitatrichtlijn en van gemeenschapsbelang zijn voor de Europese Unie. In het Brussels Hoofdstedelijk Gewest werden in het kader van Natura 2000 drie Speciale Beschermingszones aangeduid met een netwerk aan beboste zones en parken, en inclusief verschillende 
vijvers en waterlopen (Van Calster et al. 2010). Om de doelstellingen in functie van de Habitatrichtlijn te specifiëren, analyseerden Van Onsem \& Triest (2015) de aanwezigheid en het potentieel van de aquatische habitattypes H3140 ('kalkhoudende oligo-mesotrofe waterlichamen met benthische kranswiervegetaties') en H3150 ('van nature eutrofe meren met vegetaties van het type Magnopotamion of Hydrocharition'; Figuur 12) in Brusselse vijvers, aan de hand van definities verstrekt door de Europese Commissie (EC 2007) en de in Vlaanderen en Frankrijk toegepaste methodologie voor beoordeling van de habitatstatus (MNHN 2002; T'Jollyn et al. 2009).

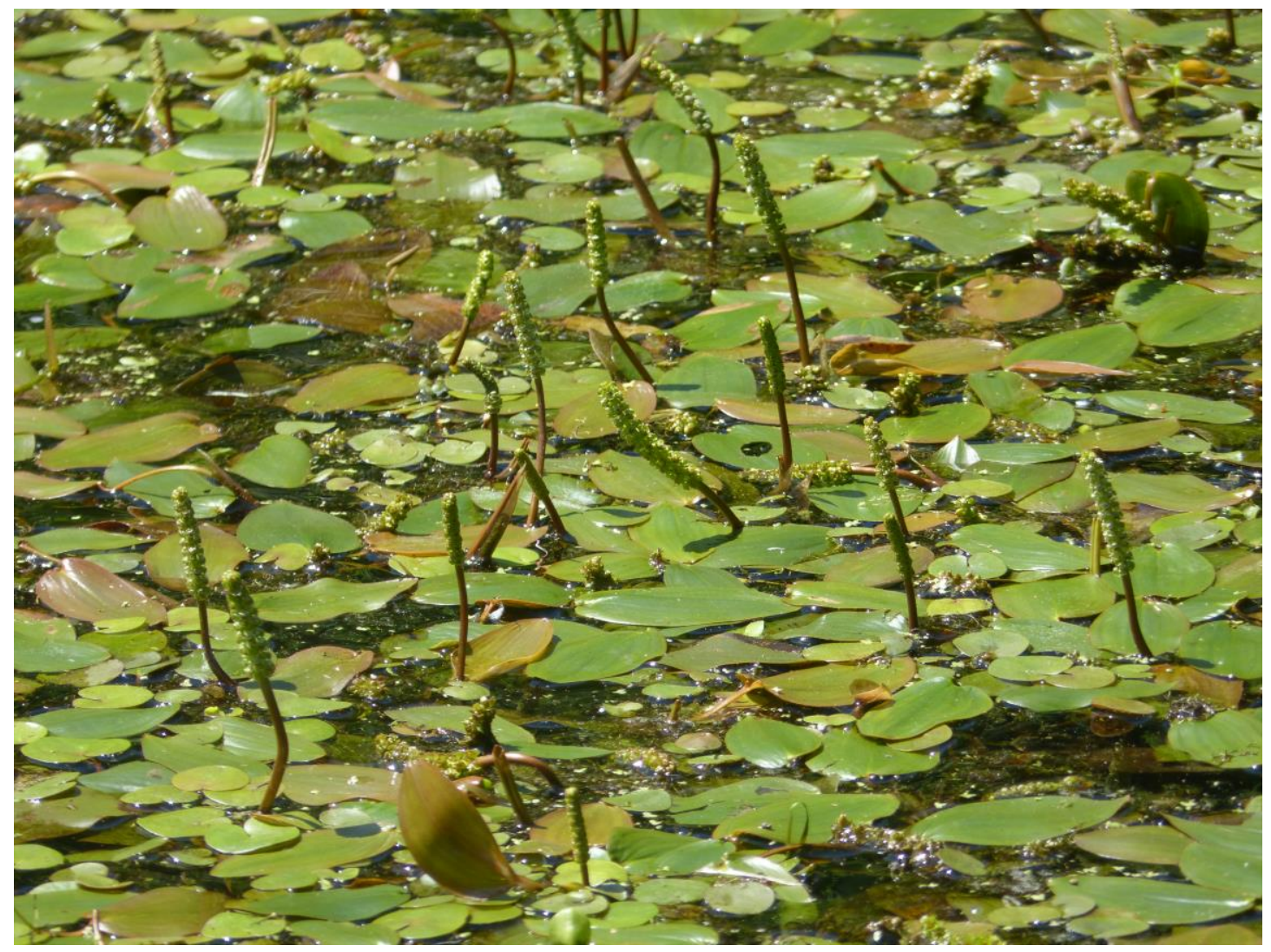

Figuur 12: Een kandidaat voor habitattype H3150 met sleutelsoort Kikkerbeet (Hydrocharis morsusranae) en relictsoort Drijvend fonteinkruid (Potamogeton natans) in natuurgebied Tommelen, Hasselt.

Ondanks grote uitdagingen eigen aan de stedelijke of verstedelijkte context, en ondanks de voorlopige afwezigheid van typespecifieke sleutelsoorten, werden de onderzochte habitattypes in de periode 2013-2014 aangetroffen in drie verschillende vijvers (Van Onsem \& Triest 2015). Het habitattype H3140 is delicaat en bestaat in Brussel typisch uit een pioniervegetatie van tolerante kranswieren, met een verwachte levensduur van onder gunstige omstandigheden hooguit enkele jaren. Een relictvegetatie van $\mathrm{H} 3150$ werd aangetroffen in WPk1, en lijkt stabieler. Voor het herstel van beide habitatten zou op termijn kunnen gestreefd worden naar vermindering van nutriëntenbeschikbaarheid, eventuele herintroductie van sleutelsoorten en een flexibel beheer dat inspeelt op bescherming en stimulatie van gunstige situaties wanneer die zich op het terrein voordoen. Het uitgraven en in stand houden van kleine, visvrije poelen is een bijkomende, kostenefficiënte, optie, 
die ook amfibieën kan helpen aantrekken. De beheersmaatregelen zouden moeten toelaten om op metapopulatieniveau vestiging, behoud en dispersie van kenmerkende soorten te garanderen (Van Onsem \& Triest 2015).

\subsection{Methodologie}

\subsubsection{Vegetatieopname}

Vegetatieopname van hydrofyten en emergente planten gebeurde vanaf de oever (Zenne en $\mathrm{TrBr}$ ), met behulp van een waadpak (Roodkloosterbeek en Woluwe) of met een boot. In de waterlopen werd een transect van $100 \mathrm{~m}$ afgestapt. Voor de Woluwe werd de vegetatie geanalyseerd in tien segmenten van tien meter. In de vijvers werden soortbedekkingen geschat in vijf plots (gedetailleerde opname) en werd de totale bedekking van de aanwezige groeivormen op vijverschaal genoteerd. Bij de analyse van watergebonden oevervegetatie werd onder meer de aanwezigheid en abundantie van potentiële kwelindicatoren onderzocht (Tabel 8).

Tabel 8: Niet-exhaustieve lijst van kwelindicatoren of freatofyten die in het Brussels gewest kunnen aangetroffen worden. Groeivorm: $\mathrm{H}$ - helofyt; A - amfibische plant; O - oeverplant.

\begin{tabular}{llc}
\hline Wetenschappelijke naam & Nederlandse naam & Groeivorm \\
\hline & Dotterbloem & \\
Caltha palustris & Moeraszegge & $\mathrm{H}$ \\
Carex acutiformis & Oeverzegge & $\mathrm{H}$ \\
Carex riparia & Lidrus & $\mathrm{H}$ \\
Equisetum cf. palustre & Gele lis & $\mathrm{H}$ \\
Iris pseudacorus & Wolfspoot & $\mathrm{H}$ \\
Lycopus europaeus & Watermunt & $\mathrm{H}$ \\
Mentha aquatica & Witte waterkers & $\mathrm{H}$ \\
Nasturtium cf. officinale & Waterpeper & $\mathrm{O}$ \\
Polygonum hydropiper & Geoord helmkruid & $\mathrm{O}$ \\
Scrophularia auriculata & Blauw glidkruid & $\mathrm{O}$ \\
Scutellaria galericulata & Bitterzoet & $\mathrm{O}$ \\
Solanum dulcamara & Grote egelskop & $\mathrm{H}$ \\
Sparganium erectum & Blauwe waterereprijs & $\mathrm{H}$ \\
Veronica anagallis-aquatica & Beekpunge & $\mathrm{H}$ \\
Veronica beccabunga & &
\end{tabular}

\section{Resultaten}

\subsubsection{EQR}

Een overzicht van de deelscores en EQR voor macrofyten wordt gegeven in Tabel 9. In de Roodkloosterbeek werd zoals gewoonlijk geen submerse vegetatie aangetroffen, hoewel de EQR (0.16) licht verbeterde ten opzichte van vorige campagne door de aanwezigheid van oever- of moeraszegge. Bij binnenkomst van het gewest (S1) werden in de Zenne geen macrofyten waargenomen, mogelijk als 
gevolg van baggerwerkzaamheden. De slechte kwaliteit op vlak van macrofyten op deze plaats $(E Q R=0)$ betekent dus niet noodzakelijk een achteruitgang van de ecologische toestand. Verderop (S4) groeide nog steeds schedefonteinkruid (Potamogeton pectinatus), waardoor de Zenne bij het verlaten van het gewest matig scoort $(E Q R=0.40)$.

Tabel 9: Deelscores en EQR voor macrofyten in 2016. Grijs: niet relevant. SM: submerse macrofyten; EM: emergente macrofyten; FLM: drijfbladplanten; FFM: vrijdrijvende macrofyten; FA: filamenteuze algen.

\begin{tabular}{|c|c|c|c|c|c|c|c|c|c|c|c|}
\hline Site & $\begin{array}{c}c 1 \\
\text { Vegetatie- } \\
\text { structuur }\end{array}$ & \begin{tabular}{l}
\multicolumn{1}{c}{2} \\
Soortenrijk- \\
dom \\
freatofyten
\end{tabular} & $\begin{array}{c}3 \\
\text { Abundantie } \\
\text { freatofyten }\end{array}$ & \begin{tabular}{l}
\multicolumn{1}{c}{4} \\
Abundantie \\
SM
\end{tabular} & \begin{tabular}{l}
\multicolumn{1}{c}{5} \\
Abundantie \\
EM
\end{tabular} & \begin{tabular}{l}
\multicolumn{1}{c}{6} \\
Abundantie \\
FLM+FFM
\end{tabular} & \begin{tabular}{l}
\multicolumn{1}{c}{7} \\
Tolerante \\
SM/totale \\
SM
\end{tabular} & \begin{tabular}{l}
\multicolumn{1}{c}{8} \\
FA/perify- \\
ton
\end{tabular} & \begin{tabular}{l}
\multicolumn{1}{c}{9} \\
Soortenrijk- \\
dom \\
SM+FLM
\end{tabular} & $\begin{array}{l}\text { Totale } \\
\text { score }\end{array}$ & EQR \\
\hline $\begin{array}{l}\mathrm{C} 1 \\
\mathrm{C} 2\end{array}$ & & & & & & & & & & & \\
\hline RK & 2 & 2 & 2 & 0 & 2 & & & & & 8 & 0.16 \\
\hline S1 & 0 & & & 0 & & & & & & 0 & 0.00 \\
\hline S4 & 2 & & & 6 & & & & & & 8 & 0.40 \\
\hline W2 & 8 & 10 & 10 & 6 & 10 & & & & & 44 & 0.88 \\
\hline $\mathrm{TrBr}$ & 2 & 10 & 10 & 0 & 10 & 2 & 0 & 0 & 2 & 36 & 0.40 \\
\hline WPk1 & 10 & 10 & 10 & 10 & 10 & 6 & 2 & 2 & 10 & 70 & 0.78 \\
\hline Wtml & 10 & 10 & 10 & 2 & 10 & 6 & 0 & 10 & 10 & 68 & 0.76 \\
\hline
\end{tabular}

In de Woluwe (EQR=0.88), WPk1 (EQR=0.78) en Wtml (EQR=0.76) werd het goed ecologisch potentieel bereikt. De bedekking van submerse soorten in Wtml lag laag, mogelijk mede door een bloei van Synura in juni, hoewel er verschillende soorten werden aangetroffen. De tijdelijke drooglegging en biomanipulatie van deze vijver na 2013 lijkt niet meteen te resulteren in abundante groei van macrofyten, ondanks de verbeterde EQR. Vermoedelijk heeft Wtml wel het potentieel om opnieuw uit te groeien tot een van de meest waardevolle vijvers in het gewest $(\mathrm{Wtml}$ werd in een recent verleden voorgedragen als referentie voor ecologische kwaliteit van vijvers in het bekken; De Backer et al. 2011). TrBr scoort door de afwezigheid van submerse macrofyten maar extensieve oevervegetatie matig ( $E Q R=0.40)$.

Een geografisch overzicht van de EQR op basis van macrofyten wordt gegeven in Figuur 13.

\subsubsection{Habitattypes Natura 2000}

Net als in 2013 en 2014 (Van Onsem \& Triest 2015) werd in WPk1 een gedegradeerde toestand van habitattype H3150 aangetroffen, dankzij de aanwezigheid van twee relictsoorten en meer dan vier begeleidende soorten. Sleutelsoorten ontbraken (Tabel 10).

De in 2016 geobserveerde kranswiersoorten kwamen voor in te lage abundantie om gecatalogeerd te worden als habitat H3140. 
Tabel 10: Categorisatie van de bestudeerde vijvers in functie van aquatische habitattypes van de Habitatrichtlijn.
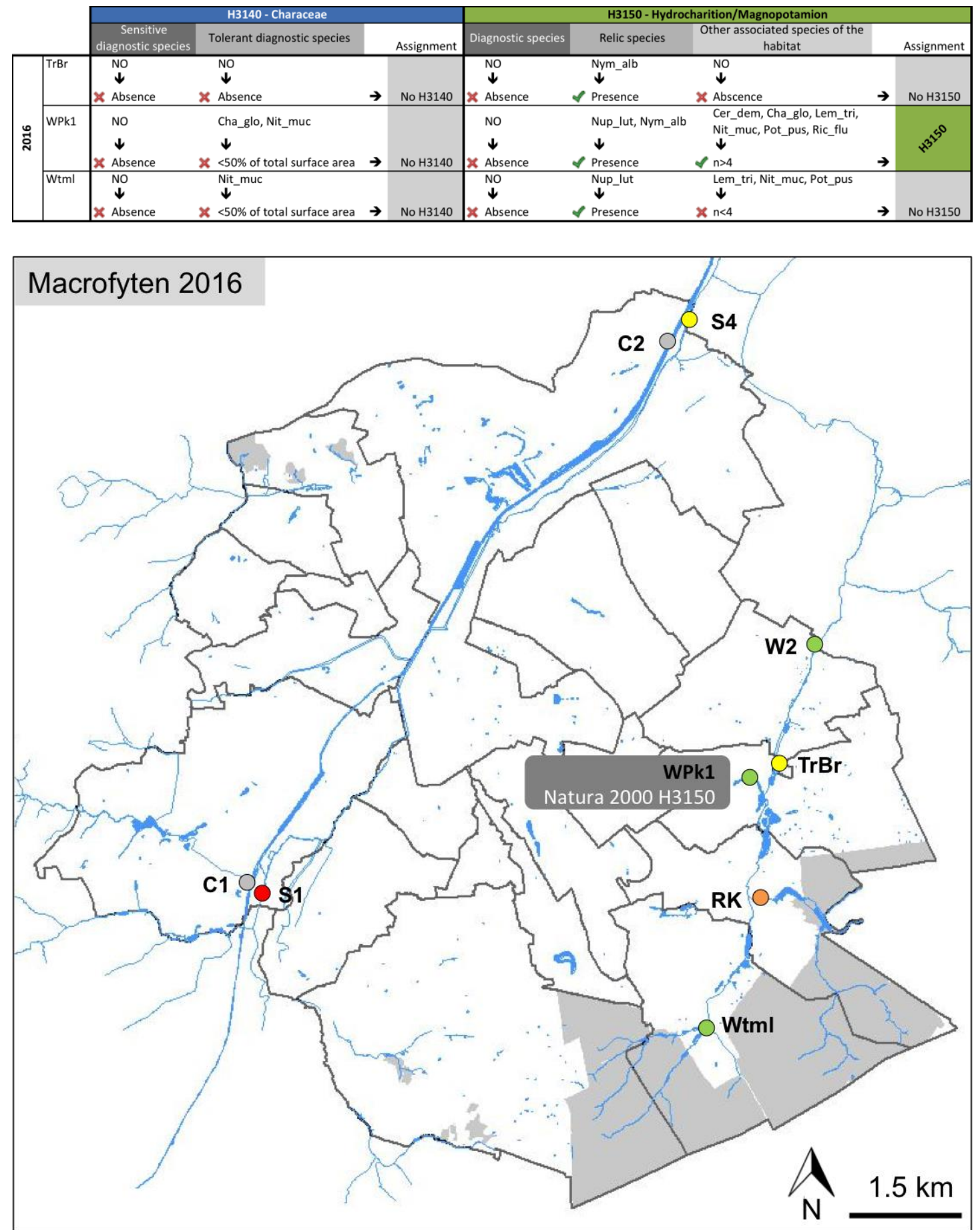

Figuur 13: Ruimtelijk overzicht van de kwaliteit voor het onderdeel macrofyten. WPk1 bevat het habitattype 3150 in gedegradeerde toestand. 


\section{Macroinvertebraten}

\subsection{Statusbeoordeling}

Er werden geen wijzigingen uitgevoerd ten opzichte van het vorige protocol. In de waterlopen (inclusief kanaal) wordt gebruik gemaakt van de index IBGN. De vijvers worden beoordeeld op basis van de MMIF (Gabriels et al. 2010).

\subsection{Methodologie}

\subsubsection{Staalname}

Macroinvertebraten werden in kanaal en Zenne ingezameld met behulp van artificiële substraten (Figuur 14). Een stuk vogelnet met maaswijdte van $1 \mathrm{~cm}^{2}$ werd gevuld met $3 \mathrm{~L}$ baksteengruis (cf. De Pauw 1989) en $1 \mathrm{~L}$ kalkstenen met variabele vorm en grootte. Om het substraatvolume te uniformiseren, werd de waterverplaatsing van de stenen gecontroleerd in een emmer water. Het net werd dichtgeknoopt en met plastic snelbinders bevestigd op een metalen frame met maaswijdte $0.5 \mathrm{~cm}$ en een oppervlakte van 0.5 bij $0.5 \mathrm{~m}$.

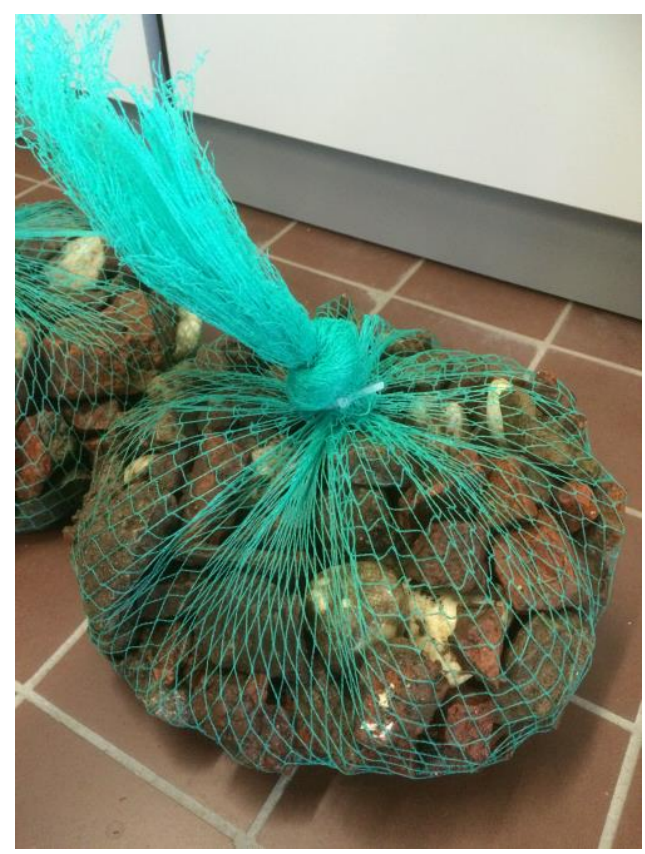

Figuur 14: Artificieel substraat voor macroinvertebraten

Een kooi met grove stenen en grotere maaswijdte zoals gebruikt tijdens vorige campagnes werd niet meer nodig geacht, omwille van het beperkte kolonisatiesucces. Grotere macroinvertebraten worden met succes ingezameld met behulp van het metalen gaas. 
Aan de vier hoeken van het metalen frame werd nylontouw bevestigd dat op een halve meter hoogte samengeknoopt werd. Het substraat werd aan deze knoop met nylontouw tot op de bodem van de staalnamelocaties neergelaten. Aan elke site werden drie replica's uitgehangen. De kolonisatieperiode bedroeg vijf weken.

In de kleinere waterlopen (RK en W2) en in de vijvers werd bemonsterd met en waadpak en een D-vormig kicknet met maaswijdte $0.5 \mathrm{~mm}$. Gedurende drie minuten werd langsheen een transect of verschillende zones gesleept en gestampt, zodanig dat alle aanwezige aquatische milieus werden bemonsterd.

\subsubsection{Identificatie}

Stalen werden gezeefd en bewaard in $70 \%$ ethanol. Identificatie gebeurde tot op het voor de verschillende indices benodigde taxonomische niveau (Josens in Van Onsem et al. 2012, Gabriels 2010). Gammaridae werden gedetermineerd tot op genusniveau (Dobson 2012) om de distributie van (eventueel invasieve) exoten binnen deze groep in kaart te brengen.

\section{Resultaten}

De macroinvertebratengemeenschap in het kanaal wordt op beide plaatsen gedomineerd door exoten van Pontokaspische, Aziatische en Noord-Amerikaanse origine (zie Appendix 2), die zich makkelijk verspreiden wanneer hydrologische connecties tot stand komen. De kwaliteit in 2016 was matig (EQR=0.63 op beide plaatsen; Tabel 11). Het kanaal in Anderlecht (C1) bevindt zich al langere tijd in een matige toestand, terwijl aan de noordgrens de kwaliteit eerder lijkt te schommelen langsheen de grens tussen een goede en matige toestand. Potentiële knelpunten in het kanaal zijn de grote diepte en troebelheid, sterke golfslag en het ontbreken van macrofyten of andere elementen die bijdragen aan een verhoogde nichediversiteit. Een gedeeltelijke oplossing is het voorzien van ondiepe, afgeschermde randzones (Boedeltje et al. 2001).

In de Zenne bleek de kwaliteit onvoldoende (EQR=0.40 in S1) of slecht (EQR=0.20 in S4). Zeker ter hoogte van het noordelijke rioolwaterzuiveringsstation (de substraten werden uitgehangen op de site van Aquiris) is de toestand voor macroinvertebraten zwak. Onder meer de grote hoeveelheid (organisch) slib op de bedding en de afwezigheid van meandering maken dit deel van de Zenne duidelijk ongeschikt voor vestiging van gevoeligere soorten.

In de Roodkloosterbeek werd op gebied van macroinvertebraten een goede toestand vastgesteld (EQR $=0.82$ ), mede mogelijk gemaakt door de wellicht goede chemische waterkwaliteit (ondanks een hoge TDI-waarde voor diatomeeën). De Woluwe scoorde daarentegen matig ( $E Q R=0.64)$, net als in 2013. De concentratie aan omnivore, invasieve kreeften (Orconectes limosus) ligt hier vermoedelijk vrij hoog (cf. elektrische visvangst), en zou een hindernis kunnen zijn. 
Tabel 11: Resultaten van de berekening van EQR op basis van IBGN voor kanaal en waterlopen.

\begin{tabular}{|c|c|c|c|c|c|c|}
\hline LOCATIE & C1 & $\mathrm{C} 2$ & RK & S1 & S4 & W2 \\
\hline DATUM STAALNAME & $29-06-16$ & $29-06-16$ & $28-06-16$ & $29-06-16$ & $29-06-16$ & $28-06-16$ \\
\hline Aantal taxa globaal & 12 & 12 & 21 & 12 & 10 & 16 \\
\hline Aantal taxa cf. IBGN & 12 & 10 & 17 & 9 & 6 & 15 \\
\hline Diversiteitsklasse (CD) & 4 & 4 & 6 & 3 & 2 & 5 \\
\hline Indicatortaxa & $\begin{array}{c}\text { Gammaridae/ } \\
\text { Mollusca }\end{array}$ & $\begin{array}{c}\text { Gammaridae/ } \\
\text { Mollusca }\end{array}$ & Psychomiidae & $\begin{array}{c}\text { Gammaridae/ } \\
\text { Mollusca }\end{array}$ & $\begin{array}{l}\text { Oligochaeta/Hir } \\
\text { udinea/Asellida } \\
\text { e/Chironomidae }\end{array}$ & Hydropsychidae \\
\hline Indicatorgroep (GI) & 2 & 2 & 4 & 2 & 1 & 3 \\
\hline Score IBGN & 5 & 5 & 9 & 4 & 2 & 7 \\
\hline MEP & 8 & 8 & 11 & 10 & 10 & 11 \\
\hline$E Q R_{I B G N}$ & 0.63 & 0.63 & 0.82 & 0.40 & 0.20 & 0.64 \\
\hline
\end{tabular}

Twee van de drie vijvers (WPk1 en Wtml) bevatten een soortdiverse en relatief waardevolle macroinvertebraten-gemeenschap (EQR $=0.75$ en 0.80 , respectievelijk; Tabel 12). TrBr haalde slechts een matige kwaliteit (EQR=0.55).

Figuur 15 geeft een overzicht van de EQR voor macroinvertebraten in het Brussels Hoofdstedelijk Gewest.

Tabel 12: Resultaten van de berekening van EQR op basis van MMIF voor vijvers.

\begin{tabular}{|c|c|c|c|c|c|c|}
\hline \multirow{3}{*}{$\begin{array}{l}\text { LOCATIE } \\
\text { DATUM STAALNAME }\end{array}$} & $\mathrm{TrBr}$ & & WPk1 & & Wtml & \\
\hline & $28-06-16$ & & $28-06-16$ & & $28-06-16$ & \\
\hline & Waarde & Score & Waarde & Score & Waarde & Score \\
\hline Taxonrijkdom & 23 & 3 & 27 & 4 & 30 & 4 \\
\hline Aantal EPT & 1 & 1 & 3 & 2 & 5 & 4 \\
\hline Aantal sensitieve taxa excl. EPT & 4 & 2 & 7 & 3 & 7 & 3 \\
\hline Shannon-index & 1.63 & 2 & 2.33 & 3 & 1.72 & 2 \\
\hline Gemiddelde tolerantiescore & 4.57 & 3 & 4.81 & 3 & 4.90 & 3 \\
\hline Som & & 11 & & 15 & & 16 \\
\hline $\mathrm{EQR}_{\mathrm{MMIF}}$ & & 0.55 & & 0.75 & & 0.80 \\
\hline
\end{tabular}




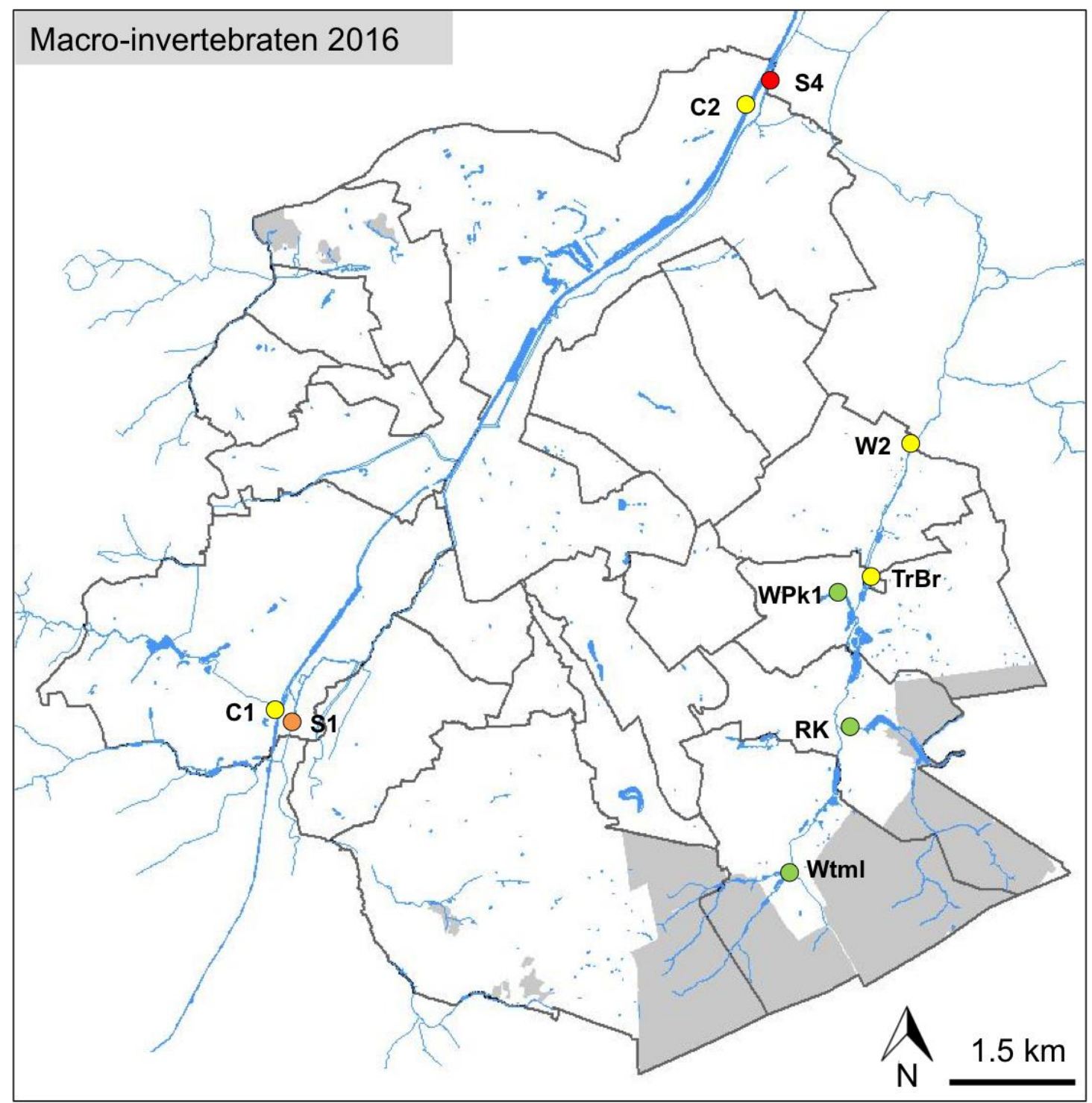

Figuur 15: Ruimtelijk overzicht van de kwaliteit voor het onderdeel macro-invertebraten. 
Jan Breine

\section{Inleiding}

De Kaderrichtlijn Water (EU Water Framework Directive, WFD, 2000) is sinds 22 oktober 2000 van kracht. Deze richtlijn had als doel om in 2015 een 'goede toestand' te bereiken in alle Europese waters. In Vlaanderen en Brussel werd uitstel aangevraagd tot 2021 en 2027 om de kwaliteit van het grond- en oppervlaktewater op een goed niveau te krijgen. De deadline voor het realiseren van een 'goede toestand' is dus uiterlijk 2027. Voor de verschillende ecologische kwaliteitselementen werden beoordelingssystemen ontwikkeld zodat de toestand van de oppervlaktewaters kan worden beoordeeld.

Vis is één van de kwaliteitselementen en voor de Kaderrichtlijn Water (KRW) moet er voor de oppervlaktewaters (rivieren en meren) gerapporteerd worden over de samenstelling, abundantie en leeftijdsopbouw van de visgemeenschap. Daarenboven moet er voor elk type oppervlakte water en elk kwaliteitselement een referentie beschreven worden. De voordelen en nadelen van het gebruik van vissen als kwaliteitsinstrument werden uitvoerig in vorige rapportages geduid (Van Tendeloo et al., 2004; Triest et al., 2008; Van Onsem et al., 2014).

Voor de visfauna in een natuurlijk waterlichaam betekent dit dat de samenstelling en abundantie van de soorten geheel of vrij geheel overeenkomen met de onverstoorde staat. Verder dienen de typespecifieke, voor verstoring gevoelige, soorten aanwezig te zijn en de leeftijdsopbouw mag slechts weinig tekenen van verstoring vertonen. Voor een sterk veranderd of kunstmatig waterlichaam wordt een 'Maximaal' en 'Goed Ecologisch Potentieel' beschreven (MEP en GEP).

Voor het Maximaal Ecologisch Potentieel moeten de waarden voor de kwaliteitselementen zoveel mogelijk normaal zijn in vergelijking tot het onverstoorde, meest vergelijkbare type, oppervlaktelichaam van de categorie waarin het hoort nl. rivieren of meren. Terwijl voor het Goed Ecologisch Potentieel lichte veranderingen in de waarden van de kwaliteitselementen, ten opzichte van de waarden bij maximaal ecologisch potentieel, toegestaan zijn.

Op basis van deze referenties kunnen per type water maatlatten ontwikkeld worden. Elke maatlat bestaat uit deelmaatlatten of metrieken, die bepaalde aspecten van de visstand beoordelen. Op elke deelmaatlat kan een score tussen 0 en 1 gegeven worden. De som van de berekende scores wordt omgerekend naar een ecologische kwaliteit ratio (EQR). Deze EQR, met gelijke klasse intervallen, geeft een appreciatie van de ecologische kwaliteit: slecht, ontoereikend, matig, GEP of MEP.

Bij het ontwikkelen van de maatlatten is het van groot belang dat er een gestandaardiseerde methodologie ontwikkeld wordt en dit zowel wat betreft de staalname als wat betreft het vastleggen van de grenswaarden van de deelmaatlatten. 
In Van Onsem et al. (2014) werden voor de verschillende types waterlichamen in het Brussels Hoofdstedelijk Gewest het GEP, het MEP en referenties beschreven. De staalnamemethode bleef ook in 2016 onveranderd (CEN, 2002; Van Tendeloo et al., 2004). In 2013 werd de index voor kanalen (en meren) aangepast. In 2013 werden de aangepaste IBI voor kanalen (en meren) op de gegevens van 2004, 2007 en 2013 berekend. We gebruiken dezelfde indices voor de 2016 data van kanalen en rivieren.

We bespreken in dit hoofdstuk de resultaten van de verschillende viscampagnes in 2016. Deze resultaten worden vergeleken met vorige vangstresultaten. We bespreken de trends in het visbestand op basis van viscampagnes uitgevoerd in hetzelfde seizoen. We vergelijken de IBIB waarden voor de verschillende campagnes over de jaren heen. Door het beperkte budget werden de vijvers ditmaal niet bemonsterd.

\section{Methodologie}

De gehanteerde vismethodes werden al toegelicht in vorige campagnes. We geven ze hier kort terug als geheugensteun.

\subsubsection{Rivieren}

Net zoals de andere kwaliteitselementen kunnen vissen op verschillende manieren gemonitord worden. CEN (2002) geeft de richtlijnen voor het bemonsteren met elektriciteit (in rivieren). Deze richtlijnen werden ook overgenomen door de Europese lidstaten (Breine et al., 2005). Er zijn nog steeds geen documenten voor het gebruik van fuiken en sleepnet verschenen. Bij het elektrisch vissen wordt er in het water een elektrisch veld opgewekt tussen de anode en kathode pool. De grootte van het veld wordt bepaald door de stroomsterkte en het type elektroden (Beaumont et al., 2002). Een vis in het elektrisch veld is onderhevig aan elektrotaxis (aantrekking) en/of elektronarcose (verdoving). De efficiëntie wordt beïnvloed door de spanning, de watertemperatuur en de grootte van de vis (Regis et al., 1981). Het voordeel van de elektrische visvangst in rivieren boven het gebruik van fuiken ligt in het feit dat deze methode minder soortselectief is. Verder kan men de efficiëntie bij het elektrisch vissen in grote mate constant houden als men steeds met dezelfde personen werkt. Deze methode laat ons ook toe om vissen tussen waterplanten en holle oevers weg te vissen. Tenslotte treedt er ook zeer weinig vissterfte op bij het juist hanteren van deze methode. Ongewenste gevolgen van het elektrisch vissen zoals stress, kwetsuren en soms sterfte kunnen wel voorkomen bij te hoge stroomsterktes (Snyder, 2003). Verder zijn er nog factoren waar we rekening mee moeten houden. Zo zal een te grote geleidbaarheid van het water de vangstefficiëntie drastisch doen verminderen. In een snelstromend water bestaat de kans dat verdoofde vissen niet opgemerkt worden. Goffaux et al. (2003) bestudeerden verschillende methodes voor het bekomen van visgemeenschap data voor de ontwikkeling van een visindex van het Maasbekken. Hierbij werden boomkor, kieuwnet en elektrische vangsttechnieken in de Maas met elkaar 
vergeleken. Voor de ontwikkeling van een visindex werd door deze auteurs besloten om alleen de elektrische vangstgegevens te gebruiken. Naargelang de beoogde resultaten wordt een locatie één of tweemaal afgevist (CEN, 2002, Penczak, 2011). Soms wordt de rivier afgespannen met een net voor het voorkomen van ontsnappingen (Kruse et al., 1998). Deze methode is echter niet praktisch vooral bij sterke stroming.

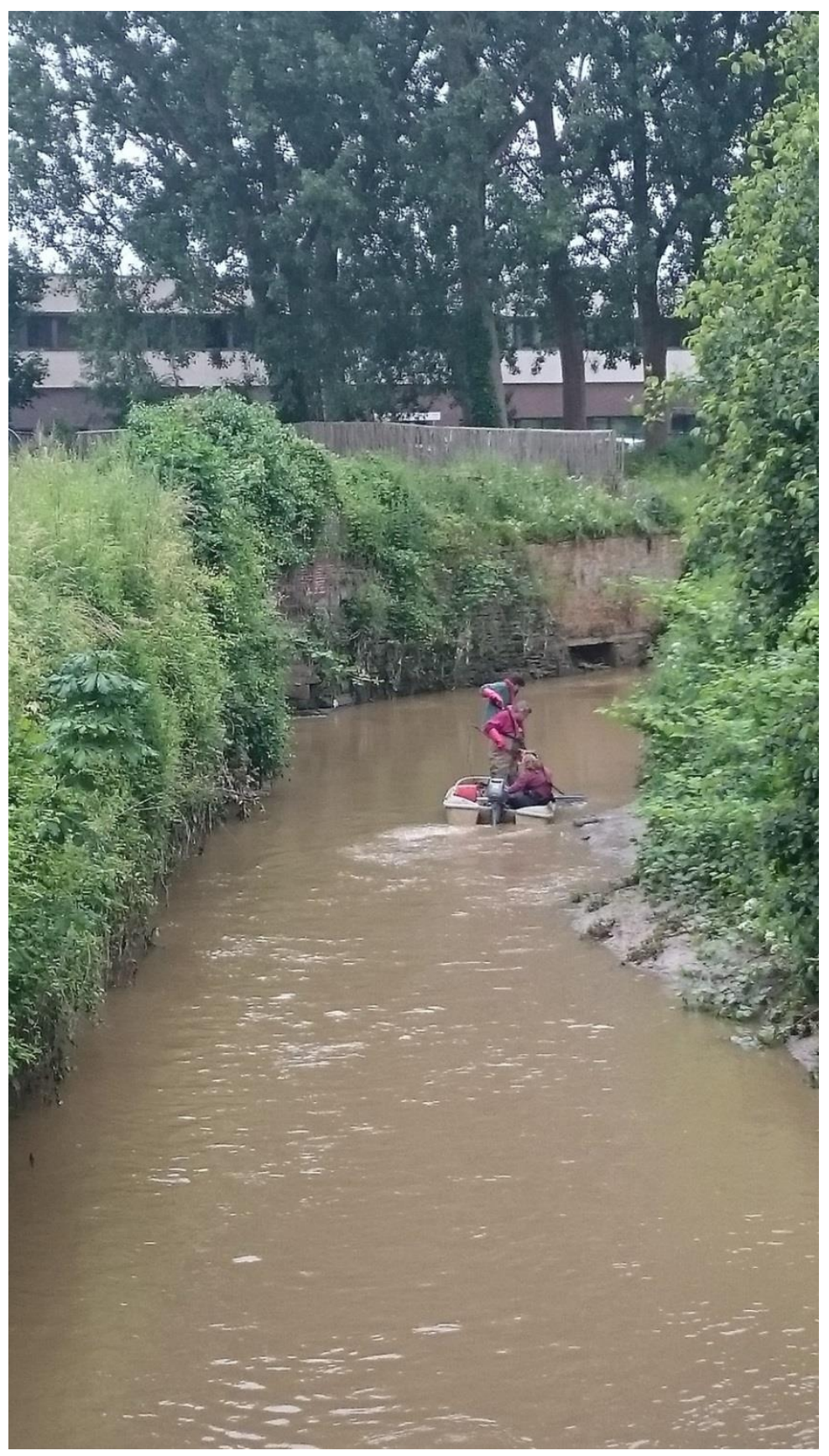

Figuur 16: Elektrische afvissing op de Zenne.

Voor grote rivieren ( $>30 \mathrm{~m}$ breed) worden vaak verschillende technieken gecombineerd (Meffe \& Berra, 1988; Pegg \& Pierce, 2002) of alleen sleepnetten gebruikt (Angermeier \& Smogor, 1994). Immers bij dieptes van meer dan $2 \mathrm{~m}$ wordt 
het moeilijk om met elektriciteit te vissen (De Leeuw et al., 2007). De combinatie van verschillende methodes maakt het niet makkelijker om een maatlat te ontwikkelen.

In Van Tendeloo et al. (2004) stelden we voor om voor rivieren in het Brussels Gewest één methode te gebruiken. Het gebruikte toestel is van het type DEKA 7000 gevoed door een $5 \mathrm{~kW}$ generator met een regelbare spanning variërend van 300 tot $500 \mathrm{~V}$. De stroomstootfrequentie is $480 \mathrm{~Hz}$. Er werden telkens twee elektroden gebruikt. Alle gevangen vissen werden op soort geïdentificeerd, geteld en gewogen. Van elke vis wordt de lengte gemeten. De verzamelde gegevens worden in een databank opgeslagen.

\subsubsection{Kanalen}

De toegepaste technieken zijn identiek als in vorige campagnes. Per locatie plaatsten we vier fuiken gedurende 48 uur. Verder werd iedere oever elektrisch bemonsterd met twee elektrodes over een afstand van $250 \mathrm{~m}$. Ook hier werden alle gevangen vissen op soort geïdentificeerd, geteld en gewogen. Van elke vis maten we de lengte. De verzamelde gegevens sloegen we op in een databank.

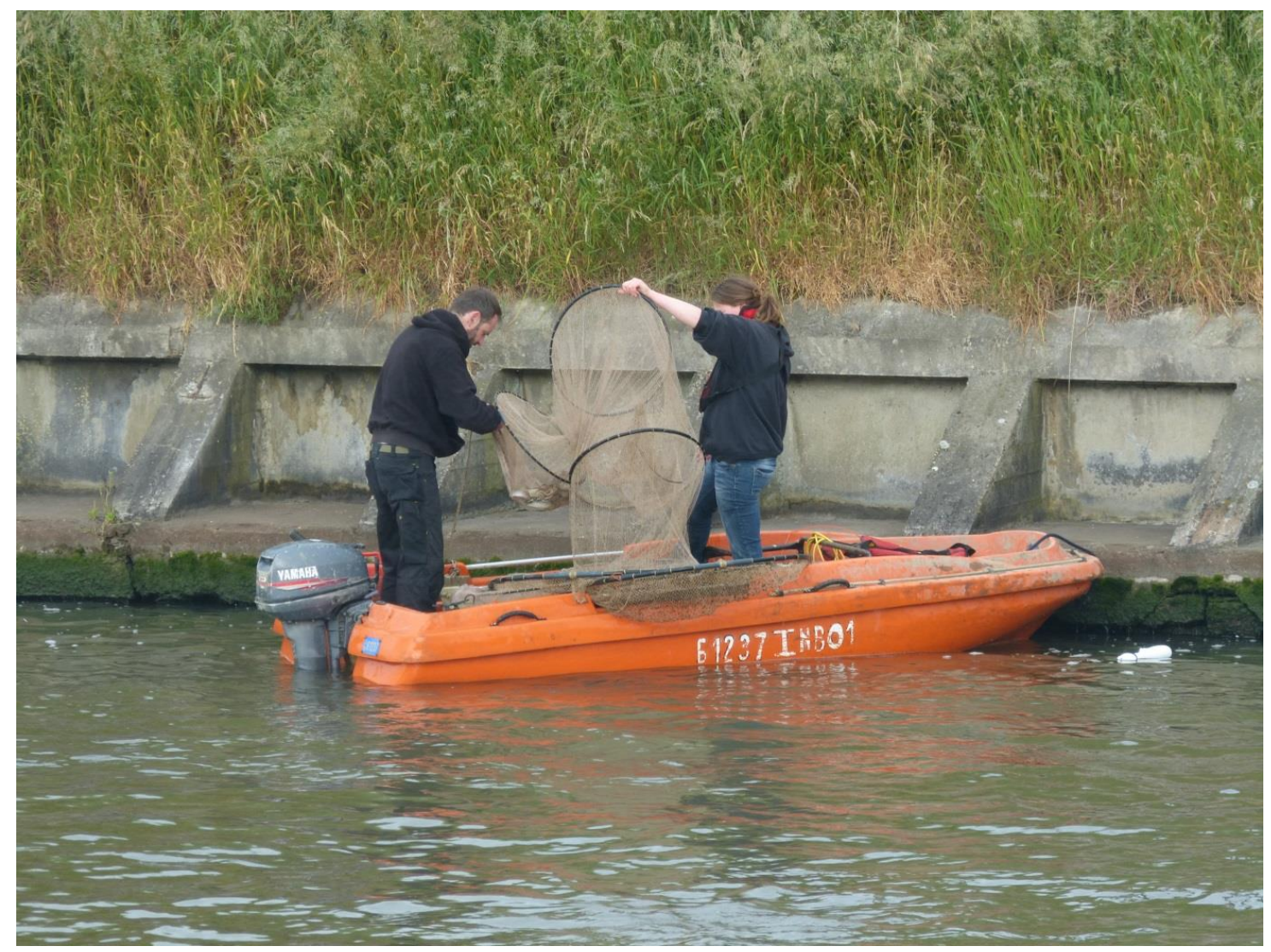

Figuur 17: Het ophalen van fuiken op het kanaal Brussel Charleroi (Foto Stijn Van Onsem). 


\subsubsection{Besluit}

Er bestaat een grote verscheidenheid in technieken voor het verkrijgen van visstand gegevens. Voor het bepalen van de ecologische kwaliteit van rivieren op basis van gegevens over de vissamenstelling gebruiken we de methode voorgesteld in Van Tendeloo et al. (2004). Deze methode wordt toegepast in Vlaanderen en Wallonië en stemt overeen met deze beschreven in het CEN document. Voor het bepalen van de visstand in kanalen gebruiken we twee technieken waarbij de resultaten voor het bereken van de index apart worden verwerkt.

\subsection{Toegepaste methode}

\subsubsection{Rivieren}

\section{Selectie van locatie:}

De geselecteerde locatie moet representatief zijn, binnen het segment, wat betreft de habitat types en diversiteit, landgebruik en intensiteit van antropogene invloed. Een rivier segment is bepaald als:

$1 \mathrm{~km}$ voor rivieren met een bekken $<100 \mathrm{~km}^{2}$

$5 \mathrm{~km}$ voor rivieren met een bekken tussen $100-1000 \mathrm{~km}^{2}$

$10 \mathrm{~km}$ voor rivieren met een bekken $>1000 \mathrm{~km}^{2}$

Methode:

Tabel 13 en Tabel 14 geven de details weer van de toe te passen methode voor het verkrijgen van visstand gegevens bruikbaar voor het bepalen van de ecologische kwaliteit van de waterloop.

Tabel 13: Methode in overeenkomst met CEN (2002) voor doorwaadbare rivier (< 0,7 m diep; Woluwe en Roodkloosterbeek).

\begin{tabular}{|l|l|}
\hline Bron spanning: & DC of PDC \\
\hline Aantal anodes: & Eén anode per 2 m rivierbreedte* \\
\hline Aantal schepnetten: & $\begin{array}{l}\text { Elke anode wordt gevolgd door één of twee } \\
\text { schepnet dragers (maaswijdte } 6 \quad \mathrm{~mm} \\
\text { maximum) en één container voor het } \\
\text { stockeren van de gevangen vis. }\end{array}$ \\
\hline Aantal passages: & Eén passage per afvissing \\
\hline Wanneer: & Tijdens dag \\
\hline Lengte locatie: & $\begin{array}{l}10 \text { maal de rivierbreedte met een minimum } \\
\text { lengte van } 100 \mathrm{~m}\end{array}$ \\
\hline Oppervlakte locatie: & $\begin{array}{l}\text { Rivier breedte }<15 \mathrm{~m} \text { : totale oppervlakte } \\
\text { Rivier breedte }>15 \mathrm{~m} \text { : verschillende locaties } \\
\text { worden geselecteerd en bemonsterd binnen }\end{array}$ \\
\hline
\end{tabular}




\begin{tabular}{|l|l|}
\hline & $\begin{array}{l}\text { de locatie (al of niet continu), met een } \\
\text { minimum van } 1000 \mathrm{~m}^{2}\end{array}$ \\
\hline Richting: & Stroomopwaarts \\
\hline Beweging: & $\begin{array}{l}\text { Traag, de totale habitat oppervlakte } \\
\text { bestrijken met een zwaaiende beweging } \\
\text { waarbij getracht wordt de vissen uit hun } \\
\text { schuilplaats te drijven }\end{array}$ \\
\hline Stop net: & Wanneer toepasbaar \\
\hline
\end{tabular}

* naar Belpaire et al., 2000. Dit betekent dat er intensiever gevist wordt dan voorgesteld door de CEN.

Tabel 14: Methode in overeenkomst met CEN (2002) voor diepere rivieren (> 0,7 $\mathrm{m}$ diep; Zenne en kanaal).

\begin{tabular}{|l|l|}
\hline Bron spanning: & DC of PDC \\
\hline Aantal anodes: & Minimum 2 anodes \\
\hline Aantal passages: & Eén passage per afvissing \\
\hline Wanneer: & Tijdens dag \\
\hline Lengte locatie: & 10 maal de rivierbreedte met een minimum lengte van $100 \mathrm{~m}$ \\
\hline Oppervlakte locatie: & $\begin{array}{l}\text { Beide oevers van de rivier of een aantal sub samples } \\
\text { afhankelijk van de habitat diversiteit met een minimum van } \\
1000 \mathrm{~m}^{2}\end{array}$ \\
\hline Richting: & $\begin{array}{l}\text { Bij normale stroomsnelheid: stroomafwaarts zodat het habitat } \\
\text { goed bemonsterd kan worden } \\
\text { Hoge stroomsnelheid: stroomopwaarts } \\
\text { Bijna stilstaand: geen richting bepaald }\end{array}$ \\
\hline Beweging: & $\begin{array}{l}\text { Traag, de totale habitat oppervlakte bestrijken met een } \\
\text { zwaaiende beweging waarbij getracht wordt de vissen uit hun } \\
\text { schuilplaats te drijven }\end{array}$ \\
\hline Stop net: & Wanneer toepasbaar \\
\hline
\end{tabular}

\subsubsection{Kanalen}

Selectie van locatie:

De geselecteerde locatie moet representatief zijn, binnen het segment, wat betreft de habitat types en diversiteit, landgebruik en intensiteit van antropogene invloed. Een kanaal segment is bepaald als $5 \mathrm{~km}$.

Methode:

Voor beide technieken wordt een boot gebruikt.

Elektrisch: langs de oever als deze schuilplaatsen bevat en het kanaal daar niet dieper is dan één meter. We gebruiken hier de methode zoals voorgesteld in Tabel 14. Voor eventuele interkalibratie stellen we de lengte van de locatie vast op $250 \mathrm{~m}$ langs beide oevers (overeen te stemmen met andere Europese landen). De breedte van het transect is 2,5 meter. Voor het verwerken van de gegevens worden de 
resultaten voor beide oevers samengevoegd. De EQR waarde wordt per locatie gegeven en is berekend op basis van de elektrische en fuikvangsten.

Fuiken: langs de oevers zodat ze de scheepvaart niet bemoeilijken. Er worden op iedere locatie, per oever, twee dubbele schietfuiken (Figuur 18) geplaatst voor een periode van 48 uur. Elke schietfuik bestaat uit twee fuiken van 7,7 m lengte, waartussen een net van $11 \mathrm{~m}$ gespannen is. Dat net is bovenaan voorzien van vlotters. Onderaan bevindt zich een loodlijn. Vissen die tegen het overlangse net zwemmen, worden naar een van de fuiken geleid. De twee fuiken (type 120/90) zijn opgebouwd uit een reeks hoepels waarrond een net (maaswijdte $1 \mathrm{~cm}$ ) bevestigd is. Aan de ingang van de fuik staat de grootste hoepel (diameter $90 \mathrm{~cm}$ ). Deze is onderaan afgeplat $(120 \mathrm{~cm}$ breed) zodat de hele fuik recht blijft staan. Naar achter toe worden de hoepels kleiner. Aan het uiteinde is de maaswijdte $8 \mathrm{~mm}$. In de fuik bevinden zich een aantal trechtervormige netten waarvan het smalle uiteinde naar achter is bevestigd. Eenmaal de vissen een trechter gepasseerd zijn, kunnen ze niet meer terug. Helemaal achteraan wordt de fuik geopend en leeggemaakt.

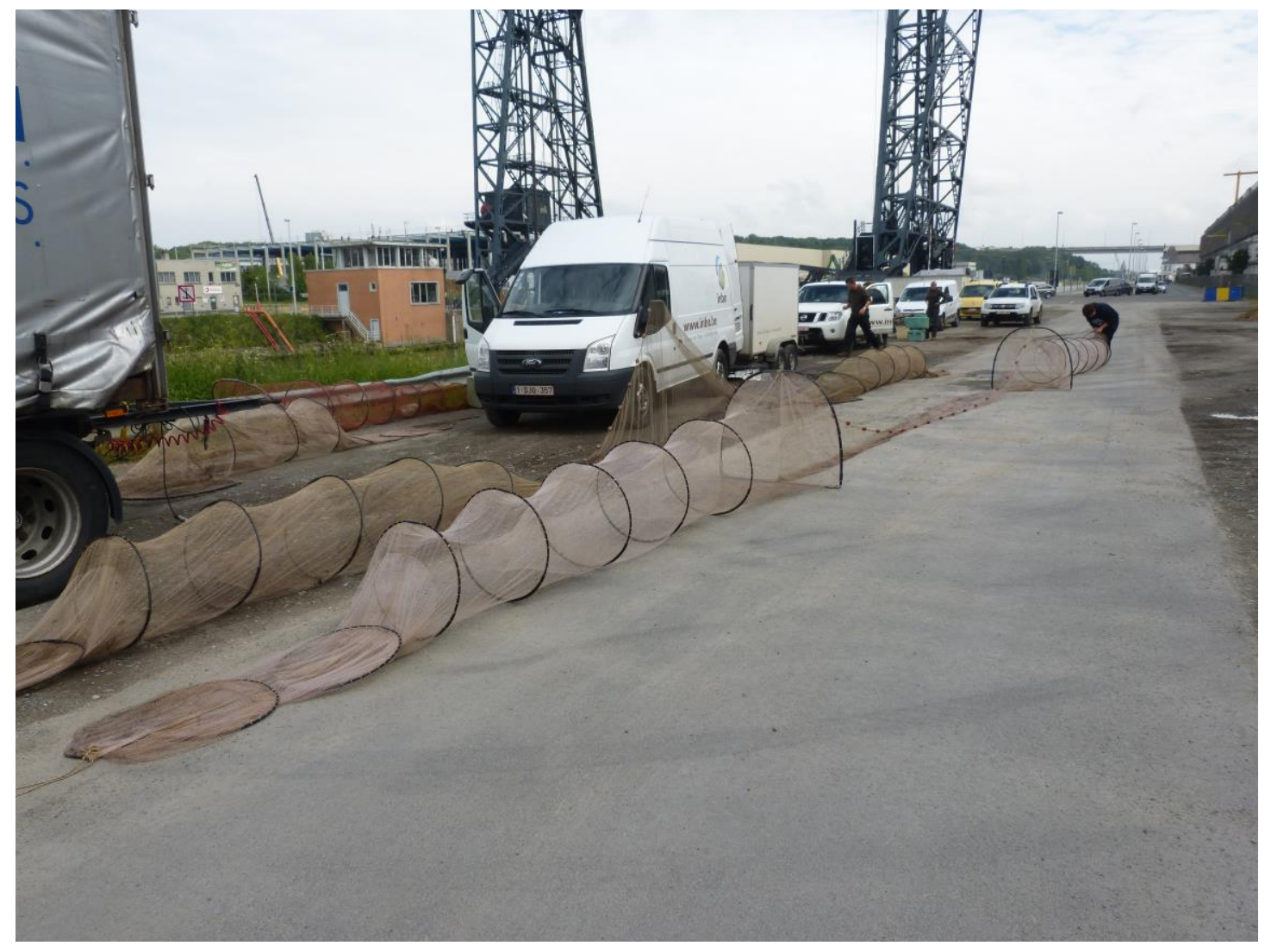

Figuur 18: Schietfuiken gebruikt in het kanaal (C2).

\subsection{Beoordelingssystemen}

Zoals vermeld in Triest et al. (2008) bestaan er nationaal verschillende beoordelingssystemen of indices voor rivieren gebaseerd op visgegevens. 
Voor de Zenne, Woluwe en Roodkloosterbeek gebruiken we de indices zoals beschreven in Triest et al. (2008). Dat betekent dat we voor de Zenne de index voor grote rivieren gebruiken. Voor de Woluwe en Roodkloosterbeek de index voor kleine beken.

Voor de kanalen beschikken we nationaal over een index beschreven in Van Onsem et al. (2014).

De maatlatten voorgesteld in 2013 blijven hier ook van kracht. Dat laat ons ook toe om de resultaten van de campagnes uitgevoerd in 2004, 2007 en 2013 te vergelijken met deze van 2016.

De indices bestaan uit verschillende metrieken. Een metriek is een parameter die de toestand beschrijft van een bepaalde eigenschap van de visgemeenschap. Deze parameters zijn gevoelig voor verstoring. Voor elke metriek worden grenswaarden bepaald ten opzichte van een referentie. Deze grenswaarden werden bepaald op basis van historische data, expert kennis, statistische analyses of een combinatie van deze. De som van de berekende scores geeft de uiteindelijke indexwaarde. Deze wordt omgerekend naar een Ecologische Kwaliteit Ratio (EQR) met gelijke klasse intervallen. Deze EQR wordt tenslotte vertaald naar een appreciatieklasse of integriteitklasse.

De som van de scores gedeeld door het aantal gebruikte metrieken geeft de index waarde. De Ecological Quality Ratio wordt berekend door de IBI score (Index voor Biotische Integriteit) om te zetten naar een schaal van 0 tot 1 . Daartoe wordt de volgende formule gebruikt:

$T E Q R=L V T E Q R+(O E Q R-L V O E Q R) /(U V O E Q R-L V O E Q R) * 0.25$

T staat voor de getransformeerde EQR en O voor de originele EQR (Indexwaarde delen door aantal metrieken). UV en LV staan voor de bovengrens en ondergrens waarde van de integriteitsklasse.

\section{Referentietoestand voor vissen}

\subsubsection{Inleiding}

De referentietoestand van vissen in een natuurlijk waterlichaam moet volgens de $\mathrm{KRW}$ voldoen aan de volgende criteria:

- de samenstelling en abundantie van de soorten komt geheel of vrij geheel overeen met de onverstoorde staat.

- de type-specifieke, voor verstoring gevoelige, soorten zijn aanwezig

- de leeftijdsopbouw vertoont slechts weinig tekenen van verstoring

Zoals al vermeld spreken we voor een sterk veranderd of kunstmatig waterlichaam over een Maximaal of Goed Ecologisch Potentieel.

Voor het bepalen van een potentieel zijn er verschillende benaderingen mogelijk. 
Volgens Hughes (1995) heeft de combinatie van regionale referentiesites en historische data, geïnterpreteerd door gebruik van lineaire modellen en professioneel beoordeeld de meeste kans van slagen. Daar we hier met sterk veranderde waterlichamen te maken hebben zullen we een goed of maximaal ecologisch potentieel beschrijven naargelang het waterlichaam al of niet kunstmatig is.

\subsubsection{Rivieren}

Voor de rivieren in het Brussels Gewest beschikken nog steeds over een beperkt aantal gegevens. We blijven de referentie houden zoals beschreven in Triest et al. (2008).

We stellen wel voor om deze referenties aan te passen eenmaal er voldoende campagnes zijn uitgevoerd. Dat is vooral belangrijk voor de Woluwe en Roodkloosterbeek gezien de referenties gebaseerd zijn op recente vangstgegevens. Per waterloop hebben we toch een minimum van 15 campagnes nodig. Met voldoende data kunnen statistische analyses de grenswaarden van de metrieken bijgesteld worden. Voor de Zenne is misschien ook een aanpassing nodig (zie verder 6.9.1).

Tabel 15: Vissoorten in de referentielijst van grote rivieren (Zenne).

\begin{tabular}{ll}
\hline Referentie soort & \multicolumn{1}{c}{ Wetenschappelijke naam } \\
\hline baars & Perca fluviatilis (Linnaeus, 1758) \\
beekforel & Salmo trutta (Linnaeus, 1758) \\
bermpje & Gymnocephalus cernua (Linnaeus, 1758) \\
bittervoorn & Rhodeus sericeus (Pallas, 1776) \\
blankvoorn & Rutilus rutilus (Linnaeus, 1758) \\
brasem & Abramis brama (Linnaeus, 1758) \\
bot & Platichthys flesus (Linnaeus, 1758) \\
driedoornige stekelbaars & Gasterosteus aculeatus (Linnaeus, 1758) \\
giebel & Carassius gibelio (Bloch, 1782) \\
karper & Cyprinus carpio carpio (Linnaeus, 1758) \\
kopvoorn & Squalius cephalus (Linnaeus, 1758) \\
paling & Anguilla anguilla (Linnaeus, 1758) \\
rietvoorn & Scardinius erythrophthalmus (Linnaeus, 1758) \\
riviergrondel & Gobio gobio (Linnaeus, 1758) \\
snoek & Esox lucius (Linnaeus, 1758) \\
tiendoornige stekelbaars & Pungitius pungitius (Linnaeus, 1758) \\
zeelt & Tinca tinca (Linnaeus, 1758) \\
\hline
\end{tabular}


Tabel 16: Vissoorten in de referentielijst van kleine beek (Woluwe en Roodkloosterbeek).

\begin{tabular}{ll}
\hline Referentie soort & \multicolumn{1}{c}{ Wetenschappelijke naam } \\
\hline baars & Perca fluviatilis (Linnaeus, 1758) \\
bittervoorn & Rhodeus sericeus (Pallas, 1776) \\
blankvoorn & Rutilus rutilus (Linnaeus, 1758) \\
driedoornige stekelbaars & Gasterosteus aculeatus (Linnaeus, 1758) \\
Europese meerval & Silurus glanis (Linnaeus, 1758) \\
giebel & Carassius gibelio (Bloch, 1782) \\
rietvoorn & Scardinius erythrophthalmus (Linnaeus, 1758) \\
riviergrondel & Gobio gobio (Linnaeus, 1758) \\
snoek & Esox lucius (Linnaeus, 1758) \\
zeelt & Tinca tinca (Linnaeus, 1758) \\
\hline
\end{tabular}

\subsubsection{Kanalen}

Voor kanalen gebruikten we het werk van Vrielynck et al. (2003). De historische lijst bevat gegevens van kanalen voor de periode 1899-1939. Deze lijst werd aangepast op basis van recente gegevens (1996-2010) (Tabel 17). Verder werden er twee criteria geïntroduceerd om een soort al of niet in de lijst te houden (Ramm, 1990):

1) Vis is lokaal of regionaal uitgestorven;

2) Een kanaal is niet het geprefereerde habitat;

Exotische soorten werden niet in de referentielijst opgenomen uitgezonderd karper, snoekbaars en giebel die we als ingeburgerd beschouwen. De exotische soorten werden bepaald op basis van het werk van Verreycken et al. (2007).

Voor kanalen werden er 23 soorten opgenomen in de referentie lijst.

Enkel deze soorten worden gebruikt voor het bepalen van de metriekwaarden. Naast een beschrijving van het potentieel wordt er ook een maatlat toegepast zodat op basis van een visgemeenschap een oordeel van de status van het oppervlakte water gegeven kan worden. De maatlat of index wordt besproken per waterlichaam. 
Tabel 17: Historische (1899-1939) en recentere (1996-2010) visgegevens van 31 kanalen in Vlaanderen. Gilden: ZW: zoetwater soort; D: diadrome soort; EXO: exotische soort; ES: estuariene soort; MM: marien migrerende soort. De historische abundantie is de relatieve vangstfrequentie in de beschouwde kanalen (gebaseerd op Vrielynck et al., 2003). \# is berekend op het aantal keer een soort gevangen is per methode in de beschouwde kanalen. \#ind. geeft het aantal gevangen individuen weer per soort en per methode in de beschouwde kanalen. De laatste kolom duidt aan of een soort in de MEP of GEP lijst voorkomt.

\begin{tabular}{|c|c|c|c|c|c|c|c|c|c|c|c|}
\hline \multirow[t]{2}{*}{ Wetenschappelijke naam } & \multirow[t]{2}{*}{ Gilde } & \multirow[t]{2}{*}{ Historische abundantie } & \multicolumn{3}{|c|}{ Fuiken (n=258; 874 fuikdagen) } & \multicolumn{3}{|c|}{ Elektrische vangsten (n=351) } & \multicolumn{2}{|c|}{$F \& E$} & \multirow{2}{*}{$\begin{array}{l}\text { MEP } \\
\text { GEP }\end{array}$} \\
\hline & & & \# & frequentie & \# ind. & \# & frequentie & \# ind. & $\#$ & frequentie & \\
\hline Abramis brama (Linnaeus, 1758) & ZW & 7,45 & 18 & 81,82 & 3779 & 19 & 61,29 & 372 & 37 & 69,81 & $\mathrm{x}$ \\
\hline Alburnus alburnus (Linnaeus, 1758) & $\mathrm{ZW}$ & 4,31 & 2 & 9,09 & 44 & 5 & 16,13 & 38 & 7 & 13,21 & $\mathrm{x}$ \\
\hline Alosa alosa (Linnaeus, 1758) & $\mathrm{D}$ & 1,96 & 0 & 0,00 & 0 & 0 & 0,00 & 0 & 0 & 0,00 & \\
\hline Alosa fallax (Lacepède, 1803) & $\mathrm{D}$ & 1,57 & 0 & 0,00 & 0 & 0 & 0,00 & 0 & 0 & 0,00 & \\
\hline Ameiurus nebulosus (Lesueur, 1819) & EXO & 1,18 & 4 & 18,18 & 16 & 1 & 3,23 & 19 & 5 & 9,43 & \\
\hline Anguilla anguilla (Linnaeus, 1758) & $\mathrm{D}$ & 9,02 & 22 & 100,00 & 4283 & 28 & 90,32 & 2853 & 50 & 94,34 & $\mathrm{x}$ \\
\hline Barbatula barbatula (Linnaeus, 1758) & $\mathrm{ZW}$ & 0,00 & 0 & 0,00 & 0 & 3 & 9,68 & 19 & 3 & 5,66 & \\
\hline Barbus barbus (Linnaeus, 1758) & $\mathrm{ZW}$ & 3,14 & 0 & 0,00 & 0 & 0 & 0,00 & 0 & 0 & 0,00 & \\
\hline Blicca bjoerkna (Linnaeus, 1758) & $\mathrm{ZW}$ & 1,57 & 19 & 86,36 & 3838 & 21 & 67,74 & 1305 & 40 & 75,47 & $\mathrm{x}$ \\
\hline Carassius carassius (Linnaeus, 1758) & $\mathrm{ZW}$ & 0,00 & 0 & 0,00 & 0 & 4 & 12,90 & 17 & 4 & 7,55 & $\mathrm{x}$ \\
\hline Carassius gibelio (Bloch, 1782) & EXO & 0,00 & 14 & 63,64 & 800 & 22 & 70,97 & 605 & 36 & 67,92 & $\mathrm{x}$ \\
\hline Chondrostoma nasus (Linnaeus, 1758) & $\mathrm{ZW}$ & 0,39 & 0 & 0,00 & 0 & 0 & 0,00 & 0 & 0 & 0,00 & \\
\hline Cobitis taenia (Linnaeus, 1758) & $\mathrm{ZW}$ & 0,00 & 0 & 0,00 & 0 & 1 & 3,23 & 3 & 1 & 1,89 & \\
\hline Cottus gobio (Linnaeus, 1758) & $\mathrm{ZW}$ & 0,00 & 0 & 0,00 & 0 & 1 & 3,23 & 1 & 1 & 1,89 & \\
\hline Ctenopharyngodon idella (Valenciennes, 1844) & EXO & 0,00 & 1 & 4,55 & 1 & 1 & 3,23 & 1 & 2 & 3,77 & \\
\hline Cyprinus carpio carpio (Linnaeus, 1758) & EXO & 7,45 & 14 & 63,64 & 377 & 16 & 51,61 & 159 & 30 & 56,60 & $\mathrm{x}$ \\
\hline Dicentrarchus labrax (Linnaeus, 1758) & MM & 0,00 & 1 & 4,55 & 1279 & 0 & 0,00 & 0 & 1 & 1,89 & \\
\hline Esox lucius (Linnaeus, 1758) & $\mathrm{ZW}$ & 7,84 & 10 & 45,45 & 19 & 18 & 58,06 & 139 & 28 & 52,83 & $\mathrm{x}$ \\
\hline Gasterosteus aculeatus (Linnaeus, 1758) & $\mathrm{ZW}$ & 1,18 & 7 & 31,82 & 461 & 20 & 64,52 & 575 & 27 & 50,94 & $\mathrm{x}$ \\
\hline Gobio gobio (Linnaeus, 1758) & $\mathrm{ZW}$ & 4,71 & 5 & 22,73 & 51 & 11 & 35,48 & 1677 & 16 & 30,19 & $\mathrm{x}$ \\
\hline Gymnocephalus cernua (Linnaeus, 1758) & $\mathrm{ZW}$ & 3,53 & 21 & 95,45 & 4362 & 19 & 61,29 & 664 & 40 & 75,47 & $\mathrm{x}$ \\
\hline Lampetra fluviatilis (Linnaeus, 1758) & $\mathrm{D}$ & 0,39 & 0 & 0,00 & 0 & 0 & 0,00 & 0 & 0 & 0,00 & \\
\hline Lampetra planeri (Bloch, 1748) & $\mathrm{ZW}$ & 0,39 & 0 & 0,00 & 0 & 0 & 0,00 & 0 & 0 & 0,00 & \\
\hline Lepomis gibbosus (Linnaeus, 1758) & EXO & 0,00 & 11 & 50,00 & 248 & 8 & 25,81 & 955 & 19 & 35,85 & \\
\hline Leucaspius delineatus (Heckel, 1843) & ZW & 0,00 & 2 & 9,09 & 2 & 11 & 35,48 & 179 & 13 & 24,53 & $\mathrm{x}$ \\
\hline Leuciscus idus (Linnaeus, 1758) & $\mathrm{ZW}$ & 0,78 & 8 & 36,36 & 29 & 17 & 54,84 & 103 & 25 & 47,17 & $\mathrm{x}$ \\
\hline Leuciscus leuciscus (Linnaeus, 1758) & $\mathrm{ZW}$ & 0,00 & 0 & 0,00 & 0 & 1 & 3,23 & 3 & 1 & 1,89 & \\
\hline Liza ramada (Risso, 1827) & $\mathrm{D}$ & 0,00 & 1 & 4,55 & 3 & 0 & 0,00 & 0 & 1 & 1,89 & \\
\hline Lota lota (Linnaeus, 1758) & $\mathrm{ZW}$ & 1,18 & 0 & 0,00 & 0 & 0 & 0,00 & 0 & 0 & 0,00 & \\
\hline Oncorhynchus mykiss (Walbaum, 1792) & $\mathrm{ZW}$ & 0,78 & 0 & 0,00 & 0 & 0 & 0,00 & 0 & 0 & 0,00 & \\
\hline Perca fluviatilis (Linnaeus, 1758) & $\mathrm{ZW}$ & 9,02 & 21 & 95,45 & 14926 & 28 & 90,32 & 13954 & 49 & 92,45 & $\mathrm{x}$ \\
\hline Phoxinus phoxinus (Linnaeus, 1758) & $\mathrm{ZW}$ & 0,78 & 0 & 0,00 & 0 & 0 & 0,00 & 0 & 0 & 0,00 & \\
\hline Platichthys flesus (Linnaeus, 1758) & $\mathrm{D}$ & 0,39 & 6 & 27,27 & 156 & 3 & 9,68 & 23 & 9 & 16,98 & $\mathrm{x}$ \\
\hline Pomatoschistus microps (Krøyer, 1838) & ES & 0,00 & 0 & 0,00 & 0 & 1 & 3,23 & 1 & 1 & 1,89 & \\
\hline Pseudorasbora parva (Temminck \& Schlegel, 1846) & EXO & 0,00 & 6 & 27,27 & 68 & 7 & 22,58 & 129 & 13 & 24,53 & \\
\hline Pungitius pungitius (Linnaeus, 1758) & ZW & 1,18 & 1 & 4,55 & 4 & 11 & 35,48 & 217 & 13 & 22,64 & $\mathrm{x}$ \\
\hline Rhodeus sericeus (Pallas, 1776) & $\mathrm{ZW}$ & 0,39 & 3 & 13,64 & 56 & 7 & 22,58 & 246 & 10 & 18,87 & $\mathrm{x}$ \\
\hline Rutilus rutilus (Linnaeus, 1758) & $\mathrm{ZW}$ & 7,84 & 22 & 100,00 & 12172 & 28 & 90,32 & 17778 & 50 & 94,34 & $\mathrm{x}$ \\
\hline Salmo salar (Linnaeus, 1758) & $\mathrm{D}$ & 0,39 & 0 & 0,00 & 0 & 0 & 0,00 & 0 & 0 & 0,00 & \\
\hline Salmo trutta (Linnaeus, 1758) & $\mathrm{D}$ & 0,39 & 0 & 0,00 & 0 & 0 & 0,00 & 0 & 0 & 0,00 & \\
\hline Sander lucioperca (Linnaeus, 1758) & EXO & 2,35 & 19 & 86,36 & 954 & 16 & 51,61 & 102 & 35 & 66,04 & $\mathrm{x}$ \\
\hline Scardinius erythrophthalmus (Linnaeus, 1758) & $\mathrm{ZW}$ & 5,88 & 18 & 81,82 & 1327 & 25 & 80,65 & 1815 & 43 & 81,13 & $\mathrm{x}$ \\
\hline Silurus glanis (Linnaeus, 1758) & $\mathrm{ZW}$ & 0,00 & 0 & 0,00 & 0 & 0 & 0,00 & 0 & 0 & 0,00 & $\mathrm{x}$ \\
\hline Squalius cephalus (Linnaeus, 1758) & $\mathrm{ZW}$ & 2,35 & 0 & 0,00 & 0 & 3 & 9,68 & 24 & 3 & 5,66 & $\mathrm{x}$ \\
\hline Tinca tinca (Linnaeus, 1758) & $\mathrm{ZW}$ & 7,06 & 14 & 63,64 & 155 & 18 & 58,06 & 185 & 32 & 60,38 & $\mathrm{x}$ \\
\hline
\end{tabular}

\section{De toegepaste visindices}

\subsubsection{Rivieren}

\subsubsection{Zenne (grote rivier)}

De lijst van metrieken (Tabel 18) blijft onveranderd zoals voorgesteld in Triest et al. (2004). 
Tabel 18: Metrieken en grenswaarden voor de Zenne (grote rivier). Legende afkortingen: O: Ontoereikend = verstoorde situatie; GEP: Goed Ecologisch Potentieel; MEP: Maximaal Ecologisch Potentieel; R: Referentie.

\begin{tabular}{|c|c|c|c|c|}
\hline \multirow[t]{2}{*}{ Metriek } & \multicolumn{4}{|c|}{ Grenswaarden } \\
\hline & $\mathrm{O}$ & GEP & MEP & $\mathrm{R}$ \\
\hline \multicolumn{5}{|l|}{ Samenstelling en abundantie } \\
\hline Aantal soorten & $<8$ & $8-10$ & $11-13$ & $>13$ \\
\hline \multicolumn{5}{|l|}{ Trofische compositie } \\
\hline piscivore individuen (\%) & $<3 \&>7$ & $3-4$ & $>5-7$ & $>4-5$ \\
\hline omnivore individuen (\%) & $>5$ & $5->2$ & $2-1$ & $<1$ \\
\hline invertivore individuen (\%) & $>60 \&<35$ & $35-40$ & $>40-45$ & $>45-60$ \\
\hline Shannon-Weaner index & $<0,53$ & $0,53-0.60$ & $>0,60-0,68$ & $>0.68$ \\
\hline Migratiewaarde & $<2$ & $2-4$ & $>4-6$ & $>6$ \\
\hline \multicolumn{5}{|l|}{ Typespecifieke soorten } \\
\hline Referentie soorten & & paling; riviergrondel & paling; riviergrondel; blankvoorn & paling; riviergrondel; blankvoorn; beekforel \\
\hline Gemiddelde tolerantiewaarde & $<1,6$ & $1.6-<2$ & $2-<2,4$ & $\geq 2,4$ \\
\hline \multicolumn{5}{|l|}{ Leeftijdsopbouw } \\
\hline Lengteklasse waarde & $<2$ & $2-2,49$ & $2,5-3,99$ & $\geq 4$ \\
\hline
\end{tabular}

Wanneer er twee of minder soorten worden gevangen is de beoordeling "slecht".

\subsubsection{Woluwe en Roodkloosterbeek (kleine beek)}

De lijst van metrieken (Tabel 19) blijft onveranderd zoals voorgesteld in Triest et al. (2004).

Tabel 19: Metrieken en grenswaarden voor de Woluwe en roodkloosterbeek (kleine beek). Legende afkortingen: O: Ontoereikend = verstoorde situatie; GEP: Goed Ecologisch Potentieel; MEP: Maximaal Ecologisch Potentieel; R: Referentie.

\begin{tabular}{|c|c|c|c|c|}
\hline \multirow[t]{2}{*}{ Metriek } & \multicolumn{4}{|c|}{ Grenswaarden } \\
\hline & $\mathrm{O}$ & GEP & MEP & $\mathrm{R}$ \\
\hline \multicolumn{5}{|l|}{ Samenstelling en abundantie } \\
\hline Aantal soorten & $<5$ & $5-<8$ & $8-9$ & $>9$ \\
\hline \multicolumn{5}{|l|}{ Trofische compositie } \\
\hline piscivore individuen (\%) & $<3 \&>7$ & 3-4 & $>5-7$ & $>4-5$ \\
\hline omnivore individuen (\%) & $>5$ & $5->2$ & 2-1 & $<1$ \\
\hline invertivore individuen (\%) & $>60 \&<35$ & $35-40$ & $>40-45$ & $>45-60$ \\
\hline Shannon-Weaner index & $<0,53$ & $0,53-0,60$ & $>0,60-0,68$ & $>0,68$ \\
\hline Migratiewaarde & $<2$ & $2-4$ & $>4-6$ & $>6$ \\
\hline \multicolumn{5}{|l|}{ Typespecifieke soorten } \\
\hline Referentie soorten & & blankvoorn; rietvoorn & blankvoorn; rietvoorn; bermpje & blankvoorn; rietvoorn; bermpje; kopvoorn \\
\hline Gemiddelde tolerantiewaarde & $<1,6$ & $1,6-<2$ & $2-<2,4$ & $\geq 2,4$ \\
\hline \multicolumn{5}{|l|}{ Leeftijdsopbouw } \\
\hline Lengteklasse waarde & $<2$ & $2-2,49$ & 2,5-3,99 & $\geq 4$ \\
\hline
\end{tabular}

Wanneer er twee of minder soorten worden gevangen is de beoordeling "slecht".

De som van de verschillende scores geeft de index (IBIB) deze wordt omgerekend zoals hierboven beschreven tot een EQR. De grenswaarden van de EQR en de beoordeling staan in Tabel 20. 
Tabel 20: Overzicht van de EQR grenswaarden en de beoordeling.

\begin{tabular}{cc}
\hline EQR & Beoordeling \\
\hline 1 & MEP \\
$>0,75 \&<1$ & GEP \\
$>0,5 \& \leq 0,75$ & Matig \\
$>0,25 \& \leq 0,5$ & Ontoereikend \\
$\leq 0,25$ & Slecht \\
\hline
\end{tabular}

\subsubsection{Het kanaal Brussel-Charleroi}

De lijst van metrieken (Tabel 21) blijft onveranderd zoals voorgesteld in Van Onsem et al. (2014).

Tabel 21: Overzicht van de grenswaarden van de geselecteerde metrieken, EQR en de beoordeling.

\begin{tabular}{|c|c|c|c|c|c|}
\hline \multicolumn{6}{|c|}{ Kanalen elektrische visserij } \\
\hline & MEP & GEP & Matig & Ontoereikend & Slecht \\
\hline Metriek/score & 1 & 0,8 & 0,6 & 0,4 & 0,2 \\
\hline MnsTot (\#) & $\geq 18$ & $<18 \geq 7$ & $<7 \geq 5$ & $<5 \geq 2$ & $<2$ \\
\hline ManBio $\left(\mathrm{g} / \mathrm{m}^{2}\right)$ & & $\geq 32,6$ & $<32,6 \geq 24,5$ & $<24,5 \geq 16,3$ & $<16,3$ \\
\hline ManSha $(\mathrm{H})$ & & $\geq 1,64$ & $<1,64 \geq 1,23$ & $<1,23 \geq 0,82$ & $<0,82$ \\
\hline \multicolumn{6}{|c|}{ Kanalen fuikvisserij } \\
\hline Metriek/score & 1 & 0,8 & 0,6 & 0,4 & 0,2 \\
\hline ManRek (\%) & 100 & $<100 \geq 80$ & $<80 \geq 53,3$ & $<53,3 \geq 26,7$ & $<26,7$ \\
\hline BenWei (\% gewicht) & & $<22,2$ & $<44,4 \geq 22,2$ & $<66,6 \geq 44,4$ & $<11,1 \geq 66,6$ \\
\hline EQR & 1 & $<1 \geq 0,75$ & $<0,75 \geq 0,50$ & $<0,50 \geq 0,25$ & $<0,25$ \\
\hline Beoordeling & MEP & GEP & Matig & Ontoereikend & Slecht \\
\hline
\end{tabular}

Voor het berekenen van de ecologische toestand berekenen we specifieke metrieken voor de elektrische vangsten en fuikvangsten apart. Daarbij houden we enkel rekening met vissen die in de referentie lijst (Tabel 5) voorkomen. De scores worden wel samen verrekend naar één indexwaarde. Voor de elektrische vangsten werden drie metrieken bepaald: totaal aantal soorten (MnsTot), totale biomassa in $\mathrm{g} / \mathrm{m}^{2}$ (ManBio) en de Shannon Wiener index (ManSha) die een maat is voor de evenness of diversiteit van soorten. Met de fuikvangsten berekenen we twee metrieken: percentage van aantal soorten die rekruteren (ManRek), gebaseerd op voorkomen van verschillende lengte klassen per soort, en het gewichtspercentage benthivore soorten (BenWei; brasem, kolblei, karper, pos en zeelt). De som van de verschillende metriekscores bepaalt de indexwaarde. Deze waarde wordt dan omgerekend naar de EQR zoals hierboven beschreven. 


\subsubsection{Besluit}

We gebruiken dezelfde maatlatten voor de rivieren zoals beschreven in Triest et al. (2008). Voor de kanalen in het Brussels Gewest is een nieuwe maatlat ontwikkeld die ook in Vlaanderen wordt toegepast. De ontwikkelde maatlatten of IBIB geven de status van het onderzochte oppervlaktewater weer. De ontwikkelde maatlatten zijn in overeenstemming met de Kaderrichtlijn Water en beschrijven het goede en maximaal ecologisch potentieel en waar relevant de referentie. Voor het gebruik van deze maatlat en het bepalen van de status dient men de beschreven methode toe te passen. De uiteindelijke beoordeling voor de Woluwe en de Roodkloosterbeek moet nog steeds met de nodige voorzichtigheid worden benaderd gezien extra analyses de voorgestelde maatlatten nog kunnen verfijnen.

\section{Verwerking van de gegevens}

Om de data statistisch te vergelijken (temporeel) werden alle najaar gegevens voor de periode 2004 tot en met 2016 omgerekend naar relatieve abundantie (\% van de totale vangst per locatie, per jaar). Voor de gegevens van 2016 vergelijken we de vangsten van het voorjaar met die van het najaar.

We gebruikten R als statistisch software (versie R.3.02).

\subsection{Resultaten}

In opdracht van het BIM werden op verschillende locaties in het Brussels Gewest visbestandopnames uitgevoerd (Tabel 22). De gebruikte technieken stemmen volledig overeen met deze tijdens de campagne in 2004, 2007 en 2013. Ditmaal werden de locaties twee maal bemonsterd $\mathrm{nl}$. in het voorjaar en in het najaar. De Zenne werd ook in de zomer bemonsterd omdat er problemen waren met de afvissing in het voorjaar. Naast biotische data noteerden we ook enkele abiotische gegevens en een biotoopbeschrijving. De abiotische gegevens zijn: zuurstof, zuurgraad of $\mathrm{pH}$, conductiviteit, watertemperatuur, turbiditeit, saliniteit en doorzicht.

Tabel 22: Coördinaten van de bemonsteringspunten.

\begin{tabular}{|c|c|c|c|c|}
\hline Bemonsteringspunt & Code & Plaats & $\mathbf{x}$ & $\mathbf{Y}$ \\
\hline Zenne & S4 & Haren, Budabrug & 153632 & 178620 \\
\hline Zenne & S2 & Anderlecht/ Viangros & 145520 & 167784 \\
\hline Brussel Charleroi & $\mathrm{C} 2$ & Haren, Budabrug & 159751 & 177153 \\
\hline Brussel Charleroi & $\mathrm{C} 1$ & Anderlecht, Ring West & 145198 & 167443 \\
\hline Woluwe & W2 & Hof ter Musschen & 155425 & 171663 \\
\hline Roodkloosterbeek & RK & Bergojepark & 154266 & 167076 \\
\hline
\end{tabular}




\subsubsection{Zenne}

\subsubsection{Inleiding}

Het stuk gelegen in het Brusselse Hoofdstedelijke Gewest behoort niet tot het getijdewater. Jochems et al. (2002) hebben in de Vlaamse bekkens acht riviertypes bepaald op basis van de hoogteligging, hydro-ecoregio en de bekkenoppervlakte (4 klassen). Volgens deze criteria behoort de Zenne, met een bekkenoppervlakte van $1160 \mathrm{~km}^{2}$, tot het type 'grote rivier'. De Zenne werd in het voorjaar, in de zomer en in het najaar op twee plaatsen bemonsterd door middel van elektrische visserij. De plaats in Anderlecht (S2) heeft overal kunstmatige en steile oevers en het elektrisch vissen wordt bemoeilijkt door de sterke stroming. De tweede plaats (S4) is stroomafwaarts het viaduct van Vilvoorde nabij de Initial Hospital Services. Op deze plaats ligt er zeer veel rotzooi op de bodem (ijzer, stenen enz...). In beide locaties werd met twee elektroden gevist over een afstand van $100 \mathrm{~m}$ langs beide oevers. In de locatie S4 werden er in de zomer ook twee fuiken geplaatst. Deze fuikgegevens worden niet gebruikt voor het bereken van de IBIB, maar geven wel extra informatie over de biodiversiteit.

\subsubsection{Abiotische data op het moment van de staalnames}

Op locatie S2 werd er niet gevist in het voorjaar en werden dus ook geen omgevingsvariabelen gemeten. In de zomer had het voor de staalname heel veel geregend. Het water zag er smerig uit en stond heel hoog. Dat verklaart ook de hoge turbiditeit (Tabel 23).

Tabel 23: Overzicht van de omgevingsvariabelen gemeten op het moment van de staalnames in de Zenne.

\begin{tabular}{|c|c|c|c|c|c|c|c|c|}
\hline Code & Datum & Watertemperatuur $\left({ }^{\circ} \mathrm{C}\right)$ & $\mathrm{O}_{2} \quad(\mathrm{mg} / \mathrm{l})$ & $\mathrm{O}_{2}(\%)$ & $\mathrm{pH}$ & Turbiditeit (NTU) & Saliniteit (\%) & Conductiviteit $(\mu \mathrm{S} / \mathrm{cm})$ \\
\hline S4 & $12 / 05 / 2016$ & 18,7 & 5,35 & 58,8 & 7 & 9,79 & & 1050 \\
\hline S2 & $13 / 06 / 2016$ & 17 & 6,41 & 68,2 & 7,01 & 110 & & 639 \\
\hline S4 & $13 / 06 / 2016$ & 19 & 5,96 & 66 & 6,98 & 48,2 & & 667 \\
\hline S4 & $14 / 06 / 2016$ & 16,8 & 6,33 & 67 & 7,18 & 44,2 & & 735 \\
\hline S4 & $25 / 10 / 2016$ & 13,8 & 6,76 & 64,5 & 7,78 & 16 & 0,54 & 847 \\
\hline S2 & $25 / 10 / 2016$ & 11,1 & 7,73 & 69,5 & 7,65 & 11,7 & 0,49 & 724 \\
\hline
\end{tabular}

In 2013 werd in locatie S4 een te lage zuurstofconcentratie gemeten. In 2016 was de zuurstofconcentratie op het moment van de staalnames telkens boven de norm van $6 \mathrm{mg} / \mathrm{l}$ (Belgisch Staatsblad 2016).

\subsubsection{Resultaten vismonitoring}

Zoals hierboven al vermeld werd er in de Zenne gevist in het voorjaar, de zomer en het najaar. In de zomer werden twee dubbele schietfuiken geplaatst op locatie S4 (Tabel 24). 
Tabel 24: Specificaties van de gebruikte technieken voor het afvissen in de Zenne in 2016.

\begin{tabular}{|c|c|c|c|c|c|c|}
\hline Waterloop & Code & Afvissingstechniek & Lengte transect (m) & Breedte transect $(\mathrm{m})$ & Oppervlakte van transect $\left(\mathrm{m}^{2}\right)$ & Fuikdagen \\
\hline Zenne & S2 & $12 / 05 / 2016$ niet gevist & & & & \\
\hline Zenne & S4 & 12/05/2016 elektrisch & 100 & 2,5 & 250 & \\
\hline Zenne & S2 & 13/06/2016 elektrisch & 200 & 2,5 & 500 & \\
\hline Zenne & S4 & 13/06/2016 elektrisch & 200 & 2 & 400 & \\
\hline Zenne & S4 & 14/06/2016 fuik & & & & 2 \\
\hline Zenne & S4 & 25/10/2016 elektrisch & 200 & 2,5 & 500 & \\
\hline Zenne & S2 & 25/10/2016 elektrisch & 200 & 2,5 & 500 & \\
\hline
\end{tabular}

Alle gevangen vissen werden tot op soort gedetermineerd, gemeten (totale lengte tot $0.1 \mathrm{~cm}$ nauwkeurig) en gewogen (nat gewicht tot $0.1 \mathrm{~g}$ nauwkeurig). Nadien werden alle vissen teruggeplaatst.

In 2016 stelden we een toename vast van het visleven in de Zenne (Tabel 25). Tijdens de vorige campagnes werd er geen tot weinig vis gevangen. In 2004 werd er niet gevist in de Zenne gezien er geen visleven mogelijk was. In 2007 bemonsterden we twee locaties maar we vingen geen vissen. In 2013 werd op de locatie S2 weerom geen vis gevangen. Echter werd er wel één giebel met een gewicht van $46.2 \mathrm{~g}$ gevangen in S4.

Tabel 25: Overzicht van aantal individuen gevangen per soort en methode (E: elektrisch; F: fuik) tijdens de verschillende campagnes in de Zenne.

\begin{tabular}{lccccccc}
\hline Locatie & $\mathrm{S} 2$ & $\mathrm{~S} 2$ & $\mathrm{~S} 2$ & $\mathrm{~S} 4$ & $\mathrm{~S} 4$ & $\mathrm{~S} 4$ & $\mathrm{~S} 4$ \\
Datum & $1 / 07 / 2013$ & $13 / 06 / 2016$ & $25 / 10 / 2016$ & $1 / 07 / 2013$ & $13 / 06 / 2016$ & $14 / 06 / 2016$ & $25 / 10 / 2016$ \\
Methode & $\mathrm{E}$ & $\mathrm{E}$ & $\mathrm{E}$ & $\mathrm{E}$ & $\mathrm{E}$ & $\mathrm{F}$ & $\mathrm{E}$ \\
\hline baars & 0 & 6 & 2 & 0 & 3 & 0 & 0 \\
bermpje & 0 & 14 & 23 & 0 & 0 & 0 & 0 \\
bittervoorn & 0 & 0 & 0 & 0 & 0 & 0 & 2 \\
blankvoorn & 0 & 0 & 0 & 0 & 0 & 2 & 0 \\
blauwbandgrondel & 0 & 2 & 2 & 0 & 6 & 3 & 0 \\
driedoornige stekelbaars & 0 & 45 & 62 & 0 & 1 & 4 & 6 \\
giebel & 0 & 11 & 1 & 1 & 7 & 34 & 3 \\
karper & 0 & 0 & 0 & 0 & 0 & 17 & 0 \\
kolblei & 0 & 0 & 0 & 0 & 0 & 3 & 0 \\
kopvoorn & 0 & 1 & 0 & 0 & 0 & 0 & 0 \\
paling & 0 & 0 & 0 & 0 & 0 & 4 & 0 \\
rietvoorn & 0 & 0 & 0 & 0 & 0 & 5 & 0 \\
riviergrondel & 0 & 0 & 6 & 0 & 0 & 1 & 0 \\
tiendoornige stekelbaars & 0 & 4 & 0 & 0 & 1 & 0 & 0 \\
zonnebaars & 0 & 0 & 0 & 0 & 0 & 1 & 0 \\
\hline Totaal aantal soorten & 0 & 7 & 6 & 1 & 5 & 10 & 3 \\
Totaal aantal individuen & 0 & 83 & 96 & 1 & 18 & 74 & 11 \\
\hline
\end{tabular}

Op locatie S2 werd in 2016 een verbetering vastgesteld wat betreft de visgemeenschap. In de zomercampagne vingen we 7 soorten en 6 in het najaar van 2016. Vooral de aanwezigheid van bermpje en een kopvoorn is een teken dat de waterkwaliteit op deze locatie is toegenomen. Baars gevangen in de zomer waren juveniele dieren met een gemiddelde lengte van $3,5 \mathrm{~cm}$ en een gemiddeld gewicht 
van $0,4 \mathrm{~g}$. In het najaar vingen we grotere baarzen: gemiddeld $13,5 \mathrm{~cm}$ met een gemiddeld gewicht van $34,2 \mathrm{~g}$. Ook de bermpjes waren gemiddeld kleiner in de zomer $(2,7 \mathrm{~cm}$ en $1,2 \mathrm{~g})$ dan in het najaar $(9,2 \mathrm{~cm}$ en 5,9 g). Riviergrondel werd in S2 enkel in het najaar gevangen met een gemiddelde lengte van $3,6 \mathrm{~cm}$ en $0,4 \mathrm{~g}$ gemiddeld gewicht. Het gaat hier dus duidelijk om juveniele dieren.

Op locatie S4 merken we ook een toename van het aantal vissen op. Met fuiken vingen we meer soorten dan met het elektrisch toestel. Naast de exoten blauwbandgrondel, giebel en zonnebaars vingen we er ook rietvoorn, baars en blankvoorn. Giebels gevangen met elektriciteit waren in de zomer gemiddeld 5,3 cm lang met een gemiddeld gewicht van 10,6 g. Met de fuiken vingen we grotere giebels: gemiddeld $20,5 \mathrm{~cm}$ en $313,7 \mathrm{~g}$. In het najaar vingen we met elektriciteit minder giebels $(7,7 \mathrm{~cm}$ en $9,7 \mathrm{~g}$ gemiddeld). De lengte van de paling gevangen in het voorjaar varieerde van $29,6 \mathrm{~cm}$ tot $98 \mathrm{~cm}$. Er werden zowel kleine $(11,1 \mathrm{~cm})$ als grote $(63,8 \mathrm{~cm})$ karpers gevangen in het voorjaar. De gevangen blankvoorns en rietvoorns waren juvenielen met een gemiddelde lengte van 8,4 en $9,2 \mathrm{~cm}$ respectievelijk.

Tabel 26: Overzicht van totaal gewicht (in g) gevangen per soort en methode (E: elektrisch; F: fuik) tijdens de verschillende campagnes in de Zenne.

\begin{tabular}{lccccccc}
\hline Locatie & $\mathrm{S} 2$ & $\mathrm{~S} 4$ & $\mathrm{~S} 2$ & $\mathrm{~S} 4$ & $\mathrm{~S} 4$ & $\mathrm{~S} 4$ & $\mathrm{~S} 2$ \\
Datum & $1 / 07 / 2013$ & $1 / 07 / 2013$ & $13 / 06 / 2016$ & $13 / 06 / 2016$ & $14 / 06 / 2016$ & $25 / 10 / 2016$ & $25 / 10 / 2016$ \\
Methode & $\mathrm{E}$ & $\mathrm{E}$ & $\mathrm{E}$ & $\mathrm{E}$ & $\mathrm{F}$ & $\mathrm{E}$ & $\mathrm{E}$ \\
\hline baars & 0 & 0 & 2,5 & 1,9 & 0 & 0 & 68,4 \\
bermpje & 0 & 0 & 8,9 & 0 & 0 & 0 & 135,3 \\
bittervoorn & 0 & 0 & 0 & 0 & 0 & 2,8 & 0 \\
blankvoorn & 0 & 0 & 0 & 0 & 11,7 & 0 & 0 \\
blauwbandgrondel & 0 & 0 & 4,7 & 7 & 9,8 & 0 & 0,2 \\
driedoornige stekelbaars & 0 & 0 & 13,5 & 0,2 & 12,8 & 10,4 & 86,1 \\
giebel & 0 & 46,2 & 96,2 & 74,4 & 10665,5 & 29,1 & 0,1 \\
karper & 0 & 0 & 0 & 0 & 30462,8 & 0 & 0 \\
kolblei & 0 & 0 & 0 & 0 & 211,7 & 0 & 0 \\
kopvoorn & 0 & 0 & 44,4 & 0 & 0 & 0 & 0 \\
paling & 0 & 0 & 0 & 0 & 3647,8 & 0 & 0 \\
rietvoorn & 0 & 0 & 0 & 0 & 40,4 & 0 & 0 \\
riviergrondel & 0 & 0 & 0 & 0 & 9,6 & 0 & 2,6 \\
tiendoornige stekelbaars & 0 & 0 & 0,7 & 0,1 & 0 & 0 & 0 \\
zonnebaars & 0 & 0 & 0 & 0 & 9 & 0 & 0 \\
\hline totaal gewicht & 0 & 46,2 & 170,9 & 83,6 & 45081,1 & 42,3 & 292,7 \\
\hline
\end{tabular}

We kunnen dus stellen dat de situatie op beide locaties verbeterd is maar toch blijven beide locaties nog steeds sterk beïnvloed door menselijke invloed. Kanalisatie en sterke stromingen maken het niet gemakkelijk voor de vissen om er zich te handhaven. De bodem is bezaaid met afval. 


\subsubsection{Woluwe en Roodkloosterbeek}

\subsubsection{Inleiding}

Beide rivieren behoren tot het type "kleine beek". Een kleine beek heeft een bekkenoppervlakte $<100 \mathrm{~km}^{2}$ en ligt in de hydro-ecoregio zand-zandleem-leem. De Roodkloosterbeek ontspringt in het Zoniënwoud, in Tervuren, waar hij onder andere het water van de Keizersbron opvangt. Hij voedt de vijvers van het Rood Klooster, stroomt door het Bergojepark, dat vroeger deel uitmaakte van het Zoniënwoud, en mondt uit in de Woluwe. De Woluwe ontspringt in Watermaal-Bosvoorde in het zuidoosten van het Brussels Hoofdstedelijk Gewest, ter hoogte van de Kattenberg. De Woluwe stroomt door het Brussels Hoofdstedelijk Gewest doorheen Oudergem, Sint-Pieters-Woluwe en Sint-Lambrechts-Woluwe. Daarna stroomt ze verder door Vlaams-Brabant en mondt uit in de Zenne in Vilvoorde. De totale lengte van de Woluwe is $10,5 \mathrm{~km}$. Beide waterlopen zijn sterk veranderd door kanalisatie en overwelving. Toch bevat de Woluwe nog mooie, quasi ongerepte, stukken. De Woluwe nabij Hof ter Musschen en de Roodkloosterbeek in het Bergojepark werden wadend bemonsterd in het voorjaar en in het najaar.

\subsubsection{Abiotische data op het moment van de staalnames}

Op het moment van de staalnames werden geen aberraties genoteerd wat betreft de waterkwaliteit. De pH waarde van 6,66, voor de Woluwe op 7/10/2016, is waarschijnlijk fout ten gevolge van een technisch defect.

Tabel 27: Overzicht van de omgevingsvariabelen gemeten op het moment van de staalnames in de Roodkloosterbeek en Woluwe.

\begin{tabular}{|c|c|c|c|c|c|c|c|c|c|}
\hline Waterloop & Code & Datum & Watertemperatuur $\left({ }^{\circ} \mathrm{C}\right)$ & $\mathrm{O}_{2} \quad(\mathrm{mg} / \mathrm{l})$ & $\mathrm{O}_{2}(\%)$ & $\mathrm{pH}$ & Turbiditeit (NTU) & Saliniteit (\%) & Conductiviteit $(\mu \mathrm{S} / \mathrm{cm})$ \\
\hline Roodkloosterbeek & RK & 9/05/2016 & 19,3 & 6,97 & 77,1 & 7,7 & 5,77 & & 652 \\
\hline Roodkloosterbeek & RK & $7 / 10 / 2016$ & 12,2 & 10,64 & 98,7 & 8,12 & 1,13 & 0,31 & 479 \\
\hline Woluwe & W2 & $9 / 05 / 2016$ & 19,5 & 7,83 & 87,9 & 8 & 9,44 & & 623 \\
\hline Woluwe & W2 & $7 / 10 / 2016$ & 12,5 & 9,59 & 89,3 & 6,66 & 5,73 & 0,34 & 525 \\
\hline
\end{tabular}

\subsubsection{Resultaten vismonitoring}

In beide rivieren werd er in het voorjaar en het najaar van 2016 elektrisch wadend gevist met twee anoden over een afstand van $100 \mathrm{~m}$ waarbij de totale breedte werd bestreken (Tabel 28).

Tabel 28: Specificaties van de gebruikte technieken voor het afvissen in de Woluwe en Roodkloosterbeek in 2016.

\begin{tabular}{|c|c|c|c|c|c|c|}
\hline Waterloop & Code & Datum & Afvissingstechniek & Lengte transect $(\mathrm{m})$ & Breedte transect $(\mathrm{m})$ & Oppervlakte van transect $\left(\mathrm{m}^{2}\right)$ \\
\hline Roodkloosterbeek & RK & $9 / 05 / 2016$ & elektrisch & 100 & 3,1 & 310 \\
\hline Roodkloosterbeek & RK & $7 / 10 / 2016$ & elektrisch & 100 & 2,7 & 270 \\
\hline Woluwe & W2 & $9 / 05 / 2016$ & elektrisch & 100 & 3 & 300 \\
\hline Woluwe & W2 & $7 / 10 / 2016$ & elektrisch & 200 & 3 & 600 \\
\hline
\end{tabular}




\subsection{Woluwe}

In 2016 vingen we in totaal 10 vissoorten: 7 in het voorjaar en 8 in het najaar. In de zomer van 2013 werden er in totaal 7 soorten gevangen, 10 in het najaar van 2007 en 9 in de zomer van 2004 (Tabel 29). Pos gevangen in 2013 werd niet meer terug gevangen, dat geldt ook voor giebel die wel gevangen werd in vorige campagnes en zeelt gevangen in 2004 en 2008. Bittervoorn en riviergrondel werden in 2016 opnieuw goed gevangen in de Woluwe. Beide soorten hebben voldoende zuurstof ( $>5 \mathrm{mg} / \mathrm{l})$ nodig om te aarden in een bepaald habitat. Paling $(80 \mathrm{~cm} ; 938,6 \mathrm{~g})$ werd voor het eerst gevangen in 2016.

Tabel 29: Overzicht van aantal individuen gevangen per soort tijdens de verschillende campagnes in de Woluwe.

\begin{tabular}{lccccc}
\hline Datum & $10 / 06 / 2004$ & $2 / 10 / 2007$ & $3 / 06 / 2013$ & $9 / 05 / 2016$ & $7 / 10 / 2016$ \\
\hline baars & 5 & 23 & 7 & 3 & 1 \\
bittervoorn & 15 & 356 & 182 & 240 & 1363 \\
blankvoorn & 33 & 45 & 1 & 1 & 18 \\
brasem & 0 & 5 & 0 & 10 & 0 \\
driedoornige stekelbaars & 33 & 28 & 42 & 32 & 168 \\
giebel & 3 & 14 & 1 & 0 & 0 \\
karper & 0 & 1 & 0 & 1 & 0 \\
paling & 0 & 0 & 0 & 0 & 1 \\
pos & 0 & 0 & 1 & 0 & 0 \\
rietvoorn & 1 & 6 & 0 & 0 & 2 \\
riviergrondel & 33 & 91 & 186 & 78 & 102 \\
snoek & 2 & 0 & 0 & 0 & 2 \\
zeelt & 2 & 1 & 0 & 0 & 0 \\
\hline Totaal aantal soorten & 9 & 10 & 7 & 7 & 8 \\
Totaal aantal individuen & 127 & 570 & 420 & 365 & 1657 \\
\hline
\end{tabular}

De gemiddelde lengte van de baarzen gevangen in het voorjaar was $34,6 \mathrm{~cm}$ met een gemiddeld gewicht van $626,8 \mathrm{~cm}$. Dat zijn dus duidelijk volwassen exemplaren. In het najaar werd slechts een volwassen baars van $33,8 \mathrm{~cm}$ lang gevangen. In het voorjaar van 2016 vingen we ook volwassen brasem (gem. 37,7 cm met gem. gewicht 664,9 g). In het voorjaar van 2016 vingen we een juveniele blankvoorn $(5,2 \mathrm{~cm})$ terwijl in het najaar grotere exemplaren werden gevangen (gem. $12,3 \mathrm{~cm}$ met een gem. gewicht van 21,3 g). De gemiddelde lengte van riviergrondels in het voorjaar van 2016 was $8,2 \mathrm{~cm}$ (7,2 g gemiddeld) terwijl in het najaar de gemiddelde lengte 10,2 $\mathrm{cm}$ was met een gemiddeld gewicht van $12,5 \mathrm{~g}$. 
Tabel 30: Overzicht van totaal gewicht (in g) gevangen per soort tijdens de verschillende campagnes in de Woluwe.

\begin{tabular}{lccccc}
\hline Datum & $10 / 06 / 2004$ & $2 / 10 / 2007$ & $3 / 06 / 2013$ & $9 / 05 / 2016$ & $7 / 10 / 2016$ \\
\hline baars & 685,6 & 953,3 & 806,2 & 1880,4 & 569,8 \\
bittervoorn & 29,1 & 410,6 & 293,7 & 323,6 & 1546,2 \\
blankvoorn & 2912,8 & 2745,6 & 2,5 & 1,2 & 384 \\
brasem & 0 & 42 & 0 & 6648,8 & 0 \\
driedoornige stekelbaars & 15,9 & 6,8 & 44 & 44 & 92,4 \\
giebel & 190,3 & 1708,2 & 1420,7 & 0 & 0 \\
karper & 0 & 142,2 & 0 & 1616 & 0 \\
paling & 0 & 0 & 0 & 0 & 938,6 \\
pos & 0 & 0 & 34,5 & 0 & 0 \\
rietvoorn & 96,2 & 266,2 & 0 & 0 & 2,1 \\
riviergrondel & 530,4 & 800,3 & 1687,1 & 563,3 & 1273,6 \\
snoek & 321,8 & 0 & 0 & 0 & 3007 \\
zeelt & 123,1 & 76,2 & 0 & 0 & 0 \\
\hline totaal gewicht & 4905,2 & 7151,4 & 4288,7 & 11077,3 & 7814 \\
\hline
\end{tabular}

De totale biomassa per soort verschilt met de jaren (Tabel 30). In 2016 was het aandeel bittervoorn het grootst. In 2013 droeg riviergrondel het meeste bij tot de biomassa terwijl in vorige campagnes blankvoorn de hoogste bijdrage had.

De visgemeenschap in de Woluwe is redelijk stabiel.

\subsection{Roodkloosterbeek}

In de Roodkloosterbeek vingen we in 20167 soorten: 4 in het voorjaar en 6 in het najaar (Tabel 31). Vergeleken met vorige campagnes is dat een toename van het aantal gevangen soorten. We vingen duidelijk meer riviergrondel dan in vorige campagnes. De aanwezigheid van zeelt en bittervoorn is positief.

Tabel 31: Overzicht van aantal individuen gevangen per soort tijdens de verschillende campagnes in de Roodkloosterbeek.

\begin{tabular}{lccccc}
\hline Datum & $10 / 06 / 2004$ & $2 / 10 / 2007$ & $3 / 06 / 2013$ & $9 / 05 / 2016$ & $7 / 10 / 2016$ \\
\hline bittervoorn & 0 & 0 & 0 & 0 & 1 \\
brasem & 0 & 1 & 0 & 0 & 0 \\
bruine Amerikaanse dwergmeerval & 0 & 0 & 0 & 2 & 0 \\
driedoornige stekelbaars & 0 & 0 & 0 & 0 & 2 \\
Europese meerval & 3 & 0 & 0 & 0 & 1 \\
giebel & 2 & 0 & 0 & 0 & 0 \\
pos & 0 & 0 & 0 & 0 & 2 \\
rietvoorn & 0 & 0 & 0 & 6 & 1 \\
riviergrondel & 6 & 50 & 55 & 158 & 269 \\
zeelt & 0 & 0 & 0 & 1 & 0 \\
\hline Totaal aantal soorten & 3 & 2 & 1 & 4 & 6 \\
Totaal aantal individuen & 11 & 51 & 55 & 167 & 276 \\
\hline
\end{tabular}


De gevangen rietvoorn in het voorjaar van 2016 waren kleine juveniele exemplaren met een gemiddelde lengte van $4,9 \mathrm{~cm}$ en een gemiddeld gewicht van 1,3 g. In het najaar werd een groter juveniel exemplaar van $7,4 \mathrm{~cm}$ gevangen. De gemiddelde lengte van riviergrondel gevangen in het voorjaar $(5,2 \mathrm{~cm})$ en in het najaar $(6,5 \mathrm{~cm})$ verschilt weinig.

Tabel 32: Overzicht van totaal gewicht (in g) gevangen per soort tijdens de verschillende campagnes in de Roodkloosterbeek.

\begin{tabular}{lccccc}
\hline Datum & $10 / 06 / 2004$ & $2 / 10 / 2007$ & $3 / 06 / 2013$ & $9 / 05 / 2016$ & $7 / 10 / 2016$ \\
\hline bittervoorn & 0 & 0 & 0 & 0 & 0,1 \\
brasem & 0 & 3,6 & 0 & 0 & 0 \\
bruine Amerikaanse dwergmeerval & 0 & 0 & 0 & 146,2 & 0 \\
driedoornige stekelbaars & 0 & 0 & 0 & 0 & 0,8 \\
Europese meerval & 33,2 & 0 & 0 & 0 & 18,5 \\
giebel & 4 & 0 & 0 & 0 & 0 \\
pos & 0 & 0 & 0 & 0 & 9,1 \\
rietvoorn & 0 & 0 & 0 & 7,6 & 4 \\
riviergrondel & 40,6 & 111,8 & 170 & 228,3 & 587,1 \\
zeelt & 0 & 0 & 0 & 0,9 & 0 \\
\hline totaal gewicht & 77,8 & 115,4 & 170 & 383 & 619,6 \\
\hline
\end{tabular}

De Roodkloosterbeek heeft nog steeds een fragiel visbestand. De dominantie van riviergrondel is niet positief.

\subsubsection{Het kanaal Brussel-Charleroi}

\subsubsection{Inleiding}

Het Kanaal Charleroi-Brussel-Schelde wordt ten zuiden van Brussel "Kanaal naar Charleroi" genoemd en ten noorden van Brussel het "Kanaal Brussel-Schelde of Willebroekse Vaart". Te Charleroi wordt het kanaal gevoed door de Samber. Het staat tevens in verbinding met het Canal du Centre. Het kanaal loopt noordwaarts door Pont-à-Celles, Manage, Ronquières, Clabecq en komt te Lembeek op Vlaams grondgebied. Vervolgens loopt het doorheen Halle, Buizingen, Huizingen, Lot en Ruisbroek tot in het Brussels Gewest. Het deel tussen Lembeek en Ruisbroek is ongeveer $10 \mathrm{~km}$ lang, heeft een gemiddelde breedte van $40 \mathrm{~m}$ en een diepte van 3 m. Opwaarts de Brusselse agglomeratie wordt water van de Zenne aangevoerd. Verder noordwaarts, hier de Willebroekse Vaart of Kanaal Brussel-Schelde genoemd, verlaat het kanaal het Brussels gewest via Vilvoorde en loopt doorheen Ramsdonk, Tisselt, Willebroek en Niel om er aan te sluiten op de Rupel. Sinds kort is het kanaal via de Wintham sluis in verbinding gesteld met de Schelde. Het kanaal is van Brussel tot aan de monding in de Rupel ongeveer $18 \mathrm{~km}$ lang, de breedte varieert en heeft een gemiddelde van $50 \mathrm{~m}$, de diepte varieert van $6.5 \mathrm{~m}$ tot $9.5 \mathrm{~m}$. Het Kanaal Charleroi-Brussel-Schelde is door de aanwezigheid van verschillende sluizen (te Lembeek, Halle, Lot, Ruisbroek, Anderlecht, St. Jans-Molenbeek, Zemst en Wintham) 
opgedeeld in verschillende panden (Van Thuyne, 2003). Op het kanaal werden twee vistechnieken toegepast.

\subsubsection{Abiotische data op het moment van de staalnames}

Op het moment van de staalnames werden geen uitzonderlijk hoge of lage waarden van de waterkwaliteit parameters gemeten (Tabel 33).

Tabel 33: Overzicht van de omgevingsvariabelen gemeten op het moment van de staalnames in het kanaal.

\begin{tabular}{|c|c|c|c|c|c|c|c|c|c|}
\hline Waterloop & Code & Datum & Watertemperatuur $\left({ }^{\circ} \mathrm{C}\right)$ & $\mathrm{O}_{2}(\mathrm{mg} / \mathrm{l})$ & $\mathrm{O}_{2}(\%)$ & $\mathrm{pH}$ & Turbiditeit (NTU) & Saliniteit (\%) & Conductiviteit $(\mu \mathrm{S} / \mathrm{cm})$ \\
\hline Kanaal Brussel Charleroi & C1 & $25 / 05 / 2016$ & 17,9 & 9,49 & 100,3 & 7,5 & 29,6 & 0,36 & 632 \\
\hline Kanaal Brussel Charleroi & $\mathrm{C} 2$ & $25 / 05 / 2016$ & 19,6 & 5,62 & 61,4 & 7,43 & 17,9 & 0,43 & 776 \\
\hline Kanaal Brussel Charleroi & C1 & $18 / 10 / 2016$ & 13,5 & 10,02 & 96,7 & 8,11 & & 0,39 & 624 \\
\hline Kanaal Brussel Charleroi & $\mathrm{C} 1$ & 20/10/2016 & 13,6 & 9,33 & 90,4 & 8,16 & & 0,38 & 601 \\
\hline Kanaal Brussel Charleroi & $\mathrm{C} 2$ & 20/10/2016 & 15,9 & 7,68 & & 7,97 & & & 680 \\
\hline
\end{tabular}

\subsubsection{Resultaten vismonitoring}

In het voorjaar en in het najaar werden beide locaties elektrisch afgevist van op een boot. Per locatie plaatsten we langs elke oever twee schietfuiken voor een periode van 48 uur in het voorjaar en een fuik langs elke oever in het najaar (Tabel 34).

Tabel 34: Specificaties van de gebruikte technieken voor het afvissen in kanaal Brussel Charleroi in 2016.

\begin{tabular}{|c|c|c|c|c|c|c|c|}
\hline Waterloop & Code & Datum & Afvissingstechniek & Lengte transect $(\mathrm{m})$ & Breedte transect $(\mathrm{m})$ & Oppervlakte van transect $\left(\mathrm{m}^{2}\right)$ & Fuikdagen \\
\hline Kanaal Brussel Charleroi & C1 & $25 / 05 / 2016$ & fuik & & & & 8 \\
\hline Kanaal Brussel Charleroi & $\mathrm{C} 2$ & $25 / 05 / 2016$ & fuik & & & & 8 \\
\hline Kanaal Brussel Charleroi & $\mathrm{C} 1$ & $25 / 05 / 2016$ & elektrisch & 600 & 2,5 & 1500 & \\
\hline Kanaal Brussel Charleroi & $\mathrm{C} 2$ & $25 / 05 / 2016$ & elektrisch & 500 & 2,5 & 1250 & \\
\hline Kanaal Brussel Charleroi & $\mathrm{C} 1$ & $18 / 10 / 2016$ & elektrisch & 500 & 2,5 & 1250 & \\
\hline Kanaal Brussel Charleroi & $\mathrm{C} 1$ & $20 / 10 / 2016$ & fuik & & & & 4 \\
\hline Kanaal Brussel Charleroi & $\mathrm{C} 2$ & $18 / 10 / 2016$ & elektrisch & 500 & 2,5 & 1250 & \\
\hline Kanaal Brussel Charleroi & $\mathrm{C} 2$ & 20/10/2016 & fuik & & & & 4 \\
\hline
\end{tabular}

\subsection{Elektrische visvangst resultaten}

Met de elektrische visvangst werden weinig soorten gevangen. Zoals in vorige rapportages gemeld blijft het moeilijk om vissen op deze manier te vangen in het kanaal. Op locatie C2 werden heel veel zwartbekgrondels gevangen (Tabel 35; Figuur 19). Deze soort werd daar voor het eerst in 2013 gevangen. Deze invasieve exotische soort domineert het visbestand. Verder vingen we in 2016 meer soorten in het voorjaar dan in het najaar. 
Tabel 35: Overzicht van aantal individuen elektrisch gevangen per soort en per locatie tijdens de verschillende campagnes in het kanaal Brussel Charleroi.

\begin{tabular}{|c|c|c|c|c|c|c|c|c|c|c|}
\hline Locatie & $\mathrm{C} 1$ & $\mathrm{C} 1$ & $\mathrm{C} 1$ & $\mathrm{C} 1$ & $\mathrm{C} 1$ & $\mathrm{C} 2$ & $\mathrm{C} 2$ & $\mathrm{C} 2$ & $\mathrm{C} 2$ & $\mathrm{C} 2$ \\
\hline Datum & $10 / 05 / 2004$ & $23 / 10 / 2007$ & $16 / 10 / 2013$ & $25 / 05 / 2016$ & $18 / 10 / 2016$ & $10 / 05 / 2004$ & $23 / 10 / 2007$ & $16 / 10 / 2013$ & $25 / 05 / 2016$ & $18 / 10 / 2016$ \\
\hline baars & 3 & 4 & 118 & 20 & 14 & 0 & 10 & 18 & 0 & 1 \\
\hline bittervoorn & 0 & 0 & 8 & 5 & 11 & 0 & 0 & 0 & 0 & 0 \\
\hline blankvoorn & 155 & 30 & 41 & 9 & 2 & 1 & 0 & 5 & 0 & 0 \\
\hline blauwbandgrondel & 0 & 0 & 5 & 0 & 0 & 0 & 0 & 0 & 0 & 0 \\
\hline driedoornige stekelbaars & 0 & 0 & 1 & 0 & 0 & 0 & 0 & 0 & 0 & 0 \\
\hline giebel & 0 & 0 & 1 & 0 & 0 & 0 & 0 & 0 & 0 & 0 \\
\hline karper & 0 & 0 & 0 & 1 & 0 & 0 & 0 & 0 & 0 & 0 \\
\hline paling & 0 & 1 & 2 & 3 & 0 & 0 & 0 & 0 & 0 & 0 \\
\hline rietvoorn & 0 & 0 & 5 & 3 & 0 & 0 & 0 & 1 & 0 & 0 \\
\hline riviergrondel & 3 & 0 & 0 & 0 & 2 & 0 & 0 & 0 & 0 & 0 \\
\hline serpeling & 0 & 1 & 1 & 0 & 0 & 0 & 0 & 0 & 0 & 0 \\
\hline snoekbaars & 1 & 1 & 1 & 0 & 0 & 0 & 0 & 0 & 1 & 0 \\
\hline winde & 0 & 3 & 2 & 0 & 0 & 0 & 0 & 0 & 0 & 0 \\
\hline zwartbekgrondel & 0 & 0 & 0 & 0 & 0 & 0 & 0 & 4 & 43 & 577 \\
\hline Totaal aantal soorten & 4 & 6 & 11 & 6 & 4 & 1 & 1 & 4 & 2 & 2 \\
\hline Totaal aantal individuen & 162 & 40 & 185 & 41 & 29 & 1 & 10 & 28 & 44 & 578 \\
\hline
\end{tabular}

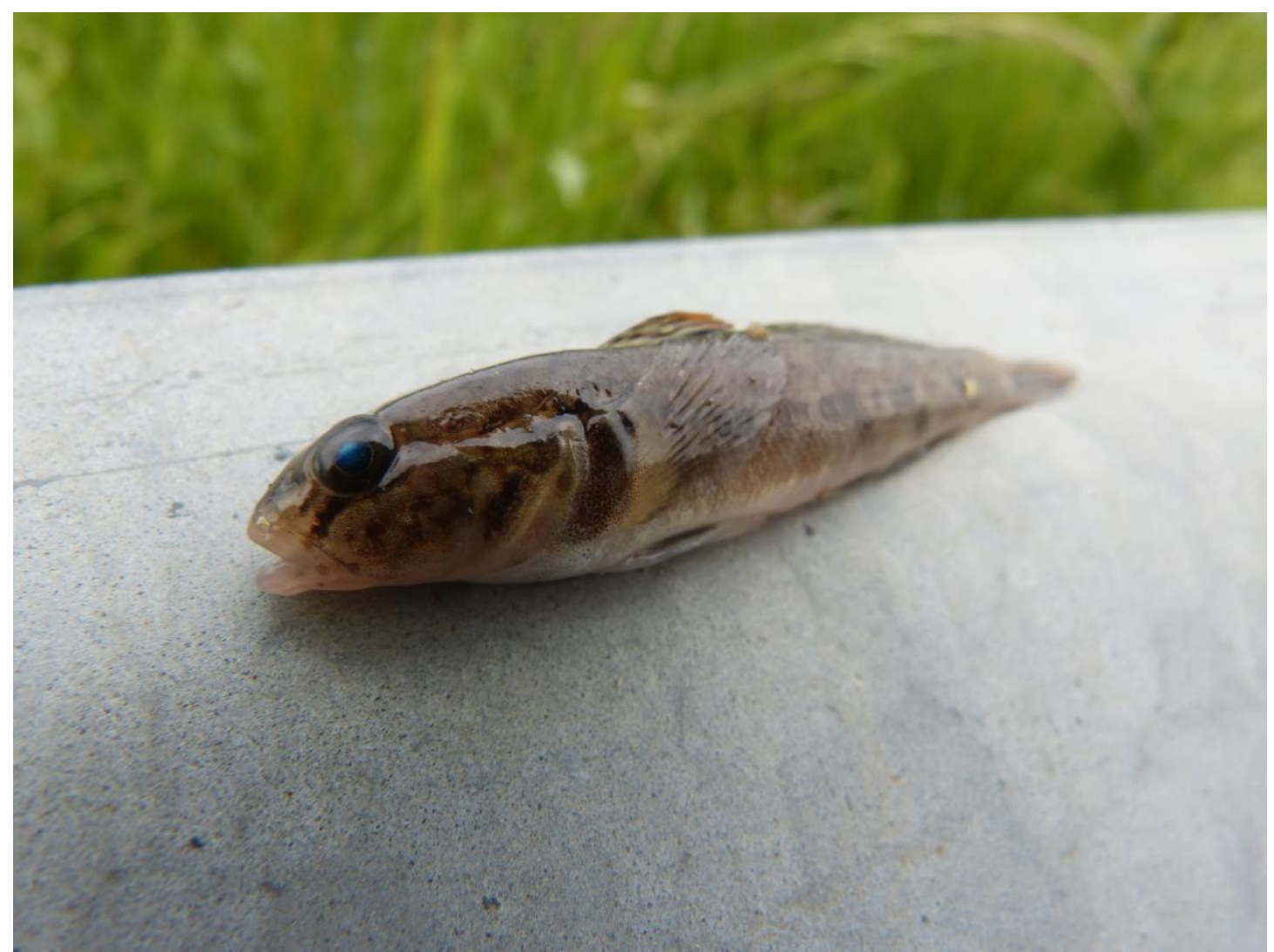

Figuur 19: Zwartbekgrondel (Neogobius melanostomus) gevangen in het kanaal (foto Stijn Van Onsem).

In het voorjaar van 2016 waren de gevangen baarzen op locatie $\mathrm{C} 1$ gemiddeld 12,7 $\mathrm{cm}$ lang met een gemiddeld gewicht van $29,4 \mathrm{~g}$. De gemiddelde lengte van blankvoorn gevangen in het voorjaar op locatie C1 was $13,4 \mathrm{~cm}$ met een gemiddeld gewicht van $35,4 \mathrm{~g}$. Op C1 vingen we enkele juveniele rietvoorns met een gemiddelde lengte van $7,1 \mathrm{~cm}$ en een gemiddeld gewicht van $2,9 \mathrm{~g}$. In het voorjaar 
vingen we op C1 een karper van 58,5 cm met een gewicht van 3066,2 g (Tabel 36) De snoekbaars gevangen op C2 in het voorjaar was een larve van $2,1 \mathrm{~cm}$ lang.

Tabel 36: Overzicht van totaal gewicht (in g) gevangen met elektrische visvangst per soort en per locatie tijdens de verschillende campagnes in het kanaal Brussel Charleroi.

\begin{tabular}{|c|c|c|c|c|c|c|c|c|c|c|}
\hline Locatie & C1 & C1 & $\mathrm{C} 1$ & C1 & C1 & C2 & C2 & C2 & C2 & C2 \\
\hline Datum & $10 / 05 / 2004$ & $23 / 10 / 2007$ & $16 / 10 / 2013$ & $25 / 05 / 2016$ & $18 / 10 / 2016$ & $10 / 05 / 2004$ & $23 / 10 / 2007$ & $16 / 10 / 2013$ & $25 / 05 / 2016$ & $18 / 10 / 2016$ \\
\hline baars & 156,3 & 75,2 & 3550 & 589,3 & 642,4 & 0 & 97,4 & 179,1 & 0 & 12,5 \\
\hline bittervoorn & 0 & 0 & 16,7 & 10,3 & 13,6 & 0 & 0 & 0 & 0 & 0 \\
\hline blankvoorn & 3343,9 & 1376,3 & 1021,5 & 318,6 & 8,4 & 12,3 & 0 & 52,2 & 0 & 0 \\
\hline blauwbandgrondel & 0 & 0 & 25,3 & 0 & 0 & 0 & 0 & 0 & 0 & 0 \\
\hline driedoornige stekelbaars & 0 & 0 & 0,3 & 0 & 0 & 0 & 0 & 0 & 0 & 0 \\
\hline giebel & 0 & 0 & 33,5 & 0 & 0 & 0 & 0 & 0 & 0 & 0 \\
\hline karper & 0 & 0 & 0 & 3066,2 & 0 & 0 & 0 & 0 & 0 & 0 \\
\hline paling & 0 & 76,7 & 1144 & 826,1 & 0 & 0 & 0 & 0 & 0 & 0 \\
\hline rietvoorn & 0 & 0 & 117,4 & 8,7 & 0 & 0 & 0 & 1,4 & 0 & 0 \\
\hline riviergrondel & 99,1 & 0 & 0 & 0 & 7,7 & 0 & 0 & 0 & 0 & 0 \\
\hline serpeling & 0 & 11,6 & 0,7 & 0 & 0 & 0 & 0 & 0 & 0 & 0 \\
\hline snoekbaars & 103,1 & 7,7 & 30,4 & 0 & 0 & 0 & 0 & 0 & 0,2 & 0 \\
\hline winde & 0 & 99,5 & 759,1 & 0 & 0 & 0 & 0 & 0 & 0 & 0 \\
\hline zwartbekgrondel & 0 & 0 & 0 & 0 & 0 & 0 & 0 & 17,8 & 81,4 & 759,7 \\
\hline totaal gewicht & 3702,4 & 1647 & 6698,9 & 4819,2 & 672,1 & 12,3 & 97,4 & 250,5 & 81,6 & 772,2 \\
\hline
\end{tabular}

De biomassa gevangen in C1 is altijd hoger dan in C2.

\subsection{Fuikvangsten}

Met fuiken vingen we in 2016 meer soorten dan met de elektrische visserij. Brasem, kolblei, pos en zeelt werden in geen enkele campagne elektrisch gevangen. Winde, serpeling en driedoornige stekelbaars werden nooit met fuiken gevangen.

In $\mathrm{C} 1$ vingen we in het voorjaar van 201610 soorten en 6 in het najaar. Baars werd in C1 zowel in het voorjaar als najaar gevangen. In het voorjaar van 2016 vingen we op locatie C1 baarzen met een gemiddelde lengte van $13,7 \mathrm{~cm}$ en een gemiddeld gewicht van $43 \mathrm{~g}$. Dat stemt goed overeen met de elektrisch gevangen baarzen op deze locatie. In het najaar was de lengte van de met fuiken gevangen baarzen op locatie C1 gemiddeld $14,1 \mathrm{~cm}$ met een gemiddeld gewicht van $43,7 \mathrm{~g}$. De gemiddelde lengte van blankvoorn gevangen met fuiken in het voorjaar op locatie C1 was zeer vergelijkbaar met de elektrische vangsten $\mathrm{nl} .13,4 \mathrm{~cm}$ met een gemiddeld gewicht van $31,9 \mathrm{~g}$. De gevangen rietvoorn met fuiken in het voorjaar was wel gemiddeld groter dan de elektrisch gevangen exemplaren: $20,5 \mathrm{~cm}$ en 116,7 g gemiddeld. $\mathrm{Er}$ werd op C1 in het voorjaar van 2016 één volwassen brasem gevangen $(45,9 \mathrm{~cm}$; $1193,4 \mathrm{~g}$ ) en 8 juveniele brasems met een gemiddelde lengte en gewicht van $7,2 \mathrm{~cm}$ en 4,6 g. De snoekbaarzen in het voorjaar gevangen in C2 waren jonge exemplaren variërend van lengte tussen de 3,5 en $17,6 \mathrm{~cm}$.

In C2 vingen we in beide campagnes in 20167 soorten. In het voorjaar van 2016 vingen we op locatie C2 baarzen met een gemiddelde lengte van $18,2 \mathrm{~cm}$ en een gemiddeld gewicht van $141,6 \mathrm{~g}$. Dat waren duidelijke gemiddeld grotere exemplaren dan in $\mathrm{C} 1$. In het najaar weren de gevangen baars exemplaren iets kleiner: gemiddeld $15 \mathrm{~cm}$ met een gemiddeld gewicht van $84,8 \mathrm{~cm}$. De snoekbaarzen gevangen in C2 waren in het voorjaar van 2016 een mengeling van juveniele (gem. $3.6 \mathrm{~cm}$ ) en volwassen exemplaren (gem. 20,3 cm). In het najaar van 2016 werden op 
deze locatie enkel volwassen snoekbaarzen gevangen met een gemiddelde lengte en gewicht van $33 \mathrm{~cm}$ en 560,6 g. De karper in C2 was 28,8 cm lang met een gewicht van $420,6 \mathrm{~g}$ (Tabel 38).

Tabel 37: Overzicht van aantal individuen met fuiken gevangen per soort en per locatie tijdens de verschillende campagnes in het kanaal Brussel Charleroi.

\begin{tabular}{|c|c|c|c|c|c|c|c|c|c|c|c|c|}
\hline Locatie & C1 & C1 & C1 & C1 & C1 & $\mathrm{C} 1$ & $\mathrm{C} 2$ & $\mathrm{C} 2$ & $\mathrm{C} 2$ & $\mathrm{C} 2$ & $\mathrm{C} 2$ & C2 \\
\hline Datum & $10 / 05 / 2004$ & $10 / 07 / 2004$ & $24 / 10 / 2007$ & $18 / 10 / 2013$ & $25 / 05 / 2016$ & $20 / 10 / 2016$ & $10 / 05 / 2004$ & $10 / 07 / 2004$ & $24 / 10 / 2007$ & $18 / 10 / 2013$ & $25 / 05 / 2016$ & $20 / 10 / 2016$ \\
\hline baars & 3 & 0 & 5 & 10 & 20 & 3 & 20 & 20 & 19 & 11 & 6 & 3 \\
\hline bittervoorn & 0 & 0 & 0 & 0 & 1 & 0 & 0 & 0 & 0 & 0 & 0 & 0 \\
\hline blankvoorn & 221 & 65 & 77 & 83 & 52 & 52 & 71 & 70 & 12 & 0 & 0 & 1 \\
\hline blauwbandgrondel & 0 & 0 & 0 & 0 & 1 & 0 & 1 & 1 & 0 & 0 & 0 & 0 \\
\hline brasem & 0 & 0 & 0 & 3 & 9 & 0 & 0 & 0 & 0 & 4 & 0 & 1 \\
\hline giebel & 1 & 1 & 0 & 0 & 0 & 1 & 0 & 0 & 2 & 0 & 1 & 0 \\
\hline karper & 2 & 2 & 0 & 0 & 0 & 0 & 4 & 4 & 2 & 0 & 1 & 2 \\
\hline kolblei & 19 & 19 & 15 & 1 & 5 & 1 & 0 & 0 & 0 & 4 & 0 & 1 \\
\hline paling & 10 & 10 & 3 & 13 & 23 & 9 & 12 & 12 & 8 & 19 & 23 & 2 \\
\hline pos & 5 & 5 & 0 & 2 & 26 & 0 & 11 & 11 & 0 & 0 & 0 & 0 \\
\hline rietvoorn & 0 & 0 & 0 & 2 & 2 & 0 & 12 & 12 & 0 & 1 & 0 & 0 \\
\hline riviergrondel & 5 & 2 & 0 & 0 & 0 & 0 & 0 & 0 & 0 & 0 & 0 & 0 \\
\hline snoekbaars & 2 & 1 & 2 & 9 & 18 & 4 & 4 & 4 & 2 & 10 & 42 & 10 \\
\hline zeelt & 0 & 0 & 0 & 0 & 0 & 0 & 1 & 1 & 0 & 0 & 2 & 0 \\
\hline zwartbekgrondel & 0 & 0 & 0 & 0 & 0 & 0 & 0 & 0 & 0 & 0 & 2 & 0 \\
\hline Totaal aantal soorten & 9 & 8 & 5 & 8 & 10 & 6 & 9 & 9 & 6 & 6 & 7 & 7 \\
\hline Totaal aantal individuen & 268 & 105 & 102 & 123 & 157 & 70 & 136 & 135 & 45 & 49 & 77 & 20 \\
\hline
\end{tabular}

Zwartbekgrondel werd minder gevangen met de fuiken dan met de elektrische visserij.

Voor de periode 2004-2016 dragen paling, blankvoorn, karper en snoekbaars het meest bij tot de biomassa (Tabel 38).

Tabel 38: Overzicht van totaal gewicht (in g) gevangen met fuiken per soort en per locatie tijdens de verschillende campagnes in het kanaal Brussel Charleroi.

\begin{tabular}{|c|c|c|c|c|c|c|c|c|c|c|c|c|}
\hline Locatie & C1 & C1 & C1 & C1 & C1 & C1 & $\mathrm{C} 2$ & $\mathrm{C} 2$ & C2 & C2 & C2 & $\mathrm{C} 2$ \\
\hline Datum & $10 / 05 / 2004$ & $10 / 07 / 2004$ & $24 / 10 / 2007$ & $18 / 10 / 2013$ & $25 / 05 / 2016$ & $20 / 10 / 2016$ & $10 / 05 / 2004$ & $10 / 07 / 2004$ & $24 / 10 / 2007$ & $18 / 10 / 2013$ & $25 / 05 / 2016$ & $20 / 10 / 2016$ \\
\hline baars & 156,3 & 0 & 90,6 & 145,4 & 860,9 & 47,7 & 877,9 & 877,9 & 823,6 & 1510 & 849,5 & 461,5 \\
\hline bittervoorn & 0 & 0 & 0 & 0 & 4,8 & 0 & 0 & 0 & 0 & 0 & 0 & 0 \\
\hline blankvoorn & 6572 & 3145,7 & 3361,5 & 2627,9 & 1662,7 & 3349 & 6046,9 & 6034,6 & 1332,4 & 0 & 0 & 250,8 \\
\hline blauwbandgrondel & 0 & 0 & 0 & 0 & 5 & 0 & 8 & 8 & 0 & 0 & 0 & 0 \\
\hline brasem & 0 & 0 & 0 & 1299,5 & 1230,2 & 0 & 0 & 0 & 0 & 1421,5 & 0 & 1107,8 \\
\hline giebel & 967,4 & 967,4 & 0 & 0 & 0 & 220,4 & 0 & 0 & 703,2 & 0 & 580,8 & 0 \\
\hline karper & 3082,7 & 3082,7 & 0 & 0 & 0 & 0 & 4488,2 & 4488,2 & 1543,4 & 0 & 420,6 & 3217,3 \\
\hline kolblei & 2680,8 & 2680,8 & 898,8 & 46 & 819,7 & 68,3 & 0 & 0 & 0 & 423,5 & 0 & 8,5 \\
\hline paling & 3798,3 & 3798,3 & 834,6 & 5935 & 9130,6 & 6043 & 1795,3 & 1795,3 & 2599 & 11353 & 8040,1 & 2135,4 \\
\hline pos & 58,6 & 58,6 & 0 & 27 & 490,9 & 0 & 435,3 & 435,3 & 0 & 0 & 0 & 0 \\
\hline rietvoorn & 0 & 0 & 0 & 49,2 & 233,4 & 0 & 1951 & 1951 & 0 & 189,7 & 0 & 0 \\
\hline riviergrondel & 159 & 59,9 & 0 & 0 & 0 & 0 & 0 & 0 & 0 & 0 & 0 & 0 \\
\hline snoekbaars & 159,1 & 56 & 401,8 & 388,6 & 396 & 5548,8 & 97,4 & 97,4 & 624,8 & 3648,2 & 842,7 & 2299,9 \\
\hline zeelt & 0 & 0 & 0 & 0 & 0 & 0 & 328,7 & 328,7 & 0 & 0 & 2534,1 & 0 \\
\hline zwartbekgrondel & 0 & 0 & 0 & 0 & 0 & 0 & 0 & 0 & 0 & 0 & 22,4 & 0 \\
\hline totaal gewicht & 17634,2 & 13849,4 & 5587,3 & 10518,6 & 14834,2 & 15277,2 & 16028,7 & 16016,4 & 7626,4 & 18545,9 & 13290,2 & 9481,2 \\
\hline
\end{tabular}

Het kanaal Brussel Charleroi herbergt een gevarieerd visbestand. De stijgende aanwezigheid van zwartbekgrondel is een slechte evolutie. Deze exotische soort wordt algemeen in veel waterlopen in Vlaanderen aangetroffen en is als een pest te beschouwen.

We kunnen de waargenomen verschillen tussen beide visserij technieken aantonen met een ordinatie op basis van een ééntoppig (DCA) responsmodel (Figuur 20). Hierbij gebruiken we de data van alle campagnes 204-2016. Om de data statistisch te 
vergelijken werden alle gegevens omgerekend naar relatieve abundantie (\% van de totale vangst per locatie en per seizoen). We voerden met deze getransformeerde data een verkennende visuele analyse uit door middel van een NMDS-ordinatie (Non-Metric Multidimensial Scaling) om zowel ruimtelijke als seizoenale patronen te visualiseren. We namen als afstandsmaat Bray-Curtis omdat deze methode rekening houdt met zowel aantallen als soorten.

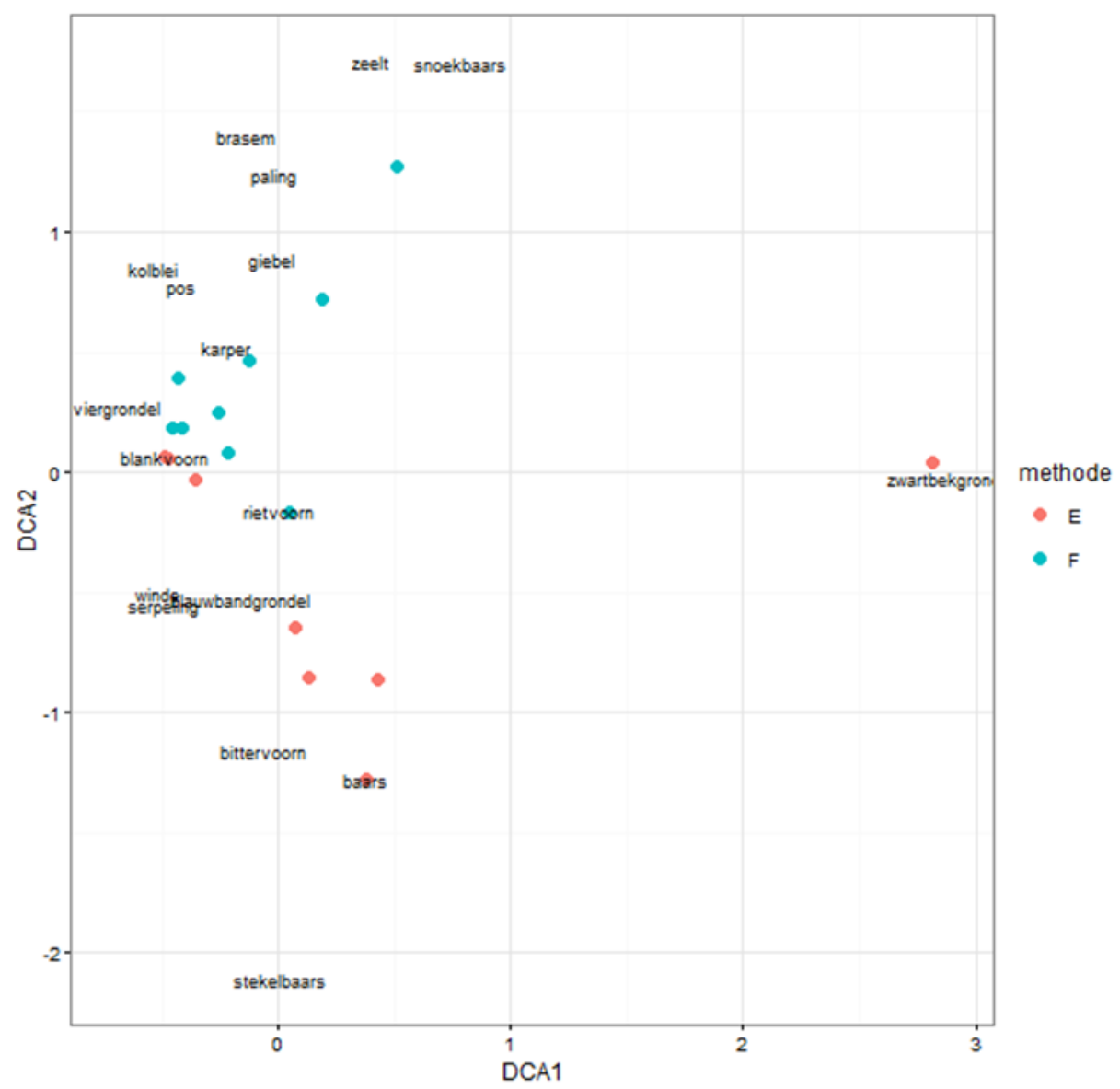

Figuur 20: NMDS-ordinatie van de vangsten $(n=18)$ in functie van de methodes, op basis van de relatieve abundantie gegevens tijdens de campagnes in de periode 2004-2016. F: fuikvangsten; E: elektrische visserij (eigenwaarden eerste en tweede as: 0,7333 en 0,4403).

Uit Figuur 20 blijkt dat de technieken verschillende resultaten geven.

Dezelfde resultaten kunnen ook per locatie worden weergegeven (Figuur 21). Hieruit is duidelijk dat $\mathrm{C} 1$ en $\mathrm{C} 2$ verschillen wat de vissamenstelling betreft. $\mathrm{Er}$ is ook een grotere variatie in $\mathrm{C} 2$ dan in $\mathrm{C} 1$. 


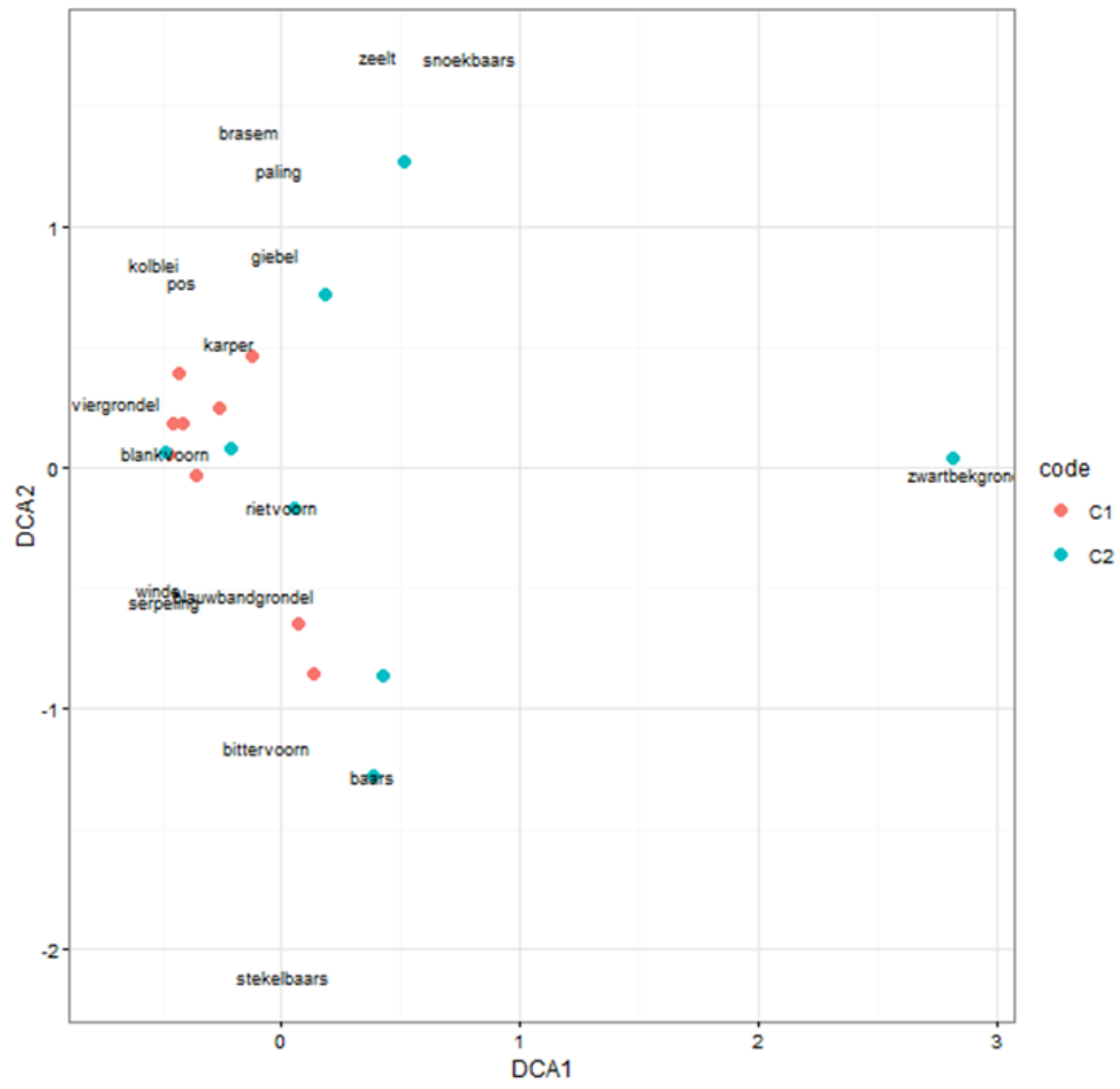

Figuur 21: NMDS-ordinatie van de vangsten $(n=18)$ in functie van de locatie, op basis van de relatieve abundantie gegevens tijdens de campagnes in de periode 2004-2016. (eigenwaarden eerste en tweede as: 0,7333 en 0,4403).

Dezelfde analyse uitgevoerd met voorjaar en najaar gecombineerde vangst data, elektrisch en fuikvisserij samen, toont duidelijk seizoenale verschillen (Figuur 22). 


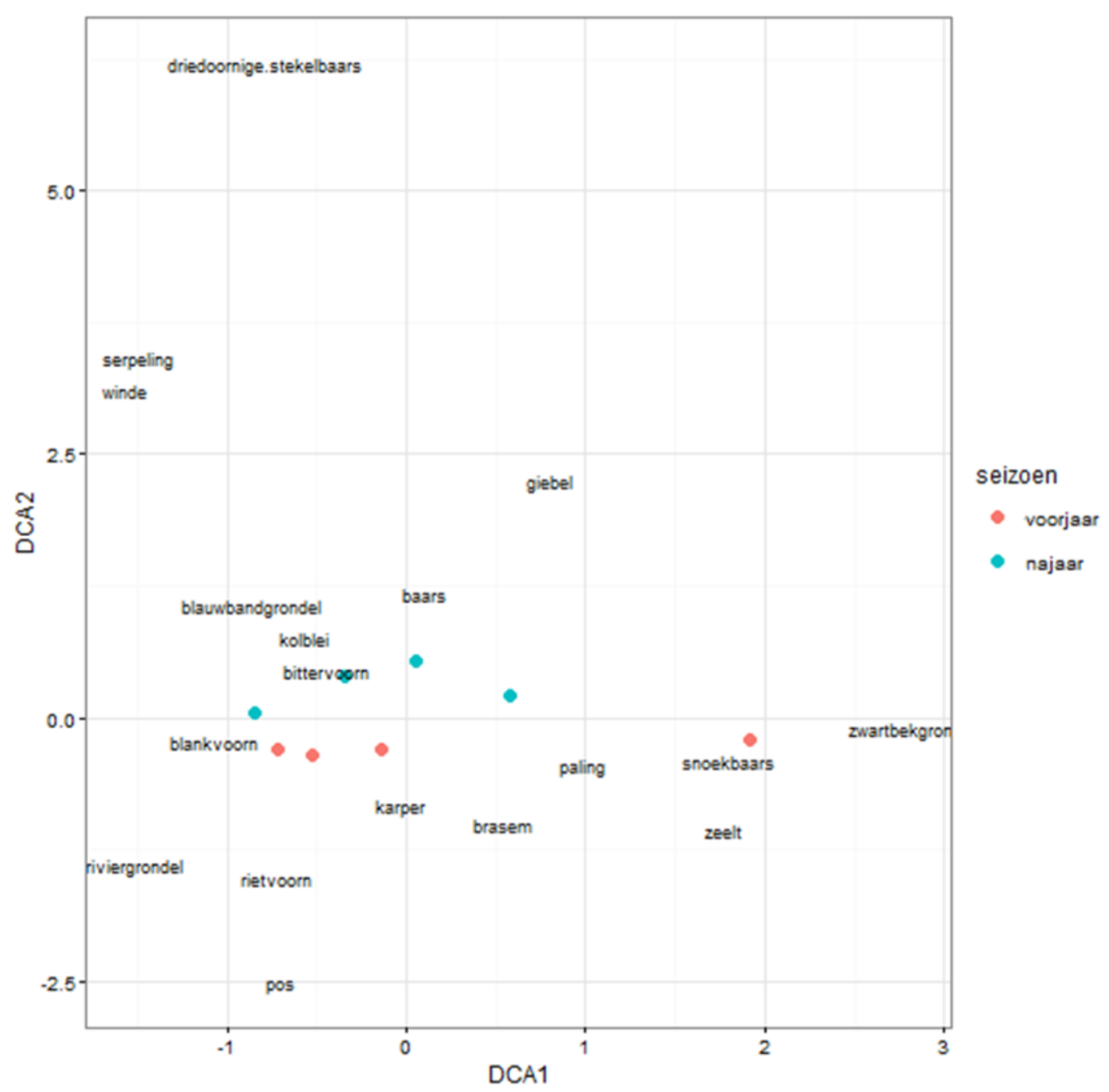

Figuur 22: NMDS-ordinatie van de vangsten $(n=8)$ in functie van het seizoen, op basis van de relatieve abundantie gegevens (fuik en elektrische visserij samen) tijdens de campagnes in de periode 20042016. (eigenwaarden eerste en tweede as: 0,5298 en 0,1347).

Een herhaling van de analyse maar nu in functie van de locatie toont opnieuw aan dat beide locaties verschillen wat de gevangen visgemeenschap betreft (Figuur 23). 


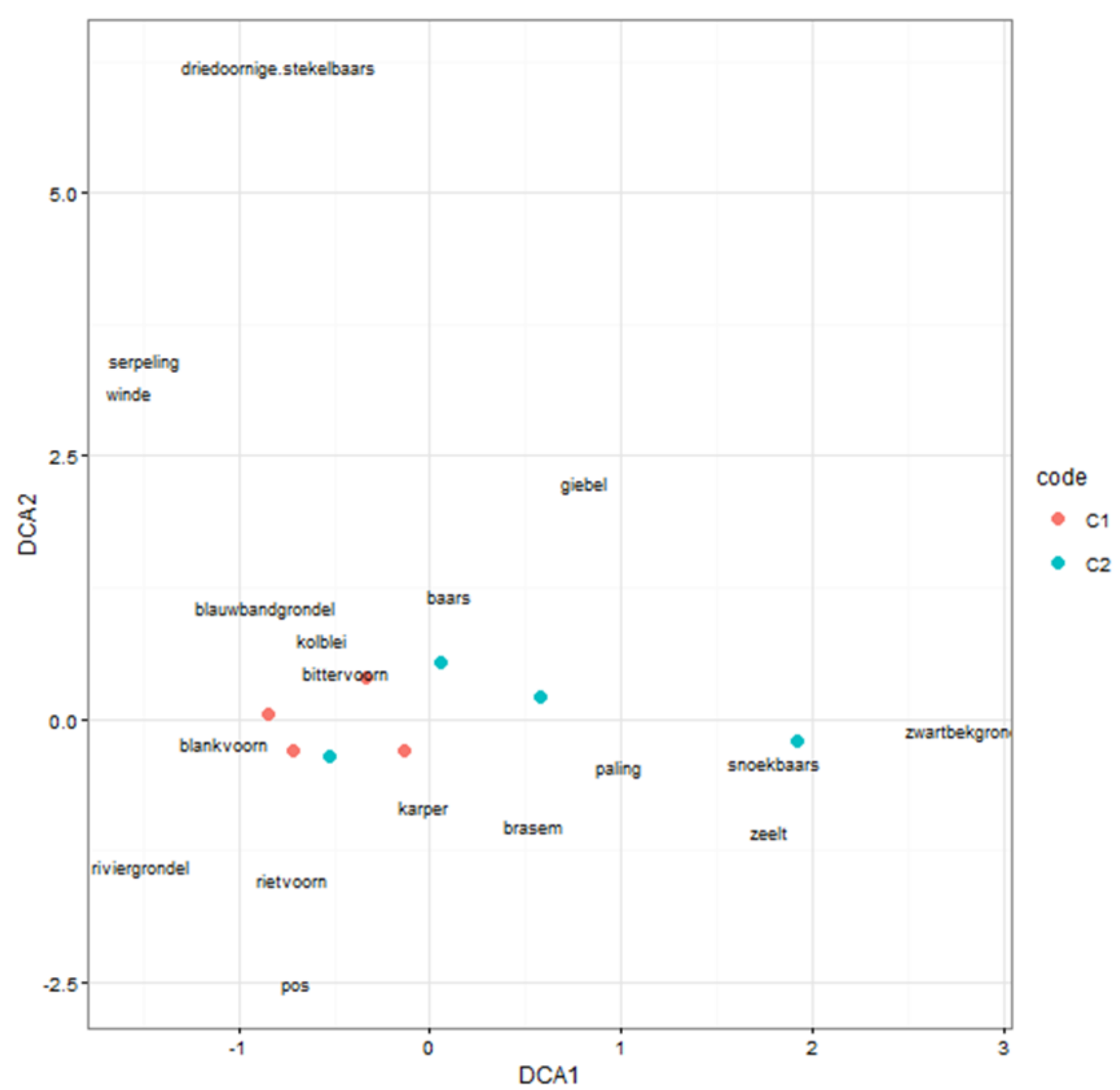

Figuur 23: NMDS-ordinatie van de vangsten $(n=8)$ in functie van de locatie, op basis van de relatieve abundantie gegevens (fuik en elektrische visserij samen) tijdens de campagnes in de periode 20042016. (eigenwaarden eerste en tweede as: 0,5298 en 0,1347).

\subsection{Overzicht van de beoordeling op basis van de type-specifieke} visindices

\subsubsection{De Zenne}

De Zenne was in 2004 en 2007 op beide locaties "dood" gezien er geen visleven werd aangetroffen. In 2013 bleef één locatie (S2) visloos terwijl slechts één vis werd gevangen stroomafwaarts het RWZI van Brussel Noord (S4). Deze locatie scoorde toen "slecht" met een EQR gelijk aan 0,21. In 2016 werd er in de zomer en het najaar gevist met elektriciteit. In beide locaties werden vissen gevangen en kan dus een index berekend worden. 
Tabel 39: Gebruikte afkorting en verklaring metrieken voor bereken EQR grote rivier.

\begin{tabular}{l}
\hline afkorting verklaring \\
\hline MNSTOT Totaal aantal soorten \\
MANTROF Trofische compositie \\
MANSHA Shannon-Wiener \\
MANMIG Migratie waarde \\
MANREF Referentie soorten \\
MANTOL Gemiddelde tolerantiewaarde \\
MANGKW Lengteklasse waarde
\end{tabular}

Zowel in de zomer als in het najaar van 2016 halen beide locaties in de Zenne een "slechte" waterkwaliteit. Nochtans is de EQR toegenomen in beide locaties: 0,27 in de zomer en 0,29 in het najaar.

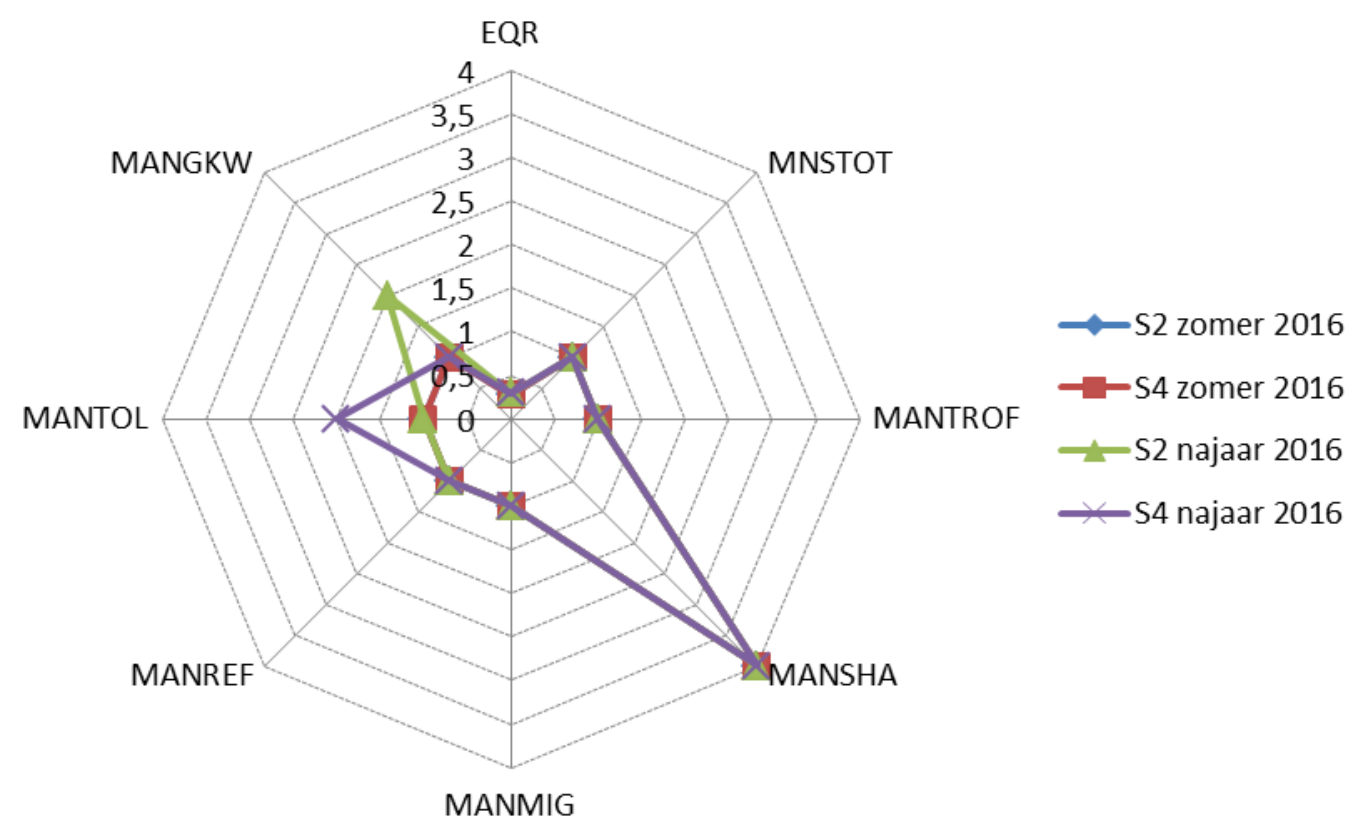

Figuur 24: EQR en metriekscores voor de Zenne op twee locaties in de zomer en het najaar van 2016.

De metriek Shannon-Wiener scoort goed in alle locaties (4). De overige metrieken doen het minder goed.

De fuikvangsten toonden wel aan dat er meer soorten aanwezig zijn dan dat er gevangen worden met elektriciteit. In de fuiken vingen we referentiesoorten die niet gevangen werden met de elektrische visserij. De sterke stroming in de Zenne bemoeilijkt het elektrisch vissen. Misschien moet in de toekomst een methode ontwikkeld worden naar analogie met deze van de kanalen waarbij twee technieken gebruikt worden voor het berekenen van de EQR. 
Op basis van alle vangsten samen werd de globale kwaliteit van de Zenne in het Brussels gewest in 2016 bepaald (Figuur 25). De Zenne scoort met een EQR van 0,35 "onvoldoende" wanneer geïntegreerd wordt over beide staalnamelocaties en vangstmomenten.

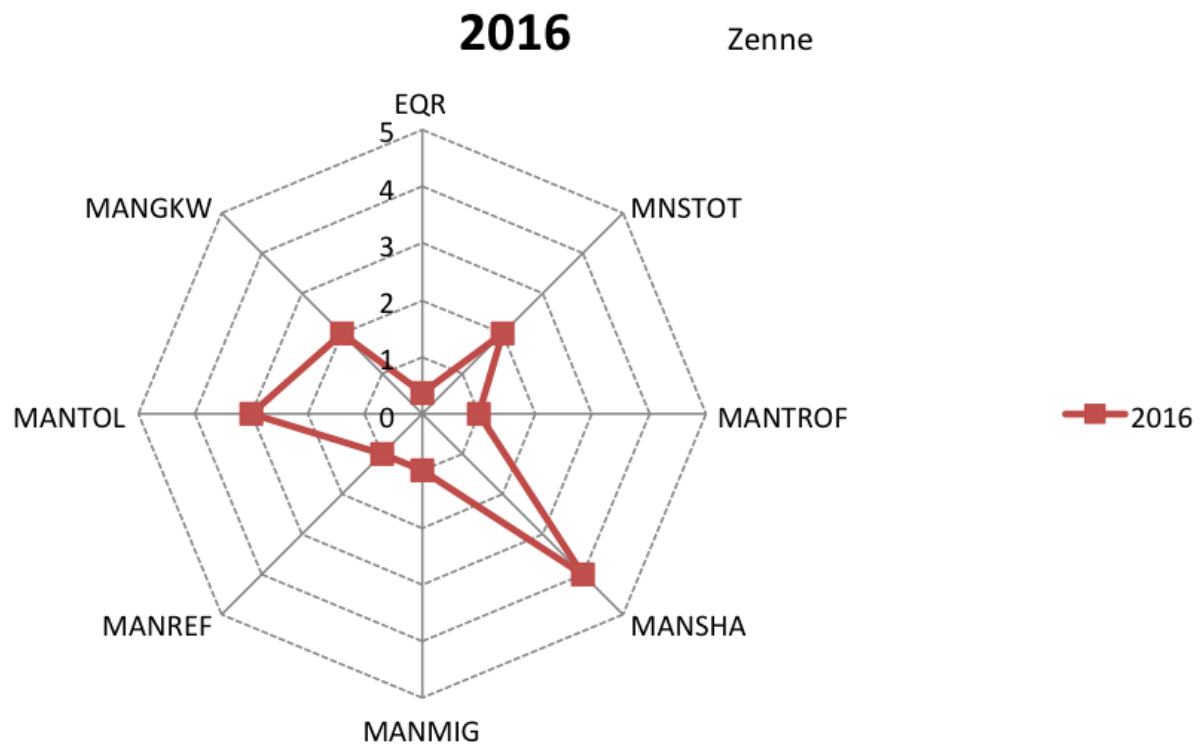

Figuur 25: Globale EQR en metriekscores voor de Zenne in 2016.

\subsubsection{De Woluwe}

In 2004 scoorde de Woluwe "matig" met 0,50 als EQR waarde. In 2007 en 2013 scoorde de Woluwe "ontoereikend" met EQR waarden 0,47 en 0,36. De ecologische toestand van de Woluwe in 2013 was "ontoereikend" mede door het ontbreken van soorten als snoek, zeelt en rietvoorn. Snoek is een gevoelige soort en zijn afwezigheid wijst op een verstoring. In 2016 werd er zowel in het voorjaar als in het najaar gevist. Voor beide campagnes scoort de EQR “ontoereikend" (Figuur 26). In het voorjaar is de EQR 0,33 en 0,43 in het najaar. In het voorjaar scoort de metriek aantal soorten lager ( 7 soorten $=$ score 2 ) dan in het najaar ( 8 soorten $=$ score 3 ). Het relatief percentage piscivoren blijft laag ook al werd in het najaar wel snoek gevangen. Het relatief percentage omnivoren blijft hoog (12 en 11\% in het voor-en najaar). De Shannon-Wiener index scoort matig in het voorjaar en ontoereikend in het najaar. In het najaar haalt het hoge aantal bittervoorn de 'evenness' naar beneden. Evenness is een maat voor de relatieve abundantie. Wanneer een of enkele soorten de aantallen domineren daalt de waarde van de evenness. De metrieken die de migrerende soorten evalueren (ManMig) en de grootte klasse waarde (ManGkw) scoren nog te laag. De laatste metriek evalueert het percentage rekrutering wat in beide seizoenen te laag was ( 28 en $50 \%$ respectievelijk). 


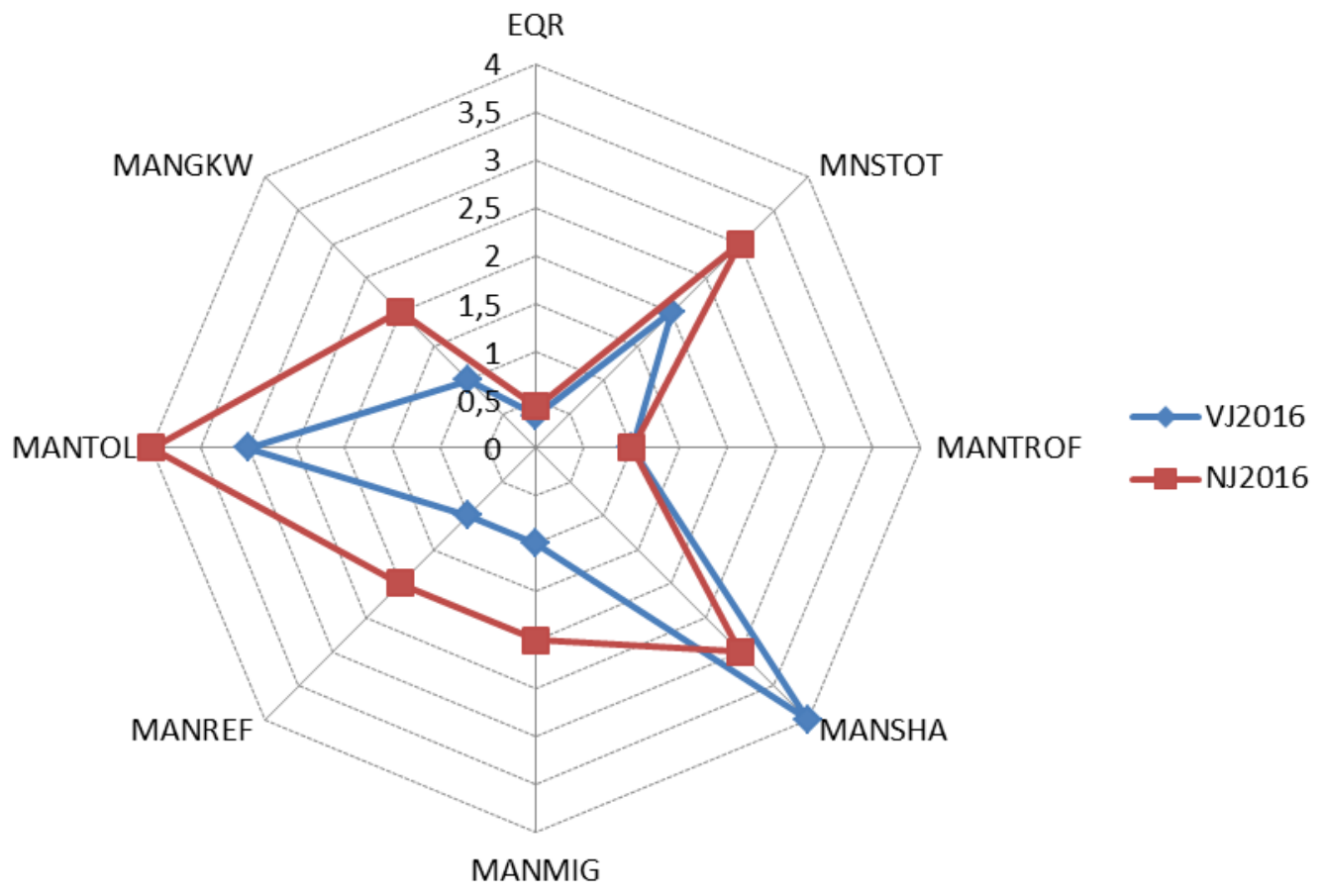

Figuur 26: De EQR en metriekscores voor de Woluwe in het voorjaar en najaar van 2016.

De verklaring van de gebruikte afkortingen staan in Tabel 27.

In het najaar 2016 was de EQR hoger dan in het najaar 2013 maar nog steeds te laag om de "matige" toestand te bereiken. Bermpje en kopvoorn ontbreken nog in de Woluwe, hoewel de habitat vermoedelijk geschikt is. Deze referentie soorten zouden de EQR gunstig beïnvloeden.

Op basis van de combinatie van voor- en najaarvangsten scoort de Woluwe "onvoldoende" (EQR 0,49; Figuur 27). 


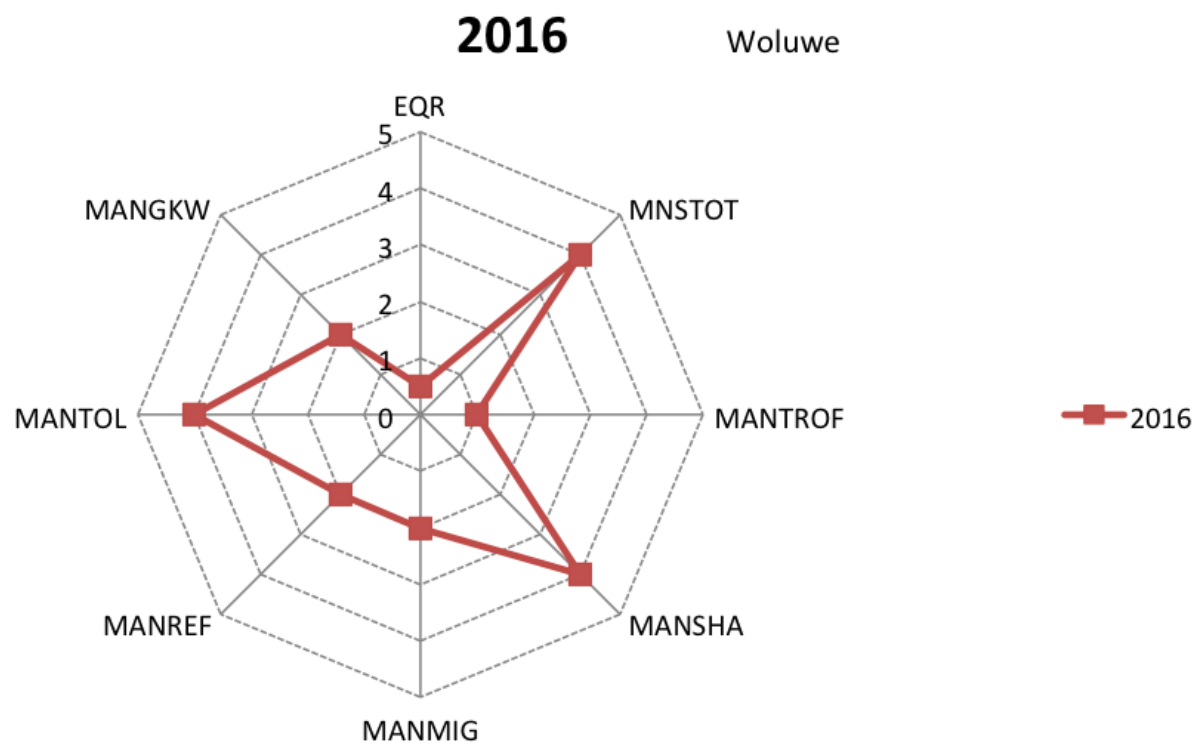

Figuur 27: Globale EQR en metriekscores voor de Woluwe in 2016.

\subsubsection{Roodkloosterbeek}

De EQR waarden voor de Roodkloosterbeek waren in 2004 0,32, in 2007 was dat 0,31 en 0,32 in 2013. De score in 2013 is in feite te hoog gezien toen slechts enkel riviergrondel was gevangen. In het voorjaar van 2016 was de EQR 0,31 terwijl 0,35 in het najaar. De ecologische appreciatie is voor beide campagnes in 2016 "ontoereikend". In 2016 werden er meer individuen en soorten gevangen dan in vorige campagnes. Toch blijft het feit dat de oevers gedeeltelijk verstevigd zijn wat niet ideaal is als habitat voor vissen.

De bijdrage van de verschillende metrieken tot de EQR zijn weergegeven in Figuur 28. 


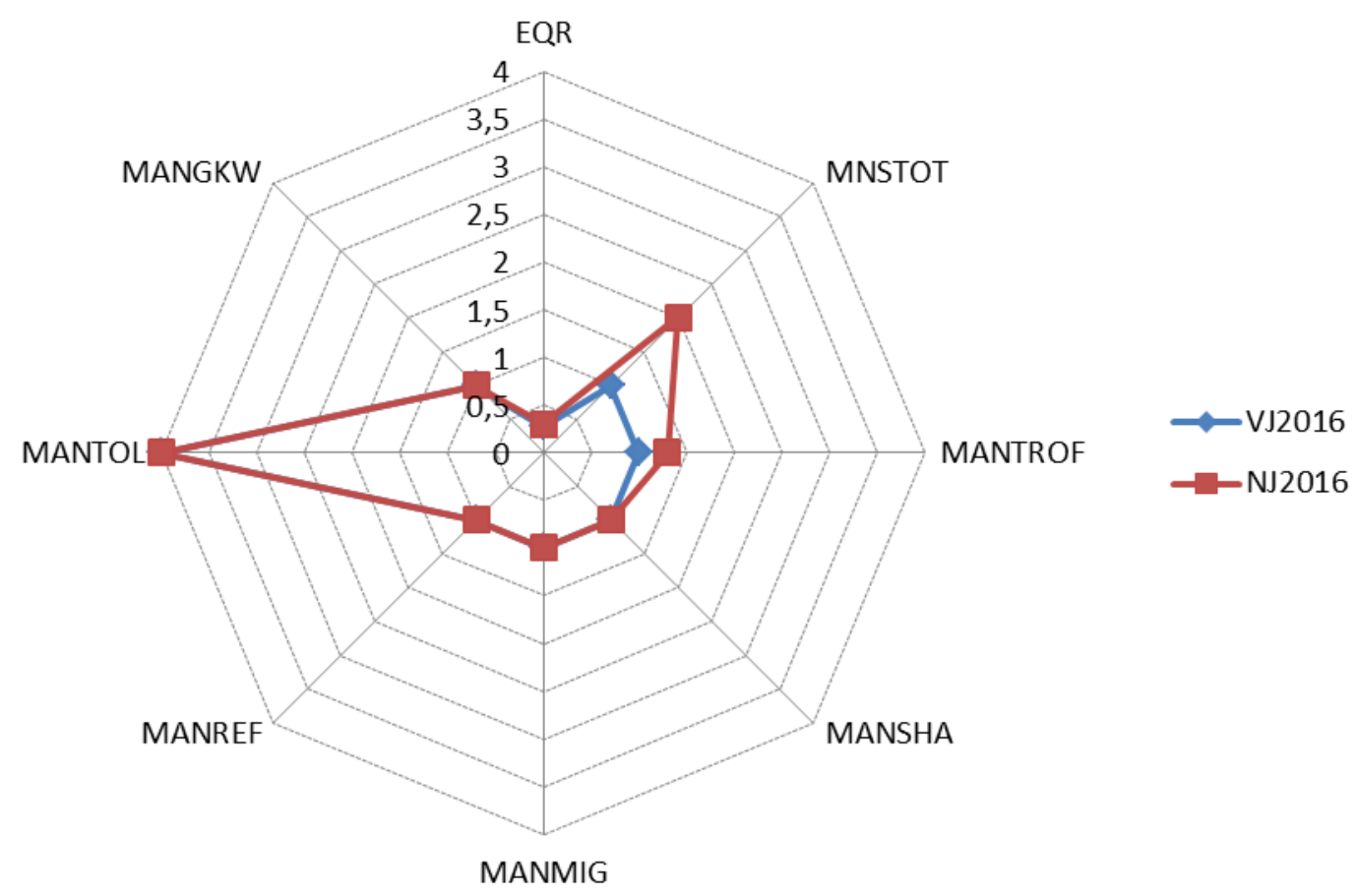

Figuur 28: De EQR en metriekscores voor de Roodkloosterbeek in het voorjaar en najaar van 2016.

De gebruikte afkortingen staan in Tabel 27.

Het aantal soorten blijft laag en piscivoren ontbreken. De aanwezigheid van de exotische bruine Amerikaanse dwergmeerval is een indicatie van verstoring. Riviergrondel domineert in aantal individuen en haalt de evenness naar beneden. Referentie soorten zoals blankvoorn, bermpje en kopvoorn ontbreken. Enkel de metriek "tolerantie waarde" scoort goed.

Op basis van de combinatie van voor- en najaarvangsten scoort de Roodkloosterbeek “onvoldoende" (EQR 0,31; Figuur 29). 


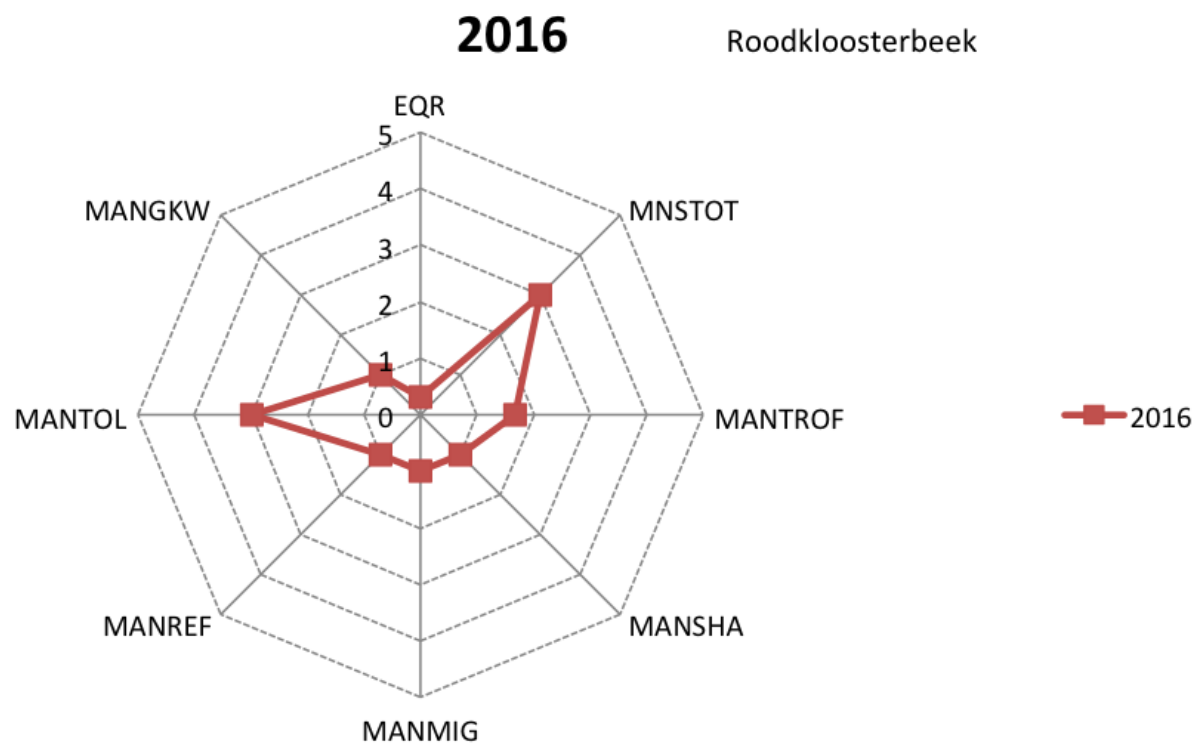

Figuur 29: Globale EQR en metriekscores voor de Roodkloosterbeek in 2016.

\subsubsection{Kanaal Brussel-Charleroi}

Voor het berekenen van de EQR voor kanalen wordt er rekening gehouden met de methode van afvissing. Met de elektrische vangstresultaten worden volgende metriekwaarden berekend: MnsTot: aantal soorten; Man Bio: de biomassa en ManSha: de Shannon Wiener index. Met de fuikvangst resultaten berekenen we ManRek of het aantal soorten dat rekruteert en BenWei het gewichtspercentage van bentische soorten.

Gebruikmakend van de voor- en najaarvangsten op beide locaties werden de metriekwaarden berekend (Tabel 40)

Tabel 40: Overzicht van de metriekwaarden berekend op basis van elektrische en fuikvangsten in het voor- en najaar van de verschillende campagnes in het kanaal Brussel Charleroi.

\begin{tabular}{|c|c|c|c|c|c|}
\hline & MnsTot & ManBio & ManSha & ManRec & BenWei \\
\hline 2004 & 2 & 1.5 & 0.2 & 36.4 & 32.9 \\
\hline 2007 & 5 & 0.7 & 1.0 & 57.1 & 18.5 \\
\hline 2013 & s & 2.8 & 1.2 & 62.5 & 11.1 \\
\hline 2016 & $\varepsilon$ & 1.1 & 1.1 & 54.5 & 18.7 \\
\hline
\end{tabular}

De waarden worden gescoord en daarmee wordt de ERQ berekend (Figuur 30). 


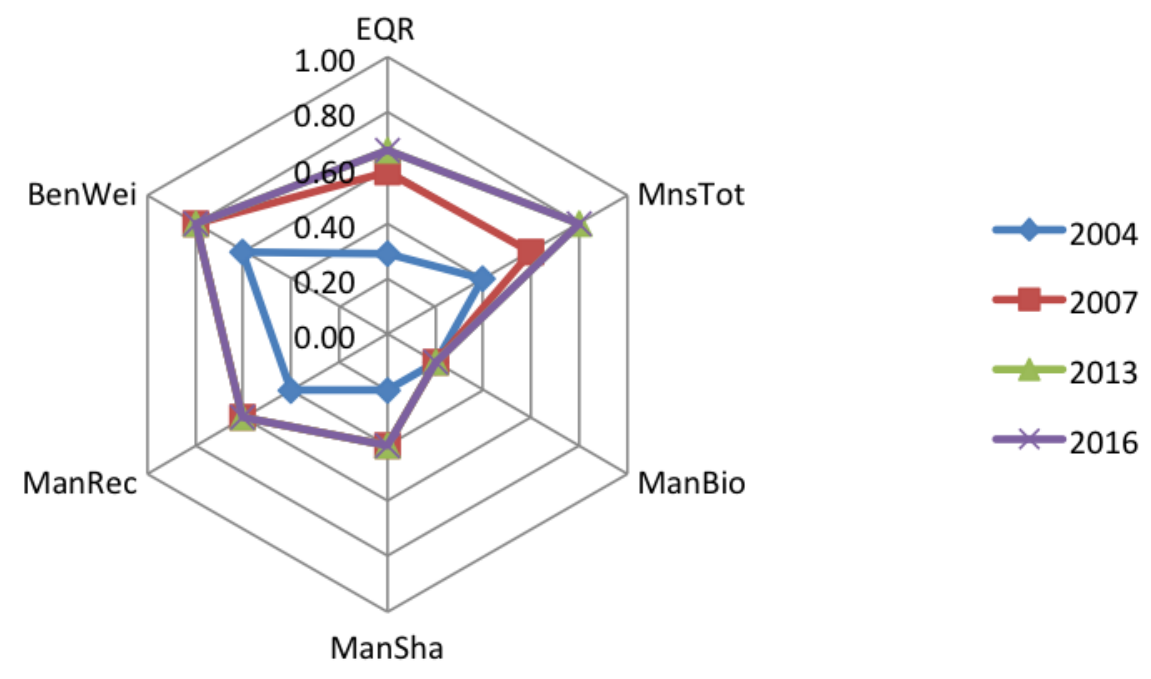

Figuur 30: De EQR en metriekscores voor het Kanaal Brussel Charleroi in 2004, 2007, 2013 en 2016.

In 2004 scoort het kanaal "ontoereikend" (EQR: 0,29). In 2007 scoort het kanaal "matig" met een EQR waarde van 0,58. In 2013 is de ecologische status ook "matig" maar is de EQR gestegen tot 0,66. In 2016 scoort het kanaal met 0,66 opnieuw "matig".

Ter illustratie kan de beoordeling per locatie worden berekend. De nieuwe index is niet echt gemaakt voor deze oefening, maar het toont toch aan dat C1 (kanaal IN) altijd beter scoort dan C2 (kanaal UIT) (Tabel 41).

Tabel 41: Overzicht van de EQR in het voorjaar en najaar 2016 per locatie voor het Kanaal Brussel Charleroi in het Brusselse Gewest.

\begin{tabular}{lcccccccc}
\hline Periode & Locatie & MnsTot & ManBio & ManSha & ManRec & BenWei & EQR & beoordeling \\
\hline Voorjaar 2016 & C1 & 0,6 & 0,2 & 0,6 & 0,6 & 0,8 & 0,53 & matig \\
Voorjaar 2016 & C2 & 0,2 & 0,2 & 0,2 & 0,4 & 0,6 & 0,18 & slecht \\
Najaar 2016 & C1 & 0,4 & 0,2 & 0,4 & 0,4 & 0,2 & 0,18 & slecht \\
Najaar 2016 & C2 & 0,2 & 0,2 & 0,2 & 0,4 & 0,4 & 0,12 & slecht \\
\hline
\end{tabular}

\subsection{Overzicht en evolutie}

Figuur 31 geeft een overzicht van de EQR voor vis in 2016. Voor het kanaal is er qua appreciatie een evolutie van 'ontoereikend in 2004 tot 'matig' in 2007 en 2013. In het voorjaar 2016 scoort locatie C1 'matig' terwijl in alle andere campagnes in 2016 de locaties C1 en C2 'slecht' scoren. De ecologische status van de locatie kanaal IN (C1) blijft beter dan kanaal UIT (C2). De Roodkloosterbeek evolueerde van een 'slechte' toestand in vorige campagnes tot een 'ontoereikende' toestand in 2016. De Woluwe scoorde 'matig' in 2004 terwijl ze 'ontoereikend' scoort in 2007, 2013 en 2016. De Zenne na RWZI Zuid (S2) evolueerde positief en scoort nu 'slecht'. De Zenne (S4, na RWZI, Brussel Noord) blijft nog in een 'slechte' toestand. In beide locaties is de EQR wel gestegen. 


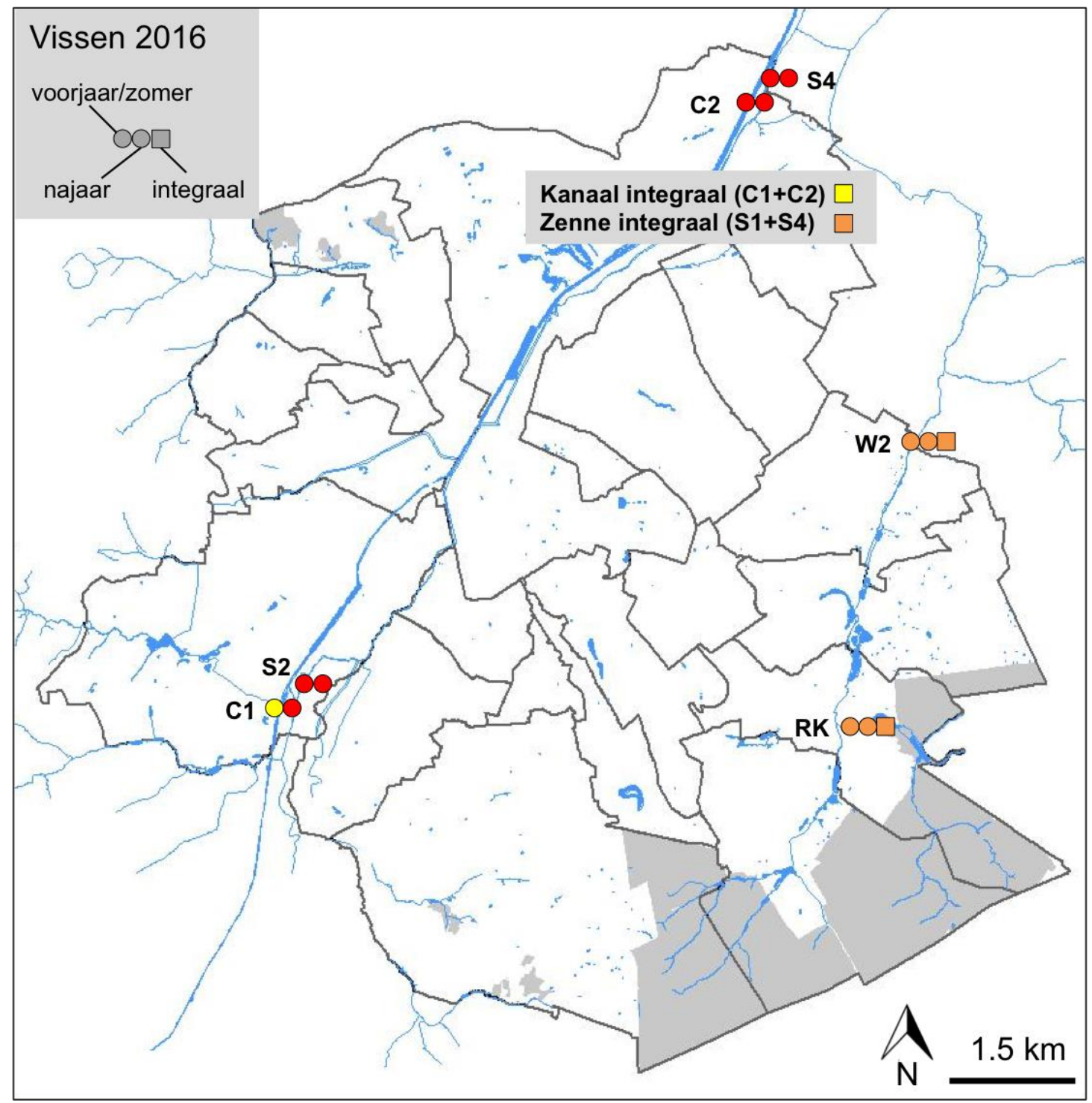

Figuur 31: Ruimtelijk overzicht van de kwaliteit voor het onderdeel vis. 


\section{Ondersteunende (a)biotiek}

\section{Inleiding}

Samen met de biologische kwaliteitselementen worden in de KRW o.a. een aantal milieuvariabelen opgelijst die relevant zijn voor het functioneren van aquatische ecosystemen in of verwant aan meren. Objectieven voor deze ondersteunende variabelen zijn gelijkaardig aan deze voor de biotische gemeenschappen, met het streven naar hooguit kleine deviaties van typespecifieke referentiecondities. De KRW vermeldt saliniteit (conductiviteit), temperatuur, opgeloste zuurstof, aciditeit $(\mathrm{pH})$, transparantie (Secchidiepte), nutriënten en (hydro)morfologische eigenschappen. Van polluenten waarvan vermoed wordt dat ze problematisch zijn, eist de KRW opvolging en kwantificatie van de lozing.

De toegepaste methodologie voor supplementaire variabelen in vijvers en het kanaal streeft naar een in de optiek van de KRW zo volledig mogelijke beoordeling van de ecologische status (Van Onsem \& Triest 2015). De vijvers zijn niet aangemeld bij de Europese Commissie als onderdeel van de KRW-doelstellingen, en monitoring van hun toestand riskeert daarom inhoudelijke hiaten te bevatten wanneer enkel rekening wordt gehouden met de biologische kwaliteitselementen. De in Van Onsem \& Triest (2015) voorgestelde parameters dienen als aanvulling op de resultaten van de klassieke biologische organismegroepen en geven de status van ondersteunende (a)biotiek weer van het aquatische milieu. Het scoringsprincipe is geïnspireerd op ECOFRAME (Moss et al. 2003) en vermijdt dat een beperkt aantal ongunstige variabelen de doorslag geeft in het totale oordeel.

Bij wijze van test wordt in dit rapport ook voor het kanaal de uitkomst van de kwaliteit van supplementaire variabelen uitgewerkt. Omwille van de hydrologische affiniteit van het kanaal met stilstaande waterlichamen (bvb. de mogelijkheid tot ontwikkeling van fytoplankton en zoöplankton) kan de analyse van ondersteunende (a)biotiek nuttige bijkomende informatie opleveren. Eventuele overlap met bestaande operationele of trendmonitoring van fysisch-chemische variabelen in het kanaal dient nagegaan te worden.

\section{Statusbeoordeling}

De argumentatie voor de selectie van ondersteunende variabelen is te vinden in Van Onsem \& Triest (2015) (Tabel 42). Conductiviteit, temperatuur, zuurstof, pH en doorzicht moeten verplicht gemonitord worden in stilstaande waterlichamen die opgevolgd worden in functie van de KRW. TP is een uitstekende proxy voor nutriëntenstatus en vervult in de Brusselse vijvers een grotere indicatieve rol dan inorganische stikstof (Peretyatko et al. 2012). Zoöplankton (Cladocera) vormt een cruciale en relatief eenvoudig te meten component in ondiepe meren en vijvers (Moss et al. 2003; De Backer et al. 2014). Bruikbare grenswaarden binnen de Cladocera-gemeenschap zijn gedocumenteerd voor de Brusselse vijvers (De Backer et al. 2014). Tot slot wordt ook een inschatting gemaakt van de impact van 
eventueel aanwezige invasieve exoten, wat meteen ook integratie mogelijk maakt met de bepalingen van de Europese Verordening omtrent invasieve exoten (EC 2014), die vereist dat monitoring van invasieven zoveel mogelijk wordt geharmoniseerd met KRW- en HRL-monitoring.

Tabel 42: Voorgestelde definitie van kwaliteitsklassen voor negen supplementaire variabelen in kanaal en vijvers. ECOFRAME: Moss et al. 2003; ECOFRAME (adjusted): De Backer 2011. *: categorieën exotische soorten (alle organismegroepen) zijn $0=$ geen exoten aangetroffen, $1=$ exoten aanwezig maar impact beperkt, $2=$ exoten duidelijk invasief en problematisch.

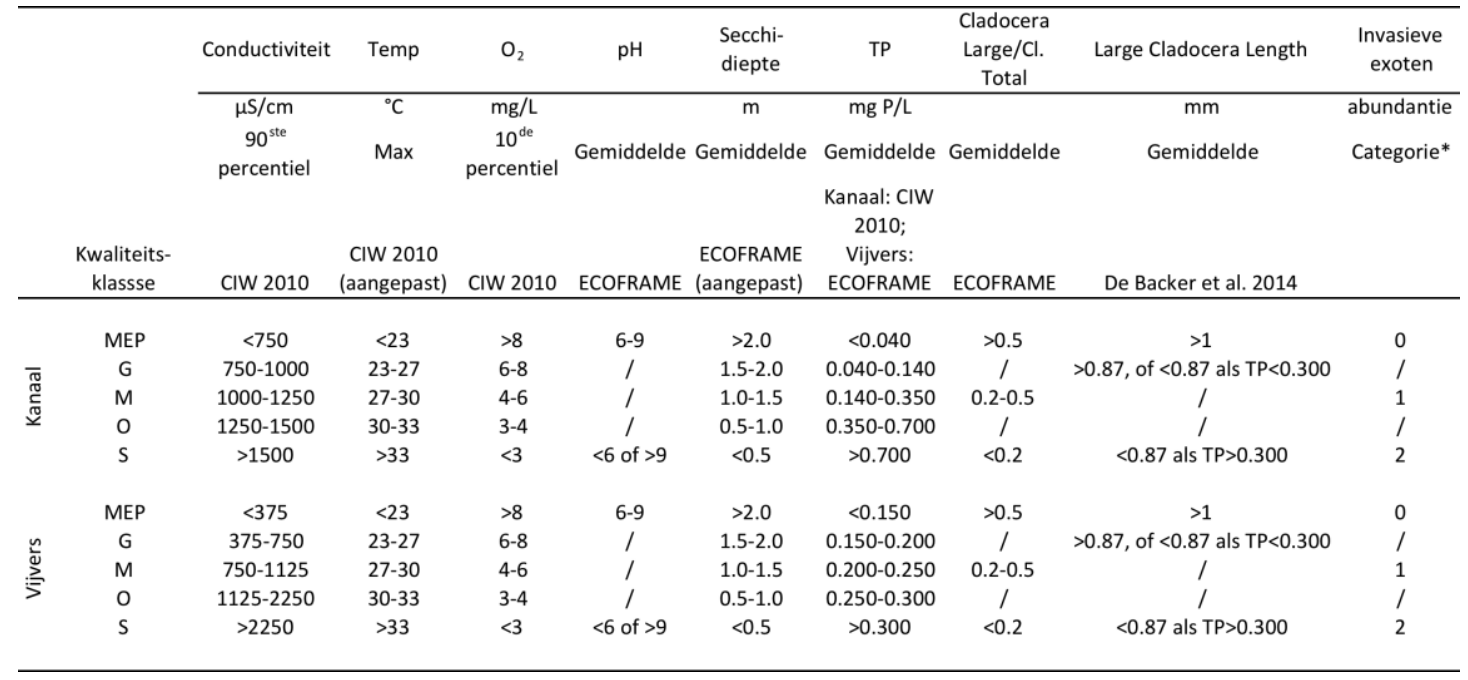

\subsection{Methodologie}

\subsubsection{Fysisch-chemische variabelen}

Conductiviteit, temperatuur, zuurstofconcentratie en $\mathrm{pH}$ werden ter plekke gemeten met elektrodes. Secchidiepte werd bepaald met een Secchischijf met diameter 30 $\mathrm{cm}$. Wanneer de bodem geraakt werd, werd een extra waarde bijgeteld in functie van de zichtbaarheid van de schijf (bvb. $+1.5 \mathrm{~m}$ bij uitstekend doorzicht). TP-waarden werden bepaald op basis van digestie van ongefilterde waterstalen gevolgd door spectrofotometrische analyse van orthofosfaten.

\subsubsection{Zoöplankton}

Zoöplankton werd ingezameld met behulp van een buisvormige plastic sampler en gefixeerd met formaldehyde. Het relatieve aandeel van grote tegenover kleine genera binnen de gemeenschap van watervlooien (Cladocera) werd microscopisch bepaald (Moss et al. 2003). Bij de grote Cladocera werden per genus 20 individuen gemeten. 


\subsubsection{Fysisch-chemische variabelen}

Gemiddelde waarden en kwaliteitsklassen voor de fysisch-chemische variabelen worden gegeven in Tabel 43.

\subsubsection{Zoöplankton}

In het kanaal en $\mathrm{TrBr}$ bleef de proportie grote Cladocera beperkt (Figuur 32). In WPk1 en Wtml was de abundantie van Daphnia gunstiger.

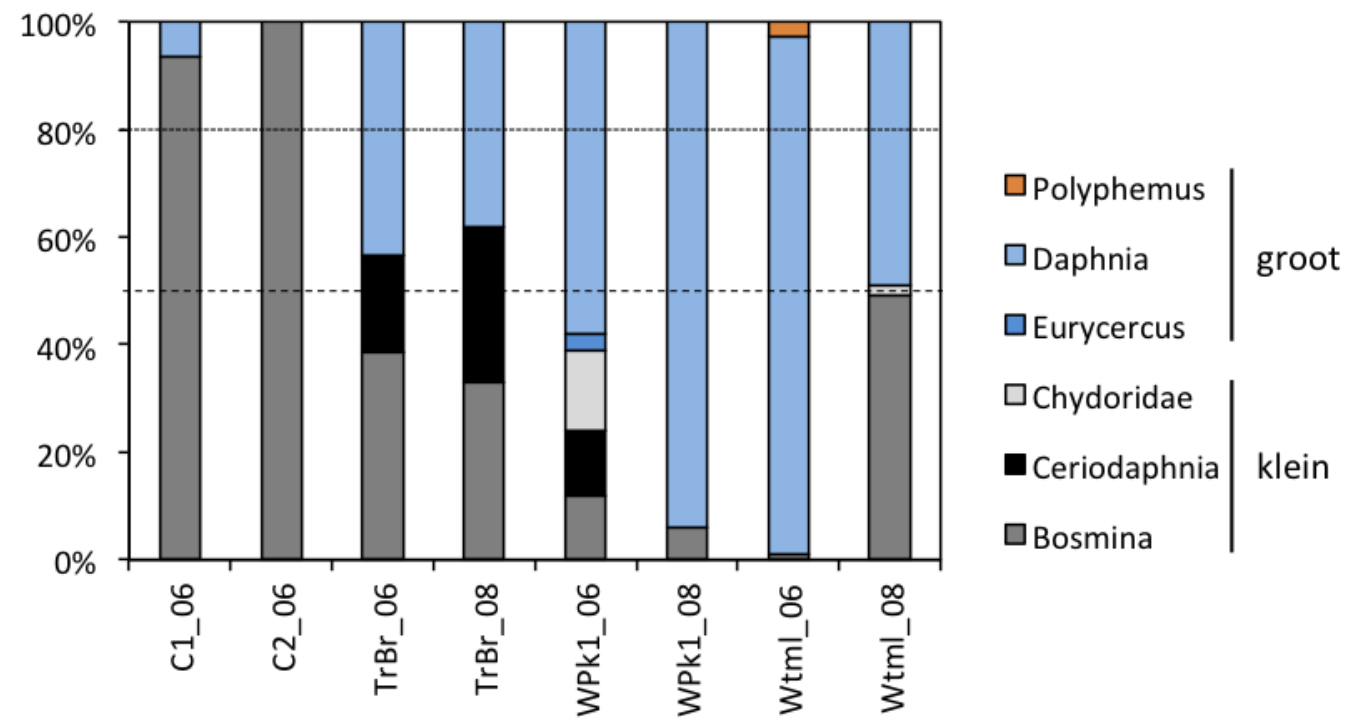

Figuur 32: Relatieve abundantie van watervlooien (Cladocera) in vijvers en het kanaal. Grove stippellijn: grens goede/matige proportie; fijne stippellijn: grens matige/slechte proportie.

\subsubsection{Status}

Tabel 43 geeft een overzicht van de beoordeling op basis van de supplementaire variabelen. C1 en C2 scoren respectievelijk matig en slecht, hoewel de procedure en toegepaste grenswaarden voor het kanaal gevalideerd moeten worden. De kwaliteit van de ondersteunende (a)biotiek in $\mathrm{TrBr}$ bleek onvoldoende, terwijl de ecologische toestand van zowel WPk1 als Wtml weinig gehinderd lijkt door de supplementaire variabelen. 
Tabel 43: Beoordeling van kanaal en vijvers op grond van supplementaire (a)biotiek.

\begin{tabular}{|c|c|c|c|c|c|c|c|c|c|c|c|}
\hline & & Cond. & Temp & $\mathrm{O}_{2}$ & $\mathrm{pH}$ & $\begin{array}{l}\text { Secchi- } \\
\text { diepte }\end{array}$ & TP & $\begin{array}{c}\text { Cladocera } \\
\text { Large/Cl. } \\
\text { Total }\end{array}$ & $\begin{array}{c}\text { Large } \\
\text { Cladocera } \\
\text { Length }\end{array}$ & Invasieven & STATUS \\
\hline Site & Zone & $\begin{array}{c}\mu \mathrm{S} / \mathrm{cm} \\
90^{\text {ste }} \\
\text { percentiel }\end{array}$ & Max & $\begin{array}{c}\mathrm{mg} / \mathrm{L} \\
10^{\mathrm{de}} \\
\text { percentiel }\end{array}$ & Gemiddeld & Gemiddelde & $\begin{array}{c}\mathrm{mg} \mathrm{P} / \mathrm{L} \\
\text { Gemiddelde }\end{array}$ & Gemiddelde & Gemiddelde & $\begin{array}{l}\text { abundantie } \\
\text { Categorie }\end{array}$ & $\begin{array}{c}7 / 9 \\
\text { behorende } \\
\text { tot klasse } \\
\text { of hoger } \\
\end{array}$ \\
\hline $\mathrm{C} 1$ & Oever & 630 & 18.80 & 9.36 & 7.82 & 1.33 & 0.201 & 0.06 & 0.93 & 2 & M \\
\hline $\mathrm{C} 2$ & Oever & 757 & 21.70 & 5.83 & 7.59 & 0.55 & 0.227 & 0.00 & 0.00 & 2 & $P$ \\
\hline $\mathrm{TrBr}$ & Oever & 678 & 19.40 & 5.88 & 7.90 & 0.63 & 0.490 & 0.41 & 0.63 & 1 & $P$ \\
\hline WPk1 & Boot & 789 & 20.90 & 8.18 & 7.66 & 1.99 & 0.043 & 0.78 & 0.89 & 0 & G \\
\hline Wtml & Boot & 538 & 19.50 & 7.62 & 7.99 & 1.45 & 0.077 & 0.74 & 0.82 & 1 & G \\
\hline
\end{tabular}


In het kanaal blijft de voorzichtige verbetering ten opzichte van de eerste reeks staalnamecampagnes behouden (Figuur 33, Figuur 34, Tabel 44, Tabel 45). Uitgezonderd fytoplankton en in afwachting van validatie van het element 'ondersteunende (a)biotiek', werd voor elk onderdeel slechts een matige kwaliteit bereikt.

$\mathrm{Na}$ herrekening van de fytoplanktonwaarden volgens de hernieuwde index haalt vooral C2 een goede toestand doorheen de meeste jaren. Ten opzichte van 2013 vond voor fytoplankton op beide locaties een duidelijke verbetering plaats. Niettemin is de toestand van het kanaal voor dit kwaliteitselement afhankelijk van weersomstandigheden (zoals bewezen door de ontwikkeling van cyanobacteriële bloei in augustus 2015; O. Schmit, pers. comm.), en is het mogelijk dat een verhoogde staalnamefrequentie (binnen het groeiseizoen) een minder rooskleurig beeld oplevert.

Voor macroinvertebraten werd in $\mathrm{C} 2$ een terugval genoteerd vanuit een goede toestand in 2013. Het is mogelijk dat het een natuurlijke fluctuatie betreft langsheen de grens tussen matige en goede kwaliteit, maar ook de toename in de abundantie van Chinese wolhandkrab (Eriocheir sinensis), een invasieve exoot met grote impact op het ecosysteem (IUCN 2009), kan een verklarende factor zijn. De soortenrijkdom van macroinvertebraten nam af ten opzichte van 2013, o.a. door afwezigheid van enkele taxa binnen de Mollusca (Van Onsem et al. 2014), een voor omnivore decapoden preferentiële prooidiergroep.

In de visgemeenschap vindt een ongunstige toename plaats van de eveneens invasieve Zwartbekgrondel. Nader onderzoek is vereist om uitsluitsel te bieden omtrent de potentiële impact van invasieve exoten op het bereiken van het globale GEP in het kanaal. Voorlopig lijken ook de waterkwaliteit en constante sedimentresuspensie (cf. matige resultaten voor fytobenthos) belangrijke knelpunten.

Statistische analyse van de trend sinds 2004 toont geen significante evolutie (R3.2.0 en Statistica 8; $n=8 /$ jaar; MANOVA Wilks $\lambda=$ n.s.; Figuur 35). Er blijkt geen verschil te zijn tussen de jaren waarin alle relevante biologische kwaliteitselementen werden bemonsterd (dus exclusief 2009-2010). Verschillen tussen C1 en C2 zijn eveneens niet significant (General Linear Model, site als fixed factor, jaar als within-subject repeated measures factor). Voor visdata werd in de analyses echter de afzonderlijk berekende EQR gebruikt, die voor het kanaal in 2016 duidelijk lager lagen dan de totale, gecombineerde EQR. 


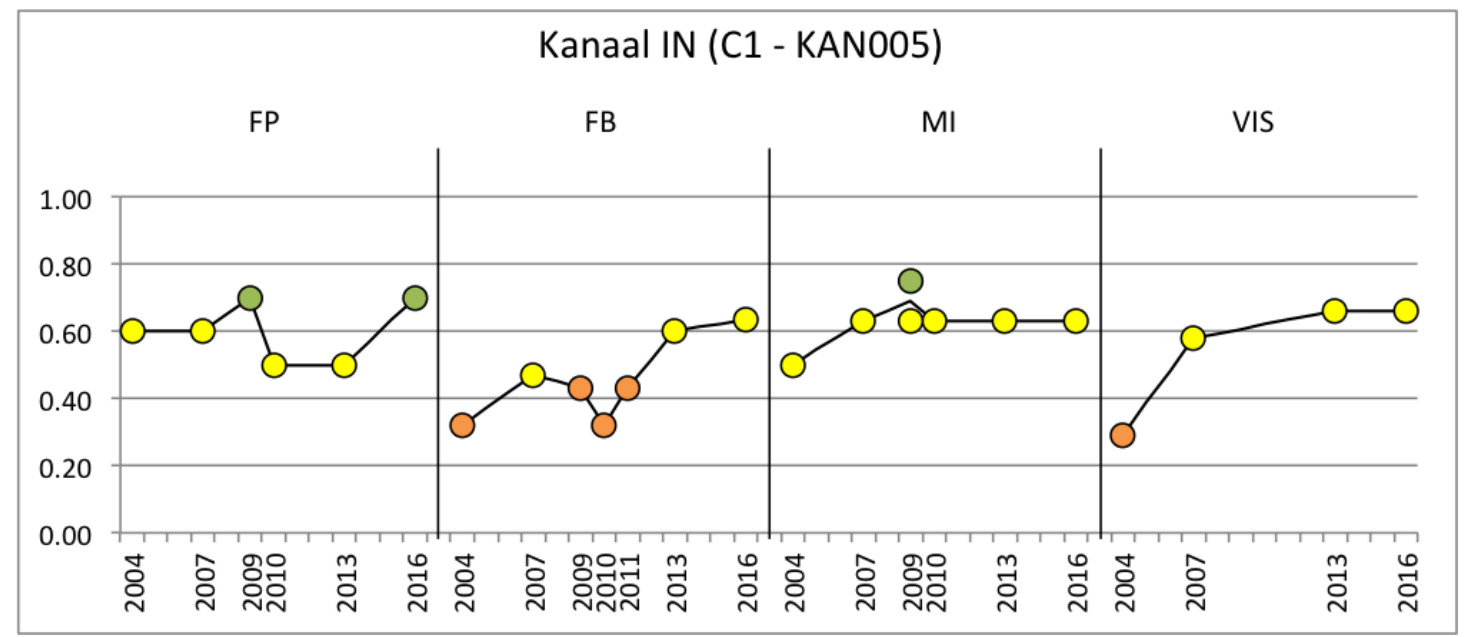

Figuur 33: Temporele evolutie van EQR in C1.

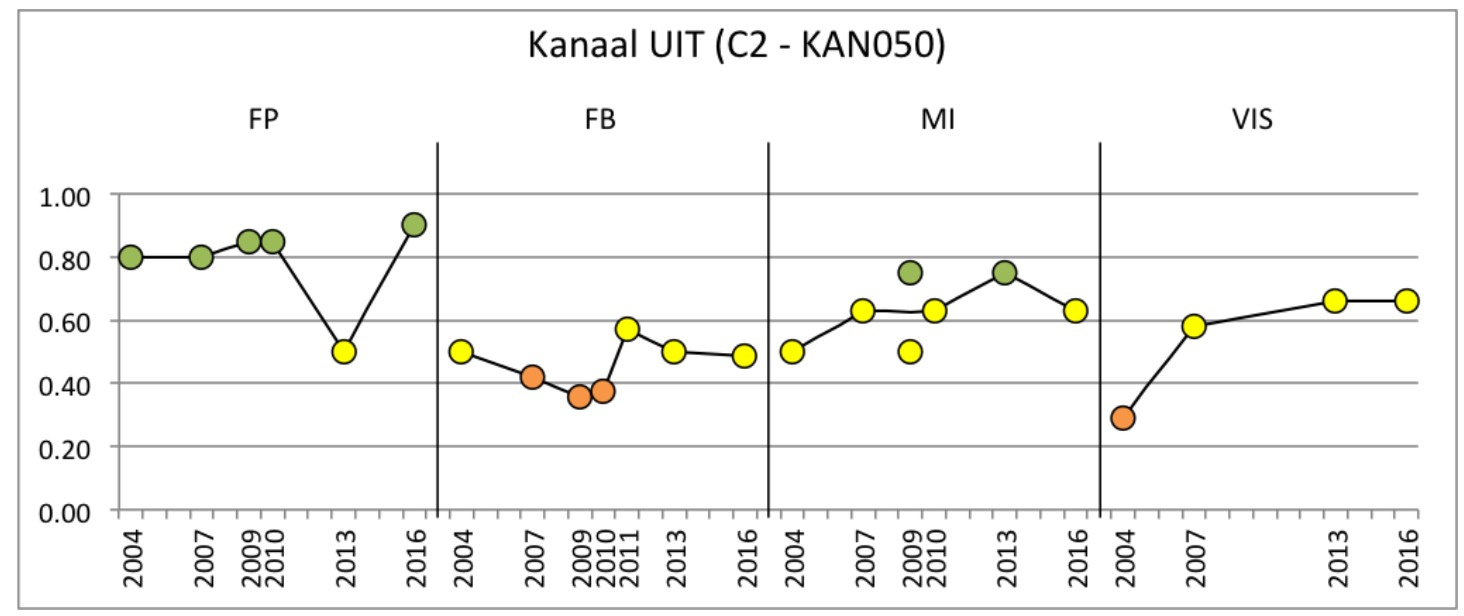

Figuur 34: Temporele evolutie van EQR in C2.

Tabel 44: Temporele evolutie van EQR in C1. *: de EQR-waarde voor vis in het kanaal wordt berekend o.b.v. combinatie van beide staalnamepunten.

\begin{tabular}{lccccccc}
\hline C1 - KAN005 & 2004 & 2007 & 2009 & 2010 & 2013 & 2016 \\
\cline { 2 - 8 } & & & & & & \\
FP & 0.60 & 0.60 & 0.70 & 0.50 & 0.50 & 0.70 \\
FB & 0.32 & 0.47 & 0.43 & 0.32 & 0.60 & 0.64 \\
MF & nvt & nvt & nvt & nvt & nvt & nvt \\
MI & 0.50 & 0.63 & 0.75 & 0.63 & 0.63 & 0.63 & 0.63 \\
VIS & $0.29 *$ & $0.58^{*}$ & nvt & nvt & $0.66^{*}$ & $0.66^{*}$ \\
GLOBAAL (OoAo) & 0 & $\mathrm{M}$ & 0 & 0 & $\mathrm{M}$ & $\mathrm{M}$ \\
\hline
\end{tabular}


Tabel 45: Temporele evolutie van EQR in C2. *: de EQR-waarde voor vis in het kanaal wordt berekend o.b.v. combinatie van beide staalnamepunten.

\begin{tabular}{l|ccccccc}
\hline C2 - KAN050 & 2004 & 2007 & 2009 & 2010 & 2013 & 2016 \\
\cline { 2 - 8 } & & & & & & \\
FP & 0.80 & 0.80 & 0.85 & 0.85 & 0.50 & 0.90 \\
FB & 0.50 & 0.42 & 0.36 & 0.38 & 0.50 & 0.49 \\
MF & nvt & nvt & nvt & nvt & nvt & nvt \\
MI & 0.50 & 0.63 & 0.75 & 0.50 & 0.63 & 0.75 & 0.63 \\
VIS & $0.29^{*}$ & $0.58^{*}$ & nvt & nvt & $0.66^{*}$ & $0.66^{*}$ \\
& & & & & & \\
GLOBAAL (OoAo) & 0 & 0 & 0 & 0 & M & M \\
\hline
\end{tabular}

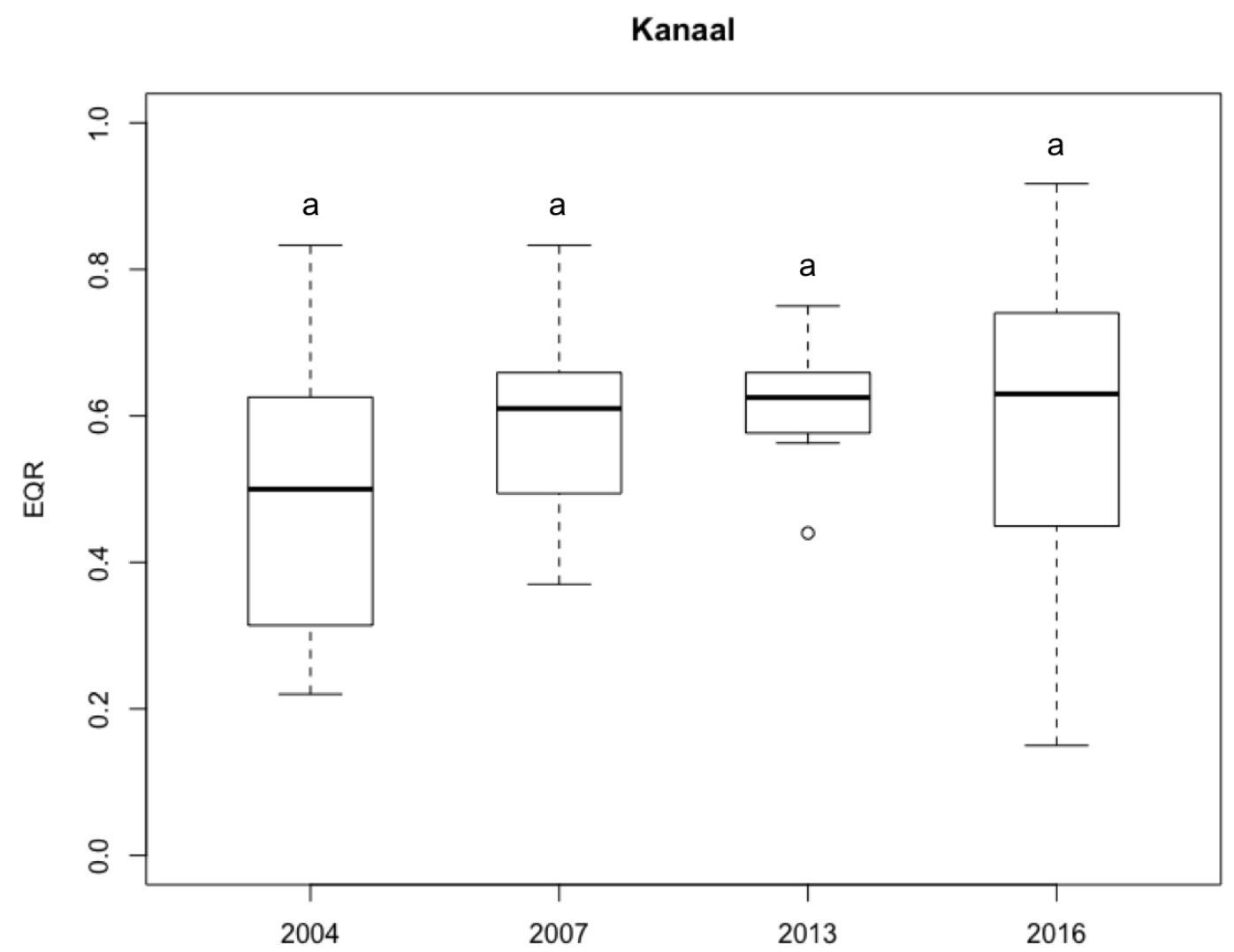

Figuur 35: Temporele evolutie voor kanaal ( $n=8$ per jaar, EQR getransformeerd volgens klassengrenzen 0-0.25-0.50-0.75-1). Eenzelfde letter boven de boxplots duidt gelijkenis aan, verschillende letters duiden verschil aan.

\subsection{Zenne}

De algemene ecologische status van de Zenne blijft ver verwijderd van de door de KRW en het Waterbeheerplan geformuleerde doelstellingen (Figuur 36, Figuur 37, Figuur 38, Tabel 46, Tabel 47, Tabel 48). Een spectaculaire positieve tendens sinds 
het in werking treden van de RWZI's Noord en Zuid is de terugkeer van vis, zowel stroomopwaarts als stroomafwaarts het overdekte gedeelte van de Zenne. In 2016 werd voor de eerste keer sinds de start van de monitoring vis aangetroffen in het zuidelijk deel van het Brussels Hoofdstedelijk Gewest, met een verbetering van de kwaliteit voor dit element van 'doods' naar ontoereikend.

Terwijl in 2013 slechts één enkele Giebel werd gevangen in S4, was de visgemeenschap duidelijk diverser en rijker in 2016. Onder de huidige omstandigheden is een verbetering tot GEP voor vis nog niet realistisch.

Een bijkomende gunstige trend in de Zenne is de klasseverbetering in de EQR voor fytobenthos gaande van ontoereikend in 2013 naar matig in 2016. Het is onduidelijk of dit een gevolg is van bvb. een verdunningseffect (zware regenval in het late voorjaar) of - parallel aan de terugkeer van visleven - een signaal van structureel herstel.

Op beide locaties verlaagde de EQR-score voor macrofyten, door afwezigheid van submerse vegetatie aan S1 (mogelijk a.g.v. baggerwerkzaamheden) en licht verminderde abundantie van Schedefonteinkruid aan S4. Bij de noordgrens van het gewest verlaagde de kwaliteit op vlak van macroinvertebraten, resulterend in een globale slechte ecologische kwaliteit. De invertebratengemeenschap blijft gedomineerd door taxa met een hoge tolerantie voor hypoxische of anoxische omstandigheden.

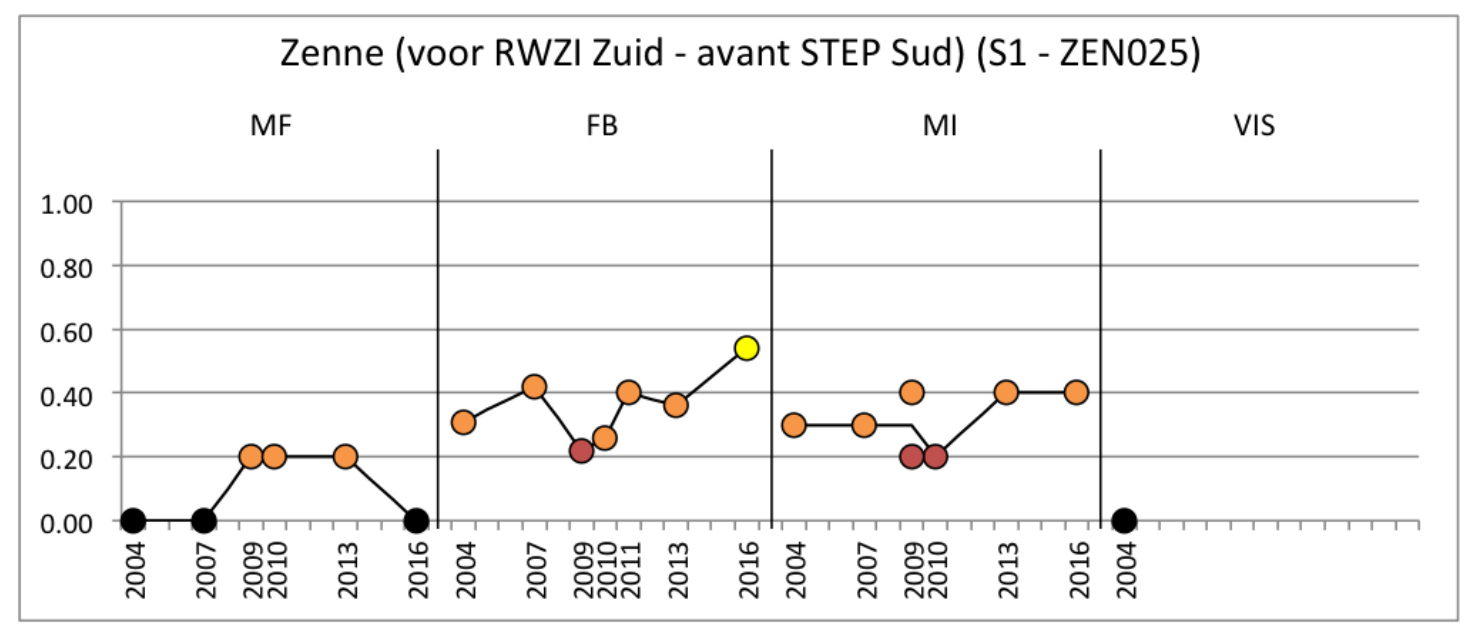

Figuur 36: Temporele evolutie van EQR in S1. 


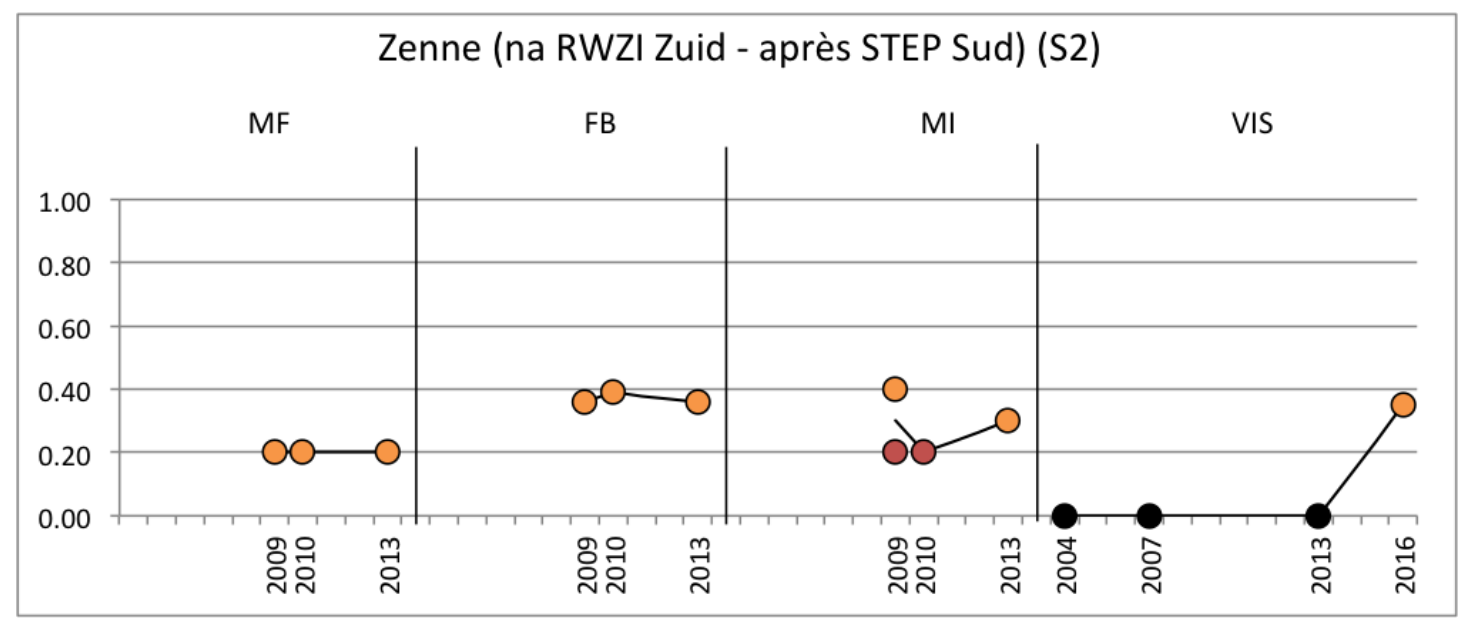

Figuur 37: Temporele evolutie van EQR in S2.

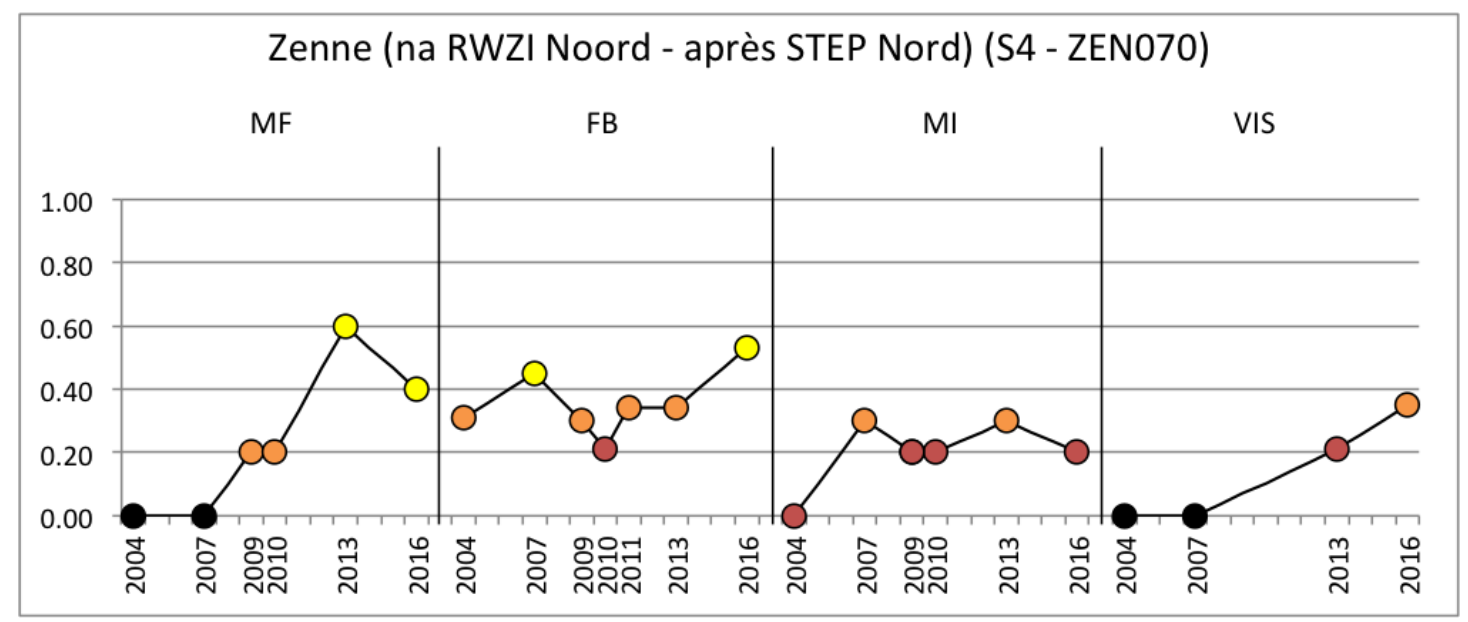

Figuur 38: Temporele evolutie van EQR in S4.

Tabel 46: Temporele evolutie van EQR in S1.

\begin{tabular}{|c|c|c|c|c|c|c|}
\hline S1 - ZEN025 & 2004 & 2007 & 2009 & 2010 & 2013 & 2016 \\
\hline FP & nvt & nvt & nvt & nvt & nvt & nvt \\
\hline FB & 0.31 & 0.42 & 0.22 & 0.26 & 0.36 & 0.54 \\
\hline MF & 0.00 & 0.00 & 0.20 & 0.20 & 0.20 & 0.00 \\
\hline MI & 0.30 & 0.30 & $0.20 \quad 0.40$ & 0.20 & 0.40 & 0.40 \\
\hline VIS & 0.00 & nvt & nvt & nvt & nvt & nvt \\
\hline GLOBAAL (OoAo) & $S$ & $S$ & $S$ & $S$ & 0 & S \\
\hline
\end{tabular}


Tabel 47: Temporele evolutie van EQR in S2. *: de EQR-waarde voor vis in de Zenne wordt berekend o.b.v. combinatie van beide staalnamepunten.

\begin{tabular}{|c|c|c|c|c|c|c|}
\hline S2 & 2004 & 2007 & 2009 & 2010 & 2013 & 2016 \\
\hline FP & nvt & nvt & nvt & nvt & nvt & nvt \\
\hline FB & nvt & nvt & 0.36 & 0.39 & 0.36 & nvt \\
\hline MF & nvt & nvt & 0.20 & 0.20 & 0.20 & nvt \\
\hline $\mathrm{Ml}$ & nvt & nvt & $0.40 \quad 0.20$ & 0.20 & 0.30 & nvt \\
\hline VIS & 0.00 & 0.00 & nvt & nvt & 0.00 & $0.35^{*}$ \\
\hline GLOBAAL (OoAo) & $\mathrm{S}$ & $\mathrm{S}$ & $S$ & $S$ & $S$ & 0 \\
\hline
\end{tabular}

Tabel 48: Temporele evolutie van EQR in S4. *: de EQR-waarde voor vis in de Zenne wordt berekend o.b.v. combinatie van beide staalnamepunten.

\begin{tabular}{lccccccc}
\hline S4 - ZEN070 & 2004 & 2007 & 2009 & 2010 & 2013 & 2016 \\
\cline { 2 - 8 } & & & & & & \\
FP & nvt & nvt & nvt & nvt & nvt & nvt \\
FB & 0.31 & 0.45 & 0.30 & 0.21 & 0.34 & 0.53 \\
MF & 0.00 & 0.00 & 0.20 & 0.20 & 0.60 & 0.40 \\
MI & 0.00 & 0.30 & 0.20 & 0.20 & 0.20 & 0.30 & 0.20 \\
VIS & 0.00 & 0.00 & nvt & nvt & 0.21 & $0.35^{*}$ \\
& & & & & & & \\
GLOBAAL (OoAo) & $\mathrm{S}$ & $\mathrm{S}$ & $\mathrm{S}$ & $\mathrm{S}$ & $\mathrm{S}$ & $\mathrm{S}$ \\
\hline
\end{tabular}

Statistische analyse van de trend in de Zenne toont een significante positieve evolutie sinds 2004 (R3.2.0 en Statistica 8; $n=8 /$ jaar; MANOVA Wilks $\lambda=$ sign.; Figuur 39). Data gebruikt in de MANOVA (analyse van jaarverschillen) en General Linear Model (voor analyse van het effect van site in functie van jaar) werden op voorhand gerankt volgens de 'Aligned Rank Transform (ART)'-methode (ARTool; Wobbrock et al. 2011) omwille van het niet voldaan zijn van assumpties. De EQR-waarden berekend in 2004 verschillen significant van de waarden voor 2016 (gepaarde t-test, Bonferroni-correctie; $p=0.0012<0.0083)$. Er bleek geen verschil tussen locaties S1 (met visdata van S2) en S4. 


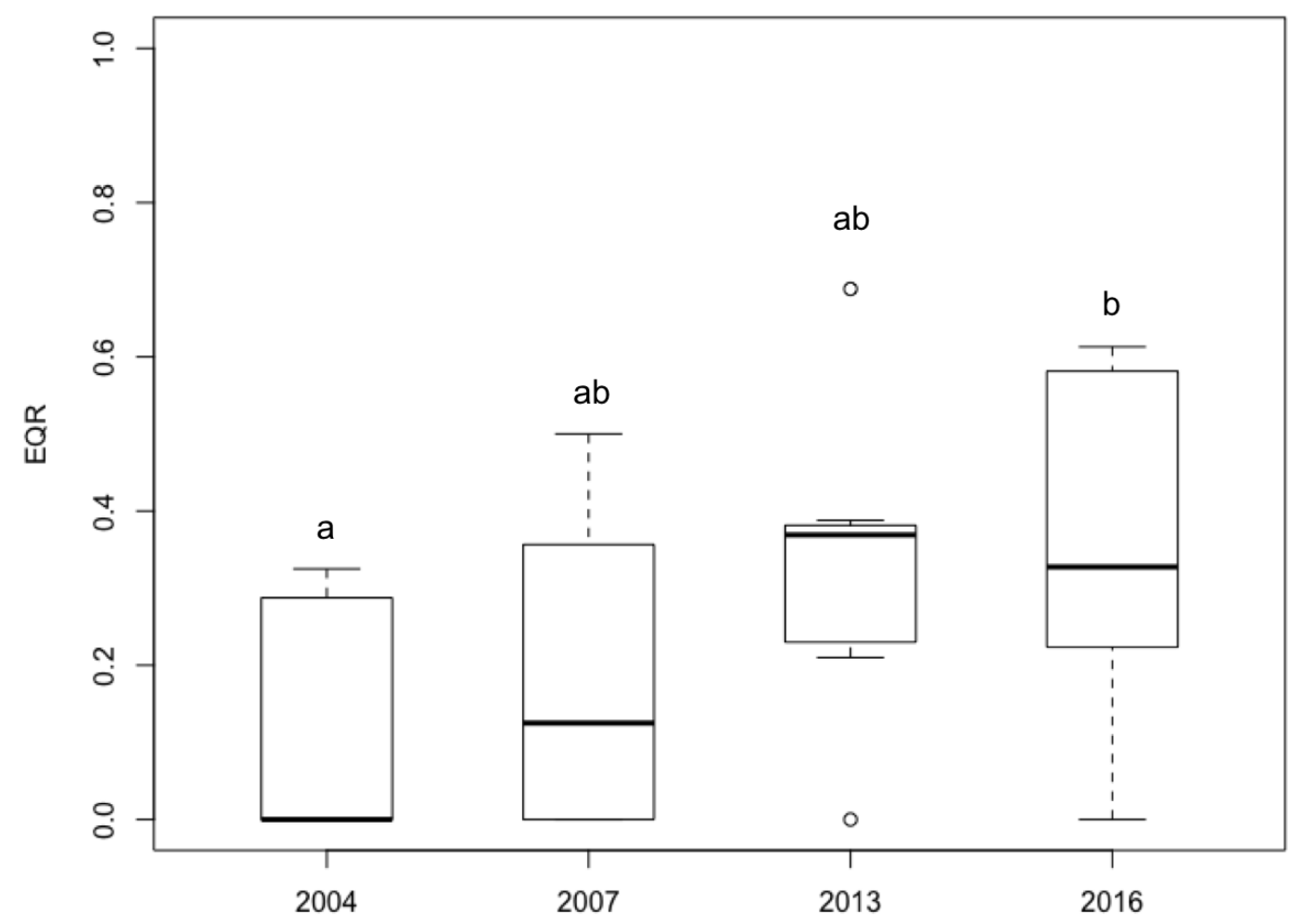

Figuur 39: Temporele evolutie voor Zenne ( $n=8$ per jaar, EQR getransformeerd volgens klassengrenzen 0-0.25-0.50-0.75-1). Eenzelfde letter boven de boxplots duidt gelijkenis aan, verschillende letters duiden verschil aan.

\subsection{Roodkloosterbeek en Woluwe}

\subsubsection{Roodkloosterbeek}

Analyse van waterkwaliteit, fytobenthos en macroinvertebraten geeft een positief beeld van de Roodkloosterbeek (Figuur 40, Tabel 49). Voor macroinvertebraten vond een verbetering plaats ten opzichte van 2013. Een toename van de algemene status wordt nog steeds belemmerd door ongunstige omstandigheden voor plantengroei en vis, door een combinatie van de hydromorfologische structuur en sterke beschaduwing, mogelijk verergerd door de aanwezigheid van Gevlekte rivierkreeften (Orconectes limosus), die schade kunnen veroorzaken aan macrofyten (Van der Wal et al. 2013; Carreira et al. 2014).

De verbeterde EQR voor macrofyten duidt niet meteen een evolutie aan naar een goede toestand voor aquatische vegetatie, aangezien submerse soorten afwezig blijven en rekrutering en vestiging zonder herstructurerende maatregelen (hermeandering of oeveraanpassingen) weinig waarschijnlijk is. 


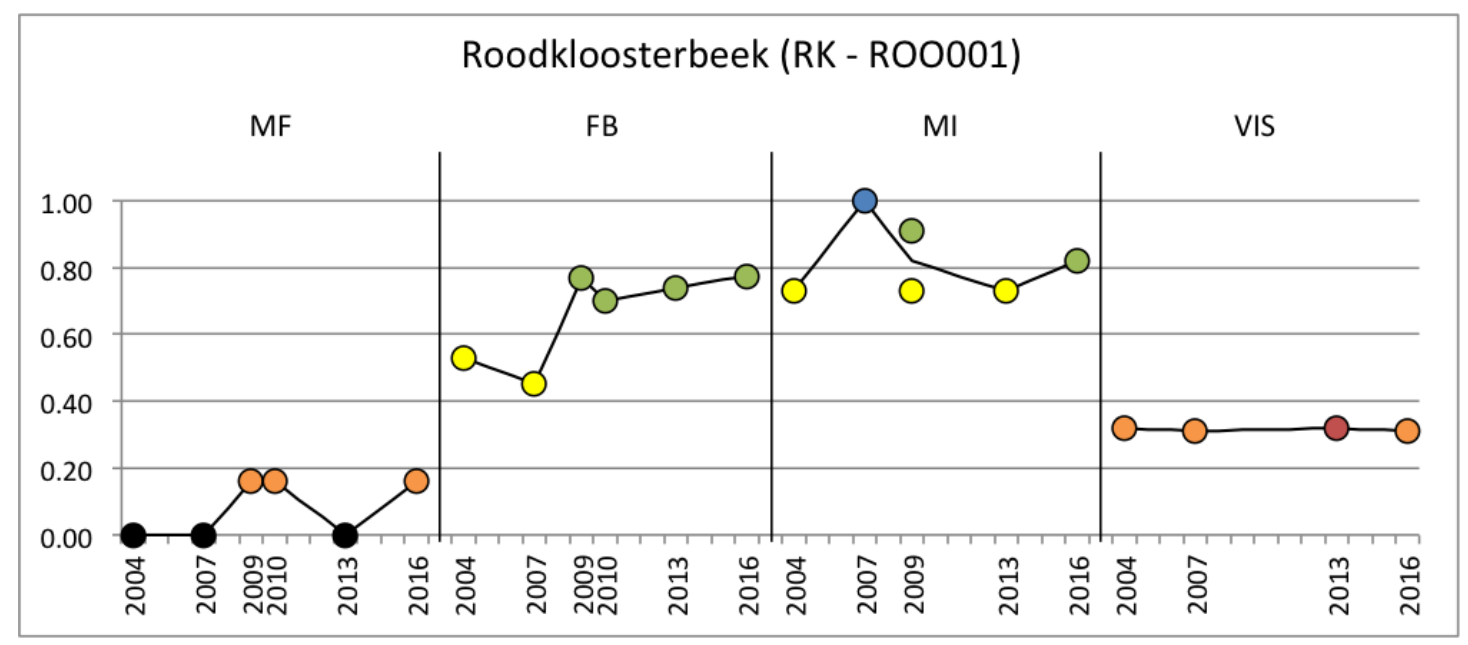

Figuur 40: Temporele evolutie van EQR in RK.

Tabel 49: Temporele evolutie van EQR in RK.

\begin{tabular}{lccccccc}
\hline RK - ROO001 & 2004 & 2007 & 2009 & 2010 & 2013 & 2016 \\
\cline { 2 - 7 } & & & & & & \\
FP & nvt & nvt & nvt & nvt & nvt & nvt \\
FB & 0.53 & 0.45 & 0.77 & 0.70 & 0.74 & 0.78 \\
MF & 0.00 & 0.00 & 0.16 & 0.16 & 0.00 & 0.16 \\
MI & 0.73 & 1.00 & 0.91 & 0.73 & nvt & 0.73 & 0.82 \\
VIS & 0.32 & 0.31 & nvt & nvt & 0.32 & 0.31 \\
& & & & & & \\
GLOBAAL (OoAo) & $\mathrm{S}$ & $\mathrm{S}$ & $\mathrm{O}$ & $\mathrm{O}$ & $\mathrm{S}$ & $\mathrm{O}$ \\
\hline
\end{tabular}

$\mathrm{Er}$ is geen significante evolutie waarneembaar in de Roodkloosterbeek sinds 2004 (R3.2.0 en Statistica 8; $n=4 /$ jaar; Repeated-measures ANOVA; Figuur 41). Data voor 2009-2010 werden echter niet gebruikt omwille van het ontbreken van visgegevens. 


\section{Roodkloosterbeek}

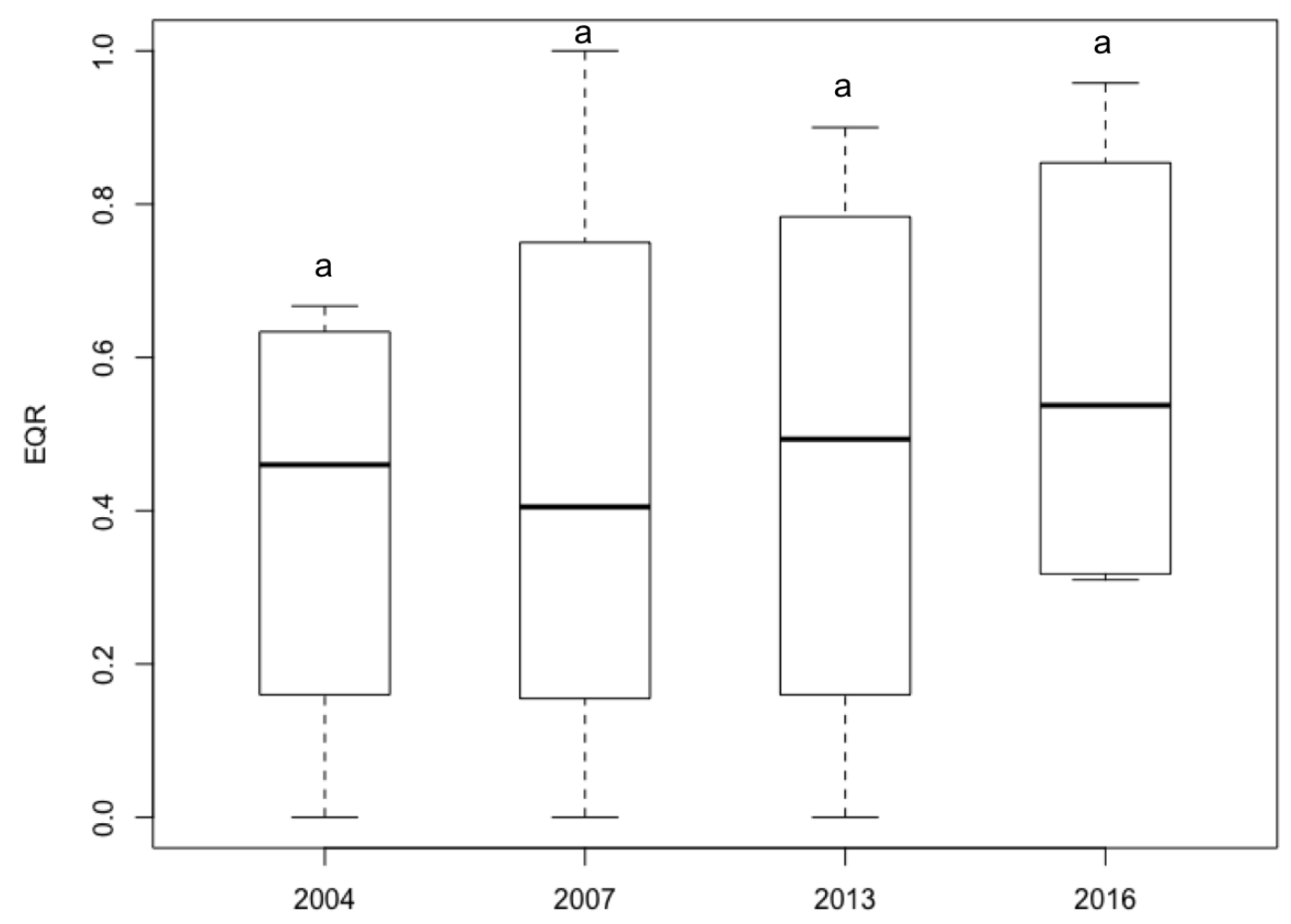

Figuur 41: Temporele evolutie voor Roodkloosterbeek ( $n=4$ per jaar, EQR getransformeerd volgens klassengrenzen 0-0.25-0.50-0.75-1). Eenzelfde letter boven de boxplots duidt gelijkenis aan, verschillende letters duiden verschil aan.

\subsubsection{Woluwe}

De Woluwe kent een gedeeltelijke ecologische terugval sinds 2013 (Figuur 42, Tabel 50). Na een afname van de EQR voor macroinvertebraten trad er in 2016 ook voor fytobenthos een klasseverlaging op. Zonder incorporatie van visdata resulteert dit in een matige algemene toestand en een ongunstig evoluerende afwijking ten opzichte van het GEP. Binnen de macrofytengemeenschap werd in 2016 een lagere abundantie van submerse soorten aangetroffen, alhoewel dit niet wordt gereflecteerd in de EQR.

Een mogelijke verklaring voor de waargenomen wijzigingen vergeleken met 2013 is het verhoogde debiet a.g.v. hevige regenval vroeg in het groeiseizoen en daarmee eventueel gepaard gaande incidentele overstort van afvalwater. Niettemin leek de bedding van de Woluwe aan Hof ter Musschen te kampen met een verhoogde slibdepositie, en zou de gedeeltelijke achteruitgang ook een meer structurele, en dus zorgwekkende, oorzaak kunnen hebben.

De globale kwaliteit van de Woluwe bleef in 2016 ontoereikend a.g.v. het ontbreken van een aantal typespecifieke vissoorten. 


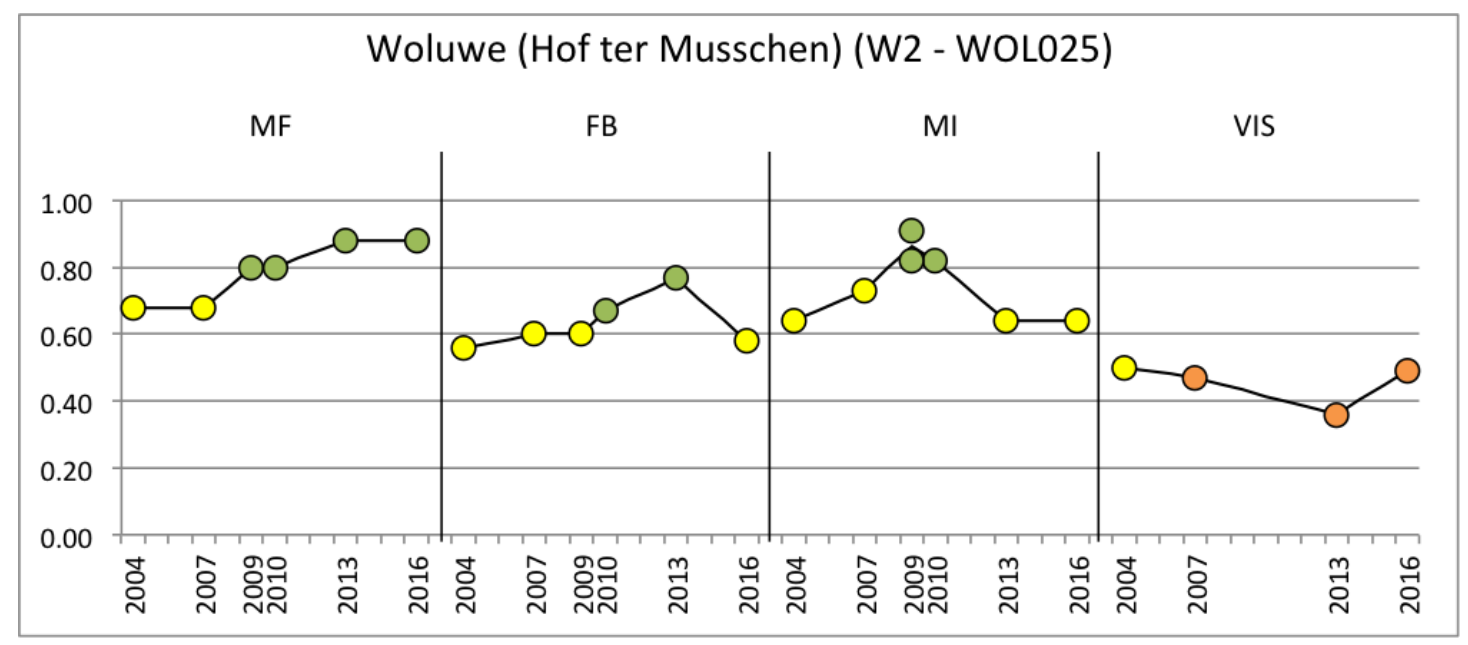

Figuur 42: Temporele evolutie van EQR in W2.

Tabel 50: Temporele evolutie van EQR in W2. *: combinatie voor- en najaarafvissing.

\begin{tabular}{|c|c|c|c|c|c|c|}
\hline W2 - WOL025 & 2004 & 2007 & 2009 & 2010 & 2013 & 2016 \\
\hline FP & nvt & nvt & nvt & nvt & nvt & nvt \\
\hline FB & 0.56 & 0.60 & 0.60 & 0.67 & 0.77 & 0.58 \\
\hline MF & 0.68 & 0.68 & 0.80 & 0.80 & 0.88 & 0.88 \\
\hline $\mathrm{Ml}$ & 0.64 & 0.73 & $0.82 \quad 0.91$ & 0.82 & 0.64 & 0.64 \\
\hline VIS & 0.50 & 0.47 & nvt & nvt & 0.36 & $0.49 *$ \\
\hline GLOBAAL (OoAo) & $M$ & 0 & $M$ & GEP & $\mathrm{O}$ & 0 \\
\hline
\end{tabular}

$\mathrm{Er}$ is geen significante evolutie waarneembaar in de Woluwe sinds 2004 (R3.2.0 en

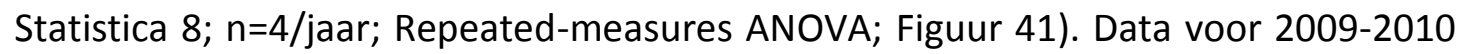
werden echter niet gebruikt omwille van het ontbreken van visgegevens, terwijl er zich een potentiële verslechtering heeft voorgedaan t.o.v. deze periode. 


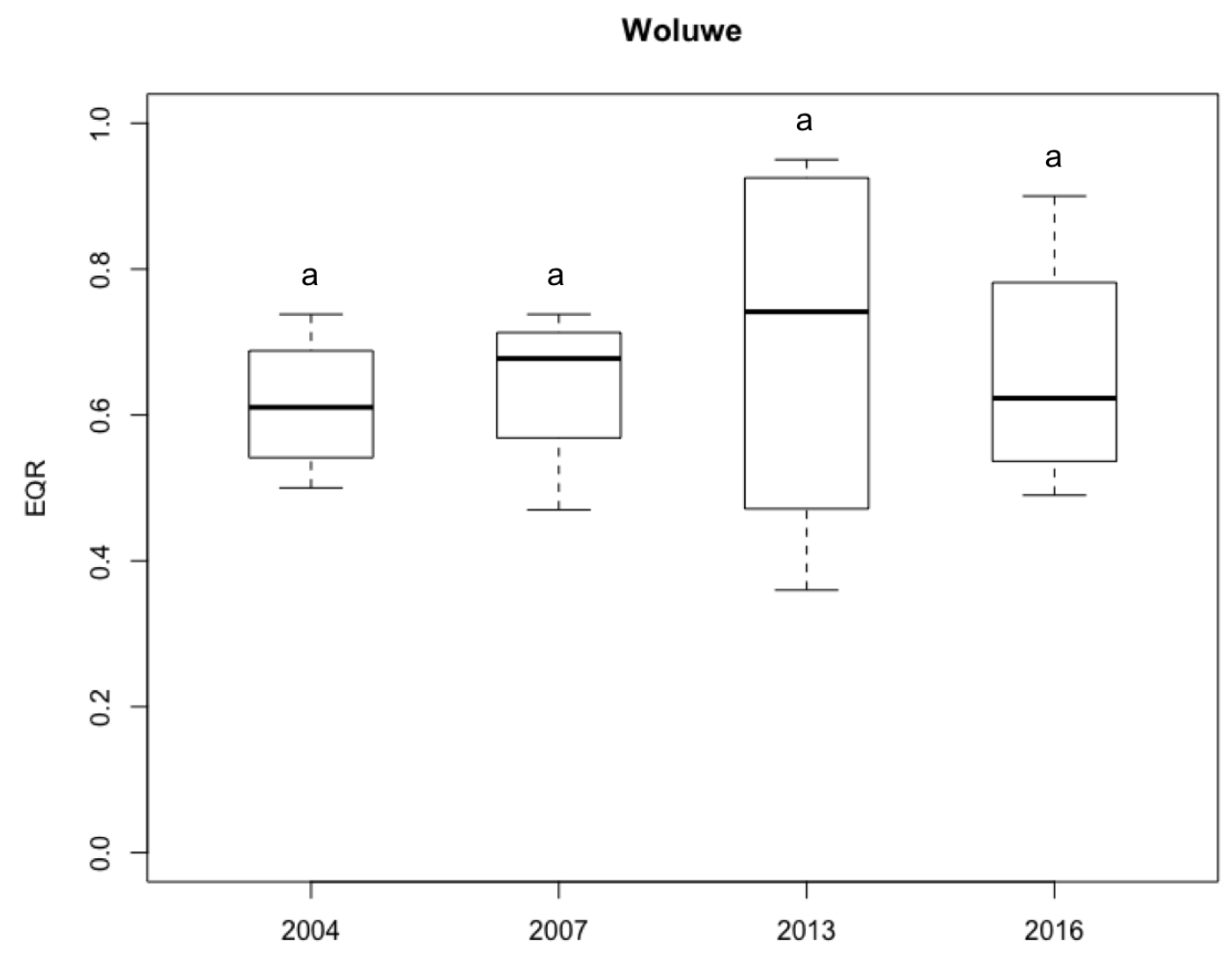

Figuur 43: Temporele evolutie voor Woluwe ( $n=4$ per jaar, EQR getransformeerd volgens klassengrenzen 0-0.25-0.50-0.75-1). Eenzelfde letter boven de boxplots duidt gelijkenis aan, verschillende letters duiden verschil aan.

\subsection{Vijvers}

In de vijvers werd in 2016 geen vis bemonsterd. Wel werd voor de eerste keer met behulp van artificiële substraten fytobenthos gecollecteerd.

De herberekende index voor fytoplankton reflecteert het nogal troebele karakter van $\mathrm{TrBr}$ en doet de kwaliteit voor deze component dalen van matig naar ontoereikend (Figuur 44, Tabel 51). Er werden opnieuw geen submerse macrofyten aangetroffen. De macroinvertebratengemeenschap evolueerde licht gunstig.

In Wpk1 blijft een heldere watertoestand en een relatief rijke submerse vegetatie gehandhaafd, overeenstemmend met een verarmde variant van habitattype H3150 (Figuur 45, Tabel 52). Net als waargenomen gedurende andere campagnes, ondervinden de submerse macrofyten in WPk1 grote hinder van overwoekerende filamenteuze algen en perifyton in de loop van de zomer, zeker in de stroomafwaartse sectie. In 2016 kwamen in dit deel van de vijver verspreide, zich uitbreidende zones gekenmerkt door vermoedelijk purper-zwavelbacteriën voor (Figuur 46), die de submerse vegetatie plaatselijk verdrongen.

Wtml werd tussen 2013 en 2016 leeggelaten en gebiomanipuleerd, maar de vijver blijft matig scoren op vlak van fytoplankton (mede door een bloei in juni) (Figuur 47, 
Tabel 53). Desondanks kwamen meerdere soorten submerse macrofyten voor, blijft de EQR voor macroinvertebraten goed en werden in tegenstelling tot 2013 geen scholen juveniele vis geobserveerd. Niettegenstaande de matige globale ecologische status lijkt in Wtml het potentieel aanwezig voor herstel van de algemene kwaliteit.

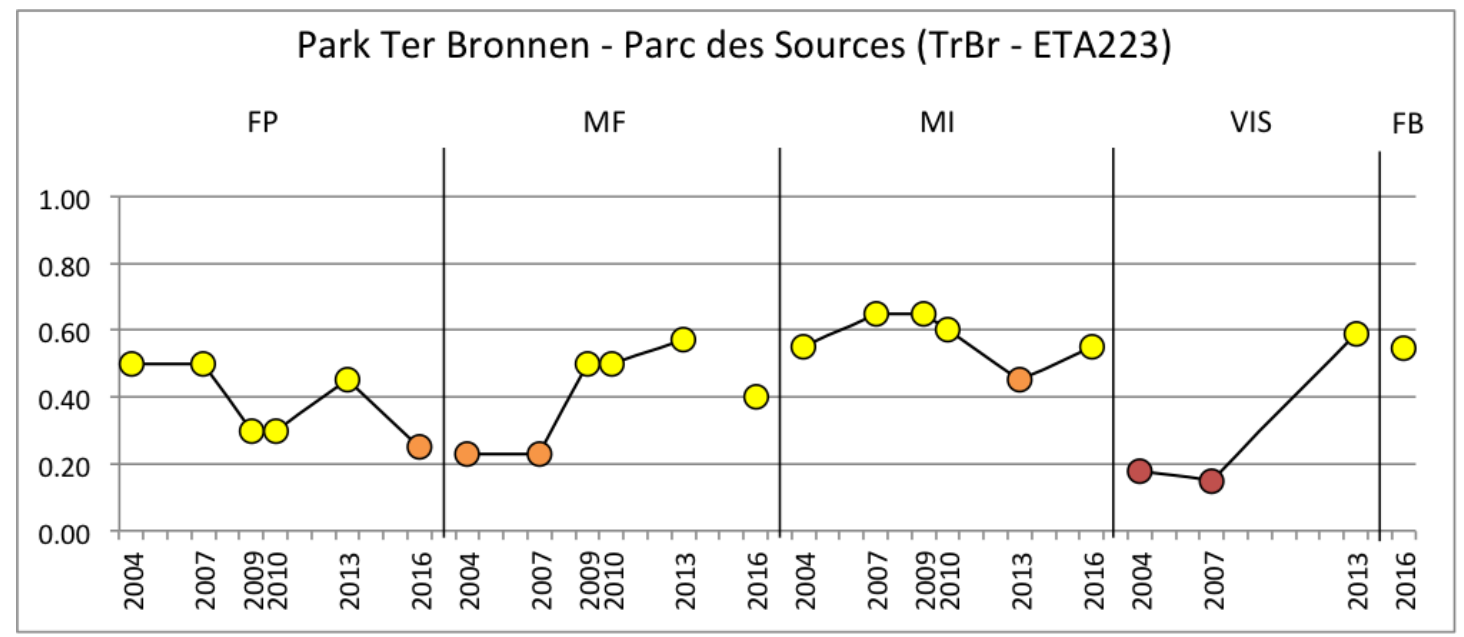

Figuur 44: Temporele evolutie van EQR in $\mathrm{TrBr}$.

Tabel 51: Temporele evolutie van EQR in $\mathrm{TrBr}$.

\begin{tabular}{l|ccccccc}
\hline TrBr - ETA223 & 2004 & 2007 & 2009 & 2010 & 2013 & 2016 \\
\cline { 2 - 8 } & & & & & & \\
FP & 0.50 & 0.50 & 0.30 & 0.30 & 0.45 & 0.25 \\
FB & nvt & nvt & nvt & nvt & nvt & 0.55 \\
MF & 0.23 & 0.23 & 0.50 & 0.50 & 0.57 & 0.40 \\
MI & 0.55 & 0.65 & 0.65 & 0.65 & 0.60 & 0.45 & 0.55 \\
VIS & 0.18 & 0.15 & nvt & nvt & 0.59 & nvt \\
& & & & & & \\
GLOBAAL (OoAo) & $\mathrm{S}$ & $\mathrm{S}$ & $\mathrm{M}$ & $\mathrm{M}$ & $\mathrm{O}$ & $\mathrm{O}$ \\
\hline
\end{tabular}

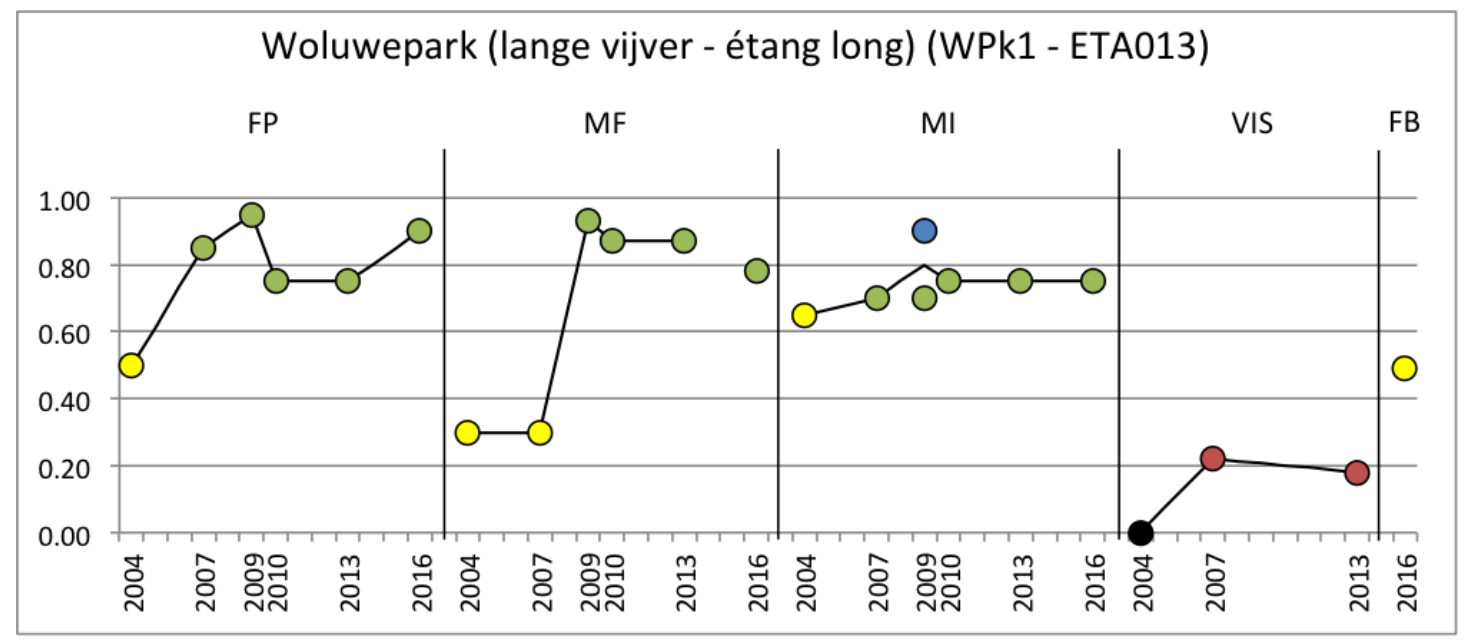

Figuur 45: Temporele evolutie van EQR in WPk1. 
Tabel 52: Temporele evolutie van EQR in WPk1.

\begin{tabular}{|c|c|c|c|c|c|c|}
\hline WPk1 - ETA013 & 2004 & 2007 & 2009 & 2010 & 2013 & 2016 \\
\hline FP & 0.50 & 0.85 & 0.95 & 0.75 & 0.75 & 0.90 \\
\hline FB & nvt & nvt & nvt nvt & nvt & nvt & 0.49 \\
\hline MF & 0.30 & 0.30 & 0.93 & 0.87 & 0.87 & 0.78 \\
\hline MI & 0.65 & 0.70 & $0.90 \quad 0.70$ & 0.75 & 0.75 & 0.75 \\
\hline VIS & 0.00 & 0.22 & nvt & nvt & 0.18 & nvt \\
\hline GLOBAAL (OoAo) & S & $S$ & GEP & GEP & $S$ & $M$ \\
\hline
\end{tabular}

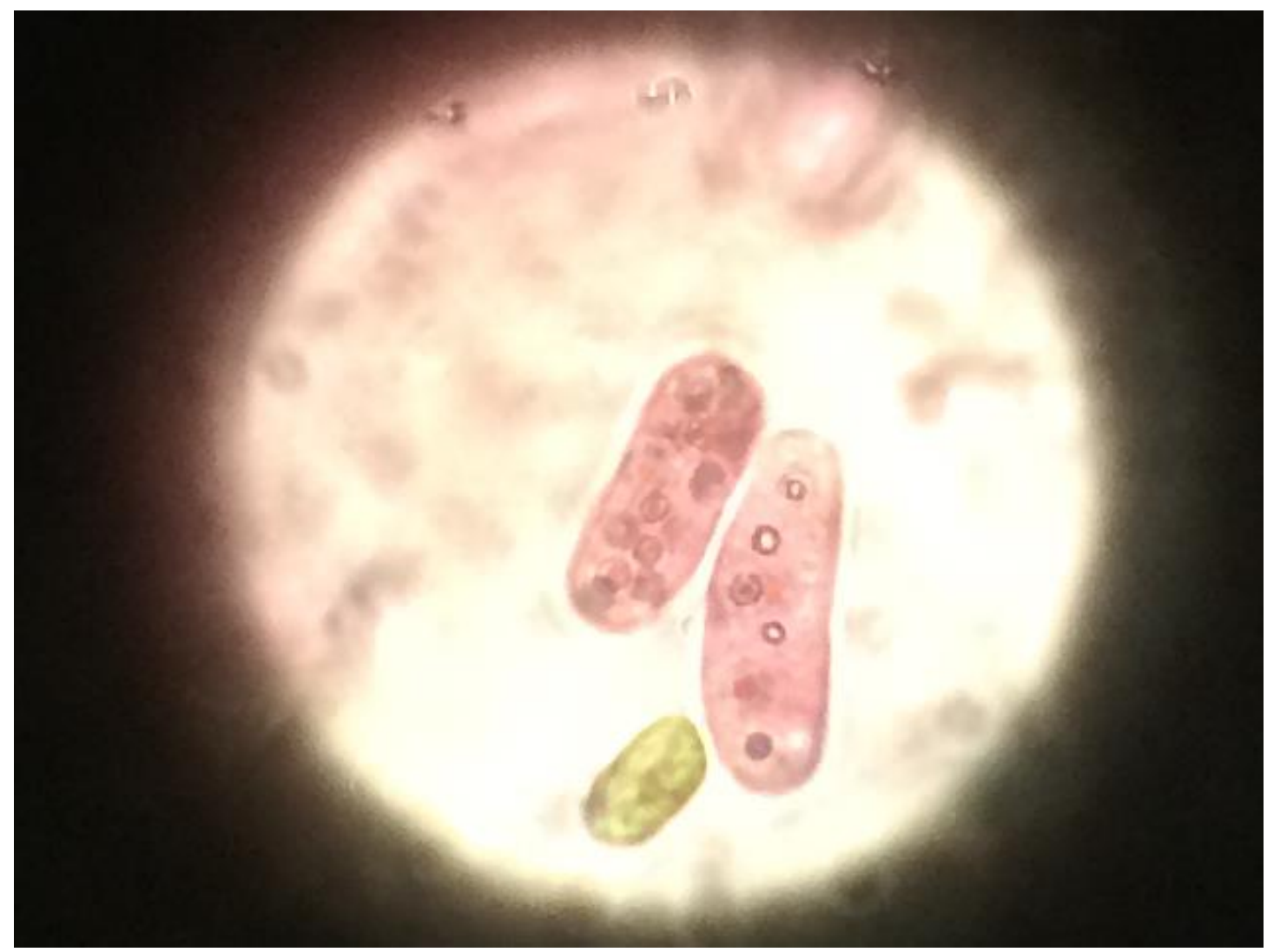

Figuur 46: Cf. Chromatium in WPk1, augustus 2016. 


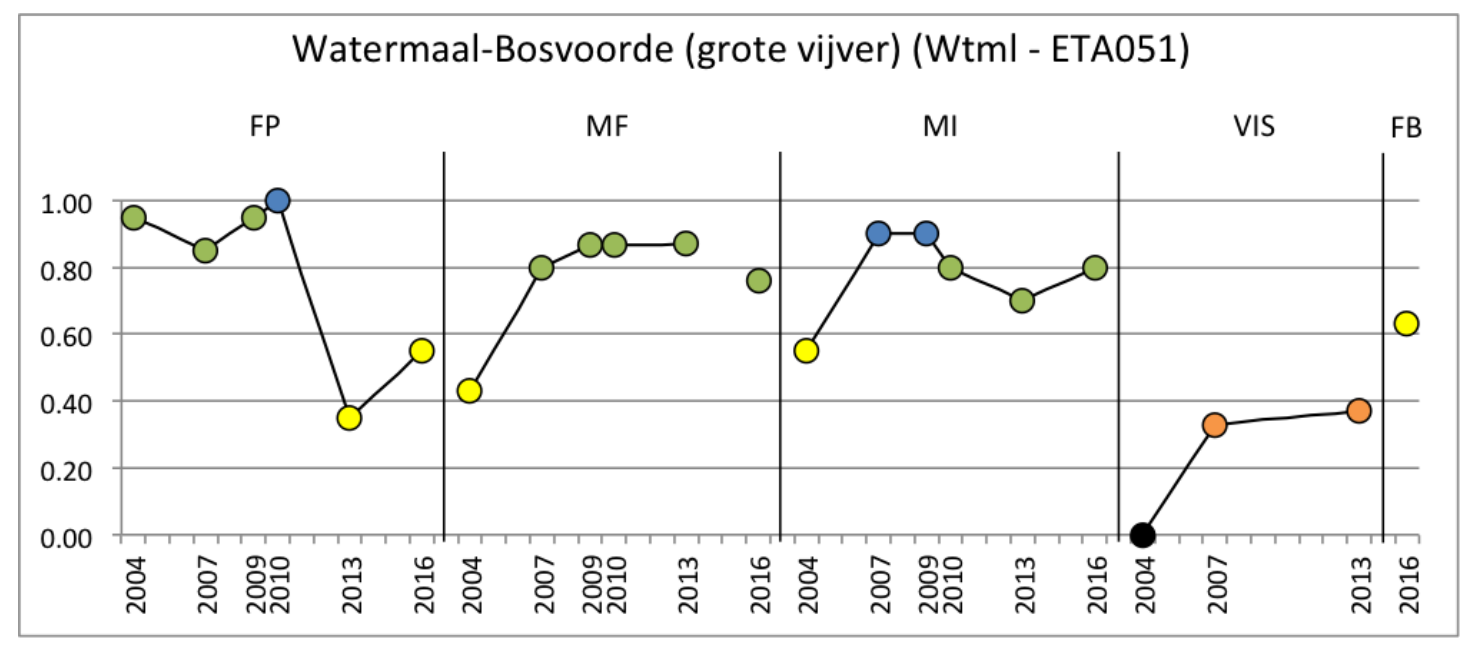

Figuur 47: Temporele evolutie van EQR in Wtml.

Tabel 53: Temporele evolutie van EQR in Wtml.

\begin{tabular}{lccccccc}
\hline Wtml - ETA051 & 2004 & 2007 & 2009 & 2010 & 2013 & 2016 \\
\cline { 2 - 8 } & & & & & & \\
FP & 0.95 & 0.85 & 0.95 & 1.00 & 0.35 & 0.55 \\
FB & nvt & nvt & nvt & nvt & nvt & 0.63 \\
MF & 0.43 & 0.80 & 0.87 & 0.87 & 0.87 & 0.76 \\
MI & 0.55 & 0.90 & 0.90 & 0.90 & 0.80 & 0.70 & 0.80 \\
VIS & 0.00 & 0.33 & nvt & nvt & 0.37 & nvt \\
& & & & & & & \\
GLOBAAL (OoAo) & $\mathrm{S}$ & 0 & GEP & GEP & 0 & M \\
\hline
\end{tabular}




\section{Synthese}

Figuur 48 en Tabel 54 geven een overzicht van de globale kwaliteit voor de geteste biologische kwaliteitselementen in 2016 of sinds 2004, op basis van het 'one-out, allout'-principe.

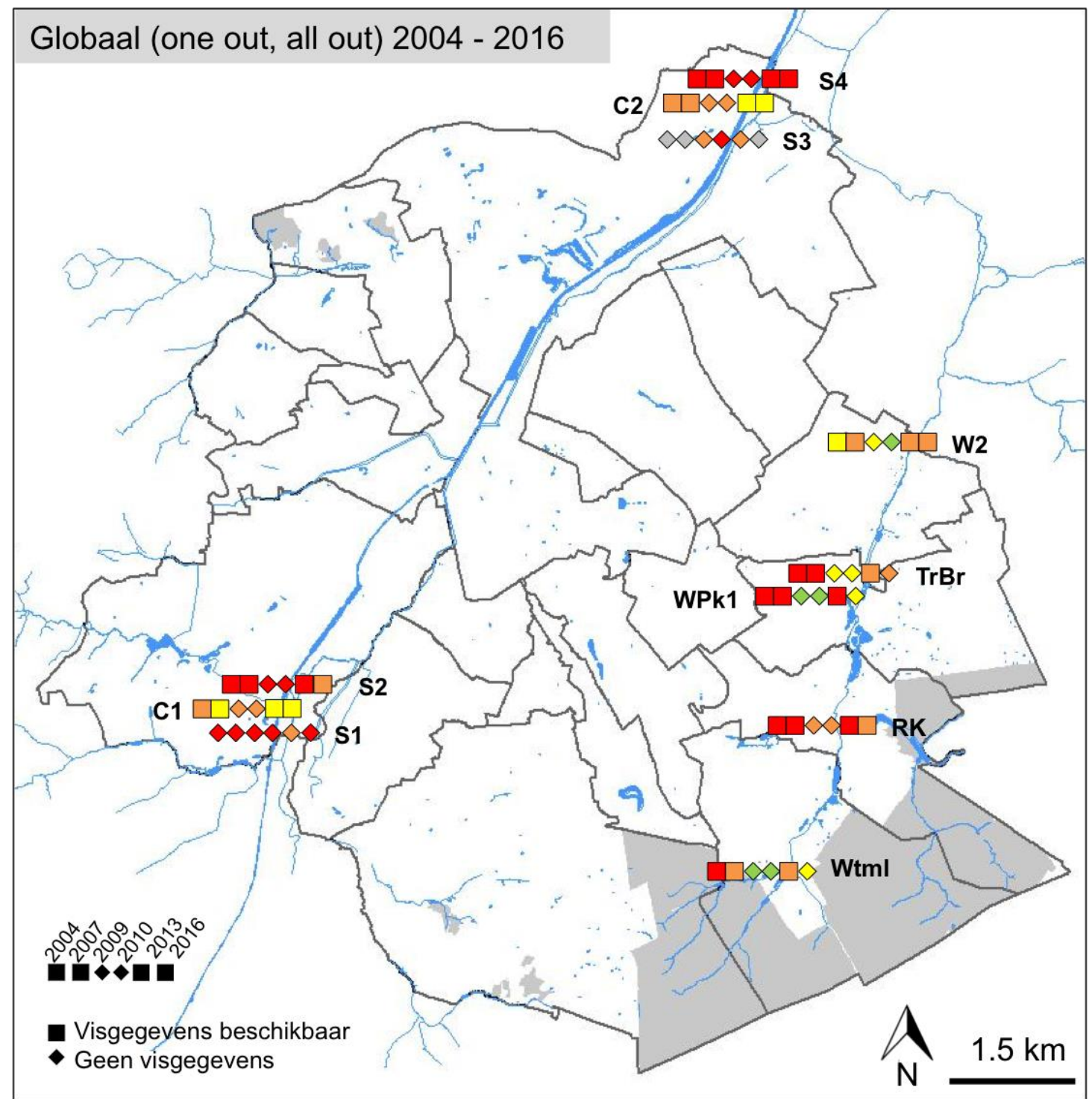

Figuur 48: Synthese van de evolutie van globale ecologische kwaliteit in het Brussels Hoofdstedelijk Gewest. 
Tabel 54: Overzicht van de EQR in 2016. *: combinatie voor- en najaarsvangst voor vis; **: temporele en ruimtelijke integratie voor volledige waterlichaam. 'onderst.': ondersteunende (a)biotiek.

\begin{tabular}{|c|c|c|c|c|c|c|c|c|c|c|}
\hline & RK & S1 & S2 & S4 & W2 & C1 & $\mathrm{C} 2$ & $\mathrm{TrBr}$ & WPk1 & Wtml \\
\hline Fytoplankton & nvt & nvt & nvt & nvt & nvt & 0.70 & 0.90 & 0.25 & 0.90 & 0.55 \\
\hline Fytobenthos & 0.78 & 0.54 & nvt & 0.53 & 0.58 & 0.64 & 0.49 & 0.55 & 0.49 & 0.63 \\
\hline Macrofyten & 0.16 & 0.00 & nvt & 0.40 & 0.88 & nvt & nvt & 0.40 & 0.78 & 0.76 \\
\hline Macro-invertebraten & 0.82 & 0.40 & nvt & 0.20 & 0.64 & 0.63 & 0.63 & 0.55 & 0.75 & 0.80 \\
\hline Vissen & $0.31 *$ & nvt & & & $0.49 *$ & & & nvt & nvt & nvt \\
\hline Ondersteunende (a)biotiek & nvt & nvt & nvt & nvt & nvt & M & 0 & 0 & G & G \\
\hline GLOBAAL (excl. onderst.) & 0 & $S$ & $\mathrm{O}$ & $S$ & 0 & $M$ & $M$ & 0 & $M$ & $M$ \\
\hline GLOBAAL (incl. onderst.) & nvt & nvt & nvt & nvt & nvt & $M$ & 0 & 0 & M & $M$ \\
\hline
\end{tabular}




\section{Referenties}

Angermeier PL \& Smogor RA (1994) Estimating number of species and relative abundances in streamfish communities: effects of sampling effort and discontinuous spatial distribution. Canadian Journal of Aquatic Science 52: 936-949

Beaumont WRC, Taylor AAL, Lee MJ \& Taylor JS (2002) Guidelines for Electric Fishing best Practice. R\&D Technical Report W2-054/TR, Environment Agency, Swindon. 188 pp

Belgisch Staatsblad (2016) 17 DECEMBER 2015. - Besluit van de Brusselse Hoofdstedelijke Regering tot wijziging van het besluit van de Brusselse Hoofdstedelijke Regering van 24 maart 2011 tot vaststelling van de milieukwaliteitsnormen, de basiskwaliteitsnormen en de chemische normen voor de oppervlaktewateren tegen de verontreiniging veroorzaakt door bepaalde gevaarlijke stoffen en andere verontreinigende stoffen. Belgisch Staatsblad: 456-474

Belpaire C, Smolders R, Vanden Auweele I, Erecken D, Breine J, Van Thuyne G \& Ollevier F (2000) An Index of Biotic Integrity characterizing fish populations and the ecological quality of Flandrian waterbodies. Hydrobiologia, 434: 17-33

Boedeltje G, Smolders AJP, Roelofs JGM \& Van Groenendael JM (2001) Constructed shallow zones along navigation canals: vegetation establishment and change in relation to environmental characteristics. Aquatic Conservation: Marine and Freshwater Ecosystems 11: 453-471

Breine J, Simoens I, Haidvogl G, Melcher A, Pont D, Schmutz S \& the FAME CONSORTIUM (2005) Manual for the application of the European Fish Index - EFI. A fish-based method to assess the ecological status of European rivers in support of the Water Framework Directive. Version 1.1, Januari 2005. $81 \mathrm{pp}$

Breine J, Van Thuyne G \& De Bruyn L (2015) Development of a fish-based index combining data from different types of fishing gear: A case study of reservoirs in Flanders (Belgium). Freshwater Biology. Belgian Journal of Zoology 145: 17-39

Carreira BM, Dias MP \& Rebelo R (2014) How consumption and fragmentation of macrophytes by the invasive crayfish Procambarus clarkii shape the macrophyte communities of temporary ponds. Hydrobiologia 721: 89-98

CEN document (2002) Water analysis, sampling of fish with electricity. CEN/TC 230/WG 2/TG 4 N 27. Work Item 230116, prEN 14011, 14 pp

De Backer S, Teissier S \& Triest L (2014) Identification of total phosphate, submerged vegetation cover and zooplankton size thresholds for success of biomanipulation in peri-urban eutrophic ponds. Hydrobiologia 737: 281-296

De Leeuw J, Buijse AD, Haidvogl G, Lapinska M, Noble R, Repecka R, Virbickas T, Wisniewolski W \& Wolter C (2007) Challenges in developing fish-based ecological assessment methods for large floodplain rivers. Fisheries Management and Ecology 14: 483-494

EC (2000) Directive of the European parliament and of the council 2000/60/EC establishing a framework for community action in the field of water policy. Official Journal of the European Communities 22.12.2000 L 327/1

EC (2007) Interpretation Manual of European Union Habitats - EU 27. Europese Commissie, 142 pp

EC (2008) Beschikking van de Commissie van 30 oktober 2008 tot vaststelling van de indelingswaarden voor de monitoringsystemen van de lidstaten die het resultaat zijn van de intercalibratie, overeenkomstig Richtlijn 2000/60/EG van het Europees Parlement en de Raad. Publicatieblad van de Europese Unie, L 332/20-44

EC (2014) Regulation of the European parliament and of the council 1143/2014 on the prevention and management of the introduction and spread of invasive alien species. Official Journal of the European Communities 4.11.2014 L 7/35 
EEC (1992) Council Directive 92/43/EEC of 21 May 1992 on the conservation of natural habitats and of wild fauna and flora. Official Journal L 206 , 22/07/1992 P. 0007 - 0050

EPA (2010) Standard operating procedure for phytoplankton analysis. LG401. Rapport, US Environmental Protection Agency, 42 pp

Europese Commissie (2008) Beschikking van de Commissie van 30 oktober 2008 tot vaststelling van de indelingswaarden voor de monitoringsystemen van de lidstaten die het resultaat zijn van de intercalibratie, overeenkomstig Richtlijn 2000/60/EG van het Europees Parlement en de Raad. Publicatieblad van de Europese Unie, L 332/20-44

Goffaux D, Roset N, Breine J, De Leeuw JJ, Oberdorff T, Gerard P, Micha J-C \& Kestemont P (2003) Selection of the most appropriate sampling technique and compilation of a common data set as a basis for standardizing a fish-based index between three European countries. Biological Evaluation and Monitoring of the Quality of Surface Waters (Edited by J.-J. Symoens \& K. Wouters). pp 111-129

Hillebrand H (1983) Development and dynamics of floating clusters of filamentous algae. In: Wetzel RG (ed.) Periphyton of Freshwater Ecosystems. Proceedings of the First International Workshop on Periphyton of Freshwater Ecosystems, Växjö, Sweden, 14-17 September 1982

Hillebrand H, Dürselen C-D, Kirschtel D, Pollingher U \& Zohary T (1999) Biovolume calculation for pelagic and benthic microalgae. J Phycol 35: 403-424

Hughes RM (1995) Defining acceptable biological status by comparing with reference conditions. In Davis, W.S. en Simon, T.P. (Eds) Biological assessment and criteria; tools for water resource planning and decision making, Lewis Publishers, 31-47

IUCN (2009) Global Invasive Species Database (2016) - Species profile: Eriocheir sinensis. Geraadpleegd op http://www.iucngisd.org/gisd/speciesname/Eriocheir+sinensis op $21 / 12 / 2016$

Jochems H, Schneiders A, Denys L \& Van den Bergh E (2002) Typologie van de oppervlaktewateren in Vlaanderen. Eindverslag van het project VMM. KRW-Typologie.2001 (met CD-ROM), 51 pp

Jones JI \& Sayer CD (2003) Does the fish-invertebrate-periphyton cascade precipitate plant loss in shallow lakes? Ecology 84: 2155-2167

JRC (2014) Water Framework Directive Intercalibration Technical Report: Lake phytobenthos ecological assessment methods. Joint Research Centre, Institute for Environment and Sustainability, Luxembourg, $121 \mathrm{pp}$

Kelly M, Urbanic G, Acs E, Bennion $H$, Bertrin V, Burgess A, Denys L, Gottschalk S, KahlertM, Karjalainen SM, Kennedy B, Kosi G, Marchetto A, Morin S, Picinska-Fałtynowicz J, Poikane S, Rosebery J, Schoenfelder I, Schoenfelder J \& Varbiro G (2014) Comparing aspirations: intercalibration of ecological status concepts across European lakes for littoral diatoms. Hydrobiologia 734: 125-141

Kelly MG, Adams C, Graves AC, Jamieson J, Krokowski J, Lycett EB, Murray-Bligh J, Pritchard S \& Wilkins C (2001) The Trophic Diatom Index: A user's manual. Revised Edition. Environment Agency, Bristol, R\&D Technical Report E2/TR2, 135 pp

Kruse CG, Hubert WA \& Rahel FJ (1998) Single-pass electrofishing predicts trout abundance in mountain streams with sparse habitat. North American Journal of Fisheries Management 18: 940-946

Meffe GK \& Berra TM (1988) Temporal characteristics of fish assemblage structure in an Ohio stream. Copeia 3: 684-690

MNHN (2002) Cahiers d'habitats Natura 2000. Connaissance et gestion des habitats et des espèces d'intérêt communautaire. TOME 3 - Habitats humides. Rapport, Muséum national d'histoire naturelle, $457 \mathrm{pp}$

Moss B, Stephen D, Alvarez C, Becares E, van de Bund W, Collings SE, van Donk E, De Eyto E, Feldmann T, Fernandez-Alaez C, Fernandez-Alaez M, Franken RJM, Garcia-Criado F, EGross EM, Gyllstrom 
$M$, Hansson LA, Irvine $K$, Jarvalt $A$, Jensen JP, Jeppesen $E$, Kairesalo $T$, Kornijow $R$, Krause $T$, Kunnap H, Laas A, Lille E, Lorens B, Luup H, Miracle MR, Noges P, Noges T, Nykanen M, Ott I, Peczula W, Peeters E, Phillips G, Romo S, Russell V, Salujoe J, Scheffer M, Siewertsen K, Smal H, Tesch C, Timm H, Tuvikene L, Tonno I, Virro T, Vicente E, Wilson D (2003) The determination of ecological status in shallow lakes - a tested system (ECOFRAME) for implementation of the European Water Framework Directive. Aquat Conserv: Mar Freshw Ecosyst 13: 507-549

Ordinnantie Water (2006) Ordonnantie tot opstelling van een kader voor het waterbeleid Ordonnance établissant un cadre pour la politique de l'eau. Brussels-Capital Region, 20 October 2006

Pegg MA \& Pierce CL (2002) Fish community structure in the Missouri and lower Yellowstone rivers in relation to flow characteristics. Hydrobiologia 479: 155-167

Penczak T (2011) Fish assemblages composition in a natural, then regulated, stream: A quantitative long-term study. Ecological modelling 222: 2103-2188

Peretyatko A, Teissier S, De Backer S \& Triest L (2012b) Classification trees as a tool for predicting cyanobacterial blooms. Hydrobiologia 689: 131-146

Peretyatko A, Teissier S, Symoens JJ \& Triest L (2007) Phytoplankton biomass and environmental factors over a gradient of clear to turbid peri-urban ponds. Aquatic Conserv: Mar Freshw Ecosyst 17: 584-601

Prygiel J, Leveque L \& Iserentant R (1996) Un nouvel indice diatomique pratique pour l'évaluation de la qualité des eaux en réseau de surveillance. Revue des Sciences de l’Eau 1: 97-113

Ramm AEL (1990) Application of the community degradation index to South African estuaries. Water Research 24: 383-389

Regis J, Pattee E \& Lebreton JD (1981) A new method for evaluating the efficiency of electric fishing. Archives Hydrobiology 93: 68-82

Reynolds CS (2006) The ecology of phytoplankton. Cambridge, Cambridge University Press, 535 pp

Snyder DE (2003) Electrofishing and its harmful effects on fish. USGS Information and Technology Report USGS/BRD/ITR 2003-0002. 149 pp

T'jollyn F, Bosch H, Demolder H, De Saeger S, Leyssen A, Thomaes A, Wouters J, Paelinckx D \& Hoffmann M (2009) Ontwikkeling van criteria voor de beoordeling van de lokale staat van instandhouding van de Natura 2000 habitattypen. Versie 2.0. Report, Instituut voor Natuur- en Bosonderzoek INBO.R.2009.46, 326 pp

Triest L, Breine J, Crohain N \& Josens G (2008) Evaluatie van de ecologische staat van sterk veranderde en kunstmatige waterlichamen in het Brussels Hoofdstedelijk Gewest zoals bepaald in de Kaderrichtlijn Water 2000/60/EG, INBO.R.2008.5, 226 pp

Vadrucci MR, Mazziotti C \& Fiocca A (2013) Cell biovolume and surface area in phytoplankton of Mediterranean transitional water ecosystems: methodological aspects. Transit Waters Bull 7: 100-123

Van der Wal JEM, Dorenbosch M, Immers AK, Vidal Forteza C, Geurts JJM, Peeters ETHM, Koese B \& Bakker ES (2013) Invasive Crayfish Threaten the Development of Submerged Macrophytes in Lake Restoration. PLOS ONE 8: 1-11

Van Onsem S \& Triest L (2012) Ecologische kwaliteitsbeoordeling op basis van fytobenthos in het kanaal Charleroi-Brussel-Schelde - Vergelijking van methoden gebruikt in Vlaanderen en het Brussels Hoofdstedelijk Gewest. Rapport, VUB, 24 pp

Van Onsem S \& Triest L (2015) Integration of ecological monitoring protocols for ponds in the Brussels-Capital Region. Streamlining of methodologies for Water Framework Directive, Habitats Directive and Cyanobacterial surveillance. Rapport, VUB, $126 \mathrm{pp}$ 
Van Onsem S, Triest L, Crohain N \& Josens G (2012) Beoordeling van de ecologische kwaliteit van waterlichamen in het Brussels Hoofdstedelijk Gewest in uitvoering van de Europese Kaderrichtlijn Water. Rapport, VUB, Brussels, 203 pp

Van Onsem S, Breine J \& Triest L (2014) De ecologische kwaliteit van waterlopen, kanalen en vijvers in het Brussels Hoofdstedelijk gewest in 2013. Fytoplankton, fytobenthos, macrofyten, macroinvertebraten en vissen. INBO.R.2014.1509324. 117 pp

Van Tendeloo A, Gosset G, Breine J, Belpaire C, Josens G \& Triest L (2004) Uitwerking van een ecologische-analyse methodologie voor sterk veranderde en kunstmatige waterlichamen in het Brussels Hoofdstedelijk Gewest in toepassing van de Kaderrichtlijn Water 2000/60/EG, 190 pp + annex $75 \mathrm{pp}$

Van Thuyne G (2003) Visbestanden op het Kanaal Charleroi-Brussel-Schelde (2002). IBW.Wb.V.IR.2003.139, $11 \mathrm{pp}$

Verreycken H, Anseeuw D, Van Thuyne G, Quataert P \& Belpaire C (2007) The nonindigenous freshwater fishes of Flanders (Belgium): review, status and trends over the last decade. Journal of Fish Biology 71 (Supplement D): 160-172

VMM (2009) Biological assessment of the natural, heavily modified and artificial surface water bodies in Flanders according to the European Water Framework Directive. Rapport, Vlaamse Milieumaatschappij, $78 \mathrm{pp}$

Vrielynck S, Belpaire C, Stabel A, Breine J \& Quataert P (2002) De visbestanden in Vlaanderen anno 1840-1950. Een historische schets van de referentietoestand van onze waterlopen aan de hand van de visstand, ingevoerd in een databank en vergeleken met de actuele toestand. Instituut voor Bosbouw en Wildbeheer en Afdeling Water (AMINAL), Groenendaal, $271 \mathrm{pp}$

Whiteside BG \& McNatt RM (1972) Fish species diversity in relation to stream order and physicochemical conditions in the Plum creek drainage basin. American Midland naturalist 88 90-101

Wobbrock JO, Findlater L, Gergle D \& Higgins JJ (2011) The Aligned Rank Transform for nonparametric factorial analyses using only ANOVA procedures. Proceedings of the 2011 annual conference on Human factors in computing systems, 143-146 


\section{Bijlagen}

Appendix 1: Diatomeeën in kanaal, waterlopen en vijvers in 2016.

\begin{tabular}{|c|c|c|c|c|c|c|c|c|c|c|}
\hline Taxon & C1_16 & C2_16 & RK_16 & S1_16 & S4_16 & W2_16 & TrBr_16 & WPk1_16 & Wtml_16 & \# locaties \\
\hline Achnanthidium minutissimum & 5.5 & & 46.0 & 5.0 & 10.0 & 44.0 & 52.0 & 36.0 & 105.0 & 8 \\
\hline Actinocyclus normanii & 6.0 & 3.0 & & 3.0 & & & & & & 3 \\
\hline Amphora copulata & 20.0 & & 55.0 & 11.0 & & 7.0 & 1.0 & 17.0 & 16.0 & 7 \\
\hline Amphora ovalis & & & 6.0 & & & & & 2.0 & 3.0 & 3 \\
\hline Amphora pediculus & 7.0 & & 198.0 & 14.0 & 10.0 & 15.0 & 69.0 & 34.0 & 39.0 & 8 \\
\hline Anomoeoneis sphaerophora & & & 1.0 & & & & & 2.0 & & 2 \\
\hline Aulacoseira ambigua & 1.0 & & & & 2.0 & 1.0 & 2.0 & & & 4 \\
\hline Aulacoseira distans & & & 0.0 & & & & & & & 1 \\
\hline Aulacoseira granulata & & & & 5.0 & 3.0 & 3.0 & 2.0 & & & 4 \\
\hline Aulacoseira subarctica & & & & 17.0 & & 1.0 & & & & 2 \\
\hline Bacillaria paradoxa & 10.0 & 2.0 & & 2.0 & & & & & & 3 \\
\hline Caloneis amphisbaena & & & & & & 2.0 & & & & 1 \\
\hline Caloneis lancetulla & 4.0 & 7.0 & & & & & & & & 2 \\
\hline Caloneis silicula & & & & & & & 2.0 & & & 1 \\
\hline Cocconeis pediculus & 2.0 & 1.0 & 1.0 & 25.0 & 12.0 & & 1.0 & 4.0 & & 7 \\
\hline Cocconeis placentula & 8.0 & 8.0 & 17.0 & 17.0 & 26.0 & 16.0 & 16.0 & 27.0 & 17.0 & 9 \\
\hline Craticula cuspidata & 1.0 & & & & 2.0 & & 1.0 & & & 3 \\
\hline Ctenophora pulchella & & 2.0 & & & & & & & & 1 \\
\hline Cyclostephanos dubius & 2.0 & 1.0 & 2.0 & & 7.0 & 3.0 & 81.0 & & & 6 \\
\hline Cyclotella atomus & & & & 17.0 & 23.0 & 4.0 & 5.0 & & 7.0 & 5 \\
\hline Cyclotella meneghiniana & 13.0 & 12.0 & & 7.0 & 9.0 & 1.0 & 22.0 & & & 6 \\
\hline Cymatopleura solea & & & & 1.0 & & & & & & 1 \\
\hline Cymbella excisa & & & & & & & & & 1.0 & 1 \\
\hline Cymbella hustedtii var. hustedtii & & & & & & & 1.0 & & & 1 \\
\hline Cymbella lanceolata & & & 2.0 & & & & & & & 1 \\
\hline Cymbella neocistula & & & & & & & 8.0 & & & 1 \\
\hline Cymbella pervarians & & & & & & & & 2.0 & & 1 \\
\hline Cymbella stigmaphora & & & & & & & & 2.0 & & 1 \\
\hline Cymbopleura inaequalis & & & & & & 2.0 & & & & 1 \\
\hline Diatoma problematica & & & & 1.0 & & & & & & 1 \\
\hline Diatoma vulgaris & & & & 2.0 & 2.0 & & & & & 2 \\
\hline Encyonema caespitosum & & & & & & & & 6.0 & & 1 \\
\hline Encyonema silesiacum & 8.0 & & & & & 25.0 & 1.0 & & & 3 \\
\hline Eolimna minima & 12.6 & 2.0 & 4.0 & 4.7 & 9.0 & & 27.0 & 25.0 & 53.0 & 8 \\
\hline Eolimna subminuscula & & & & & 1.0 & & & & & 1 \\
\hline Epithemia adnata & & & & 2.0 & & & & & 12.3 & 2 \\
\hline Epithemia sorex & & & & & & & & & 36.8 & 1 \\
\hline Fallacia monoculata & & & & 13.0 & 1.0 & & & & & 2 \\
\hline Fallacia subhamulata & 1.0 & & 6.0 & & & 4.0 & & & & 3 \\
\hline Fistulifera saprophila & 4.0 & 1.0 & & 2.3 & & 2.0 & & & 2.0 & 5 \\
\hline Fragilaria capucina & & & & 2.0 & & & & & & 1 \\
\hline Fragilaria vaucheriae & & & & 2.0 & 2.0 & 2.0 & & & 5.0 & 4 \\
\hline Frustulia vulgaris & & & & 1.0 & 4.0 & & & & & 2 \\
\hline Gomphonema acuminatum & & & & & & 1.0 & & & & 1 \\
\hline Gomphonema auritum & & & 3.0 & & & & & & & 1 \\
\hline Gomphonema gracile & & & & 3.3 & & & & & & 1 \\
\hline Gomphonema micropus & & 3.4 & & & 1.7 & & & & & 2 \\
\hline Gomphonema minutum & 2.0 & 3.0 & & & & & & & & 2 \\
\hline Gomphonema parvulum & 61.0 & 37.6 & 12.0 & 16.7 & 24.3 & 80.0 & 42.0 & 214.0 & 132.0 & 9 \\
\hline Gomphonema pumilum & & & & & 1.0 & 8.0 & & & 9.0 & 3 \\
\hline Gomphonema subclavatum & & 2.0 & & & & & & & & 1 \\
\hline Gomphonema truncatum & & 3.0 & 3.0 & & & & 3.0 & 12.0 & & 4 \\
\hline Gyrosigma acuminatum & 5.0 & 1.0 & & 1.0 & & & & & & 3 \\
\hline Gyrosigma attenuatum & 1.0 & 1.0 & & & & & & & & 2 \\
\hline Halamphora veneta & & & & & & & & 1.0 & 1.0 & 2 \\
\hline Hantzschia abundans & & & & 3.0 & & & & & & 1 \\
\hline Hantzschia amphioxys & & & & 4.0 & 1.0 & & & & & 2 \\
\hline Hippodonta capitata & & & & & 3.0 & 9.0 & & 1.0 & & 3 \\
\hline Karayevia clevei & & & 22.0 & & & & & & & 1 \\
\hline Luticola goeppertiana & & 9.0 & & 1.0 & 4.0 & & & & & 3 \\
\hline Luticola mutica & & & & 13.0 & 2.0 & & & & & 2 \\
\hline Luticola nivalis & & & & 2.0 & 2.0 & & & & & 2 \\
\hline Mayamaea atomus & & & & 7.0 & & & & & & 1 \\
\hline Melosira varians & 20.0 & 17.0 & & 2.0 & & 2.0 & & & 2.0 & 5 \\
\hline Meridion circulare & & & & 9.0 & & & & & & 1 \\
\hline Navicula antonii & 77.8 & 50.1 & 2.0 & & 5.7 & 14.7 & & & & 5 \\
\hline Navicula cari & & & & & 2.0 & & & & & 1 \\
\hline Navicula cincta & & & & 2.5 & 1.1 & & & & & 2 \\
\hline Navicula cryptocephala & & & & & 4.0 & & & & 4.0 & 2 \\
\hline Navicula cryptotenella & 4.0 & 2.0 & 2.0 & 12.0 & & 2.0 & 4.0 & 5.3 & 4.0 & 8 \\
\hline Navicula cryptotenelloides & & & & & & & & 4.0 & 6.0 & 2 \\
\hline Navicula gregaria & & & & 19.0 & 47.0 & 20.0 & & & & 3 \\
\hline Navicula lanceolata & & 1.0 & & 50.7 & 88.4 & & & & & 3 \\
\hline Navicula menisculus & & & & & & & & & 1.0 & 1 \\
\hline Navicula protracta & & 4.0 & & & & & & & & 1 \\
\hline Navicula radiosa & & & & & & 6.0 & & 3.0 & & 2 \\
\hline Navicula recens & 7.2 & 183.9 & 1.0 & & & 3.7 & & 2.7 & & 5 \\
\hline Navicula reichardtiana & & & & & & 3.7 & & & & 1 \\
\hline Navicula reinhardtii & & & & & & 1.0 & & & & 1 \\
\hline Navicula slesvicensis & & & & 3.0 & & & & & & 1 \\
\hline Navicula tripunctata & 123.0 & 16.0 & 13.0 & 23.3 & 6.6 & 4.0 & 2.0 & 2.0 & & 8 \\
\hline Navicula trivialis & & & & & 4.0 & 3.0 & 2.0 & 2.0 & & 4 \\
\hline Navicula trophicatrix & & & & & & 2.0 & & 2.0 & & 2 \\
\hline Navicula upsaliensis & & & & & & 2.0 & & 3.0 & & 2 \\
\hline Navicula veneta & & & & 4.0 & 9.1 & & & & & 2 \\
\hline Navicula vilaplanii & & & & & 1.1 & & & & & 1 \\
\hline
\end{tabular}




\begin{tabular}{|c|c|c|c|c|c|c|c|c|c|c|}
\hline Taxon & C1_16 & C2_16 & RK_16 & S1_16 & S4_16 & W2_16 & TrBr_16 & WPk1_16 & Wtml_16 & \#locaties \\
\hline Neidium ampliatum & & & 1.0 & & & & & & & 1 \\
\hline Nitzschia acicularis & & & & & & 2.0 & & & & 1 \\
\hline Nitzschia amphibia & & & & & 1.0 & & & & & 1 \\
\hline Nitzschia capitellata & & & & 2.0 & 2.0 & 6.0 & & & & 3 \\
\hline Nitzschia denticula & & & 2.0 & 2.0 & & & & & & 2 \\
\hline Nitzschia dissipata & 14.0 & 2.0 & & & 2.0 & 1.8 & & & & 4 \\
\hline Nitzschia dissipata var. media & & & 1.0 & & 2.0 & & & & & 2 \\
\hline Nitzschia dubia & & & & & 1.0 & & & & & 1 \\
\hline Nitzschia filiformis & & 53.0 & & & & & & & & 1 \\
\hline Nitzschia fonticola & & 1.0 & & & & & & 1.0 & 5.0 & 3 \\
\hline Nitzschia frustulum var. bulnheimiana & & & & 6.0 & 5.0 & 8.0 & 109.0 & 76.0 & 4.0 & 6 \\
\hline Nitzschia frustulum var. frustulum & 2.0 & & & & & & & & & 1 \\
\hline Nitzschia frustulum var. inconspicua & & & & & 8.0 & & & & & 1 \\
\hline Nitzschia intermedia & & & & & 2.0 & & & & & 1 \\
\hline Nitzschia linearis & 1.0 & & & & & 15.0 & & & & 2 \\
\hline Nitzschia microcephala & 2.0 & & & & & & & & & 1 \\
\hline Nitzschia palea & 16.0 & 20.0 & & 3.3 & 9.0 & 12.0 & & 3.0 & 4.0 & 7 \\
\hline Nitzschia pusilla & & & & 6.7 & & & & & & 1 \\
\hline Nitzschia recta & 5.0 & 1.0 & 1.0 & & 1.0 & 7.2 & & & & 5 \\
\hline Nitzschia tenuis & & & & 19.0 & 7.0 & 3.0 & & & & 3 \\
\hline Nitzschia umbonata & & & & 16.0 & & & & & & 1 \\
\hline Nitzschia wuellerstorffii & & & & & & 3.0 & & & & 1 \\
\hline Pinnularia borealis & & & & 1.0 & & & & & & 1 \\
\hline Pinnularia schoenfelderi & & & & & 7.0 & & & & & 1 \\
\hline Pinnularia subgibba var. undulata & & & & & & & 7.0 & & & 1 \\
\hline Pinnularia viridiformis & & & 1.0 & & & & & & & 1 \\
\hline Pinnularia viridis & & & 1.0 & & & & & & & 1 \\
\hline Placoneis gastrum & & & 1.0 & & & & & & & 1 \\
\hline Planothidium frequentissimum & 12.0 & & 12.1 & 10.8 & 5.6 & 10.8 & 1.0 & 2.0 & 4.0 & 8 \\
\hline Planothidium lanceolatum & & & 5.5 & 16.2 & 15.4 & 2.2 & & & 1.0 & 5 \\
\hline Planothidium rostratum & & & 4.4 & & & & & & & 1 \\
\hline Platessa conspicua & & & 6.0 & & & & & & & 1 \\
\hline Psammothidium lauenburgianum & & & 26.0 & & & 4.0 & & & & 2 \\
\hline Pseudostaurosira brevistriata & & & 1.0 & & & 3.0 & & & & 2 \\
\hline Reimeria sinuata & & & & & & 7.0 & & & & 1 \\
\hline Rhoicosphenia abbreviata & 2.0 & 4.0 & 4.0 & 5.0 & 8.0 & 12.0 & 15.0 & 4.0 & & 8 \\
\hline Sellaphora pupula & & & & & & & 1.0 & & 3.0 & 2 \\
\hline Sellaphora seminulum & & & & & 2.0 & & & & & 1 \\
\hline Stauroneis kriegeri & & & & 2.0 & & & & & & 1 \\
\hline Stauroneis smithii & & & & 1.0 & & & & & & 1 \\
\hline Staurosira brevistriata & & & & & & & & & 2.0 & 1 \\
\hline Staurosira construens & & & & 6.0 & & 35.0 & & & 7.0 & 3 \\
\hline Stephanodiscus hantzschii & 15.0 & 20.0 & 12.0 & 20.0 & 20.0 & 35.0 & 8.0 & & 4.0 & 8 \\
\hline Stephanodiscus neoastraea & 4.0 & 1.0 & & & 6.0 & & & & & 3 \\
\hline Surirella angusta & & & & & 3.0 & 2.0 & & & & 2 \\
\hline Surirella brebissonii & & 1.0 & & 9.0 & 20.0 & 1.0 & & & & 4 \\
\hline Surirella terricola & & & & 2.0 & & & & & & 1 \\
\hline Tabularia fasciculata & & & & & & & 1.0 & & & 1 \\
\hline Thalassiosira bramaputrae & 25.0 & 11.0 & & & & & & & & 2 \\
\hline Thalassiosira pseudonana & 3.0 & 7.0 & 8.0 & 11.0 & 12.0 & 23.0 & 10.0 & & 8.0 & 8 \\
\hline Thalassiosira visurgis & & & & & 2.0 & & & & & 1 \\
\hline Tryblionella apiculata & & & & 2.0 & & & & & & 1 \\
\hline Tryblionella hungarica & & & & & 2.0 & & & & & 1 \\
\hline Tryblionella levidensis & & & & 2.0 & 4.0 & & & & & 2 \\
\hline Ulnaria ulna & & 3.0 & 1.0 & 19.0 & 12.9 & 1.0 & 3.0 & 3.0 & & 7 \\
\hline Ulnaria ulna var. acus & & 3.0 & 2.0 & & 7.1 & & & & & 3 \\
\hline TOTAAL & 507 & 500 & 486 & 493 & 498 & 488 & 499 & 498 & 498 & \\
\hline AANTAL TAXA & 37 & 38 & 38 & 60 & 60 & 53 & 30 & 29 & 30 & \\
\hline
\end{tabular}


Appendix 2: Macroinvertebraten in kanaal, waterlopen en vijvers. IG=Indicatorgroep (IBGN);

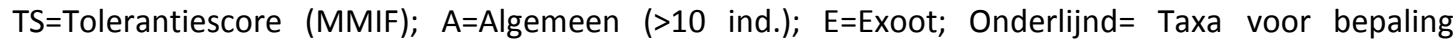
diversiteit IBGN; *=exuvia; ()=terrestrisch; ?=waargenomen.

\begin{tabular}{|c|c|c|c|c|c|c|c|c|c|c|}
\hline LOCATIE & & $\mathrm{C} 1$ & $\mathrm{C} 2$ & RK & S1 & S4 & W2 & $\mathrm{TrBr}$ & WPk1 & Wtml \\
\hline \multirow{2}{*}{$\begin{array}{l}\text { DATUM STAALNAME } \\
\text { TAXON }\end{array}$} & & $29-6$ & $29-6$ & $28-6$ & $29-6$ & $29-6$ & $28-6$ & $28-6$ & $28-6$ & $28-6$ \\
\hline & IG TS & & & & & & & & & \\
\hline Bryozoa & & & & & & & & & & \\
\hline
\end{tabular}

niet geïdentificeerd

A

\begin{tabular}{|c|c|c|c|c|c|c|c|c|c|c|c|}
\hline Annelida & & & & & & & & & & & \\
\hline Polychaeta & & & & & & & & & & & \\
\hline Ampharetidae & & 3 & & & & & & & & & \\
\hline Hypania invalida (E) & & & A & A & & & & & & & \\
\hline Clitellata & & & & & & & & & & & \\
\hline Oligochaeta & 1 & & A & A & A & A & A & A & 530 & 97 & 97 \\
\hline$\overline{\text { Lumbricidae }}$ & & 2 & & & & & & & & & \\
\hline Eiseniella & & & & & 2 & & 2 & & & & \\
\hline Tubificidae & & 1 & & & & & & & & & \\
\hline Hirudinea & 1 & & & & & & & & & & 3 \\
\hline Erpobdellidae & & & & & & & & & & & \\
\hline Erpobdella & & 3 & 3 & & 1 & A & A & & & & 6 \\
\hline Glossiphoniidae & & & & & & & & & & & \\
\hline$\overline{\text { Glossiphonia }}$ & & 4 & & & & A & A & & & & \\
\hline Helobdella & & 4 & & 2 & & A & A & & 26 & & 8 \\
\hline Theromyzon & & 4 & 1 & & & 1 & & & & & \\
\hline Piscicolidae & & & & & & & & & & & \\
\hline Piscicola & & 5 & & & & & & & 3 & 1 & \\
\hline Mollus ca & 2 & & & & & & & & & & \\
\hline Bivalvia & & & & & & & & & & & \\
\hline Corbiculidae & & & & & & & & & & & \\
\hline$\overline{\text { Corbicula }}(\mathrm{E})$ & & 5 & A & & & & & & & & \\
\hline Dreissenidae & & & & & & & & & & & \\
\hline Dreissena (E) & & 5 & A & A & & & & & & & \\
\hline Sphaeriidae & & & 1 & & 6 & & & & & 3 & \\
\hline Musculium & & 4 & & & & & & & & 3 & 24 \\
\hline Pisidium & & 4 & & & 2 & & & 3 & 10 & & 14 \\
\hline Sphaerium & & 4 & & & & 2 & & & & & \\
\hline Gas tropoda & & & & & & & & & & & \\
\hline$\underline{\text { Acroloxidae }}$ & & & & & & & & & & & \\
\hline$\overline{\text { Acroloxus }}$ & & 6 & & & & & & & 12 & & 2 \\
\hline Anisus & & 5 & & & & & & & & & 2 \\
\hline Ferrissia & & 7 & & & & & & & & 1 & \\
\hline Bithyniidae & & & & & & & & & & & \\
\hline$\overline{\text { Bithynia }}$ & & 5 & & 7 & & & & & 1 & 8 & 60 \\
\hline Lymnaeidae & & & & & & & & & & & \\
\hline$\overline{\text { Lymnaea/Radix }}$ & & 5 & & & & & & & 4 & 8 & 3 \\
\hline Physidae & & & & & 13 & & & & & & \\
\hline$\overline{\text { Physa }}$ & & 5 & & & & & & & & 3 & \\
\hline Physella & & 3 & & & & & & & & 15 & \\
\hline Planorbidae & & & & & & & & & & & \\
\hline Bathyomphalus & & 5 & & & & & & & & 1 & \\
\hline Gyraulus & & 6 & & & & & & & & 7 & 1 \\
\hline Hippeutis & & 6 & & & & & & & 11 & 2 & 4 \\
\hline Planorbarius & & 5 & & & & & & & & 8 & 1 \\
\hline Planorbis & & 6 & & & & & & & & 2 & 1 \\
\hline$\underline{\text { Valvatidae }}$ & & & & & & & & & & & \\
\hline$\overline{\text { Valvata }}$ & & 6 & & & & & & & 3 & 26 & 25 \\
\hline
\end{tabular}




\begin{tabular}{|c|c|c|c|c|c|c|c|c|c|c|c|}
\hline \multirow{3}{*}{$\begin{array}{l}\text { LOCATIE } \\
\text { DATUM STAALNAME } \\
\text { TAXON }\end{array}$} & & & \multirow{3}{*}{$\begin{array}{c}\mathrm{C} 1 \\
29-6\end{array}$} & \multirow{3}{*}{$\begin{array}{c}\mathrm{C} 2 \\
29-6\end{array}$} & \multirow{3}{*}{$\begin{array}{c}\text { RK } \\
28-6\end{array}$} & \multirow{3}{*}{$\begin{array}{c}\text { S1 } \\
29-6\end{array}$} & \multirow{3}{*}{$\begin{array}{c}\text { S4 } \\
29-6\end{array}$} & \multirow{3}{*}{$\begin{array}{c}\text { W2 } \\
28-6\end{array}$} & \multirow{3}{*}{$\begin{array}{l}\mathrm{TrBr} \\
28-6\end{array}$} & \multirow{3}{*}{$\begin{array}{c}\text { WPk1 } \\
28-6\end{array}$} & \multirow{3}{*}{$\begin{array}{l}\text { Wtml } \\
28-6\end{array}$} \\
\hline & & & & & & & & & & & \\
\hline & \multicolumn{2}{|c|}{$\overline{\text { IG TS }}$} & & & & & & & & & \\
\hline \multicolumn{12}{|l|}{ Nematomorpha } \\
\hline niet geïdentificeerd & & & & & & & 2 & & 3 & & 30 \\
\hline \multicolumn{12}{|l|}{ Arthropoda } \\
\hline \multicolumn{12}{|l|}{ Chelice rata } \\
\hline \multicolumn{12}{|l|}{ Arachnida } \\
\hline$\underline{\text { Hydracarina }}$ & & 5 & & & & & & & 74 & 6 & \\
\hline \multicolumn{12}{|l|}{ Crustacea } \\
\hline \multicolumn{12}{|l|}{ Amphipoda } \\
\hline Corophiidae & & 5 & & & & & & & & & \\
\hline Chelicorophium (E) & & & A & A & & & & & & & \\
\hline Crangonyctidae & & 4 & & & & & & & & & \\
\hline Crangonyx (E) & & & & & A & & & & 2 & & 18 \\
\hline Gammaridae & 2 & 5 & & & & & & & & & \\
\hline 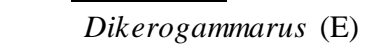 & & & A & $\mathrm{A}$ & & & & & & & \\
\hline Gammarus & & & & & & 14 & & A & & & \\
\hline Decapoda & & & & & & & & & & & \\
\hline Cambaridae & & 6 & & & & & & & & & \\
\hline Orconectes (E) & & & A & A & $\mathrm{A}$ ? & & & A? & & & \\
\hline$\underline{\text { Varunidae }}$ & & 4 & & & & & & & & & \\
\hline Eriocheir (E) & & & & A & & & $1 *$ & & & & \\
\hline Isopoda & & & & & & & & & & & \\
\hline Asellidae & 1 & 4 & & & A & $\mathrm{A}$ & $\mathrm{A}$ & & & 20 & 78 \\
\hline Asellus & & & 2 & & & & & & 2 & & \\
\hline Hexapoda & & & & & & & & & & & \\
\hline Insecta & & & & & & & & & & & \\
\hline Coleoptera & & & & & & & & & & & \\
\hline (Cleridae) & & & & & 1 & & & & & & \\
\hline Dytiscidae & & 5 & & & & & & 6 & 2 & & 3 \\
\hline$\overline{\text { Hyphydrus }}$ & & & & & & & & & & & 1 \\
\hline Hydrophilidae & & 5 & & & & & & & 1 & & \\
\hline$\overline{\text { Noteridae }}$ & & 5 & & & & & & & & & \\
\hline$\overline{\text { Noterus }}$ & & & & & & & & 1 & & & \\
\hline Diptera & & & & & & & & & & & \\
\hline Ceratopogonidae & & 3 & & & 10 & & & & & 21 & 82 \\
\hline$\overline{\text { Chaoboridae }}$ & & 3 & & & & & & & & 101 & 38 \\
\hline$\overline{\text { Chironomidae }}$ & 1 & & & & & & & & & & \\
\hline$\overline{\text { kokervormend }}$ & & & & & A & & & A & & & \\
\hline non thummi-plumosus & & 3 & $\mathrm{~A}$ & A & A & A & & A & 124 & 138 & 1014 \\
\hline thummi-plumosus & & 2 & & 2 & & & A & & 43 & 232 & 358 \\
\hline$\underline{\text { Empididae }}$ & & 3 & & & 1 & & & & & & \\
\hline$\overline{\text { Limoniidae }}$ & & 4 & & & & & & 5 & & & \\
\hline$\overline{\text { Muscidae }}$ & & 3 & & & & & 1 & & 1 & & \\
\hline$\underline{\text { Simuliidae }}$ & & 5 & & & A & & & A & 1 & & \\
\hline$\overline{\text { Tipulidae }}$ & & 3 & & & & 1 & & & & & \\
\hline$\overline{\text { (Trichoceridae) }}$ & & & & & & 1 & & & & & \\
\hline Ephemeroptera & & & & & & & & & & & \\
\hline Baetidae & 2 & & & & 7 & 4 & & A & & & \\
\hline$\overline{\text { Cloen }}$ & & 6 & & & & & & & 18 & 126 & 17 \\
\hline Caenidae & 2 & & & & & & & 1 & & & \\
\hline$\overline{\text { Caenis }}$ & & 6 & & & & & & & & 21 & 13 \\
\hline
\end{tabular}




\begin{tabular}{|c|c|c|c|c|c|c|c|c|c|c|c|}
\hline \multirow{3}{*}{$\begin{array}{l}\text { LOCATIE } \\
\text { DATUM STAALNAME } \\
\text { TAXON }\end{array}$} & & & \multirow{3}{*}{$\begin{array}{c}\mathrm{C} 1 \\
29-6\end{array}$} & \multirow{3}{*}{$\begin{array}{c}\mathrm{C} 2 \\
29-6\end{array}$} & \multirow{3}{*}{$\begin{array}{c}\text { RK } \\
28-6\end{array}$} & \multirow{3}{*}{$\begin{array}{c}\text { S1 } \\
29-6\end{array}$} & \multirow{3}{*}{$\begin{array}{c}\text { S4 } \\
29-6\end{array}$} & \multirow{3}{*}{$\begin{array}{c}\text { W2 } \\
28-6\end{array}$} & \multirow{3}{*}{$\begin{array}{l}\mathrm{TrBr} \\
28-6\end{array}$} & \multirow{3}{*}{$\begin{array}{l}\text { WPk1 } \\
28-6\end{array}$} & \multirow{3}{*}{$\begin{array}{l}\text { Wtml } \\
28-6\end{array}$} \\
\hline & & & & & & & & & & & \\
\hline & \multicolumn{2}{|c|}{ IG TS } & & & & & & & & & \\
\hline \multicolumn{12}{|l|}{ Arthropoda } \\
\hline \multicolumn{12}{|l|}{ Hexapoda } \\
\hline \multirow{2}{*}{\multicolumn{12}{|c|}{$\begin{array}{l}\text { Insecta } \\
\text { Hemiptera }\end{array}$}} \\
\hline & & & & & & & & & & & \\
\hline \multicolumn{12}{|l|}{ Corixidae } \\
\hline Cymatia & & 6 & & & & & & & & & 1 \\
\hline Micronecta & & 6 & & & & & & & & 2 & \\
\hline Sigara & & 5 & & & & & & & 94 & & \\
\hline \multicolumn{12}{|l|}{ Naucoridae } \\
\hline Ilyocoris & & 5 & & & 1 & & & & & & \\
\hline \multicolumn{12}{|l|}{ Notonectidae } \\
\hline Notonecta & & 5 & & & 1 & & & & 2 & & \\
\hline Lepidoptera & & & & & & & & & & 1 & \\
\hline \multirow{2}{*}{\multicolumn{12}{|c|}{$\begin{array}{l}\text { Megaloptera } \\
\text { Sialidae }\end{array}$}} \\
\hline & & & & & & & & & & & \\
\hline Sialis & & 5 & & & & & & 1 & 1 & & 15 \\
\hline \multicolumn{12}{|l|}{ Odonata } \\
\hline \multicolumn{12}{|l|}{ Calopterygidae } \\
\hline Calopteryx & & 8 & & & & & & 2 & & & \\
\hline \multicolumn{12}{|l|}{$\underline{\text { Coenagrionidae }}$} \\
\hline Ischnura & & 6 & & & & & & & 2 & 2 & \\
\hline \multicolumn{12}{|l|}{$\underline{\text { Lestidae }}$} \\
\hline Lestes & & 7 & & & & & & & & & $5^{*}$ \\
\hline \multicolumn{12}{|l|}{ Trichoptera } \\
\hline Ecnomidae & & 6 & & $1^{*}$ & & & & & & & \\
\hline Hydropsychidae & 3 & 6 & & & 9 & & & A & & & \\
\hline Hydroptilidae & 5 & 8 & & & & & & & & 38 & 3 \\
\hline Leptoceridae & 4 & 8 & & & 2 & & & & & & \\
\hline$\underline{\text { Limnephilidae }}$ & 3 & 8 & & & & & & 1 & & & \\
\hline Phryganeidae & & 9 & & & & & & & & & $1^{*}$ \\
\hline Polycentropodidae & 4 & 6 & & & & & & & & & $2 * / 1$ \\
\hline Psychomyiidae & 4 & 7 & & & 17 & & & & & & \\
\hline
\end{tabular}

